UNIVERSIDADE DE BRASÍLIA - UNB

INSTITUTO DE GEOCIÊNCIAS - IG

ESTUDO DE ROCHAS EXÓTICAS DA FORMAÇÃO SOPABRUMADINHO E POSSÍVEIS IMPLICAÇÕES PARA A FONTE DOS DIAMANTES DO ESPINHAÇO MERIDIONAL

Francisco Edson Bezerra Neto

BRASÍLIA, Outubro 2016. 


\title{
ESTUDO DE ROCHAS EXÓTICAS DA FORMAÇÃO SOPA- BRUMADINHO E POSSÍVEIS IMPLICAÇÕES PARA A FONTE DOS DIAMANTES DO ESPINHAÇO MERIDIONAL
}

\author{
Francisco Edson Bezerra Neto
}

Dissertação de Mestrado N $^{0} 381$

BANCA EXAMINADORA

Prof. Dr. José Eloi Guimarães Campos (Orientador)

Prof. Dr. Claudinei Gouveia de Oliveira (UnB)

Prof. Dr. Francisco Valdir Silveira (CPRM)

BRASÍLIA, Outubro 2016. 


\section{AGRADECIMENTOS}

Agradeço primeiramente à minha família e a minha companheira, que sempre me apoiam em minhas decisões e me guiam no melhor caminho. Agradeço também ao meu orientador, pessoa ímpar em conhecimento e caráter. Aos meus grandes amigos da CPRM, em especial ao Valdir e a Lys, pessoas as quais possuo imenso carinho e tive o prazer de estagiar no Projeto Diamante Brasil, sem o qual este trabalho não seria possível. Agradeço ao meu amigo Rafael Coxa, pela prontidão em ajudar.

Enfim, agradeço à Deus, que nos permite conquistar com saúde e determinação nossos sonhos.

Em relação aos filitos hematíticos, que me encantaram com seu mistério, gostaria de relembrar este pequeno trecho musical:

“Eu prefiro ser esta metamorfose ambulante, do que ter aquela velha opinião formada sobre tudo.” 


\section{RESUMO}

A Serra do Espinhaço Meridional está localizada na porção sudeste do Cráton do São Francisco e amalgama-se com a Faixa Araçuaí à nordeste. A evolução tectônica compreende por evento extensional com desenvolvimento de rifte em $1.7 \mathrm{Ga}$ e inversão tectônica durante o evento orogenético brasiliano. Dentre as diversas lacunas do conhecimento relacionadas com a evolução geológica do Espinhaço, destacam-se as incertezas sobre a origem dos diamantes da região, objeto do presente estudo. O diamante ocorre em metaconglomerados/metabrechas da Formação Sopa Brumadinho, assim como em crostas lateríticas, material coluvionar e aluvionar. Em relação à origem dos diamantes da região são propostas por diferentes autores duas linhas de pensamentos: (i) a rocha fonte encontra-se à oeste no Cráton do São Francisco sob coberturas neoproterozoicas; (ii) a rocha fonte está localizada no interior da bacia Espinhaço. Uma rocha exótica, composta basicamente por sericita/muscovita e óxidos de Fe/Ti, denominada filito hematítico, já foi proposta como rocha fonte dos diamantes. Esta rocha mostra-se intensamente modificada por processos metamórficos/metassomáticos, sua natureza ígnea é indiscutível mesmo que sua geoquímica não possua equivalente moderno. Em campo, existe relação direta do filito hematítico com as áreas de garimpo diamantífero, aflorando preferencialmente à oeste das áreas mineradas. Outra fonte de diamantes consiste no "gorgulho", material laterítico proveniente, principalmente, a partir da alteração do filito hematítico. Vestígios de atividade garimpeira sobre o filito hematítico são recorrentes na área de estudo, com destaque para o Povoado de Macacos, local em que não há ocorrência de metaconglomerado/metabrecha, sendo a lavra realizada exclusivamente a partir da extração do filito. Resultados geoquímicos forneceram resultados semelhantes com os já citados na literatura, ressaltando homogeneidade de sua composição química, independente das diferenças geográficas ou texturais. Análises U-Pb de zircões recuperados dos filitos hematíticos forneceram idade de $1.736 \mathrm{Ma}$. O filito hematítico pode ser interpretado como a rocha fonte primária dos diamantes, sendo classificado em função de suas características petrográficas como possível metalamproíto.

Palavras-Chave: Serra do Espinhaço Meridional, Filito Hematítico, Diamante, Metalamproíto. 


\begin{abstract}
The Southern Espinhaço Ridge is located in the southeast boundary of the São Francisco Craton, and amalgamates northeastern with the Araçuaí Belt. It consists predominantly of quartzite from the Espinhaço Supergroup. The tectonic evolution of the region starts with an extensional event that resulted in fragmentation and development of a rift basin where the Espinhaço Supergroup was deposited about $1.7 \mathrm{Ga}$. The last tectonic event is a tectonic inversion during the Brasiliano orogeny in the Neoproterozoic. The Sopa Brumadinho Formation (Espinhaço Supergroup) shows diamonds occurrences in metaconglomerate/metabreccia lithofacies, lateritic crust, colluvial and alluvial materials. However the diamonds source rocks are still an open debate. There are two main hypothesis for the location of the source rock: to some authors the sources is considered from west Sao Francisco Craton (under neoproterozoic sediments); and for other the sources is inside the sedimentary basin. An uncommon rock, composed by sericite/muscovite and $\mathrm{Fe} / \mathrm{Ti}$ oxides, denominated hematite phyllite had been proposed as the rock source of the diamonds. The hematite phyllite has an igneous protolith even without a modern geochemical equivalent. The field relations indicate the occurrence of the hematite phyllite outcrops west to mining extraction places called "garimpos", in special in the Macacos Town where the metaconglomerates does not occurs and the diamonds extraction is directly from the hematite phyllite. Secondary mining target are the weathered phyllite, a lateritic crust locally called "gorgulho" also indicate the relationship between the sources of diamonds with the hematite phyllite. The geochemistry analyses are consistent to the literature, and the results show a homogeneous chemical composition for different geographic and textural conditions. The zircons $\mathrm{U}-\mathrm{Pb}$ analyses result an age around 1.736 Ma. Therefore the hematite phyllite can be interpreted as the primary source rock of the diamonds, classified due to the magmatism and absence of kimberlitic minerals as a possible metalamproite source.
\end{abstract}

Keywords: Southern Espinhaço Range, Hematite Phyllite, Diamond, Metalamproite. 


\section{SUMÁRIO}

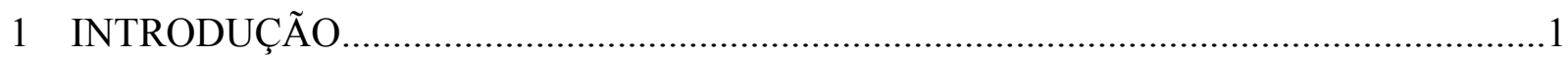

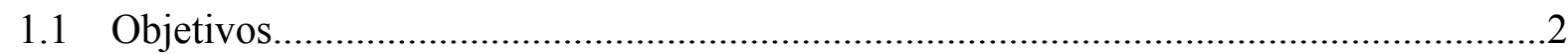

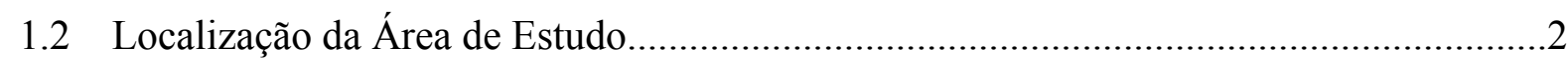

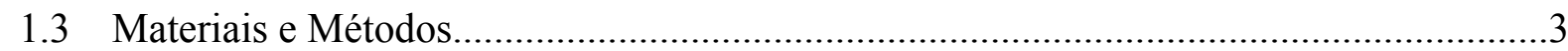

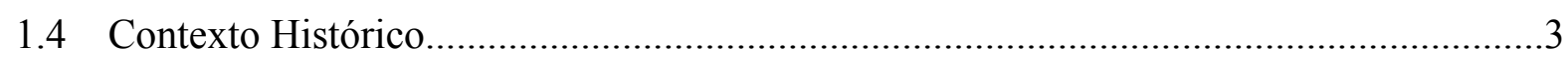

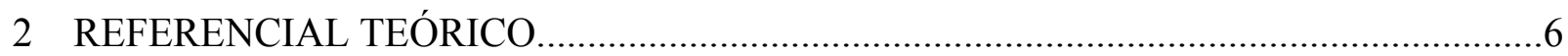

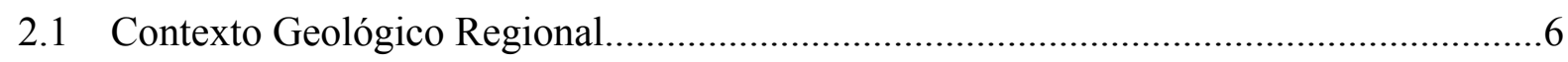

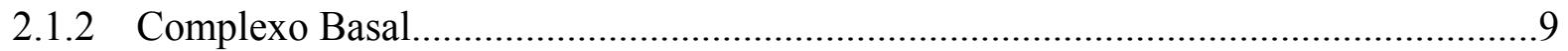

2.1.3 Supergrupo Rio Paraúna....................................................................................

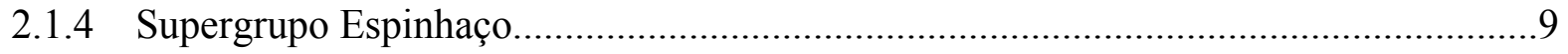

2.1.4.1 Grupo Guinda....................................................................................... 10

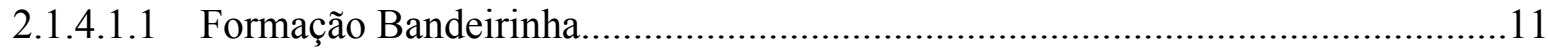

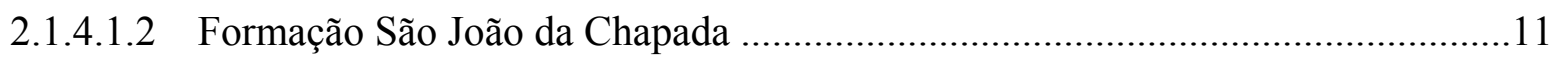

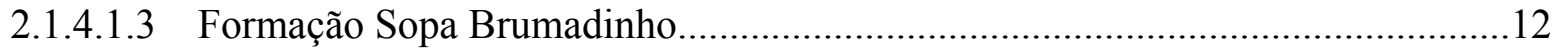

2.1.4.1.4 Formação Galho do Miguel...........................................................................13

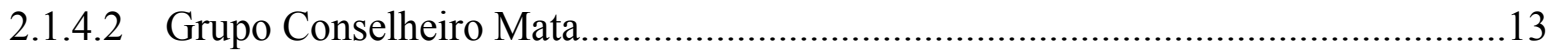

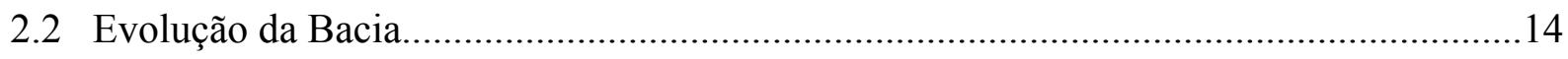

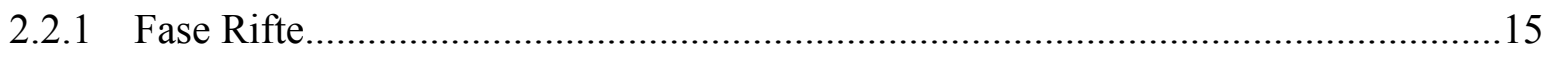

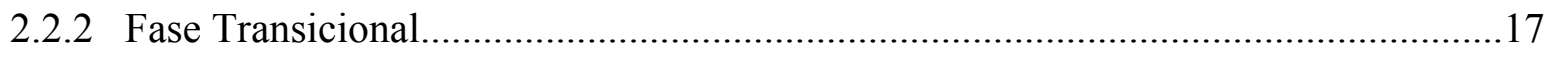

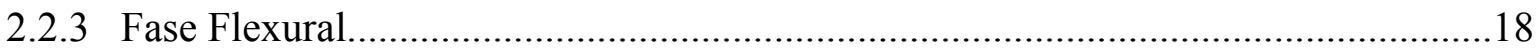

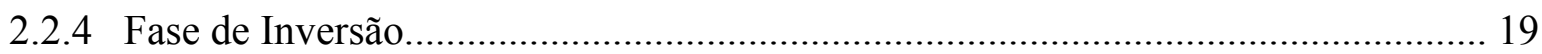

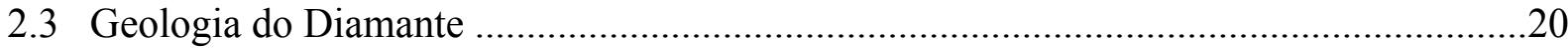

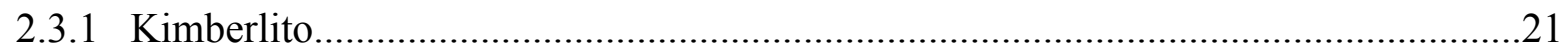

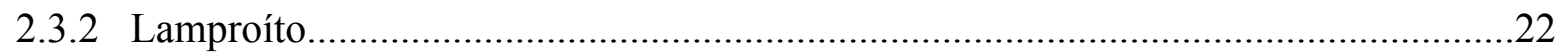

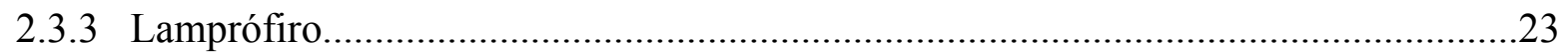

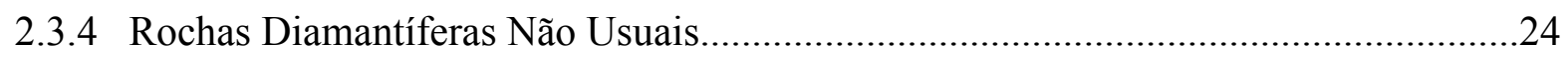

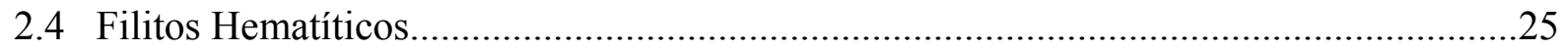

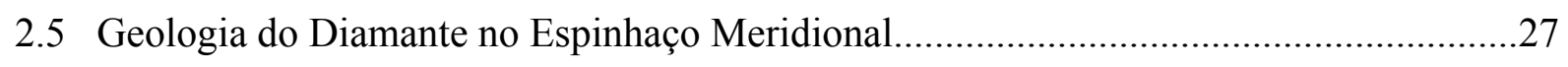

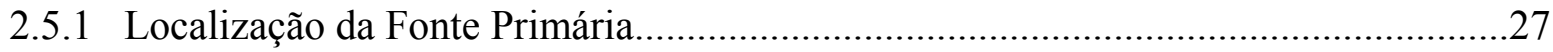




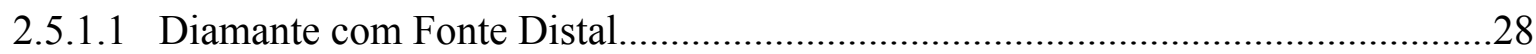

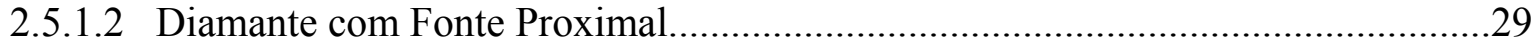

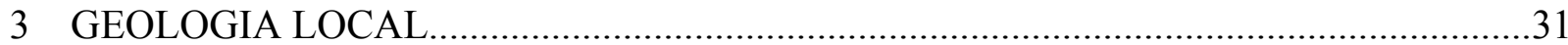

3.1 Ocorrências de Diamantes na Serra do Espinhaço Meridional........................................32

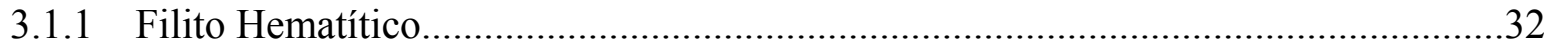

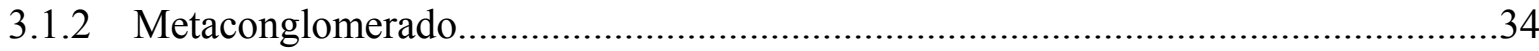

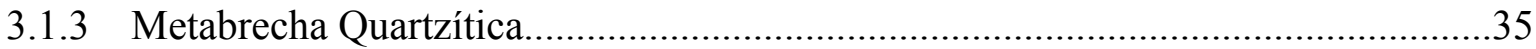

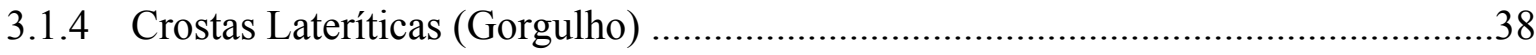

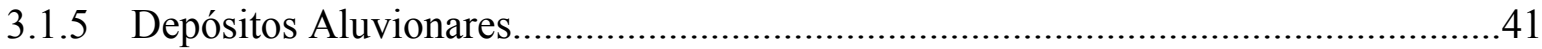

3.2 Campos Diamantíferos Objetos do Presente Estudo...................................................41

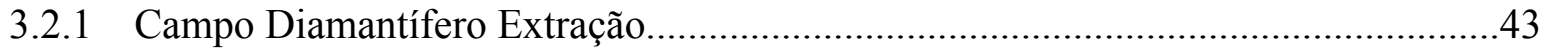

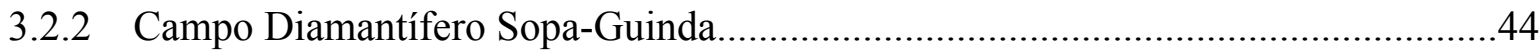

3.2.3 Campo Diamantífero de São João da Chapada........................................................55

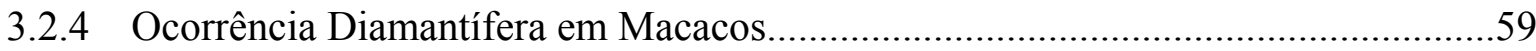

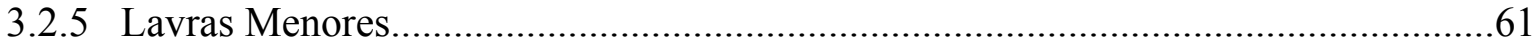

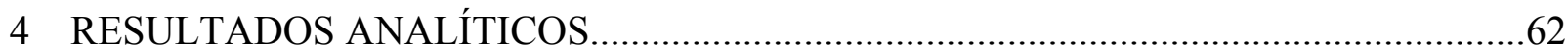

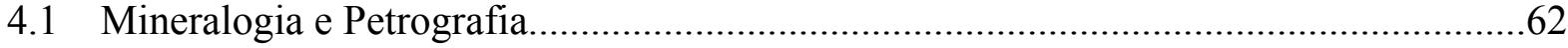

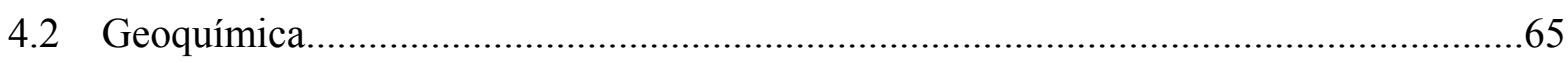

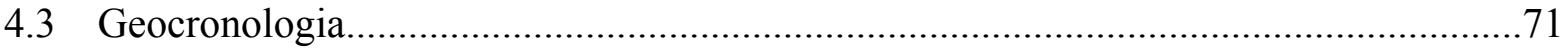

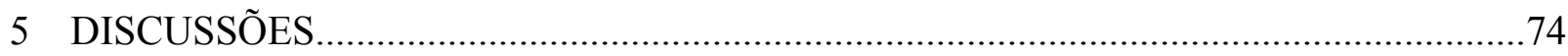

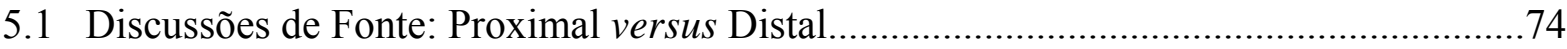

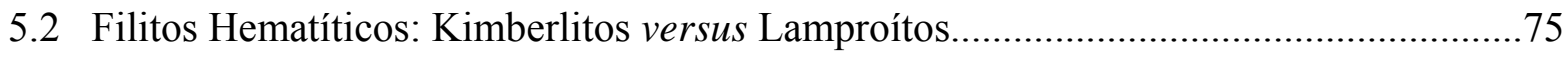

5.3 Características dos Diamantes da Serra do Espinhaço Meridional..................................76

5.4 Relação Entre Filitos Hematíticos e Fonte dos Diamantes..............................................80

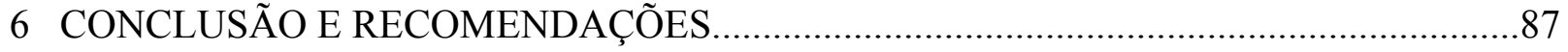

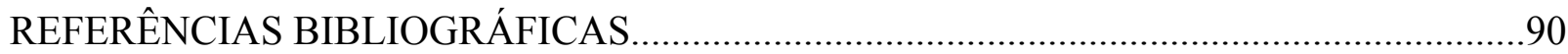

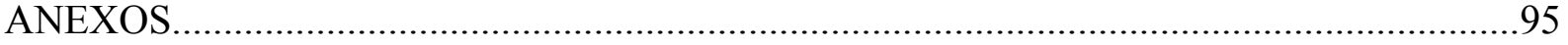




\section{ÍNDICE DE FIGURAS}

Figura 1.1 - Mapa de acesso para Diamantina partir de Brasília e Belo Horizonte (Fonte: Google Earth..3

Figura 2.1 - Limites aproximados do Cráton do São Francisco destacando a Serra do Espinhaço. SdEM:

Serra do Espinhaço Meridional, SdES: Serra do Espinhaço Setentrional (modificado de Chaves, 1997)....6

Figura 2.2 - Mapa geológico da área, de acordo com Projeto Espinhaço realizado por CODEMIG/CPRM/

Governo de Minas.

Figura 2.3- Coluna Estratigráfica do Supergrupo Espinhaço, adaptada de Schöll \& Fogaça (1979).........10

Figura 3.1 - Carta estratigráfica da Formação Sopa Brumadinho destacando as unidades diamantíferas:

Metaconglomerados, filitos hematíticos e metabrecha quartzítica...... .31

Figura 3.2 - Filito sericítico com brilho e coloração característicos. ........................................................32

Figura 3.3 - Filito sericítico exibindo crenulação característica de filito de origem sedimentar.................32

Figura 3.4 - Filito hematítico com manchas derivadas da alteração diferencial. .......................................33

Figura 3.5 - Filito hematítico com paseudormorfos sericitizados. .............................................................33

Figura 3.6 - Filito hematítico com ausência de concentrações de óxidos. .................................................33

Figura 3.7 - Filito hematítico com níveis de sericita intercalados com níveis de óxidos...........................33

Figura 3.8 - Filito hematítico exibindo nódulos centimétricos de óxido de ferro e turmalina. ...................33

Figura 3.9 - Filito hematítico em elevado grau de alteração apresentando coloração rosada. ....................33

Figura 3.10 - Metaconglomerado litificado localizada na lavra Lavrinha, próximo ao povoado Guinda..34

Figura 3.11 - Detalhe da metabrecha quartzítica com fragmento anguloso de quartzito no centro............36

Figura 3.12 - Zonas de maior deformação localizadas no interior da metabrecha quartzítica. ..................36

Figura 3.13 - Fragmento subarredondado de quartzito envolto matriz pelítica.........................................37

Figura 3.14 - Metabrecha quartzítica exibindo fragmentos estirados de quartzito.....................................37

Figura 3.15 - Fragmento de filito no interior da metabrecha quartzítica, imediatamente acima aflora o

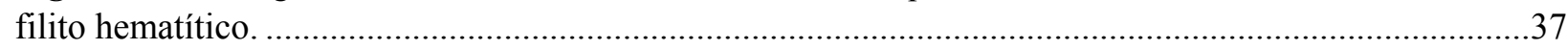

Figura 3.16 - Alteração diferencial de quartzito inserido na metabrecha quartzítica/filito hematítico......37

Figura 3.17 - Metabrecha quartzítica litificada aflorante na lavra Colônia. .............................................38

Figura 3.18- Detalhe para o filito hematítico que compõe a matriz da metabrecha quartzítica aflorante na

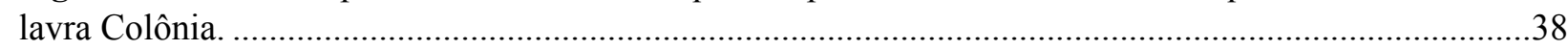

Figura 3.19 - Perfil de alteração do filito hematítico na lavra Caldeirões.....................................................38

Figura 3.20 - Perfil de alteração do filito hematítico no Povoado Sopa......................................................38

Figura 3.21 - Imagem de satélite ilustrando ocorrência de filito hematítico e gorgulho, desde a lavra

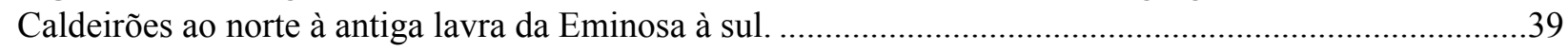

Figuras 3.22 e 3.23 - Amontoados de gorgulho tratados para recuperação de diamantes...........................39

Figura 3.24 - Foto panorâmica da abundante concentração de gorgulho lavrado.......................................39

Figuras 3.25 e 3.26 - Antiga estação de lavra do gorgulho, localizada próxima à lavra Eminosa..............40

Figura 3.27 - Amostra do gorgulho evidenciando as principais características da rocha, destaque para seu

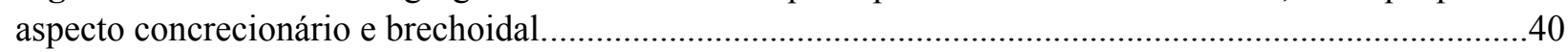

Figura 3.28- Imagem ilustrando as principais lavras visitadas neste trabalho (Fonte: Google Earth).......42 Figura 3.29 - Afloramento de filito hematítico na lavra Cavalo Morto. ....................................................43 
Figura 3.30 - Blocos de filito hematítico situados nas adjacências da lavra, rocha cinza com pseudomorfos sericitizados.

Figura 3.31 - Afloramento de cristas verticalizadas de filito hematítico na lavra Perpétua......................44

Figura 3.32 - Filito sericítico aflorante na lavra Perpétua, visivelmente distinto do filito hematítico. .....44

Figura 3.33 - Amostra de filito hematítico da lavra Perpétua, rocha de cor cinza com eventuais concentrações de óxidos.

Figura 3.34 - Amostra de filito de com feições que se assemelham ao filito sericítico. . .45

Figura 3.35 - Vista geral da lavra Barro Branco. .45

Figura 3.36 - Metaconglomerado friável, local de lavra recente na lavra Barro Branco.

Figura 3.37 - Filito hematítico com textura brechoidal exibindo pseudomorfos tabulares. .46

Figura 3.38 - Amostra de filito hematítico de coloração avermelhada devido à alteração intempérica.....46

Figuras 3.39 e 3.40 - Filito hematítico exposto na região da lavra Lavrinha, rocha escura com porções sericitizadas apresentando textura brechoidal. .46

Figura 3.41 - Filito hematítico em elevado grau de alteração intempérica, lavra Lavrinha.

Figura 3.42 - Ocorrência de filito sericítico, rocha com brilho e crenulações características.

Figura 3.43 - Vista geral da lavra Brumadinho.

Figura 3.44 - Filito hematítico aflorando como cristas verticalizadas na lavra Brumadinho.

Figura 3.45 - Concentrado de garimpo sobre o filito hematítico, localizado na lavra Brumadinho. .........48

Figura 3.46 - Detalhe do filito hematítico destacando seu aspecto heterogêneo...........................................48

Figura 3.47 - Amostra de filito hematítico ocorrente da lavra Brumadinho.

Figura 3.48 - Amostra de filito hematítico de coloração arroxeada, localizado em canal ao sul da lavra Brumadinho.

Figura 3.49 - Amostra do filito hematítico presente na lavra Diamante Vermelho. .48

Figura 3.50 - Afloramentos do filito hematítico ocorrendo na forma de cristas verticalizadas. . .49

Figura 3.51 - Intercalação de quartzito, metaconglomerado e filito na lavra Colônia.

Figura 3.52 - Abundância de filitos no rejeito da atividade garimpeira nas adjacências da lavra Colônia.

Figura 3.53 - Fragmento anguloso de filito hematítico no metaconglomerado............................................50

Figura 3.54 - Amostra do filito hematítico presente na lavra Colônia. ......................................................50

Figura 3.55 - Amostra de filito sericítico, aflorante na lavra Colônia.......................................................50

Figura 3.56 - Vista geral da lavra Bambá, local com abundante material arenoso. ..................................51

Figura 3.57 - Área de garimpo a partir do filito hematítico alterado. ........................................................51

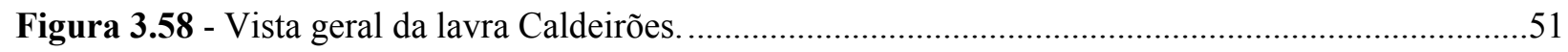

Figura 3.59 - Interior da lavra Caldeirões com destaque para ocorrência de filito hematítico e material

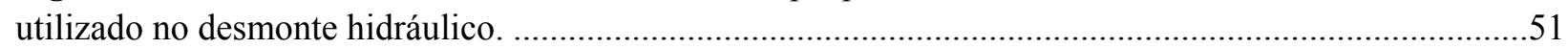

Figura 3.60 - Variedades de texturas de filito hematítico presentes no interior da lavra Caldeirões.........52

Figura 3.61 - Detalhe de bloco de filito hematítico em estágio inicial de alteração, adquirindo a tonalidade rosada.

Figura 3.62 - Fragmento anguloso de filito hematítico em metaconglomerado localizado na lavra Caldeirões. . .52

Figura 3.63 - Contato do metaconglomerado com filito hematítico. 
Figura 3.64 - Filito hematítico rico em magnetita euhédrica, ocorrente na lavra Caldeirões.

Figura 3.65 - Filito hematítico esverdeado devido à ocorrência de clorita. Ocorrem também pseudomorfos brancos, lavra Caldeirões.

Figuras 3.66 - Vista geral da lavra Eminosa, paredes das lavras são compostos por filito hematítico. ......53

Figura 3.67 - Fragmentos de filito hematítico friável.

Figura 3.68 - Amostra do filito hematítico alterado.

Figura 3.69 - Amostra de filito hematítico menos alterado. .54

Figura 3.70 - Afloramento de filito hematítico na lavra Damásio. .54

Figura 3.71 - Detalhe do filito hematítico. .54

Figura 3.72 - Dique de filito hematítico cortando quartzitos na lavra Damásio. .55

Figura 3.73 - Amostra de filito hematítico ocorrentes com heterogeneidades rosadas. .55

Figura 3.74 - Clastos angulosos de filito hematítico presentes no metaconglomerado. .55

Figura 3.75 - Vista geral das lavras, Duro à frente e Barro ao fundo...... .56

Figura 3.76 - Filito hematítico intercalado com níveis de metabrecha quartzítica...............................56

Figura 3.77 - Metabrecha quartzítica com fragmentos de quartzo e filito. .........................................56

Figura 3.78 - Amostra do filito hematítico alterado, adquirindo coloração característica. .......................56

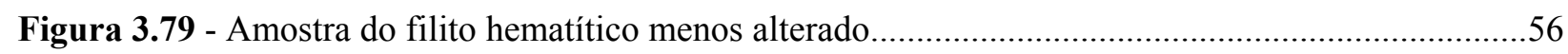

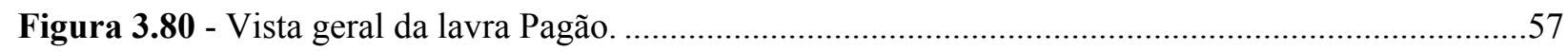

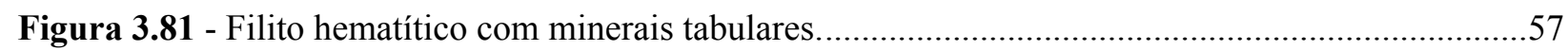

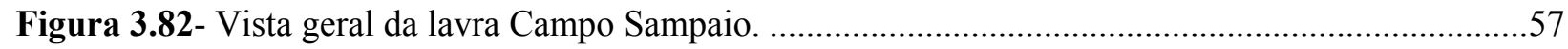

Figura 3.83- Pequeno morro localizado na porção central da lavra, local em que aflora o filito hematítico.

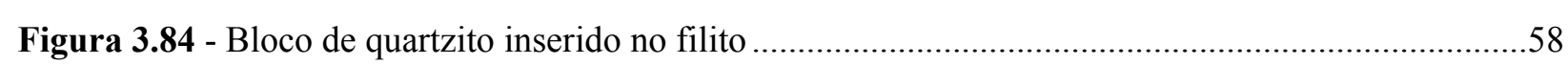

Figura 3.85 - Amostra do filito hematítico e suas heterogeneidades. .................................................58

Figura 3.86 - Aparência geral do filito hematítico com textura brechada............................................59

Figura 3.87 - Blocos de filitos localizados nas proximidades do povoado de Macacos. .........................60

Figura 3.88 - Afloramento de filito hematítico em antigo local de lavra..........................................60

Figura 3.89 - Amostra do filito hematítico que ocorre no povoado Macacos.....................................60

Figuras 3.90 a 3.93 - Lavras menores próximas ao povoado Sopa. O filito hematítico aflora em todos os locais, com diferentes texturas e graus de intemperismo.

Figura 4.1 - Lâmina de filito hematítico da lavra Brumadinho, textura equigranular composta por cristais de sericita e óxidos...

Figura 4.2 - Lâmina de filito hematítico localizado nas proximidades do povoado Sopa, textura equigranular.

Figura 4.3 - Lâmina de filito da lavra Campo Sampaio exibindo cristal estirado de sericita com sobreposição de óxidos.

Figura 4.4 - Lâmina de filito da lavra Brumadinho indicando a existência de duas gerações de muscovita na porção superior da lâmina......

Figura 4.5 - Lâmina de amostra da lavra próxima ao Povoado Macacos, motrando fenocristal sericitizado com turmalina em seu interior.. 
Figura 4.6 - Lâmina de filito de amostra da lavra Brumadinho, matriz sericítica com cristais maiores de óxidos.

Figura 4.7 - Lâmina de filito hematítico de rocha coletada localizado ao Povoado Macacos, rocha sem foliação.

Figura 4.8 - Lâmina de filito hematítico localizado próximo ao Povoado Sopa, destaque para a foliação proeminente.

Figura 4.9 - Lâmina de filito hematítico da lavra Brumadinho, matriz rica em sericita com microdobras.

Figura 4.10 - Lâmina de filito hematítico da lavra Caldeirões, composta por clorita, óxidos e sericita....64

Figura 4.11 - Seção delgada de amostra de filito da Lavra Campo Sampaio indicando a textura brechada da rocha. 65

Figura 4.12 - Lâmina de amostra de filito hematítico da lavra Campo Sampaio com textura porfirítica..65

Figura 4.13 - Diagrama isotópico U-Pb de amostra de filito hematítico presente na lavra Brumadinho...72

Figura 4.14 - Diagrama isotópico U-Pb de filito hematítico presente na lavra Eminosa.........................72

Figura 4.15 - Diagrama isotópico U-Pb do filito hematítico presente na lavra Campo Sampaio..............73

Figura 5.1 - Local de lavra em que diamantes foram recuperados..................................................78

Figura 5.2 - Bica de sluicer utilizada na recuperação dos diamantes.................................................78

Figuras 5.3 e 5.4 - Detalhes diamante 01 com arestas sem sinais de abrasão........................................79

Figuras 5.5 e 5.6 - Detalhes diamante 02, tetrahexaedróide achatado .................................................79

Figuras 5.7 e 5.8 - Detalhes diamante 03, com marcas de percussão e spots verdes. ..............................79

Figuras 5.9 e 5.10 - Detalhes de exemplos de diamante com feições de transporte sedimentar (marcas de

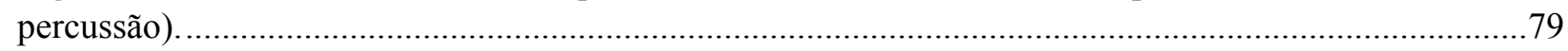

Figura 5.11 - Local de atividade garimpeira sobre o filito hematítico na lavra Caldeirões. ....................82

Figura 5.12 - Atividade garimpeira sobre o filito hematítico na lavra Barro.....................................82

Figura 5.13 - Local de atividade garimpeira sobre o filito hematítico na Lavra Brumadinho. .................82

Figura 5.14 - Ilustração esquemática explicando o ciclo do diamante na região da Serra do Espinhaço Meridional

Figura 5.15 - Modelo ilustrando intrusão dos corpos correspondentes ao filito hematítico e relação com a metabrecha e metaconglomerado. 


\section{ÍNDICE DE TABELAS}

Tabela 2.1 - Estratigrafia do Supergrupo Espinhaço de acordo com Pflug (1968), Scholl \& Fogaça (1979) e Almeida Abreu \& Pflug (1994), adaptado de Almeida Abreu (1996)...................................................14

Tabela 2.2 - Autores e respectivas hipóteses sobre a origem dos diamantes..............................................28

Tabela 2.3 - Resumo dos argumentos para fonte distal e proximal dos diamantes da região do Espinhaço

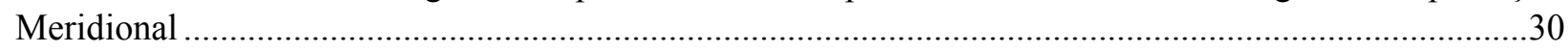

Tabela 4.3- Composição do filito hematítico padrão segundo Knauer e Schrank (1993).........................65

Tabela 4.4 - Resultados geoquímicos de filitos hematíticos analisados neste trabalho. Elementos maiores

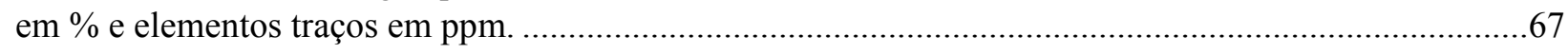

Tabela 4.5 - Comparativo dos resultados geoquímicos médios de filitos hematíticos por diferentes autores. 68

Tabela 4.6 - Resultados de análises em microssonda eletrônica de silicatos (tabela superior) e óxidos (tabela inferior). . .70 


\section{CAPÍTULO 1}

\section{INTRODUÇÃO}

A Serra do Espinhaço Meridional constitui alvo recorrente de diversos estudos, sobretudo devido à expressiva ocorrência de diamantes. Sua evolução possui contexto geológico complexo composto por processos de rifteamento, sedimentação em meio-grábens associada a magmatismo, metamorfismo e inversão tectônica em ambiente compressional. Apesar do volume de informações disponíveis, incógnitas ainda instigam estudos científicos, dos quais se destaca a polêmica origem dos diamantes da região, até o momento, indefinida.

Para melhor compreensão da importância histórica e econômica da ocorrência diamantífera nesta porção da serra, os primeiros diamantes do mundo recuperados a partir de rocha compacta não sucederam em fonte kimberlítica, mas sim em rochas metassedimentares localizadas nas proximidades de Diamantina, Serra do Espinhaço Meridional.

Atualmente, conflitos de ideias não somente quanto à origem da rocha primária dos diamantes, mas também quanto a sua localização, interna ou externa à Bacia do Espinhaço, geram debates entre pesquisadores. Deste modo, caso as fontes fossem externas à bacia, esta estariam localizadas à oeste, intrudidas no Cráton do São Francisco e recobertas pelos grupos Bambuí e Macaúbas e, desta maneira, dificilmente seriam identificadas. Contudo, admitindo fonte primária interna à bacia os diamantes teriam carácter proximal aos metaconglomerados proterozoicos da Formação Sopa Brumadinho, o que facilitaria o reconhecimento da suposta fonte.

Coincidente com as atuais incertezas, as rochas denominadas filitos hematíticos, já descritas como diamantíferas afloram na Serra do Espinhaço Meridional. São rochas recorrentes, abrangendo variações faciológicas e variações de composição geoquímica de difícil caracterização, uma vez que o metamorfismo regional promoveu recristalização de sua assembleia mineralógica original, resultando em uma rocha composta basicamente por sericita/muscovita e óxidos de Fe/Ti. Por conseguinte, os filitos hematíticos apresentam controvérsias não somente quanto a sua origem, mas também quanto ao ambiente no qual foi gerado e seu significado dentro do contexto geológico regional.

Ainda que centenas de rochas de afinidade kimberlítica tenham sido descobertas no Brasil durante as últimas décadas, a produção de diamantes ocorre quase que exclusivamente a partir de fontes secundárias, de forma que em muitas ocorrências as fontes primárias permanecem desconhecidas e dentre as descobertas poucas são economicamente viáveis. Tais circunstâncias contrastam com a produção de outros países, tais como África do Sul, Austrália, Botswana e 
Rússia. Desta forma, o Brasil necessita de fontes primárias economicamente viáveis para assim voltar a ocupar posições de maior destaque no cenário internacional.

\section{1 - Objetivos}

O presente trabalho se propõe à estudar e caracterizar os filitos hematíticos, rochas ígneas intrusivas recorrentes na Serra do Espinhaço Meridional, sobretudo em áreas de lavra diamantífera. Dessa forma, este trabalho discorre sobre os estudos existentes envolvendo tais rochas e, consequentemente, acrescenta novas informações. Ao particularizar os filitos hematíticos objetivase determinar qual a provável natureza do magma predecessor do filito hematítico, sua relação com as demais unidades diamantíferas e sua peculiaridade potencial como rocha fonte dos diamantes.

Com o objetivo de direcionar a caracterização dos filitos hematíticos áreas renomadas de garimpos foram visitadas e, por conseguinte, diversas lavras de menor porte, sempre com o intuito de investigar a ocorrência dos filitos hematíticos e estabelecer possíveis correlações geológicas com o diamante assim como com demais unidades diamantíferas. Dentre os campos diamantíferos circunscritos no distrito diamantífero de Diamantina, o campo Sopa-Guinda merece destaque devido à elevada concentração de áreas de lavra, mesmo que em sua maioria atualmente desativadas.

\section{2 - Localização da Área de Estudo}

Após o reconhecimento de diamantes na Serra do Espinhaço Meridional, em particular na extensão do Rio Jequitinhonha, intensa atividade de mineração foi instalada na região. A cidade de Diamantina consiste no principal centro urbano, deste modo, desenvolveu-se a partir do processo histórico de produção de diamantes.

A cidade de Diamantina está localizada na porção centro-norte de Minas Gerais, distando 300 km da capital estadual Belo Horizonte e 750 km de Brasília (Figura 1.1). Abundantes áreas de garimpo ocorrem em sua adjacência. $\mathrm{O}$ foco deste trabalho concentra-se na região oeste-noroeste de Diamantina, local denominado campo diamantífero Sopa-Guinda, local de notória importância histórica em função da quantidade de lavras existentes. 


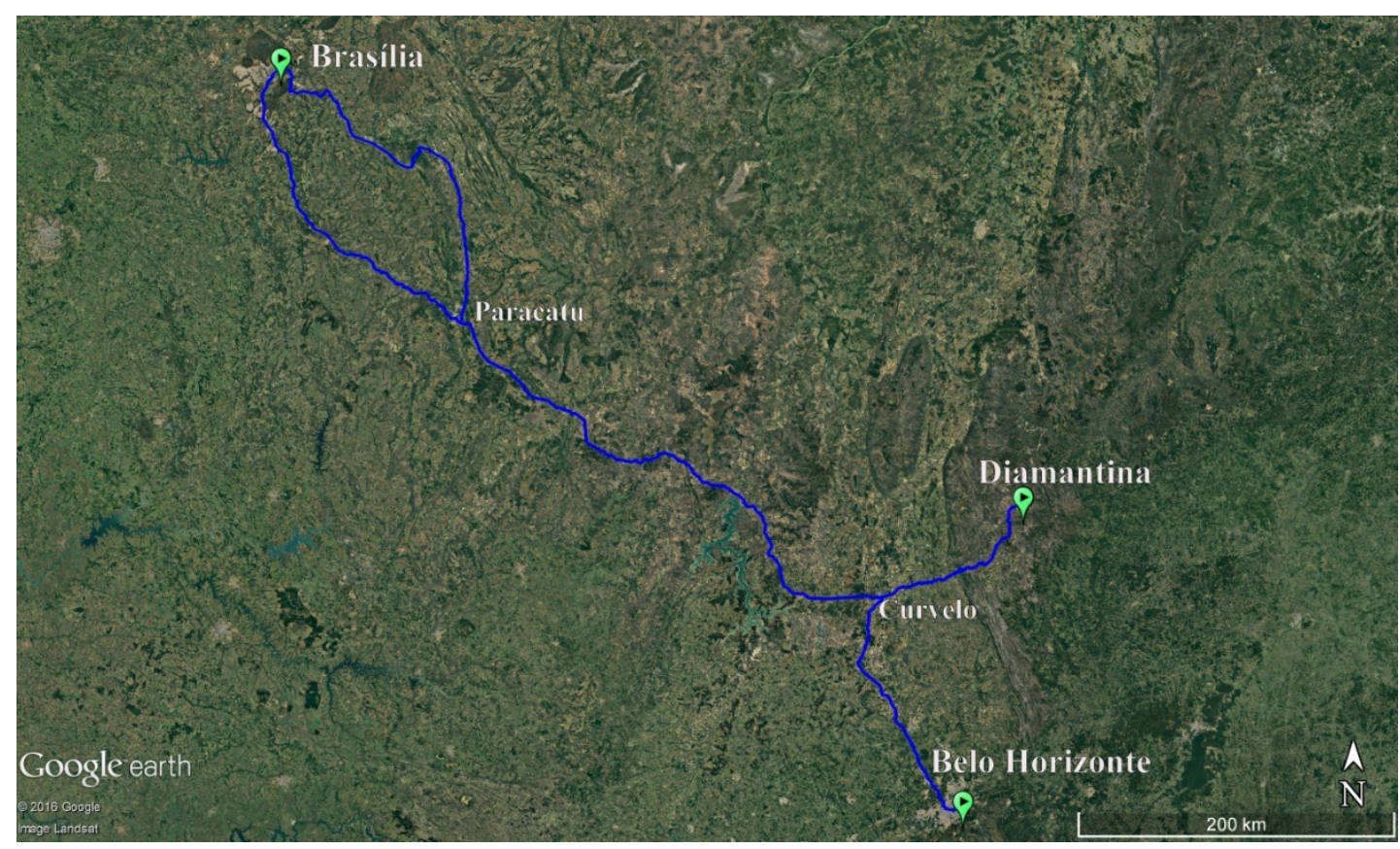

Figura 1.1 - Mapa de acesso para Diamantina partir de Brasília e Belo Horizonte (Fonte: Google Earth).

\section{3 - Materiais e Métodos}

Este trabalho foi efetuado a partir de métodos tradicionais de campo, abrangendo descrição de fácies, observação do empilhamento estratigráfico e correspondências entre as ocorrências dos filitos hematíticos com as áreas de lavra. Métodos analíticos forneceram subsídios ao presente estudo, incluindo petrografia, geoquímica, geocronologia e difração de raios X.

A análise de informações da literatura constatou ausência de trabalhos recentes que abordam a controvérsia existente, não somente em referência aos filitos hematíticos, mas também com relação às demais unidades diamantíferas. Desta forma, procurou-se ilustrar explicitamente as litologias diamantíferas, sempre ressaltando os filitos hematíticos. Informações contidas na literatura foram evidenciadas e relacionadas com os novos dados obtidos.

As etapas de campo foram realizadas em 4 campanhas, por vezes revisitando determinados locais com o propósito de reforçar o entendimento geológico. Ao todo, 15 lavras históricas foram visitadas, tal como diversas lavras de menor porte e exposições consideradas clássicas das formações basais do Supergrupo Espinhaço.

\section{4 - Contexto Histórico}

Diamantina possui sua história fundamentada na exploração de diamantes em suas imediações, constituindo-se um marco histórico da mineração brasileira e impulsionando o Brasil 
como maior produtor mundial de diamantes. Principal centro urbano da época, Arraial do Tijuco e atual Diamantina, foi fundado em 1713 por bandeirantes que garimpavam ouro, porém não foi a mineração de ouro, mas sim a de diamante que marcou a história da região. A descoberta de diamantes despertou interesse da Coroa Portuguesa, que estipulou legislação a fim de regulamentar sua exploração, o que foi em parte ineficaz devido à resistência dos mineradores e o fato dos diamantes possuírem pequenas dimensões com alto valor agregado, facilitando desta forma o contrabando. Em 1735, visto a ineficiência da legislação imposta pela Intendência dos Diamantes, a coroa proibiu a extração de diamantes durante cinco anos até constituir maneira mais eficiente de controle e, principalmente, aguardar a recuperação dos preços internacionais do quilate, abalado pela abundância de oferta. Entre 1740 e 1771 perdurou o sistema de arrematação por contratos e, a partir de tal período, foi criada a Real Extração, submetida diretamente à Coroa e que permaneceu até 1832.

No presente momento, o foco de atividade garimpeira concentra-se nas margens do Rio Jequitinhonha, local denominado Areinha e antigo trecho de exploração da Mineração Rio Novo, que extraiu diamantes por duas décadas e finalizou atividade em 2007 alegando que o empreendimento não era mais economicamente viável. Tal atividade influencia a economia da cidade e absorve mão de obra, visto que uma quantidade considerável de gemas é extraída.

A ocorrência diamantífera é atribuída à presença de rochas metassedimentares mineralizadas, particularmente metaconglomerados. Local de atividade mineradora desde o século XVII, a paisagem encontra-se profundamente antropizada, uma vez que não foram adotados os cuidados ambientais apropriados. Nas proximidades de Diamantina, diversos povoados foram estabelecidos devido a ocorrência diamantífera, tornando-se pequenos centros comerciais e culturais. O cenário socioeconômico atual contrasta com o antes vivenciado, uma vez que a população exibe níveis elevados de pobreza, sobretudo devido ao fato da atividade garimpeira encontrar-se fortemente restrita por autoridades ambientais, restando essencialmente pequenos garimpos manuais isolados, em sua maioria para subsistência.

O conhecimento geológico a respeito da Serra do Espinhaço Meridional, principalmente com respeito a Formação Sopa Brumadinho devido ao seu caráter mineralizado, possui amplo acervo de dados. O termo "Sopa”, nome atribuído aos metaconglomerados da Formação Sopa Brumadinho, apresenta controvérsias quanto a sua origem e Chaves \& Filho (2002) abordam detalhadamente a etimologia do termo. Uma provável origem consiste no fato de que após o desmonte hidráulico a rocha acumulada, devido à sua porosidade, libera gases assimilando-se à uma sopa. Outra hipótese coerente consiste no fato da matriz dos metaconglomerados ser localmente micácea, tornando-se escorregadia e consequentemente nomeadas de soapstone por 
geólogos estrangeiros ou simplificadamente "soap", tal termo foi então assimilado pelos habitantes locais como “sopa”. Outra hipótese consiste na distribuição dos clastos do metaconglomerado, que dispostos de maneira caótica, em corte assemelham-se à uma sopa.

Chaves \& Filho (2002) abordam ainda o histórico de descobertas do minério na região. A primeira referência sobre a descoberta de diamantes no Brasil é devida ao pioneiro José Bonifácio de Andrada e Silva, que publicou no final do século XVIII em Paris sua obra "Memória sobre os diamantes no Brasil”. Outro vanguardista foi o Barão Von Eschwege, que chamado ao Brasil em 1810 por Dom João VI efetuou diversos estudos, incluindo a região do Espinhaço Meridional e seus diamantes, como pode ser verificado nas obras “Quadro geognóstico do Brasil e a provável rocha matriz do diamante” em 1822 e “Pluto Brasiliensis” em 1833. 


\section{CAPÍTULO 2}

\section{REFERENCIAL TEÓRICO}

\section{1 - Contexto Geológico Regional}

O termo Espinhaço tem sido abordado com três conotações distintas: geográfico, estratigráfico e geodinâmico (Schobbenhaus, 1993). O termo geográfico foi concebido por Eschwege em 1822, para delimitar uma cadeia de montanhas de aproximadamente $1200 \mathrm{~km}$. O termo estratigráfico é referente ao Supergrupo Espinhaço, unidades depositadas na evolução de um rifte intracontinental. O conceito geodinâmico é utilizado para definir o ciclo de deposição, deformação e metamorfismo atuantes no Espinhaço. A serra amalgama-se, para nordeste, com a Faixa Araçuaí.

Deste modo, a Serra do Espinhaço pode ser segmentada em 4 grandes domínios geotectônicos (Figura 2.1): Serra do Espinhaço Meridional, que possui início no quadrilátero ferrífero e se estende até a região de Olhos D’Água; Serra do Cabral, localizada à oeste e sobre o Cráton São Francisco; Serra do Espinhaço Setentrional, com início no estado de Minas Gerais e se prolongando até o Estado da Bahia, com deslocamento para NNE; Chapada Diamantina, localizada no interior do estado da Bahia.

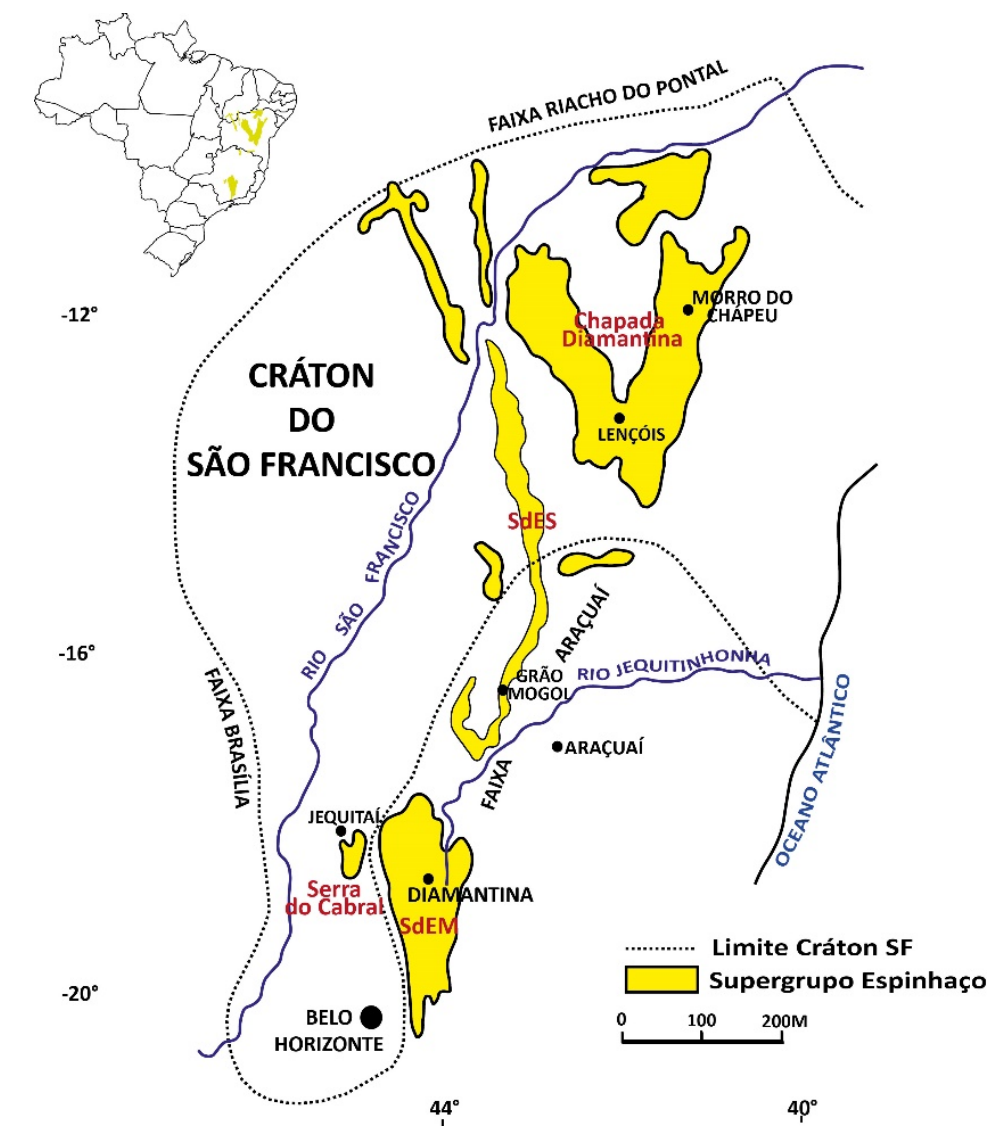

Figura 2.1 - Limites aproximados do Cráton do São Francisco destacando a Serra do Espinhaço. SdEM: Serra do Espinhaço Meridional, SdES: Serra do Espinhaço Setentrional (modificado de Chaves, 1997). 
A Serra do Espinhaço Meridional compreende uma faixa orogênica proveniente de processos de rifteamento com sedimentação predominantemente quartzítica, este segmento delimita a bora sudeste do Cráton do São Francisco.

O presente trabalho possui como escopo a tipificação dos filitos hematíticos, rochas exóticas aflorantes na Serra do Espinhaço Meridional. Tal segmento estende-se por cerca de 300 km, sustentado principalmente por rochas do Supergrupo Espinhaço.

A porção meridional da Serra do Espinhaço possui embasamento constituído por uma sucessão de rochas ígneas de idade arqueana recobertas por unidades metassedimentares e subordinadamente metavulcânicas proterozoicas. Esta sucessão sedimentar teve origem a partir de uma série de eventos extensionais, de modo que todo o pacote foi deformado e metamorfisado durante evento orogenético Neoproterozoico.

Existem controvérsias quanto ao evento deformacional atuante na Serra do Espinhaço, de modo que um suposto evento orogenético teria ocorrido entre 1,3 e 1,0 Ga, denominado evento orogenético Espinhaço ou Uruaçuano (Almeida Abreu, 1993,1995; Almeida Abreu \& Renger, 2002; Schobbenhaus \& Brito Neves, 2003). Contudo, a existência de um evento posterior ao Transamazônico e anterior ao Brasiliano é contestado por diversos autores (Uhlein, 1991; Uhlein et al., 1995; Danderfer Filho, 2000). Neste trabalho adota-se o evento deformacional neoproterozoico Brasiliano como único atuante na Serra do Espinhaço.

Pflug (1968) dividiu a Bacia Espinhaço em oito formações da base ao topo: São João da Chapada, Sopa Brumadinho, Galho do Miguel, Santa Rita, Córrego dos Borges, Córrego da Bandeira, Córrego Pereira e Rio Pardo Grande. Tal divisão serviu de base para inúmeros trabalhos posteriores. Almeida Abreu \& Pflug (1992) incorporaram à base do Supergrupo Espinhaço a Formação Bandeirinha de Fogaça et al. (1984).

Pflug (1965, 1967, 1968) reconheceu a existência de duas séries na região de Diamantina, denominando de séries Pré-Minas e Minas, correlacionando a última com a Série Minas do Quadrilátero Ferrífero. Além disto, Pflug \& Renger (1973) reconheceram a existência de três grandes supergrupos, separados por discordâncias de importância regional, denominando-as de Supergrupos Pré-Minas, Minas (Espinhaço) e Pós-Minas (São Francisco). Da mesma forma, Schöll \& Fogaça (1979) também identificaram três grandes unidades, denominando-as de Embasamento ígneo/migmatítico, Supergrupo Rio Paraúna e Supergrupo Espinhaço. 
Após estudos abordando sedimentação, paleogeografia e estratigrafia, Martins Neto (1995b) dividiu o Supergrupo Espinhaço em seis tectonossequências: Olaria, Natureza, São João da Chapada, Galho do Miguel e Conselheiro Mata.

A Serra do Espinhaço Meridional será abordada neste trabalho como composta pelas unidades: Complexo Basal, Supergrupo Rio Paraúna e Supergrupo Espinhaço. A Figura 2.2 apresenta o mapa geológico da área de estudo com apresentação sintética das unidades serão mais bem descritas ao longo deste capítulo.

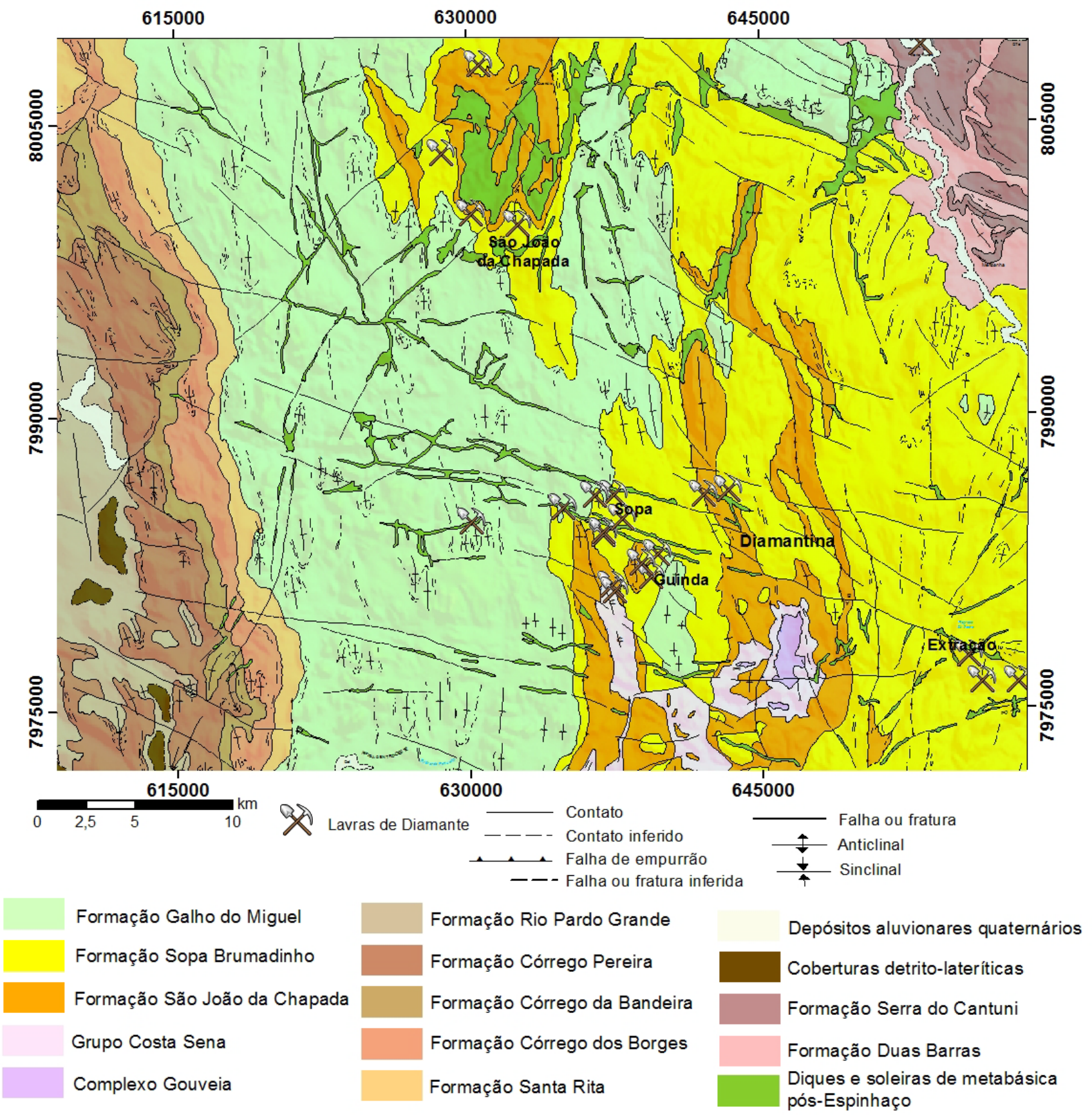

Figura 2.2 - Mapa geológico da área, de acordo com Projeto Espinhaço realizado por CODEMIG/CPRM/ Governo de Minas. 


\subsection{2 - Complexo Basal}

Unidade denominada Supergrupo Pré-Rio das Velhas por Schöll \& Fogaça (1979), é composta por granitos, gnaisses e migmatitos. Dentro da Serra do Espinhaço Meridional é composta principalmente por granitos, a exemplo do Granito Gouveia que, segundo Machado et al. (1989), apresenta idades de cristalização de 2.839 14 Ma a partir do método U/Pb. Nas porções leste e sul da Serra do Espinhaço Meridional o Complexo Basal é representado predominantemente por diferentes tipos de gnaisses, e subordinadamente por granitos, charnoquitos e granulitos (Almeida Abreu, 1995).

\subsection{3 - Supergrupo Rio Paraúna}

O Supergrupo Rio Paraúna representa uma sucessão de rochas supracrustais que aflora predominantemente na faixa mediana-central da Serra do Espinhaço Meridonal e localmente na borda sudeste desta área. A unidade inferior corresponde ao Grupo Pedro Pereira, representado por uma associação de rochas metamórficas de origem ígnea (máficas, ultramáficas e ácidas) e metassedimentos de origem química (formações ferríferas bandadas e metacherts), exibindo, invariavelmente, contatos tectônicos com rochas do Complexo Basal (Almeida Abreu, 1995).

O Grupo Costa Sena é composto pela Formação Barão de Guaicuí, representada por diversos tipos de xistos, por vezes com cianita, lazulita, dumortierita, além de clorita xistos, quartzitos, BIFs, metaconglomerados e metavulcânicas ácidas (Knauer, 2007). Possuem idades de metavulcanitos de 2,05 Ga com dados de U/Pb em zircões (Machado et al., 1989).

A unidade superior corresponde ao Grupo Costa Sena, sendo a principal unidade em expressão de ocorrência areal. Esta unidade consiste de uma sequência de sericita-xistos com quantidades variáveis de quartzo, frequentemente com cianita e eventualmente lazulita, turmalina e hematita (Almeida Abreu, 1995).

\subsection{4 - Supergrupo Espinhaço}

O Supergrupo Espinhaço constitui a unidade de maior distribuição areal na Serra do Espinhaço Meridional. O supergrupo é dividido em duas unidades principais, Grupo Guinda e Grupo Conselheiro Mata. A Figura 2.3 exibe a coluna estratigráfica do Supergrupo Espinhaço adaptada de Schöll \& Fogaça (1979). 


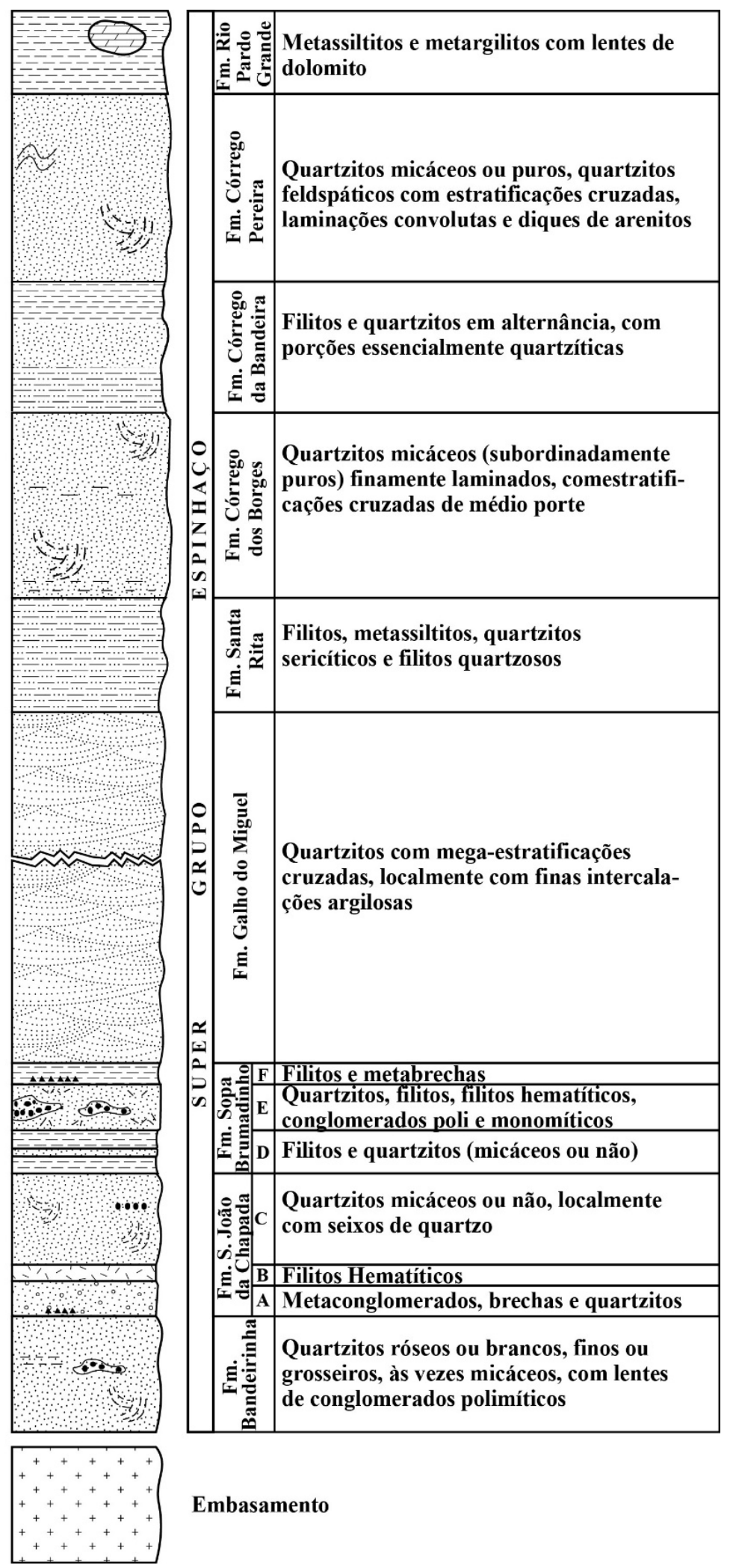

Figura 2.3- Coluna Estratigráfica do Supergrupo Espinhaço, adaptada de Schöll \& Fogaça (1979).

\subsubsection{1- Grupo Guinda}

O Grupo Guinda foi introduzido por Knauer (1990), substituindo o Grupo Diamantina anteriormente proposto por Dossin et al. (1985). Reúne as formações Bandeirinha, São João da Chapada, Sopa Brumadinho e Galho do Miguel. 


\subsubsection{1 - Formação Bandeirinha}

A Formação Bandeirinha é constituída por quartzitos, em sua maioria micáceos com estratificações cruzadas de médio porte, além de metaconglomerados e subordinadamente xistos (Knauer, 2007). Esta sucessão foi inicialmente reconhecida como unidade pré-Espinhaço, porém autores tais como Almeida Abreu (1993), Martins Neto (1993) e Silva (1995) defendem que a formação seja incorporada à base do Grupo Guinda. Advogam como principais motivos para inserção desta unidade no contexto superior da estratigrafia o fato de que: o contato da Formação Bandeirinha com os xistos da Formação Barão de Guaicuí ser tectônico; os xistos consistem, em parte, como resultantes da milonitização de rochas plutônicas (milonitos), não sendo lógico, portanto, a gradação para rochas quartzíticas. A Formação Bandeirinha possui red beds, o que é relacionado ao fim do paleoproterozoico e início do mesoproterozoico.

O presente trabalho aborda a Formação Bandeirinha como base do Supergrupo Espinhaço, contudo é de grande importância salientar todas as discussões relacionadas com a geologia da Serra do Espinhaço Meridional.

Martins Neto (1998) reconhece o Supergrupo Espinhaço como Megassequência Espinhaço e considera a Formação Bandeirinha como representada pelas tectonossequências Olaria e Natureza. Segundo o autor, os arenitos da tectonossequência Olaria formaram-se em ambiente continental, hipótese suportada pela falta de evidências de deposição sedimentar em ambiente marinho, tais como: truncamento por ondas, imaturidade textural das fácies de alta energia e predominância de arenitos exibindo intensa oxidação sin-sedimentar. A ausência de falhamentos e vulcanismo sin-sedimentares sugerem que a tectonossequência Olaria depositou-se em uma depressão inicial, tratando-se, provavelmente, do primeiro registro do processo de rifteamento ainda em condições dúcteis, sem nucleação das falhas e individualização dos meio-grábens.

A tectonossequência Natureza, embora sem vulcanismo associado, já exibe evidências de tectonismo extensional controlado por um regime de subsidência mecânica, manifestado a partir do desenvolvimento de sistemas aluviais controlados por falhas normais (Martins Neto, 1998).

\subsubsection{2 - Formação São João da Chapada}

Schöll \& Fogaça (1979) propuseram três níveis com características de ambientes continentais para a Formação São João da Chapada. O Nível A com predomínio de termos quartzíticos, o nível B representado pelos filitos hematíticos e rochas associadas e o nível C 
caracterizado pelo predomínio de quartzitos médios até grossos sobre menores quantidades de filitos que gradam lateralmente para quartzitos micáceos finos.

Segundo Almeida Abreu (1995), os depósitos rudíticos são irrisórios em termos de volume e extensão, concentrando-se quase que exclusivamente na base, constituem pacotes pouco espessos e notavelmente descontínuos. Os depósitos maiores de ruditos ocorrem quando a formação encontra-se diretamente sobre a Formação Bandeirinha, representando fanconglomerados da erosão da unidade subjacente durante deposição da unidade superior.

Tanto na Formação Bandeirinha quanto na Formação São João da Chapada a presença de lutitos é insignificante, com predominância de metarenitos puros. As seções preservadas de ambas as formações representam então segmentos proximais e intermediários de sistemas fluviais (Almeida Abreu 1993, Martins Neto 1993). Os segmentos distais, onde teoricamente estariam concentrados os depósitos de lutitos foram depositados na porção axial do rifte, zona que sofreu grande deformação com a tectônica compressional.

\subsubsection{3 - Formação Sopa Brumadinho}

A Formação Sopa Brumadinho apresenta ampla distribuição e devido ao seu potencial diamantífero dispõe de amplo acervo de dados. Almeida Abreu (1993) reconheceu três membros, denominando-os de Membro Datas, Caldeirões e Campo Sampaio.

A porção basal corresponde ao Membro Datas que é constituído por filitos e quartzo-filitos, com exposições na área de Sopa-Guinda ocorre principalmente nas escavações sobre os metaconglomerados diamantíferos do Membro Caldeirões. Geralmente são filitos esverdeados a acinzentados, ricos em sericita e mais ou menos quartzo com intercalações de metarenitos micáceos ou puros.

O Membro Caldeirões apresenta predomínio de quartzitos em relação aos conglomerados, filitos hematíticos ocorrem como corpos concordantes ou discordantes, da mesma forma que corpos de xisto verde. O nome Caldeirões é derivado da lavra de diamantes homônima localizada nas adjacências do Povoado Sopa.

O Membro Campo Sampaio, possui predomínio de metapelitos esverdeados a acinzentados. Litologia característica deste membro consiste nas metabrechas quartzíticas, compostas por fragmentos angulosos a subangulosos de quartzito imersos em matriz pelítica.

Martins Neto (1998) reconheceu intervalos tectono-deposicionais na Formação Sopa Brumadinho, que se iniciam com pelitos de provável origem lacustre e progradam para camadas 
turbidíticas. A posterior deposição de arenitos representa abandono do lobo deposicional. Aspectos como origem, características e a distribuição espacial das fácies, intercalações de depósitos trativos com fluxos gravitacionais de sedimentos, predominância de conglomerados de fluxos gravitacionais, padrão de paleo-correntes e o reconhecimento de ambientes deposicionais subaéreos e subaquáticos associados indicam tratar-se de sistema deposicional fan-deltaico. O processo de rifteamento compartimentou a bacia em blocos falhados (grábens e horsts), e a subsidência os colocou abaixo do nível de base deposicional com a formação de lagos como resposta ao tectonismo. Desta forma, o relevo diferencial forneceu os sedimentos que seriam depositados nas áreas bacinais por meio de fan-deltas.

Ainda segundo Martins Neto (1998), pulsos tectônicos proporcionaram subidas do nível de base dos lagos e o rejuvenescimento da área fonte, sugerindo a subsidência episódica que determinou a arquitetura de preenchimento da bacia. A profundidade dos lagos definiu a forma da sedimentação: em lagos profundos se desenvolveram correntes de turbidez, em lagos rasos, os sistemas entrelaçados apresentam maior expressão.

\subsubsection{4 - Formação Galho do Miguel}

A Formação Galho do Miguel destaca-se com relevo positivo, irregular e fortemente acidentado, feição que é evidenciada ao longo de seus limites orientais na faixa mediana-central da Serra do Espinhaço Meridional, onde o proeminente degrau topográfico pode ser acompanhado, na direção N-S, por mais de uma centena de quilômetros (Almeida Abreu, 1989). A formação é composta quase que exclusivamente por quartzitos de granulometria fina a média com menor frequência de metarenitos micáceos e níveis pelíticos. Possui estratificações cruzadas de grande porte como estruturas características e localmente bimodalidade granulométrica.

Os quartzitos atingem espessuras da ordem de 500 m nas proximidades de Gouveia até prováveis 2.000 m em direção ao norte (Schöll \& Fogaça, 1979). As características deposicionais relacionadas à formação indicam sedimentação em sistema eólico (Dossin et al., 1987).

\subsubsection{2 - Grupo Conselheiro Mata}

As cinco formações deste grupo apresentam contatos concordantes, o que pode representar ambientes sedimentares contíguos com contribuições fluviais discretas (Koster, 1984). O grupo é composto pelas formações Santa Rita, Córrego dos Borges, Córrego da Bandeira, Córrego Pereira 
e Rio Pardo Grande. Possui ocorrência restrita à porção ocidental da serra, é constituído por alternâncias cíclicas de sedimentos arenosos finos com siltitos e argilitos em ambiente marinho.

A Tabela 2.1 exibe as principais características das unidades que compõem o Supergrupo Espinhaço.

Tabela 2.1 - Estratigrafia do Supergrupo Espinhaço de acordo com Pflug (1968), Scholl \& Fogaça (1979) e Almeida Abreu \& Pflug (1994), adaptado de Almeida Abreu (1996).

\begin{tabular}{|c|c|c|c|c|c|}
\hline & Grupo & & Formação & Litologia & Ambiente de sedimentação \\
\hline \multirow{11}{*}{ 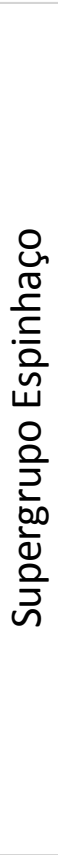 } & \multirow{5}{*}{ 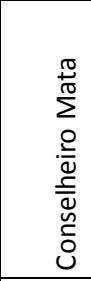 } & \multicolumn{2}{|c|}{ Rio Pardo Grande } & $\begin{array}{l}\text { Metapelitos, subordinadamente metarenitos, } \\
\text { localmente dolomitos }\end{array}$ & \multirow{5}{*}{$\begin{array}{l}\text { Marinho raso de baixa energia, } \\
\text { mostrando oscilações do nível do } \\
\text { mar com incursões episódicas de } \\
\text { sedimantação fluvial e eólica na } \\
\text { plataforma marinha }\end{array}$} \\
\hline & & \multicolumn{2}{|c|}{\begin{tabular}{|l} 
Córrego Pereira \\
\end{tabular}} & Metarenitos puros a micáceos, localmente pelitos & \\
\hline & & \multicolumn{2}{|c|}{ Córrego da Bandeira } & Metarenitos e metapelitos & \\
\hline & & \multicolumn{2}{|c|}{ Córrego dos Borges } & $\begin{array}{l}\text { Metarenitos puros ou micáceos, localmente } \\
\text { brechas/conglomerados quartzíticos }\end{array}$ & \\
\hline & & \multicolumn{2}{|c|}{ Santa Rita } & Metapelitos, subordinadamente metarenitos & \\
\hline & \multirow{6}{*}{$\underset{\substack{\frac{\pi}{O} \\
\frac{C}{J}}}{0}$} & \multicolumn{2}{|c|}{ Galho do Miguel } & Metarenitos puros & Eólico "rifte progradante" \\
\hline & & \multirow{3}{*}{ 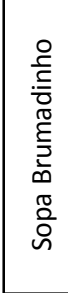 } & Membro Campo Sampaio & $\begin{array}{l}\text { Metapelitos, subordinadamente metarenitos e } \\
\text { metabrechas quartzíticas de matriz pelítica }\end{array}$ & Lacustre com incursões fluviais \\
\hline & & & Membro Caldeirões & $\begin{array}{l}\text { Metarenitos, metaconglomerados polimíticos, filitos } \\
\text { hematíticos }\end{array}$ & $\begin{array}{l}\text { Fluvial e leques aluviais } \\
\text { progradantes }\end{array}$ \\
\hline & & & Membro Datas & Metapelitos e subordinadamente metarenitos & $\begin{array}{l}\text { Lacustre, localmente playa na } \\
\text { base }\end{array}$ \\
\hline & & \multicolumn{2}{|c|}{ São João da Chapada } & $\begin{array}{l}\text { Metarenitos, localmente metaconglomerados e } \\
\text { filitos hematíticos }\end{array}$ & $\begin{array}{l}\text { Fluvial braided. Filitos } \\
\text { hematíticos: paleosolos de rochas } \\
\text { ígneas }\end{array}$ \\
\hline & & \multicolumn{2}{|c|}{ Bandeirinha } & $\begin{array}{l}\text { Metarenitos puros ou micáceos (muitas vezes red } \\
\text { beds), localmente metaconglomerados e } \\
\text { metapelitos }\end{array}$ & $\begin{array}{l}\text { Fluvial, localmente com leques } \\
\text { aluviais e depósitos eólicos }\end{array}$ \\
\hline
\end{tabular}

\section{2 - Evolução da Bacia}

Para melhor compreensão da natureza dos filitos hematíticos se faz necessário analisar o processo evolutivo da Bacia Espinhaço. A gênese dos filitos está diretamente relacionada com processos distensionais atuantes durante a fase de rifteamento, de modo que é consenso entre estudiosos que descompressão adiabática do manto possibilitou ascensão de magmas básicos à ultrabásicos até a superfície.

Segundo Silva (2013) a base da bacia Espinhaço, como esperado de um rifte, é marcada por magmatismo de natureza bimodal, com a erupção de magmas félsicos e básicos. As rochas metavulcânicas de caráter básico são representadas pelos filitos hematítico, enquanto as rochas ácidas são representadas por metarriolitos localizados na borda leste da cordilheira. As rochas foram datadas em 1,7 Ga (Brito Neves et al. 1979, Machado et al. 1989), conferindo à tal período uma importância especial no magmatismo e atividades tectônicas extensionais. 
Através do sistema de falhas normais vigente ocorreu a rotação dos blocos, que por sua vez possibilitou a erosão da área fonte elevada e deposição no depocentro da bacia. Este cenário é comum em regiões com riftes assimétricos, constituídos por rampas inclinadas, que mergulham em direção à falha normal principal.

O processo evolutivo da bacia pode ser dividido nas fases rifte, transicional, flexural e inversão tectônica.

\subsection{1 - Fase Rifte}

As três unidades inferiores do Supergrupo Espinhaço, isto é, as formações Bandeirinha, São João da Chapada e Sopa Brumadinho, constituem uma série de sedimentos terrígenos característicos de ambientes fluviais entrelaçados, deltáico e marinho pouco profundo (Garcia \& Uhlein 1987), depositada na fase principal do rifte. As rochas mais abundantes são quartzitos intercalados com metassedimentos impuros, filitos e metaconglomerados diamantíferos. Durante o processo extensional o afinamento crustal resultou na ascensão astenosférica e consequente fusão do manto por descompressão adiabática, desta forma permitindo a ascensão à superfície de magmas de natureza alcalina, o que pode sugerir intrusões de rochas precursoras dos filitos hematíticos.

Após a fase principal do rifte instala-se ambiente eólico a marinho raso, correspondente à Formação Galho do Miguel, marcada pela deposição de espessas camadas de quartzito e registrando a porção superior da sequência rifte.

A espessura preservada do pacote corresponde à cerca de $850 \mathrm{~m}$, o que constitui um valor restrito em relação à espessuras de outros riftes com evolução semelhante. O processo erosivo foi notável na formação das descontinuidades, o que pode explicar a espessura da bacia. O paleodeclive é normal ao eixo do rifte, o que leva a acreditar que a falha principal (master fault) encontra-se à leste da área de estudo, uma vez que os sistemas de transporte lateral progradantes são alimentados a partir da borda flexural do rifte (Martins Neto, 1998).

\section{Fase Rifte-1}

O início do Rifte Espinhaço apresenta idades que variam entre 1752 e 1748 Ma segundo Machado et al. (1989) e Schobbenhaus et al. (1994). Tal idade coincide com a ocorrência de diversos processos extensionais ocorridos em escala global.

A ausência de falhamentos e vulcanismo sin-sedimentares sugerem que Formação Bandeirinha depositou-se em uma depressão inicial, provavelmente resultado de estiramento dúctil, antes de atingir o limite elástico da crosta (Martins Neto 1998). Dessa forma, foi o primeiro 
registro do processo de rifteamento (fase pré-rifte), anterior à nucleação das falhas de meiográbens.

O registro sedimentar/vulcânico encontra-se preservado na porção mediana-central e nordeste da Serra do Espinhaço Meridional. Na porção central é representado pelos sedimentos da Formação Bandeirinha, depositados em ambiente fluvial com contribuição eólico e aluvial. A ocorrência de red beds em tal formação é coerente com a idade de sedimentos semelhantes que ocorrem em outras localidades, todos datando em torno de 1750 Ma. O contato da Formação Bandeirinha com os xistos do Grupo Costa Sena consiste em um detachment fault, o que é explicado pelo fato da descontinuidade interceptar ambas as unidades e pelo nítido contraste metamórfico e deformacional (Almeida Abreu, 1995).

A extensão crustal foi acomodada por uma master fault vergente para oeste, sendo que os blocos da Formação Bandeirinha foram basculados para leste. Desta forma, os falhamentos que acomodaram a deformação extensional provocaram a exumação das rochas subjacentes, levando até a superfície rochas da crosta intermediária e formando um corel complex composto pelos xistos do Grupo Costa Sena e do Complexo Basal (Almeida Abreu, 1995).

\section{Fase Rifte-2}

De acordo com Almeida Abreu (1995), a fase subsequente é marcada por refletir, ao contrário da primeira, um relaxamento termal da crosta com instalação de uma ampla bacia fluvial onde foi depositada a Formação São João da Chapada. Sendo assim, em tal período de formação da bacia praticamente inexistiu atividade tectônica. A sedimentação possui fluxo progradante de W para E, como exemplo das demais unidades do Supergrupo Espinhaço nesta porção da serra. Alternadamente ocorrem depósitos agradacionais, sugerindo, portanto, que períodos de sedimentação e a evolução dessa bacia foram controlados por subsidência mecânica sob regime climático permanentemente úmido.

Arenitos médios, localmente sigmoidais, organizados em sucessões de coarsening/thickening upward de provável origem deltáica progradam sobre a sucessão transgressiva lacustre, indicando formação de uma planície entrelaçada efêmera. A progradação do sistema entrelaçado indica suprimento de sedimentos superior à taxa de subsidência.

\section{Fase Rifte- 3}

A terceira e última fase de desenvolvimento do rifte é marcada pela deposição da Formação Sopa Brumadinho, período que reflete o pico da atividade tectônica atuante no Espinhaço Meridional. Marcada pela retomada do processo extensional novamente associada à anomalia 
térmica do manto. O ápice deste aquecimento possivelmente foi causado por processos de delaminação da litosfera que permitiu a subida da astenosfera à base da crosta. De acordo com Almeida Abreu (1995) tal fato explica o extensivo vulcanismo kimberlítico, evidenciado pela notável ocorrência diamantífera nos metaconglomerados da Formação Sopa Brumadinho.

A atividade tectônica em nível crustal foi intensa, como pode ser verificado pelas espessas e amplamente distribuídas fácies de ruditos da Formação Sopa Brumadinho e suas complexas relações com as fácies lacustres, pelíticas e areníticas.

Segundo Almeida Abreu (1995), o foco da deformação progradou sucessivamente para leste em consequência da rotação dos blocos em detrimento da movimentação crustal e assim diminuição do ângulo das falhas normais, uma vez que a crosta durante o processo extensional afasta-se progressivamente do foco termal. A crosta que permaneceu sendo segmentada pela incidência de sucessivos falhamentos normais fica sujeita à intrusão de diápiros mantélicos, decorrentes da ascensão astenosférica. Ao longo da borda leste da serra há intrusões de rochas serpentinizadas imbricadas tectonicamente com metassedimentos do rifte e de suas unidades marinhas.

Falhas de transferência de sentido E-W desempenharam papel importante na compartimentação do rifte. O caráter sinistral é sugerido pela distribuição regional da Formação Sopa Brumadinho, evidenciado e corroborado pelas localizações das províncias diamantíferas que de norte a sul deslocam-se para leste (Martins Neto, 1995).

Dados recentes de Chemale Jr et al. (2011) obtidos por métodos U-PB em zircões detríticos da matriz de metaconglomerados da Formação Sopa Brumadinho fornecem idades de 1.19 Ga, indicando uma diferença de aproximadamente 500 Ma entre a deposição do denominado Espinhaço Inferior (formações Bandeirinha e São João da Chapada) e Espinhaço Superior (formações Sopa Brumadinho e Galho do Miguel).

\subsection{2 - Fase Transicional}

Segundo Martins Neto (1998) a fase transicional evidencia o surgimento do caráter marinho durante o processo de sedimentação, em contraste com a fase rifte que evoluiu a partir de meio-grábens de direção aproximada N-S e sedimentação continental preferencialmente aluvial.

Esta fase é marcada pela deposição da Formação Galho do Miguel. Ocorre então uma mudança do regime de subsidência da bacia de mecânico compensado localmente para termal compensado regionalmente, acompanhando menores taxas de subsidência. Dessa forma, mantém- 
se o suprimento sedimentar e é reduzido o espaço de acumulação, ocorrendo uma expansão na área da bacia sobre todo o território do rifte e avançando sobre o embasamento.

A fase transicional é marcada inicialmente por pequeno suprimento sedimentar em relação à subsidência/subida do nível do mar, permitindo o desenvolvimento de uma sucessão transgressiva. Em seguida um aumento da taxa de sedimentação provocou a formação de uma sucessão progradacional coarsening-upward. Uma sucessão de filitos marca a batimetria máxima no mar da região e a transição da sucessão transgressiva para progradacional. Depósitos de shoreface e zona de transição caracterizam a sucessão transgressiva, enquanto uma sequência de offshore, zona de transição, lower shoreface, upper shoreface e praia caracterizam a sucessão progradacional. A sedimentação em ambas as sucessões foi marcada por ação de ondas. $\mathrm{O}$ avanço da linha de costa para leste foi controlado pelo excesso de suprimento relativamente ao espaço de acomodação, levando ao desenvolvimento de extensos campos de dunas que caracterizam a Formação Galho do Miguel. Durante a evolução da bacia em tal momento houve sedimentação eólica e marinha, com predominância de eólica e ocorrência de sistema marinho na porção axial da bacia (Martins Neto, 1998).

\subsection{3 - Fase Flexural}

A fase flexural é representada pela sedimentação do Grupo Conselheiro Mata. Uma sucessão rítmica transgressiva marca a passagem entre as unidades Galho do Miguel e Conselheiro Mata, podendo ser observada na borda leste da Serra do Cabral. O Grupo Conselheiro Mata é constituído pelas formações Santa Rita, Córrego dos Borges, Córrego da Bandeira, Córrego Pereira e Rio Pardo Grande.

Essa sequência não apresenta conglomerados na base e seu desenvolvimento está relacionado a movimentos de subsidência flexural, que induziu uma transgressão e a consequente deposição de sedimentos marinhos rasos diretamente acima de sedimentos continentais (Silva, 1998).

Almeida Abreu (1995) destaca que as litologias reunidas no Grupo Conselheiro Mata representam apenas parte do prisma sedimentar da plataforma continental da margem passiva Espinhaço. Sedimentos pertencentes à unidade podem ter sido erodidos antes e durante a sedimentação do Grupo Macaúbas, provavelmente incluindo uma plataforma carbonática, uma vez que os metatilitos presentes na Formação Jequitaí possuem carbonato abundante na forma de clastos ou matriz, esse material seria proveniente da área montanhosa definida pelo sistema Espinhaço. 


\subsection{4 - Fase de Inversão}

Após todas as fases relacionadas com a instalação do rifte Espinhaço e evolução da bacia sedimentar, ocorre então inversão tectônica a partir de mudanças nos vetores de tensões de deformação crustal, de modo que durante o Neoproterozoico a sequência Espinhaço foi empurrada para oeste em direção ao Cráton do São Francisco, formando o cinturão de dobras brasiliano com vergência para oeste e que bordeja a porção ocidental do orógeno Araçuaí.

Contudo, Almeida Abreu (1995) defende a ocorrência de evento metamórfico durante o Mesoproterozoico, destacando que entre o Grupo Macaúbas e o Supergrupo Espinhaço ocorre nítida discordância angular, indicando que após a inversão tectônica as rochas do Supergrupo Espinhaço foram fortemente erodidas, com remoção de mais de 5000 metros de metassedimentos atingindo localmente suas raízes. Outro ponto abordado pelo autor é a ocorrência de rochas básicas (diabásios e metagrabos) pós-orogenéticas, que em datações U/Pb foram obtidas idades de 906 2 Ma.

Em resumo, a formação da Serra do Espinhaço pode ser representada pela seguinte sucessão de eventos:

- Individualização de núcleo continental durante o Arqueano, representado pelo Complexo Basal;

- Rifteamento proterozoico e formação da Bacia Espinhaço, falhamentos normais orientados N-S controlaram a sedimentação e possibilitaram a ascensão de magmas por descompressão do manto, propiciando vulcanismo ácido à ultrabásico, com destaque ao magmatismo que deu origem aos filitos hematíticos;

- Sedimentação com aporte das regiões elevadas em sistema de rios entrelaçados e leques aluviais, constantemente reativados pela tectônica vigente;

- Variação do regime de subsidência da bacia, com predomínio da sedimentação eólica em relação a sedimentação marinha na Formação Galho do Miguel;

- Assoreamento da bacia com mudança para ambiente estável e transgressão do Grupo Conselheiro Mata;

- Inversão da bacia durante o Brasiliano, com transporte de massa em direção ao Cráton (oeste), assim como metamorfismo regional em fácies xisto verde;

- Processos erosivos recentes são responsáveis pela modelagem do relevo e consequentemente na dispersão dos diamantes em ambiente sedimentar. 


\section{3-Geologia do Diamante}

Os mecanismos de ascensão de diamantes desde o manto à superfície correspondem a assunto intensamente abordado na literatura, contudo indagações permanecem ativas. Atualmente é universal o fato de que a ascensão ocorre, preferencialmente, por meio de rochas ultrabásicas de caráter explosivo, uma vez que alcançam a superfície em questão de horas.

Em uma breve síntese abordando a descoberta de diamantes a partir de fonte primária, Draper (1905) relata que o primeiro garimpo em rocha kimberlítica se iniciou em 1869, quando na sua presença Cornelius Duplooy exibiu diamantes encontrados no local em que retirava barro para construção de sua casa. Com a descoberta de tais rochas, denominadas garimpos secos em contraste com os garimpos aluvionares, e posterior descoberta de um garimpo seco com diamantes de maior porte na fazenda dos irmãos De Beers levou a grande corrida para esta área, denominada De Beers Rush. O surgimento de outro garimpo seco 3,5 km a oeste causou outra corrida, denominada De Beers New Rush, de modo que a cidade de Kimberley cresceu entre os dois garimpos (Janse, 1984).

Apesar da descoberta de diamantes em 1869, a associação com condutos vulcânicos ocorreu somente em 1872, quando Ernst Cohen escreveu sobre pipes de tufos eruptivos portadores de diamantes (Janse, 1984). Em 1887 Henry Carvill Lewis introduziu o termo kimberlito para tais rochas devido à ocorrência da mesma nas proximidades da cidade de Kimberley, África do Sul (Clement et al., 1984).

Contudo, os primeiros diamantes encontrados em rocha compacta foram em 1839, próximo a cidade de Diamantina, Minas Gerais, em rocha metamórfica de origem sedimentar. Tal fato despertou a atenção e outros depósitos semelhantes foram encontrados em demais localidades do mundo (Pereira, 2007).

Em 1978 foi descoberto em Ellendale, região norte da Austrália, uma rocha diamantífera com características distintas das convencionais, o que gerou certo impacto. Porém em 1979 foi descoberta a intrusão Argyle, com teores de diamante significativos e a rocha foi classificada como olivina lamproíto. Ambas as intrusões estão localizadas em cinturões dobrados Proterozoicos marginais à blocos cratônicos, o que até o momento não seria possível, pois o manto litosférico de tais terrenos não forneceria as condições ideais para preservar o diamante. Dentre as propriedades que diferem lamproítos de kimberlitos destacam-se o ambiente tectônico de ocorrência, mineralogia, formato do corpo intrusivo, presença de $\mathrm{CO}_{2}$ e ausência da extensa zona de diatrema característica dos kimberlitos (Pereira, 2007). 
Ainda segundo Pereira (2007), no Brasil entre o final da década de sessenta e os anos 2000 descobriram-se centenas de intrusões kimberlíticas e rochas relacionadas. Entre cerca de duas mil intrusões aproximadamente duas dezenas possuem diamantes em teores baixos e apenas um kimberlito foi avaliado como economicamente viável.

Assim como a descoberta dos lamproítos australianos revolucionou a prospecção de diamantes em escala mundial, novas rochas potencialmente econômicas podem ser reveladas. Desta maneira, uma atenção especial deve ser dada às rochas não-kimberlíticas, pois as mesmas podem apresenta-se como importantes fontes de diamantes.

Para determinar a natureza da rocha fonte dos diamantes da Serra do Espinhaço Meridional é necessário realizar uma retrospectiva das principais fontes primárias conhecidas. Desta forma, torna-se necessário efetuar uma retrospectiva com dados da literatura abordando as principais características das fontes clássicas de diamantes, com o propósito de verificar em qual classificação melhor se adequa o filito hematítico. As rochas fontes possuem particularidades, tais como modo de ocorrência, aspectos mineralógicos e condições de magmatismo que auxiliam na determinação do possível protolito do filito hematítico.

Sem dúvidas, a ocorrência mais recorrente e difundida trata-se do kimberlito, seguindo o modelo clássico Sul Africano. Contudo, demais fontes evidenciam enorme potencial, particularmente lamproítos e lamprófiros.

\subsection{1- Kimberlito}

Após a disseminação do conceito de kimberlito, toda rocha portadora de diamante foi sistematicamente classificada como tal, não levando em consideração a assembleia mineral presente. Wagner (1928) reconheceu a diferença existente entre os dois principais tipos de kimberlitos, basálticos e micáceos/lamprófiros, classificando os kimberlitos micáceos como um novo tipo de rocha, denominados orangeitos.

Nos anos 70 do século passado estudos petrográficos mais modernos foram realizados a fim de revisar a classificação de Wagner, porém até hoje termos de Wagner são utilizados, de modo que kimberlitos ricos em mica são referenciados como kimberlitos micáceos com implicação aos kimberlitos sul africanos descritos por Wagner (1914). Mitchell (1970) propôs grandes mudanças na classificação dos kimberlitos, uma vez que abandonou o termo "kimberlito basáltico”, porquanto que os mesmos não possuem feldspato nem qualquer correlação genética com rochas basálticas, além de classificar os kimberlitos em três variedades de acordo com a composição modal dos minerais olivina, flogopita e calcita denominados, respectivamente, 
kimberlito, kimberlito micáceo e kimberlito calcítico. Smith (1983) observou que montcelitacalcita-serpentina kimberlitos e flogopita kimberlitos do Cráton Kaakvaak (África do Sul) possuem composições isotópicas de $\mathrm{Sr}$ e $\mathrm{Nd}$ distintas, assim sugeriu que montcelita calcita serpentina kimberlitos fossem denominados kimberlitos grupo I e flogopita kimberlitos tipo II, sendo derivados do manto astenosférico e litosférico, respectivamente.

Atualmente a redefinição feita por Clemente et al. (1984) é bem aceita, segundo os autores o "kimberlito é uma rocha ígnea, rica em voláteis, potássica, ultrabásica, que ocorrem em pequenos pipes vulcânicos, diques e sills. Apresenta textura inequigranular resultante da presença de macroscristais inseridos em matriz de granulação mais fina. A matriz contém olivina, flogopita, carbonato (comumente calcita), serpentina, clinopiroxênio (comumente diopsídio), monticelita, apatita, espinélio, perovskita e ilmenita como fenocristais primários proeminentes e/ou constituintes da mesma. Os macrocristais são minerais ferromagnesianos derivados do manto, anédricos, incluindo olivina, flogopita, picroilmenita, cromo espinélio, granada magnesiana, clinopiroxênio (comumente cromo diopsídio) e ortopiroxênio (comumente enstatita). Olivina é extremamente abundante em relação aos outros macrocristais, os quais não precisam necessariamente estar presentes. Os macrocristais e os minerais da matriz formada relativamente cedo são comumente alterados por processos deutéricos, principalmente serpentinização e carbonatação. Kimberlito geralmente contém inclusões de rochas ultramáficas derivadas do manto superior. Quantidades variáveis de xenólitos crustais e xenocristais também podem estar presentes. Kimberlito pode conter diamante, mas somente como constituinte muito raro”.

O caráter ultrabásico da rocha é claramente evidenciado na bibliografia, com teores de sílica raramente ultrapassando os $40 \%$ em peso. Os voláteis são característicos e representativos nos magmas kimberlíticos, de modo que os teores de $\mathrm{H}_{2} \mathrm{O}$ e $\mathrm{CO}_{2}$ correspondem a 5 e $10 \%$ em peso, respectivamente. São rochas tipicamente alcalinas, o que pode ser explicado pelo alto teor de $\mathrm{K}_{2} \mathrm{O}$, com o potássio hospedado principalmente na flogopita. A elevada razão $\mathrm{K}_{2} \mathrm{O} / \mathrm{Na}_{2} \mathrm{O}$ é característica de rochas kimberlíticas.

Apesar de sua importância, os kimberlitos ainda mantêm indagações a serem melhor esclarecidas, mesmo com o avanço do conhecimento, com definições mais precisas, determinados conceitos ainda são soltos e alvo de opiniões divergentes, principalmente em relação ao seu processo de formação.

\subsubsection{Lamproíto}

Scott Smith \& Skinner (1984) definem lamproíto como rocha ultrapotássica magnesiana. Caracteriza-se pela alta razão $\mathrm{K}_{2} \mathrm{O} / \mathrm{Na}_{2} \mathrm{O}$ tipicamente maior que cinco. Possuem concentrações 
altas de Cr e Ni e extremamente elevadas nos elementos Rb, Sr, Zr e Ba. Ao contrário do kimberlito, $\mathrm{CO}_{2}$ é praticamente ausente. Lamproíto contém quantidades variáveis de leucita como fenocristal primário ou como constituinte da matriz junto com vidro, seguidos de flogopita (tipicamente titanífera), clinopiroxênio (tipicamente diopsídio), anfibólio (richeterita titanínera potássica), olivina e sanidina. Priderita, perovskita, apatita, wadeita e espinélio podem estar presentes. A distinção entre lamproíto e kimberlito é feita pela presença, no primeiro, de leucita, anfibólio, sanidina, vidro, priderita, wadeita e ausência de monticelita, carbonato e serpentina primária.

Ao contrário dos kimberlitos, lamproítos apresentam profundidade de cristalização que não ultrapassa os 500 m, ao invés dos 2 km que pode atingir um kimberlito, o que resulta na ausência das extensas zonas de diatrema. Podem ocorrer variações na composição de acordo com a profundidade do corpo, como visto por Cullers \& Berendsen (2011).

Uma vez que ocorre ampla variação de composição química, a classificação e reconhecimento de rochas lamproíticas nem sempre são intuitivos, ainda mais quando se trata de rochas metamórficas em elevado estado de alteração, cujo processo descaracteriza a rocha original dificultando seu reconhecimento.

\subsection{3- Lamprófiro}

Lamprófiros são rochas singulares, talvez pela sua forma de ocorrência, aparência ou ausência de feições características. Porém, sua importância é notória como fonte de informações dos processos atuantes no manto, como indicadora de minérios, em especial ouro e diamante, assim como magma parental de uma variedade de rochas, incluindo um grande leque de minerais e composições químicas.

Segundo Rock (1991) o temo lamprófiro é derivado do grego “lampros porphyros”, com sentido de "rocha roxa" devido a ocorrência de fenocristais de biotita. Um problema recorrente na literatura consiste na definição de qualquer rocha de difícil classificação como lamprófiro, ou seja, criou-se uma incerteza e insegurança na definição exata de lamprófiros.

A IUGS Subcommission of Igneous Rocks Systematics reconheceu três grupos de lamprófiros (cálcio-alcalino, alcalino e ultramáfico). Posteriormente, foi aceito a inclusão de lamprófiros, kimberlitos e lamproítos como rochas lamprofiríticas.

Após a descoberta de diamantes nos lamproítos australianos, rochas antes denominadas kimberlitos foram reclassificadas. Com isto, não ocorreu somente a confirmação da ocorrência de 
diamante em outros lamproítos, mas também em outras duas variedades de lamprófiros (damkjernitos e monchiquitos) no oeste da Austrália (Rock 1991).

Lamprófiros são compostos essencialmente por anfibólio e/ou flogopita, podendo conter minerais com valores elevados de $\mathrm{F}, \mathrm{Cl}, \mathrm{SO}_{3}, \mathrm{CO}_{2}$ e $\mathrm{H}_{2} \mathrm{O}$. Altos teores de $\mathrm{Ba}, \mathrm{Fe}^{3}$, $\mathrm{Al}$ e/ou Ti em K-feldspatos, anfibólios, flogopitas e piroxênios são característicos. Minerais máficos ricos em Mg são comuns, com destaque para diopsídio e forsterita, ocorrendo juntamente com feldspatos ricos em $\mathrm{K}$ e Na. Lamprófiros são mesocráticos à melanocráticos, porfiríticos usualmente com textura pan-idiomórfica e ausência de fenocristais de feldspato ou quartzo (Rock, 1991).

\subsection{4 - Rochas Diamantíferas Não Usuais}

Rochas diamantíferas não usuais constituem potenciais fontes de diamantes a serem exploradas. Tais rochas são quaisquer que não sejam classificadas como kimberlíticas ou lamproíticas. Dessa forma, demais fontes de diamantes são passíveis de serem descobertas, visto que muitas áreas mineralizadas ainda encontram-se sem fonte primária definida, apesar dos esforços em identificá-las.

Por vezes a ocorrência de diamantes em rochas não usuais é desvalorizada, uma vez que maior parte dos investimentos e pesquisas é direcionada para rochas diamantíferas clássicas. Segundo Erlich \& Hause (2002) possivelmente os lamprófiros, em especial os minetes diamantíferos, serão o próximo grupo de rochas que revolucionará o significado de rochas convencionais. Segundo os autores, uma grande variedade de rochas não usuais ainda será identificada. Diamantes foram descobertos em alnoitos (Helmstaedt, 1993), mochiquitos no Oeste da Austrália (Jaques et al., 1986) e lamprófiros em Quebec (Helmstaedt, 1993).

Além disso, Dawson (1967) relatou a presença de diamantes em clorita xistos em Birrimian, Gana, tais xistos foram interpretados como resultado metamórfico de basaltos, rochas ultrabásicas e grauvacas. Barron et al. (1994) identificaram a presença de diamante em eclogitos, piroxenitos e jadeitos na China.

Com isto, percebe-se que a possibilidade do filito hematítico ser a fonte dos diamantes da Serra do Espinhaço Meridional é totalmente plausível, uma vez que há uma variedade de litologias que podem representar a rocha original. 


\section{4- Filitos Hematíticos}

Visto a variedade de litologias que podem ocorrer mineralização de diamantes, o filito pode ser representado por uma vasta diversidade de rochas. Contudo, devido às condições atípicas dos filitos hematíticos que dificultam a classificação precisa de seu protolito, torna-se arriscado tentar defini-lo como rocha não usual. Neste caso, o filito será abordado como rocha convencional kimberlítica/lamproítica na tentativa determinar em qual destas litologias o filito hematítico melhor se enquadra, discussão que será realizada no Capítulo 5.

Os filitos hematíticos são rochas exóticas que apresentam uma série de controvérsias quanto à sua origem e significado geológico. A primeira controvérsia tratou-se de sua origem, indefinida quanto ígnea ou sedimentar, contudo sua origem ígnea é aceita por diferentes autores desde Correns (1932).

Uma classificação textural do filito hematítico foi proposta por Schöll \& Fogaça (1981), sendo reconhecidas quatro variedades de ocorrências distintas: mosqueada, relicta, difusa e bandada. A textura mosqueada é assim denominada pela existência de processos irregulares de lixiviação, formando manchas esbranquiçadas. A textura relicta é marcada pela ocorrência de cristais tabulares sericitizados, lembrando a pré-existência de feldspatos e com arranjos indicando textura original subofítica/ofítica. A textura difusa é caracterizada por raramente apresentar concentrações de óxidos. Por fim, a textura bandada é marcada pela alternância em níveis mais ricos de hematita. Contudo, esta é uma diferenciação puramente textural, não ocorrendo distinção em termos estratigráficos e geográficos.

Diferentes autores defendem que este conjunto de rochas seria a fonte dos diamantes da Serra do Espinhaço Meridional, relatos de recuperação de diamantes a partir do filito hematítico suportam esta teoria, tanto na Serra do Espinhaço Meridional quanto na Chapada Diamantina, no estado da Bahia. Posteriormente esta discussão será apresentada com maiores detalhes.

Rochas semelhantes aos filitos hematíticos foram identificadas na região da Chapada Diamantina e estudadas por Battilani et al. (2007), sendo o grau metamórfico a maior diferença entre as duas litologias, de modo que as rochas localizadas na Chapada Diamantina atingiram no máximo o anquimetamorfismo, enquanto as rochas do Espinhaço Meridional alcançaram o grau xisto verde superior. Os autores sugerem que os diamantes sejam proximais, com duas prováveis fontes: (i) rochas ultramáficas alcalinas típicas (kimberlitos/lamproítos) como fonte de diamantes ou (ii) tais rochas compostas basicamente por sericita e óxidos de Fe/Ti (similares aos filito hematíticos). 
Segundo Dussin \& Dussin (1995) os filitos hematíticos ocorrem intercalados ou cortando a sequência basal. Ativos durante a sedimentação das formações São João da Chapada e Sopa Brumadinho, preenchem diques verticais de direção NS e EW que cortam o embasamento ou como derrames de lavas com intercalação de tufos.

Segundo Knauer \& Schrank (1993) os filitos constituem pacotes que alcançam até 30 metros de espessura. Filitos hematíticos foram incluídos em unidades mais antigas que o Supergrupo Espinhaço, tais como a Sequência Vulcano-Sedimentar Conceição do Mato Dentro (Soares Filho et al, 1986) e no Supergrupo Minas (Uhlein,1982) assim como em unidades mais recentes, como no Grupo Macaúbas (Schrank et al, 1978). Contudo, estudos realizados por Knauer (1990) e Almeida Abreu (1993) comprovam que tais filitos encontram-se exclusivamente relacionados à unidades correlatas ao Supergrupo Espinhaço. Os autores elucidam que na região central da Serra do Espinhaço Meridional os filitos associam-se mais comumente a Formação São João da Chapada, enquanto que para leste tornam-se mais comuns na Formação Sopa Brumadinho.

O livro "Diamond Deposits - Origin, Exploration, and History of Discovery" autoria de Erlich \& Hausel (2002) aborda de maneira detalhada diferentes tipos de depósitos diamantíferos. No capítulo de rochas não usuais o filito recebe destaque, em que é tratado como: “Diamondbearing phyllitic dikes appear to be widespread in the region of Diamantina, Minas Gerais Province, Brazil. These dikes appear as highly altered schistose rocks and form contacts with their hosts, and locally they cut their host rocks at acute angles. But for the most part, the dike swarms parallel the strike of the host. The dikes are composed of sericite and chlorite developed along a substratum containing relicts of porphyroblasts. The dikes form clusters oriented along the general strike of dislocated host rocks. Diamonds recovered from the phyllitic dikes are typically dodecahedral.

A suite of minerals (xenotime, zircon, magnetite, and tourmaline) in phyllitic dikes that are typically associated with granite leads to the speculation that phyllites represent altered granulites. However, some researchers assume that the Brazilian phyllites are highly altered kimberlites. Similar rocks in the Ivory Coas, Africa, are widespread and interpreted as highly altered kimberlitic dikes. The degree of diamond mineralizaton and the form of diamond crystals of the Ivory Coast intrusives are similar to those in Brazil (Zubarev, 1989). Similar intrusives may represent the original source of placer diamonds found in the Birrimian area, Ghana (Kaminsky, et al. 1998b)".

Além disto, Moraes (1934) relata detalhadamente a recuperação de diamantes a partir do filito hematítico em diversas lavras na Serra do Espinhaço Meridional, sendo notório o seguinte 
trecho: “Em 1925, Antonio Evaristo de Sousa, tendo como sócio seu sobrinho José da Costa Bruzinga, actual arrendatário da lavra, iniciou trabalhos da Serra do Pagão, explorando o “gorgulho" bruto. A exploração rendia alguma cousa, emquanto encontravam o "gorgulho" repousando no "lapeiro" sem camada de terra que o cobrisse. Exgotado esse "gorgulho”, os trabalhos proseguiram, sem resultado, numa terra amarella contendo muitos crystaes de quartzo enfumaçado. Em vista do prejuizo, Antonio Evaristo resolveu suspender o serviço, mas seu sobrinho, na esperança de mais abaixo desta terra encontrar o "gorgulho", deu um furo de 1m,0 x 1m,0, mais profundo. Não encontrando o "gorgulho”, mas sim um “giz” que ia se amolecendo a medida que se aprofundava, sem esperança alguma, "até fazendo uma besteira que podia servir de caçoada dos entendidos", por uma "bestunta”, lavou o material encontrado que "era giz puro, só com uma cangiquinha branca que ninguem dava nada por ella”; pois, "nessa coisa atôa” encontrou bem boa porção de diamantes.”

\section{5- Geologia do Diamante no Espinhaço Meridional}

A origem dos diamantes do Espinhaço Meridional ainda representa grande enigma. Derby (1879 e 1882) considerou o diamante como detrítico nos conglomerados, estando a fonte primária relacionada a veios de uma “eruptiva ácida alterada” que cortaria sua “série inferior” de xistos e quartzitos, enquanto Barbosa (1951) aceitou a gênese flúvio-glacial dos conglomerados, mas as "rochas fontes” filitizadas foram consideradas equivalentes a rochas magmáticas intermediárias.

Polêmicas e incertezas mascaram a ocorrência de diamantes na Serra do Espinhaço Meridional, de modo que controvérsias e discussões a respeito da localização da fonte primária causam conflitos de ideias entre diferentes autores.

Moraes \& Guimarães (1931) e Guimarães (1934) propuseram que os filitos hematíticos são diamantíferos e consistem na fonte primária dos diamantes. Entretanto, características intrínsecas aos diamantes, tais como sua ocorrência na forma predominante de baixa quilatagem e boa qualidade aliadas com a ausência de minerais satélites clássicos dos diamantes tanto em metaconglomerados quanto em aluviões quaternários levaram a teoria de que houve efetivo transporte sedimentar.

\subsection{1- Localização da Fonte Primária}

A respeito da localização geográfica da fonte primária dos diamantes da região, duas linhas de pensamentos são propostas por diferentes autores: (i) a rocha fonte encontra-se à oeste no 
Cráton do São Francisco sob coberturas neoproterozoicas; (ii) a rocha fonte está localizada no interior da bacia Espinhaço.

Autores como Pflug (1965), Chaves et al. (1993, 1998 e 2001) e Karfunkel \& Chaves (1995) propuseram que a rocha primária kimberlítica estaria em região cratônica à oeste do Espinhaço e atualmente recoberta pelas rochas do Grupo Bambuí. Em contrapartida, autores como Moraes \& Guimarães (1931), Moraes (1934), Barbosa (1951), Herrgesell (1984), Almeida Abreu (1996), Fleischer (1995) e Battilani et al. (2007) defendem a existência da rocha fonte no seio da bacia, intrudida nos sedimentos do Supergrupo Espinhaço.

A Tabela 2.2 traz uma síntese dos principais autores e argumentos para a determinação das fontes primárias dos diamantes da Serra do Espinhaço Meridional.

Tabela 2.2 - Autores e respectivas hipóteses sobre a origem dos diamantes.

\begin{tabular}{ll}
\hline \multicolumn{1}{c}{ Autor } & \multicolumn{1}{c}{ Fonte Externa } \\
\hline Pflug (1965) & $\begin{array}{l}\text { Kimberlitos intrudidos no Cráton do São Francisco e } \\
\text { atualmente cobertos por unidades do Supergrupo São }\end{array}$ \\
\hline Chaves et al. (1993), (1998), (2001) & \begin{tabular}{l} 
Francisco. \\
\hline Karfunkel \& Chaves (1995)
\end{tabular} \\
\hline
\end{tabular}

\begin{tabular}{ll}
\hline \multicolumn{1}{c}{ Autor } & \multicolumn{1}{c}{ Fonte Interna } \\
\hline $\begin{array}{l}\text { Moraes \& Guimarães (1931)/ Moraes } \\
\text { (1934) }\end{array}$ & $\begin{array}{l}\text { Filitos como rocha fonte, com relatos da recuperação } \\
\text { de diamantes a partir de tal rocha. }\end{array}$ \\
\hline Barbosa (1951) & Filitos hematíticos e cloríticos. \\
\hline Herrgesell (1984) & Rocha fonte localizada no interior da bacia. \\
\hline Almeida Abreu (1993), (1996) & $\begin{array}{l}\text { Filitos como rocha primária e metabrecha quartzítica } \\
\text { resultado de trabalhamento de vent breccia. }\end{array}$ \\
\hline Fleischer (1998) & $\begin{array}{l}\text { Possíveis fontes kimberlíticas/lamproíticas em } \\
\text { diferentes pulsos. }\end{array}$ \\
\hline Battilani et al. (2007) & $\begin{array}{l}\text { Rochas fonte no interior da bacia Espinhaço } \\
\text { (Kimberlitos/lamproítos ou o filito hematítico). }\end{array}$ \\
\hline
\end{tabular}

\subsubsection{1 - Diamante com Fonte Distal}

Pflug $(1965,1968)$ definiu que as rochas diamantíferas intercalam-se estratigraficamente na sequência quartzítica da serra, pelos vetores das paleocorrentes, definiu-se um aporte sedimentar de oeste para leste. Considerando a existência de uma área-fonte a oeste, e como esta área cratônica foi a supridora de sedimentos para a Bacia Espinhaço, deveriam existir rochas de natureza básica-ultrabásica, fontes primárias dos diamantes. Durante o Neoproterozoico, a zona cratônica sofreu subsidência, recebendo a cobertura sedimentar do Grupo Bambuí. 
Características intrínsecas às ocorrências dos diamantes são abordadas por Chaves et al. (1998) para evidenciar fonte distal. Os autores destacam que sendo a fonte primária dos diamantes rochas ultramáficas convencionais, as mesmas já teriam sido descobertas pela intensa atividade de campanhas de exploração realizadas. Além disto, os minerais satélites kimberlíticos clássicos (granada piropo, ilmenita e espinélio) não ocorrem associados aos metaconglomerados ou dispersos no sistema de drenagens, ou seja, em caso de ausência de minerais satélites os diamantes apresentam, teoricamente, caráter distal.

Além disto, os autores relatam que os diamantes são em sua maioria de baixa quilatagem e boa qualidade, o que seria resultado de um efetivo selecionamento dos cristais. Tal selecionamento seria consequência de transporte e distanciamento da área fonte, de modo que os diamantes industriais (lascas/fragmentos) possuem menor potencial hidrodinâmico e são destruídos com maior facilidade. Outro ponto levantado por Chaves et al. (1998) consiste no fato de que, segundo os garimpeiros, todos os conglomerados são mineralizados, caso a fonte fosse proximal, seria coerente a existência de conglomerados diamantíferos e estéreis.

De acordo com Chaves et al. (1997), antes do processo de rifteamento rochas de provável afinidade kimberlítica intrudiram a crosta superior em áreas à oeste do Espinhaço. Os clastos presentes nos metaconglomerados exibem predominância de rochas sedimentares com menor contribuição de clastos de rochas ígneas ou metamórficas, contudo não foi recuperado nenhum mineral indicador de rocha primária. Chaves et al. (2001) atentam-se para o ambiente tectônico, uma vez que as rochas diamantíferas limitam-se às áreas cratônicas. As idades de zircões presentes nos conglomerados fornecem valores de 3.6, 2.8 e $2.0 \mathrm{Ga}$, o que representa a idade de rochas cratônicas, contudo não é possível correlacionar com a idade da rocha fonte de diamantes.

\subsubsection{2- Diamante com Fonte Proximal}

Moraes \& Guimarães (1931) e Moraes (1934) acreditam ter encontrado a rocha fonte a partir da recuperação de diamantes a partir de filitos hematíticos. Em contrapartida, Chaves et al. (1985) acreditam que a ocorrência de metabrechas na região indica que o material lavrado era na verdade do tipo coluvionar.

A origem proximal para os diamantes da Serra do Espinhaço Meridional elucida que as rochas primárias foram drasticamente deformadas e, devido à sua reologia, atualmente encontramse dispostas como corpos estirados. Outro ponto ressaltado consiste na recristalização da assembleia mineralógica das rochas em detrimento do metamorfismo regional, o que desta forma impossibilita a recuperação de tais minerais, tanto em rocha, quanto em ambiente aluvionar. 
Outro argumento utilizado refere-se ao fato do campo diamantífero de Extração, que se encontra desalinhado e à leste das demais ocorrências, possuir os maiores diamantes já recuperados na região. Se o fluxo sedimentar que alimentou a bacia com os diamantes possuía sentido de oeste para leste, ou seja, do cráton para a bacia, não faria sentido os maiores diamantes ocorrerem em Extração, como observado por Almeida Abreu (1996).

Almeida Abreu (1996) em sua obra “O caminho das pedras” defende que a rocha fonte dos diamantes não se encontra somente no seio da bacia, mas, sobretudo, nas proximidades dos depósitos metassedimentares mineralizados. Ao descrever a metabrecha, o autor afirma que não há qualquer processo geológico capaz de explicar o transporte superior a alguns metros ou poucas dezenas de metros, logo considerar a metabrecha quartzítica como resultado de retrabalhamento de vent breccia é fundamentado não somente na presença dos diamantes, mas também na semelhança com depósitos de hidrovulcanismo do lamproíto Ellendale. A formação de crateras tipo Maar é denunciada pela geometria e extensão dos depósitos do Membro Campo Sampaio (Almeida Abreu, 1993), sendo os pelitos em sua maioria resultado do retrabalhamento intempérico e sedimentar dos depósitos de lappilli e cinzas vulcânicas.

Também é levantado o fato de que os diamantes da região de Diamantina podem ser classificados por populações de acordo com a área de origem, ou seja, os diamantes provenientes de cada campo diamantífero possuem características próprias que os diferem dos diamantes de demais localidades. Esta particularidade corrobora a existência de fontes proximais, pois, em caso de fontes distais, o esperado seria ocorrer a homogeneização dos cristais de forma que impossibilitaria a distinção de populações. Outro ponto que merece ser acentuado consiste na ausência de feições que refletem transporte sedimentar, como será discutido no decorrer deste trabalho. A Tabela 2.3 apresenta uma síntese argumentos pró- fontes proximais e distais.

Tabela 2.3 - Resumo dos argumentos para fonte distal e proximal dos diamantes da região do Espinhaço Meridional.

\begin{tabular}{ll}
\hline Indícios Fonte Distal & Indícios Fonte Proximal \\
\hline $\begin{array}{l}\text { Ausência dos minerais satélites clássicos dos } \\
\text { diamantes. }\end{array}$ & $\begin{array}{l}\text { Caráter particular dos diamantes de cada } \\
\text { campo diamantífero. }\end{array}$ \\
\hline $\begin{array}{l}\text { Os diamantes são em sua maioria de baixa } \\
\text { quilatagem e de boa qualidade. }\end{array}$ & $\begin{array}{l}\text { Diamantes do campo de Extração, área mais } \\
\text { oriental, consistem nos maiores diamantes } \\
\text { recuperados. }\end{array}$ \\
\hline $\begin{array}{l}\text { Todos os metaconglomerados são } \\
\text { diamantíferos. }\end{array}$ & $\begin{array}{l}\text { Registros de lavra e recuperação de diamantes } \\
\text { a partir do filito hematítico. }\end{array}$ \\
\hline $\begin{array}{l}\text { Fontes primárias ocorrem preferencialmente } \\
\text { em áreas cratônicas. }\end{array}$ & $\begin{array}{l}\text { Diamantes sem feições de transporte } \\
\text { sedimentar. }\end{array}$ \\
\hline
\end{tabular}




\section{CAPÍTULO 3}

\section{GEOLOGIA LOCAL}

Este capítulo particulariza as unidades diamantíferas que ocorrem na região de Diamantina assim como as lavras visitadas durante a realização deste trabalho. Inicialmente, os tipos de depósitos serão descritos quanto às suas principais peculiaridades e possíveis implicações para a presença de diamantes assim como relações existentes com os filitos hematíticos. Em seguida, as lavras visitadas serão caracterizadas quanto à ocorrência destas unidades mineralizadas em diamante com ênfase para os filitos hematíticos. Os filitos hematíticos afloram preferencialmente na Formação Sopa Brumadinho. A Figura 3.1 ilustra as relações estratigráficas propostas neste trabalho ressaltando a presença dos filitos que são concordantes ou discordantes de diferentes rochas da Formação Sopa Brumadinho.

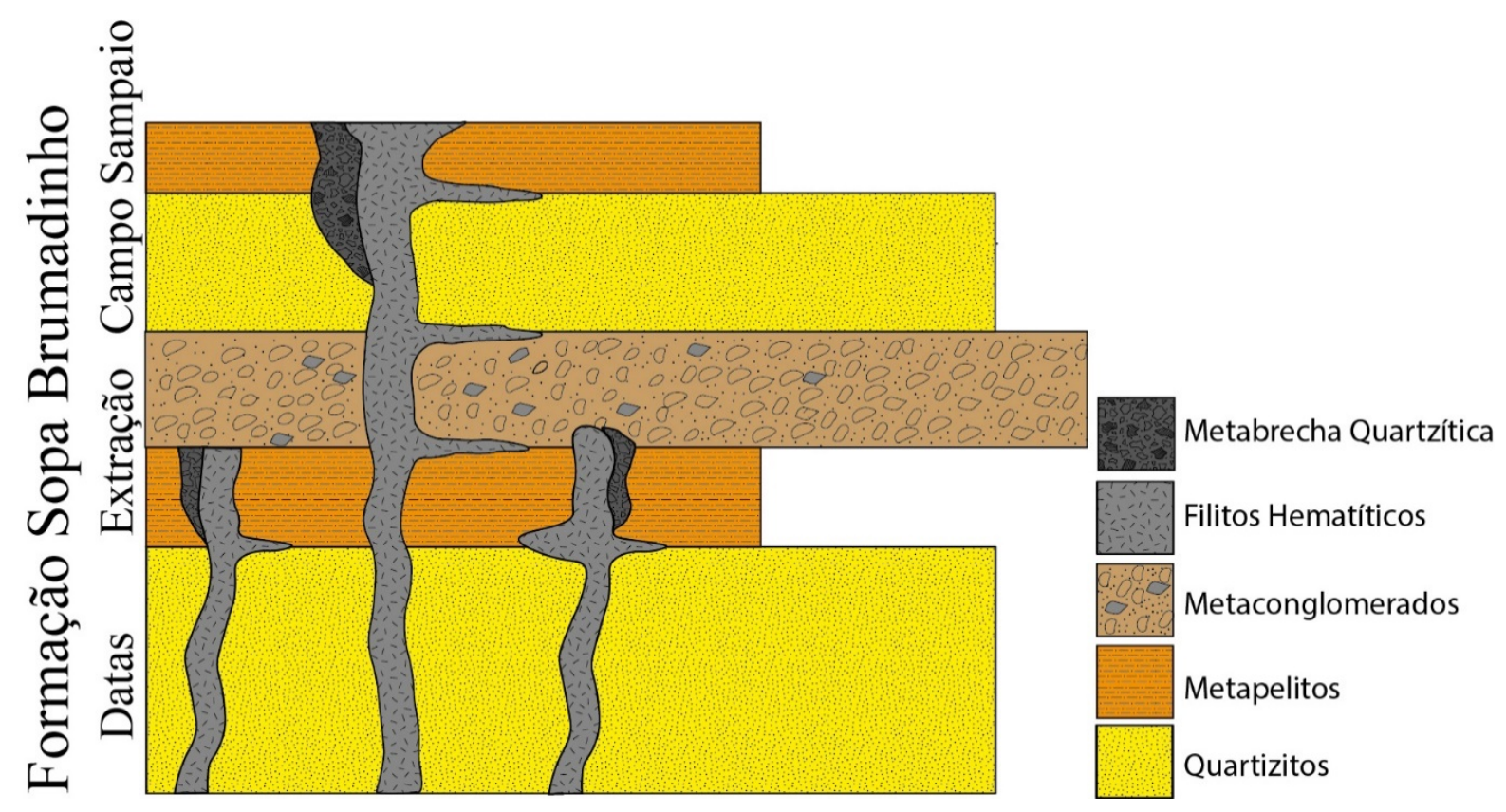

Figura 3.1 - Carta estratigráfica da Formação Sopa Brumadinho destacando as unidades diamantíferas: Metaconglomerados, filitos hematíticos e metabrecha quartzítica.

A utilização indiscriminada de termos tais como "filito" ou "filito hematítico" acarreta imprecisão, de modo que qualquer rocha pelítica com grau metamórfico xisto verde muitas vezes é denominada filito hematítico. Da mesma forma que critérios são utilizados na diferenciação dos termos quartzíticos, os filitos apresentam feições que permitem classificar quanto a sua origem.

A princípio foram identificados dois grupos principais de filitos presentes na sequência da Serra do Espinhaço Meridional: (i) filito hematítico de origem ígnea e (ii) filito sericítico de origem sedimentar. 
O filito sericítico consiste de rochas de coloração prateada, homogêneas e monótonas em relação a presença de nódulos de óxidos ou demais minerais, e tem sua ocorrência de forma concordante e comumente exibe crenulações características (Figuras 3.2 e 3.3). Pode ser facilmente diferenciado do filito ígneo pelo seu brilho sedoso proeminente, contudo as rochas nem sempre apresentam fácil diferenciação. Os filitos sericíticos apresentam ampla distribuição na Formação Sopa Brumadinho e, não raramente, ocorrem associados espacialmente com os filitos hematíticos. Este litotipo quando alterado aflora na forma friável de coloração esbranquiçada, recorrente principalmente nas proximidades do povoado Sopa, oeste de Diamantina. Desta forma, é importante diferenciar o filito sericítico, sedimentar e não diamantífero, do filito hematítico, ígneo e potencialmente diamantífero.

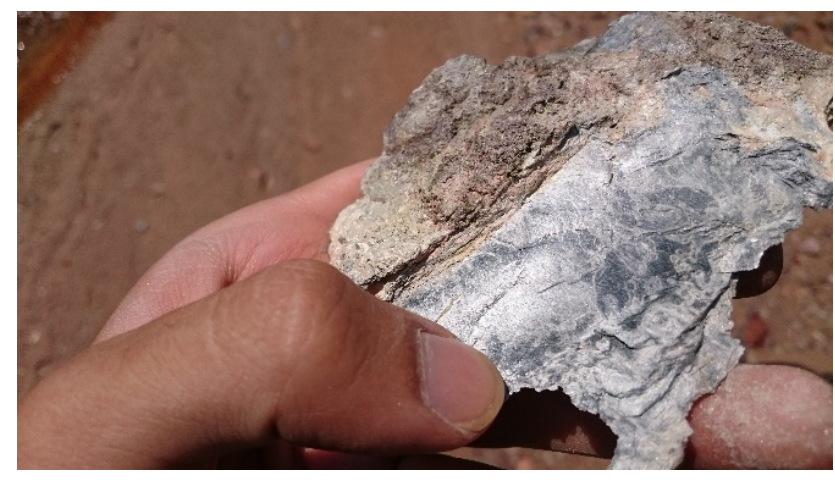

Figura 3.2 - Filito sericítico com brilho e coloração característicos.

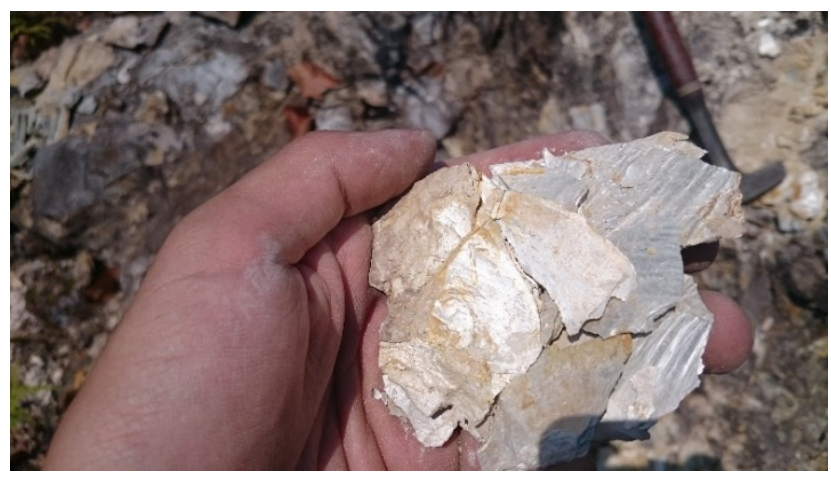

Figura 3.3 - Filito sericítico exibindo crenulação característica de filito de origem sedimentar.

\section{1- Ocorrências de Diamantes na Serra do Espinhaço Meridional}

O diamante ocorre em diferentes litologias na Serra do Espinhaço Meridional, o que corrobora com a abundância do mineral na região. Apesar de representar a forma mais difundida, a ocorrência não se encontra restrita aos metaconglomerados proterozoicos, uma vez que as metabrechas quartzíticas, crostas lateríticas, filito hematítico e ambientes aluvionares/coluvionares são alvos recorrentes de garimpo.

\subsection{1- Filito Hematítico}

O filito hematítico consiste no objeto principal de estudo deste trabalho. Diversos relatos e indícios de campo evidenciam a mineralização destas rochas em diamante. Em campo observa-se que a rocha exibe ampla variedade textural, de modo que ocorrem diferenças abruptas de textura. A ocorrência mais comum, ou seja, o filito hematítico "típico” consiste em rocha de cor cinza acompanhada por concentrações de óxidos (hematita), eventualmente contendo turmalina e pseudomorfos tabulares. 
A variedade de texturas observadas durante a realização deste trabalho assemelha-se com as descritas por Schöll \& Fogaça (1981). Tal variedade esclarece as heterogeneidades da rocha original, como ilustrado nas Figuras 3.4 a 3.7. Localmente, a rocha aflora com nódulos centimétricos de óxidos, formando uma textura peculiar característica, interpretada por Schöll \& Fogaça (1981) como prováveis relictos de pillow lavas (Figura 3.8). Quando se encontra em elevado grau de alteração, a rocha aflora de forma friável de coloração rósea avermelhada (Figura 3.9). Outra ocorrência, porém restrita, consiste de uma rocha escura com textura brechoidal, corroborando seu carácter ígneo explosivo, esta textura será mais bem ilustrada nas descrições das lavras visitadas. De forma isolada, sobretudo nas proximidades da lavra Caldeirões, o filito hematítico apresenta coloração esverdeada, tendo sido verificado em lâmina que tal coloração é derivada da presença abundante de clorita.

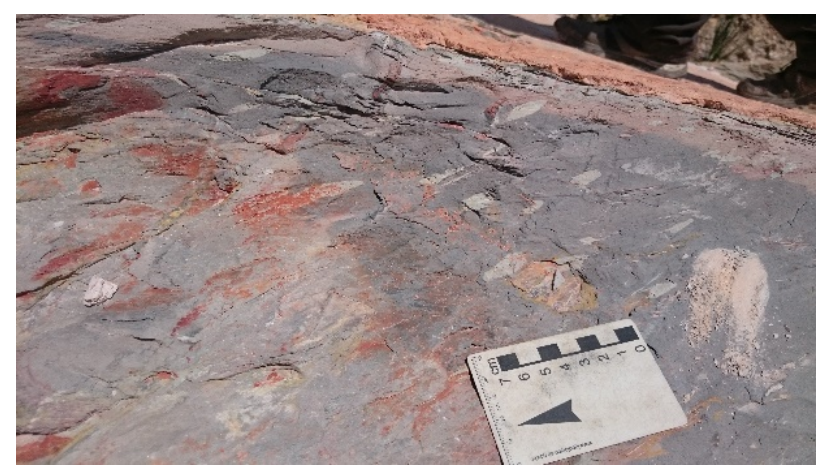

Figura 3.4 - Filito hematítico com manchas derivadas da alteração diferencial.

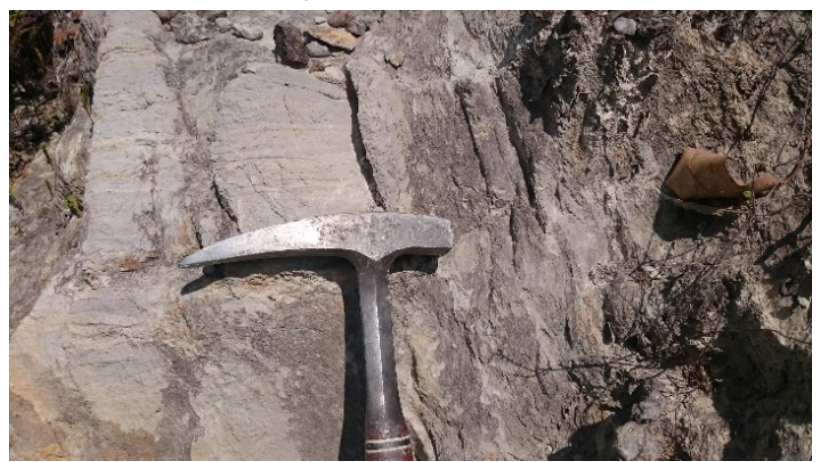

Figura 3.6 - Filito hematítico com ausência de concentrações de óxidos.

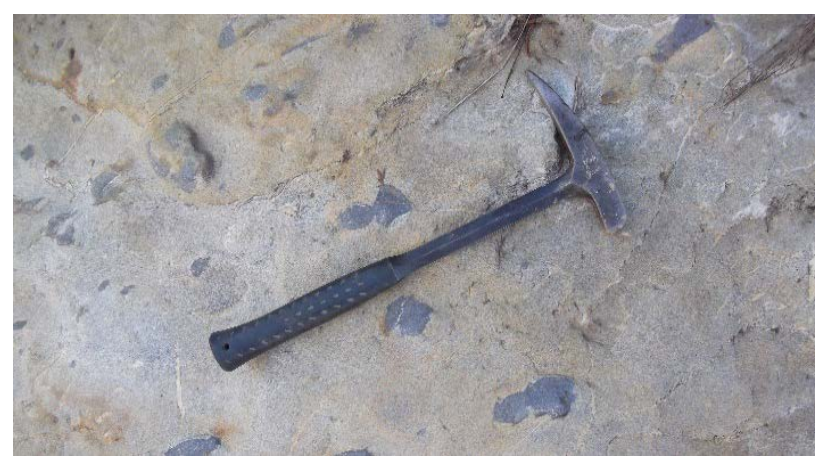

Figura 3.8 - Filito hematítico exibindo nódulos centimétricos de óxido de ferro e turmalina.

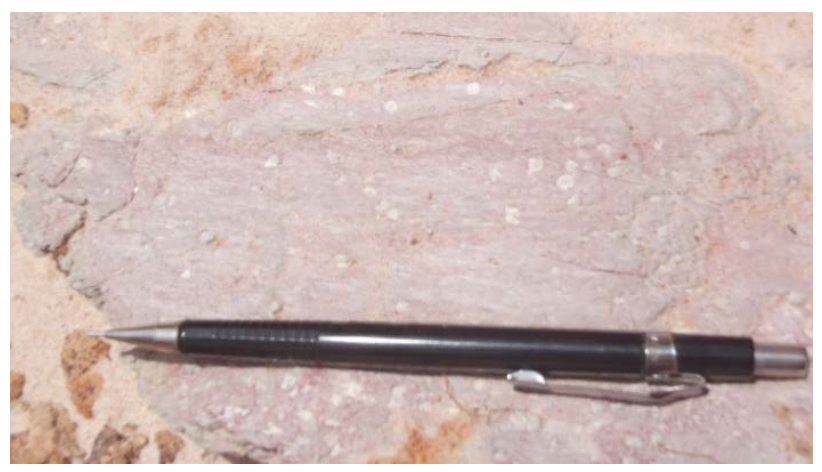

Figura 3.5 - Filito hematítico com paseudormorfos sericitizados.

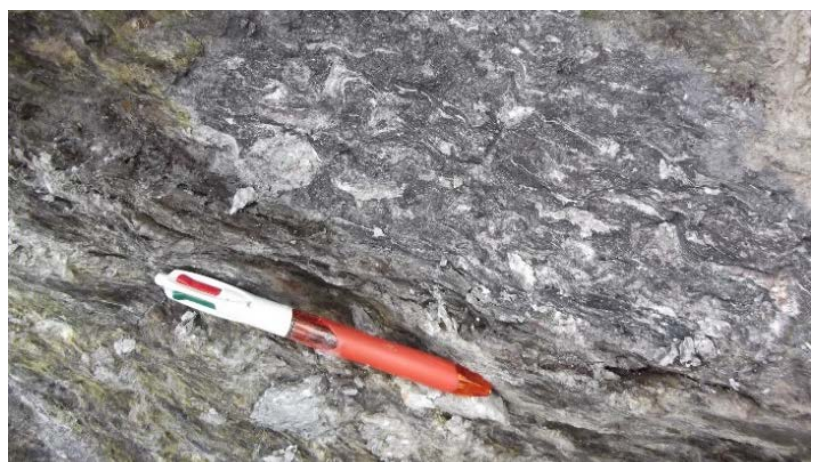

Figura 3.7 - Filito hematítico com níveis de sericita intercalados com níveis de óxidos.

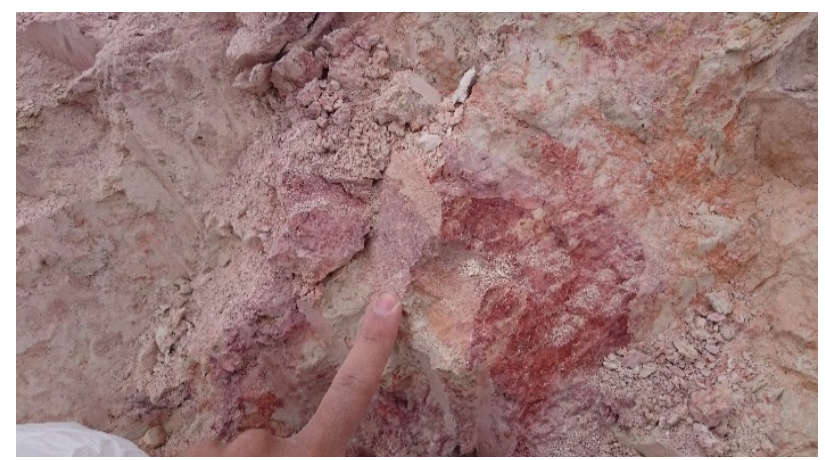

Figura 3.9 - Filito hematítico em elevado grau de alteração apresentando coloração rosada. 
O filito hematítico aflora, preferencialmente, como cristas verticalizadas orientadas N-S, por vezes em nítida discordância com as demais unidades. Rochas recorrentes na Serra do Espinhaço Meridional, os filitos hematíticos afloram nas proximidades de todas as lavras visitadas neste trabalho, não raramente com evidências de atividade garimpeira sobre a rocha, que recebe localmente a denominação de “giz”. Análises petrográficas, geoquímicas e geocronológicas foram realizadas nos filitos hematíticos, sendo os resultados discutidos no decorrer deste trabalho.

\subsection{2 - Metaconglomerado}

Os metaconglomerados (Figura 3.10) são rochas diamantíferas e alvo recorrente de atividade garimpeira. São em sua em sua maioria clasto-suportados com matriz arenosa, e os clastos são maioritariamente de quartzitos, subordinadamente ocorrem clastos de filitos hematíticos e demais litologias. Clastos de filitos hematíticos são nitidamente angulosos em comparação com os demais, tais filitos afloram nas adjacências dos metaconglomerados, preferencialmente à oeste, uma vez que o aporte sedimentar foi de oeste para leste, o filito participou ativamente durante o desenvolvimento dos leques aluvionares. As ocorrências de metaconglomerados da Formação Sopa Brumadinho são orientados segundo a direção NNW-SSE, com exceção das lavras do campo diamantífero de Extração, que se encontram à leste do alinhamento. As lavras de metaconglomerados foram viáveis devido ao elevado grau de alteração das rochas, facilitando o desmonte hidráulico. Os metaconglomerados litificados são chamados de “massa gelada” e em sua maioria permanecem intactos.

Ocorrem como corpos lenticulares e, como destacado por Chaves (1997) o Conglomerado Sopa, aflora em uma faixa linear de aproximadamente $100 \mathrm{~km}$ de comprimento N-S, coincidente com a porção axial da cordilheira, fato este que explica a notável distribuição aluvionar cenozoica dos depósitos diamantíferos.

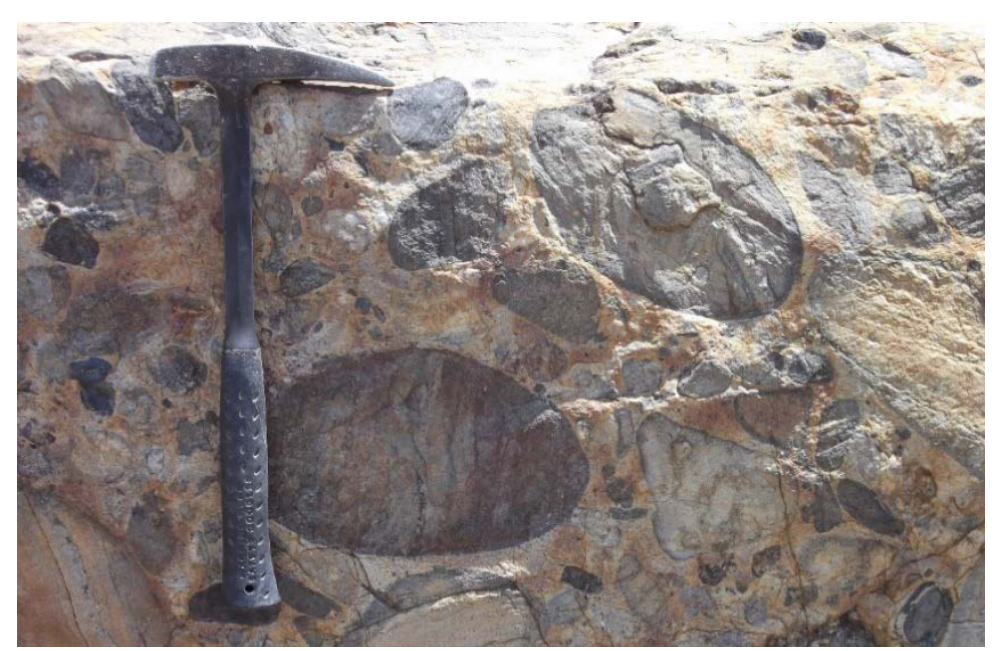

Figura 3.10 - Metaconglomerado litificado localizada na lavra Lavrinha, próximo ao povoado Guinda. 


\subsection{3 - Metabrecha Quartzítica}

Um segundo litotipo controverso, da mesma maneira que os filitos hematíticos, porém já consagrado como diamantífero, consiste nas metabrechas quartzíticas. A origem da rocha apresenta interpretações distintas na literatura, de modo que Draper (1920, 1923), Moraes \& Guimarães (1930) e Almeida Abreu (1996) as descrevem como brechas eruptivas, enquanto Kerr et al. (1941), Pflug (1965b), Chaves et al. (1985) e Dossin et al. (1985) como brechas de origem sedimentar, sobretudo devido à ocorrência de clastos subarredondados. Seguindo o mesmo raciocínio, Chaves \& Uhlein (1991) postularam que as metabrechas quartzíticas são resultado de fluxos gravitacionais do tipo debris flow. Enquanto isso, Almeida Abreu (1996) relata que é desconhecido processo geológico capaz de retrabalhar os fragmentos da metabrecha a distâncias maiores que poucos metros, bem como seus diamantes. Logo, o autor sugere que considerar a metabrecha quartzítica como retrabalhamento de vent breccia é substanciado não apenas nas suas características e na mineralização em diamante, mas também pela semelhança com depósitos de hidrovulcanismo do lamproíto de Ellendale.

No âmbito dos garimpos, tanto os metaconglomerados, quanto as metabrechas quartzíticas recebem a denominação de "massa”, sendo os dois tipos alvos de lavra. A metabrecha quartzítica é composta por fragmentos angulosos a subangulosos de quartzitos inseridos em matriz pelítica. Em campo, foi verificado que sua ocorrência está rigorosamente relacionada com a presença dos filitos hematíticos, estes que por sua vez representam o material que compõe a matriz da metabrecha quartzítica. Deste modo, a gênese da rocha é resultado da brechação por pressão de fluídos durante o emplacement da rocha precursora dos filitos hematíticos. Seguindo tal raciocínio, a metabrecha quartzítica, representada pelo membro Campo Sampaio da Formação Sopa Brumadinho, apresenta feições que a definem como resultado da interação do magma, explosivo e rico em voláteis, com as rochas encaixantes.

Uma característica relevante intrínseca às metabrechas quartzíticas consiste no fato de que sua ocorrência, além de estar relacionada aos filitos hematíticos, é restrita aos locais em estes formam pipes, ou seja, em corpos de maiores dimensões, sendo desconsiderável sua ocorrência em diques e corpos menores. Tal fato explica a relação de sua gênese com o vulcanismo associado, uma vez que intrusões de maior porte tendem a ser mais explosivas e possibilitar maior interação com as rochas encaixantes, no caso, rochas quartzíticas das unidades subjacentes. Ótimos exemplos de metabrechas quartzíticas podem ser observados nas lavras Caldeirões e Colônia.

Na lavra Caldeirões, a metabrecha quartzítica aflora nas paredes da depressão aberta pelo garimpo de forma friável com coloração rosada (Figura 3.11). A rocha ocorre preferencialmente 
sem foliação, porém zonas deformadas ocorrem pontualmente, compostas exclusivamente pelo filito hematítico. Tais zonas podem ser interpretadas como pequenas injeções de filito hematítico que seccionam a metabrecha (Figura 3.12). Os fragmentos de quartzito que compõem a metabrecha apresentam-se tanto angulosos quanto subarredondados (Figura 3.13) assim como faixas decimétricas estiradas (Figura 3.14). Atividade garimpeira na lavra foi realizada manualmente por décadas, sendo relatada a retirada de grande quantidade de diamantes do local, sobretudo da metabrecha. Porém, o filito hematítico e a metabrecha quartzítica são lavrados simultaneamente por desmonte hidráulico, logo na o há como definir com precisão qual rocha forneceu os diamantes.

Na porção superior leste da lavra Caldeirões, a área elevada é constituída exclusivamente pelo filito hematítico. Em porção adjacente ocorre uma pequena escavação em que é possível identificar a metabrecha quartzítica (Figura 3.15) imediatamente abaixo do filito, desta forma, quando a metabrecha quartzítica encontra-se em menor grau de alteração, sua matriz ocorre de forma idêntica ao filito hematítico. Localmente, demais rochas podem ser identificadas no filito hematítico devido à alteração diferencial, tanto fragmentos de quartzitos (Figura 3.16) quanto de filitos.

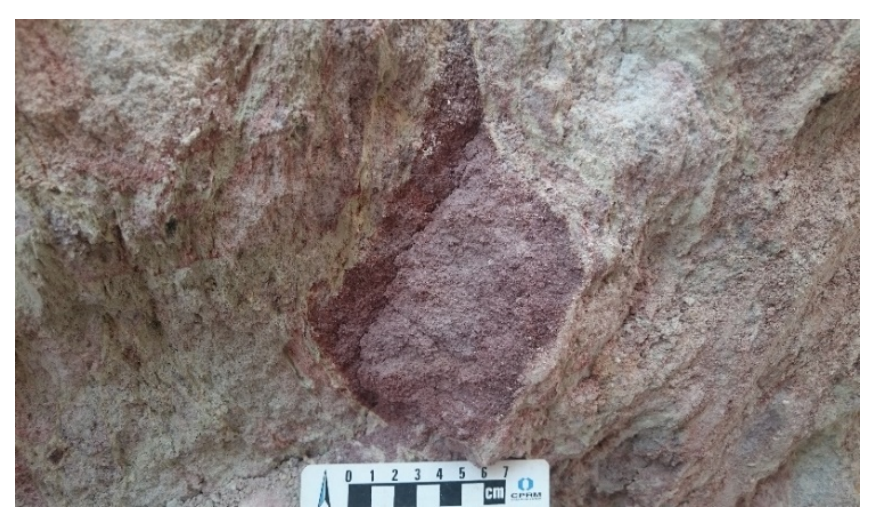

Figura 3.11 - Detalhe da metabrecha quartzítica com fragmento anguloso de quartzito no centro.

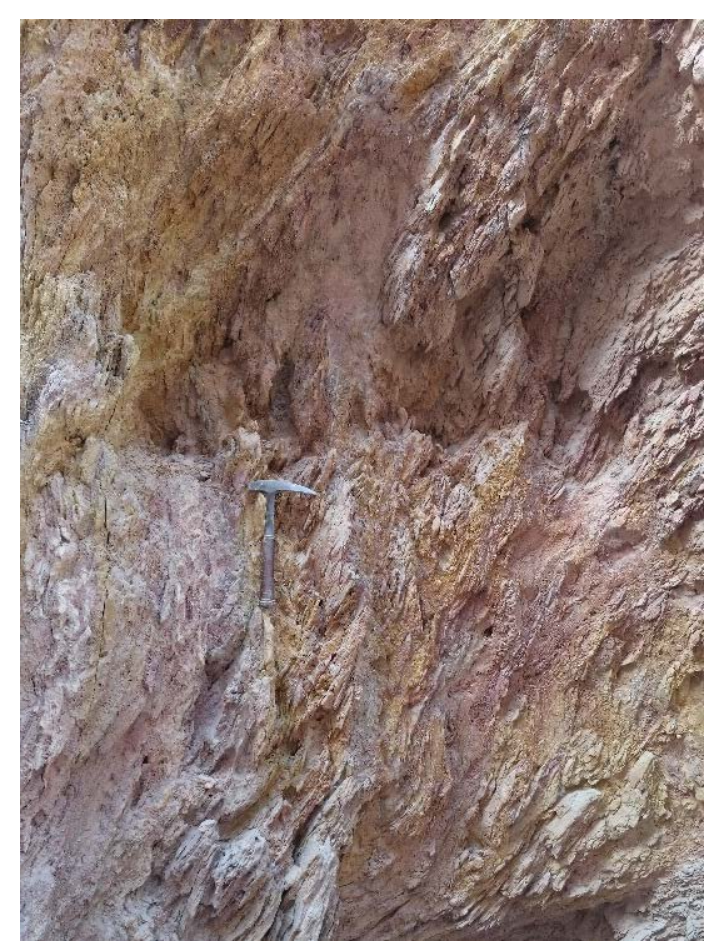

Figura 3.12 - Zonas de maior deformação localizadas no interior da metabrecha quartzítica. 


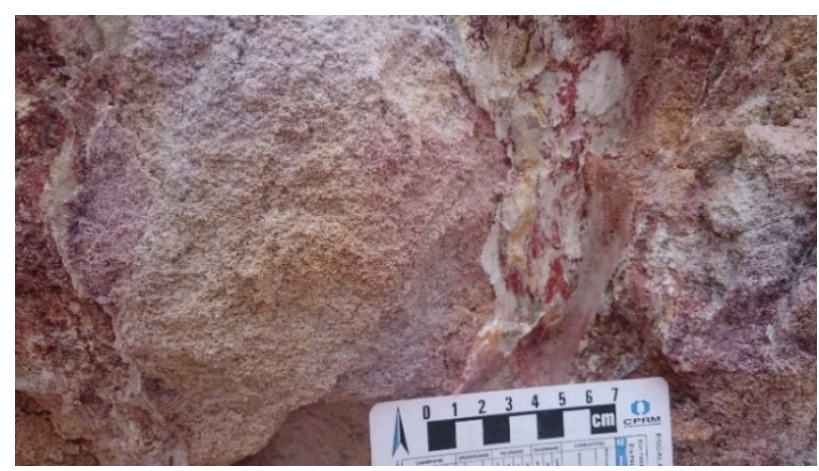

Figura 3.13 - Fragmento subarredondado de quartzito envolto matriz pelítica.

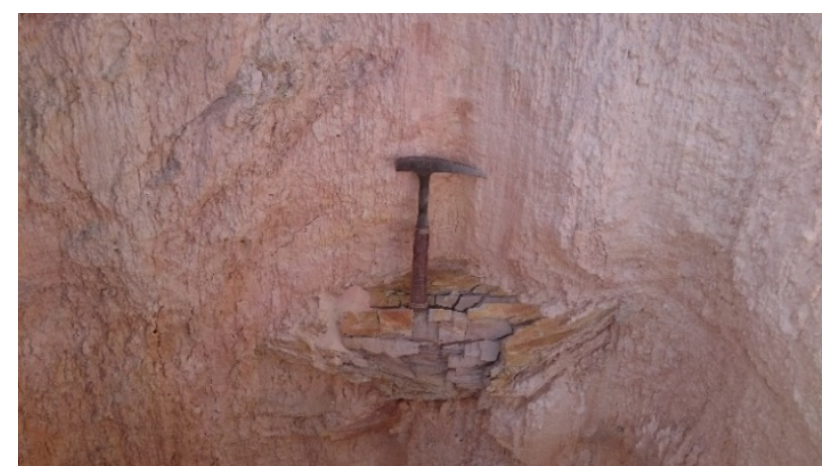

Figura 3.15 - Fragmento de filito no interior da metabrecha quartzítica, imediatamente acima aflora o filito hematítico.

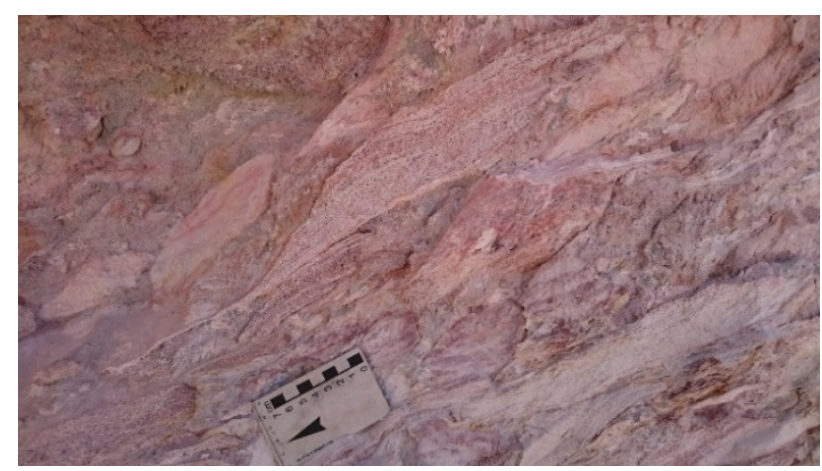

Figura 3.14 - Metabrecha quartzítica exibindo fragmentos estirados de quartzito.

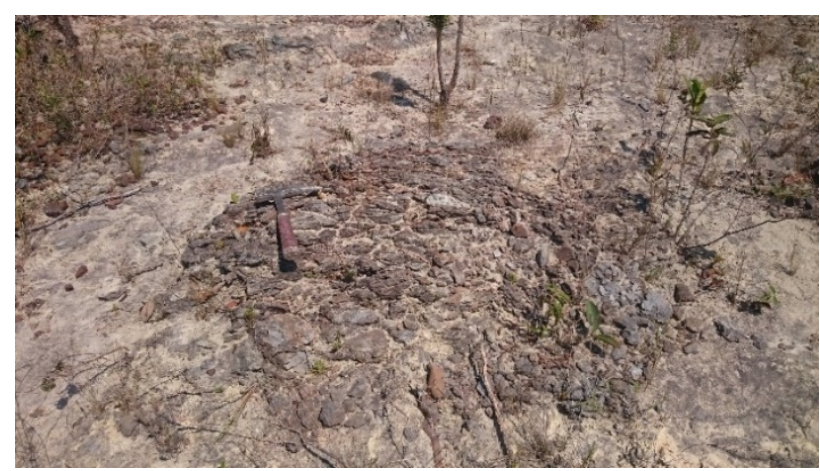

Figura 3.16 - Alteração diferencial de quartzito inserido na metabrecha quartzítica/filito hematítico.

Seguindo o mesmo raciocínio, o filito hematítico quando alterado aflora com textura idêntica à matriz da metabrecha quartzítica, única diferença consiste na ausência dos fragmentos de quartzito. A metabrecha quartzítica ocorre preferencialmente na forma alterada, sendo assim o processo de gênese da metabrecha confere maior porosidade à rocha, o que favorece a percolação de fluídos e consequente alteração, tanto da metabrecha quartzítica, quanto do filito hematítico adjacente.

Na lavra Colônia, afloramentos discretos da metabrecha quartzítica (Figura 3.17) ocorrem em níveis cuja matriz, ou seja, o filito hematítico entre os fragmentos de quartzitos não se encontra alterado, mantendo sua feição típica (Figura 3.18), enquanto filitos hematíticos típicos afloram adjacentes à rocha. Desta forma, é coerente e incontestável que exista relação entre as duas litologias, sendo a metabrecha quartzítica composta por filito hematítico acompanhado de fragmentos de quartzitos assimilados durante a ascensão do magma. 


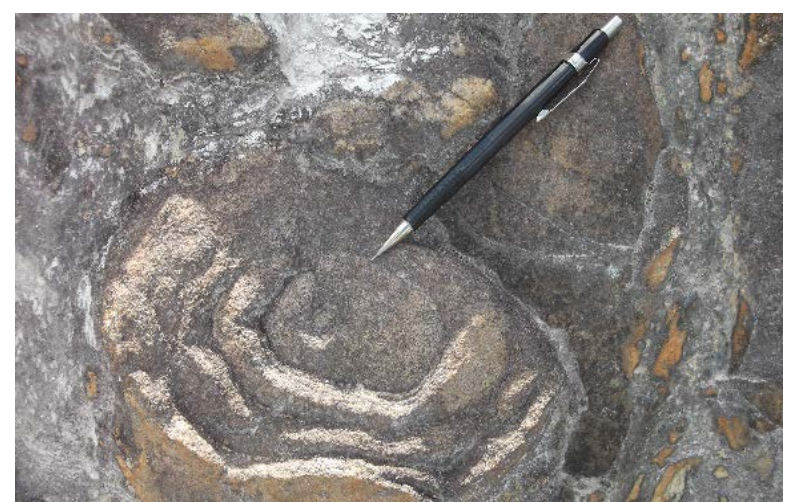

Figura 3.17 - Metabrecha quartzítica litificada aflorante na lavra Colônia.

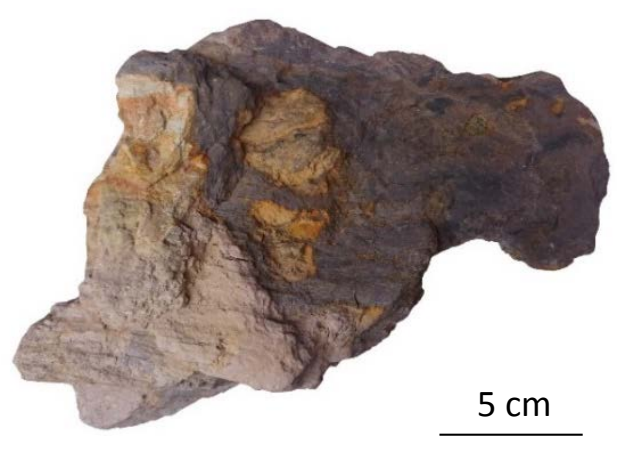

Figura 3.18- Detalhe para o filito hematítico que compõe a matriz da metabrecha quartzítica aflorante na lavra Colônia.

\subsection{4 - Crostas Lateríticas (Gorgulho)}

O material detrítico diamantífero denominado "gorgulho” é conhecido desde 1825, conforme menção do Dr. Joaquim Felício dos Santos (Moraes, 1934). O gorgulho é derivado do processo de lateritização do filito hematítico ou metaconglomerado, formando crostas ferruginosas diamantíferas. Em diversos pontos, principalmente em áreas de garimpo, é possível observar perfil de pedogênese do filito hematítico evidenciando formação de gorgulho (Figuras 3.19 e 3.20).

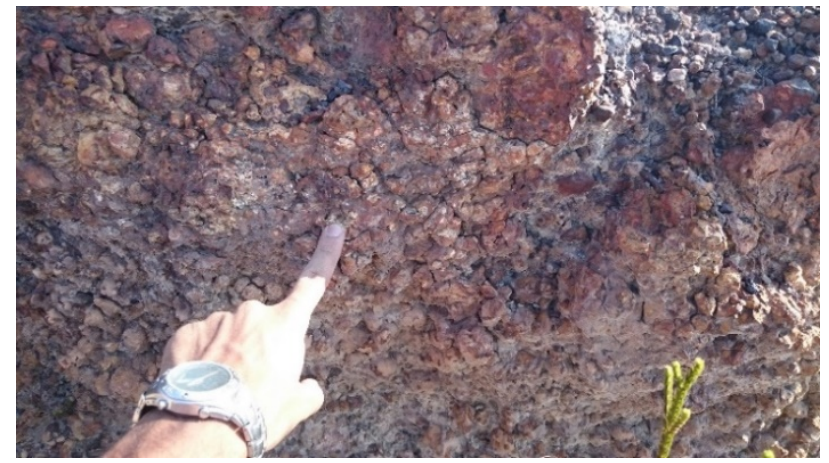

Figura 3.19 - Perfil de alteração do filito hematítico na lavra Caldeirões.

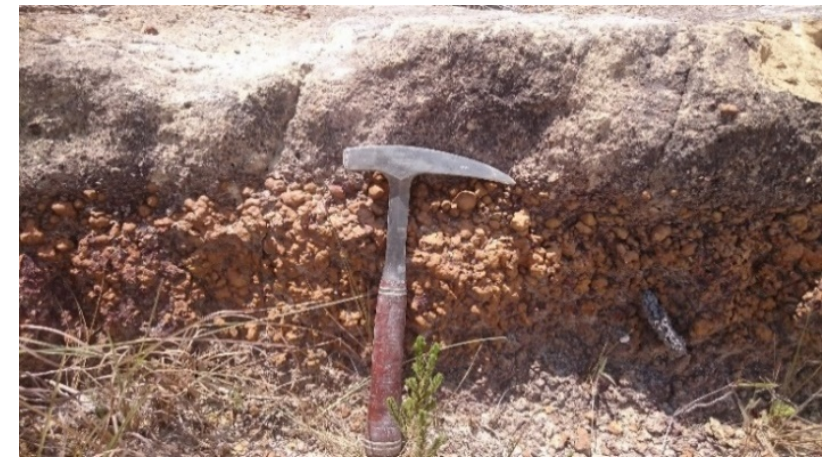

Figura 3.20 - Perfil de alteração do filito hematítico no Povoado Sopa.

De forma pertinente, todo o percurso entre as lavras Caldeirões e Eminosa se dá sobre o filito hematítico (Figura 3.21), local em que ocorre considerável quantidade de gorgulho lavrado na forma de grandes amontoados (Figuras 3.22 a 3.24). Inclusive, há ocorrência de uma antiga estação de tratamento do gorgulho (Figuras 3.25 e 3.26), o que evidencia intensa lavra assim como considerável potencial diamantífero. O gorgulho possui coloração marrom avermelhada, constituído por óxidos de ferro com eventuais fragmentos angulosos de quartzo (Figura 3.27). Existem relatos de que, por vezes, diamantes ocorrem encravados no gorgulho, considerando que 
o material não é totalmente triturado, é possível que ainda existam diamantes no interior das crostas lateríticas lavradas.

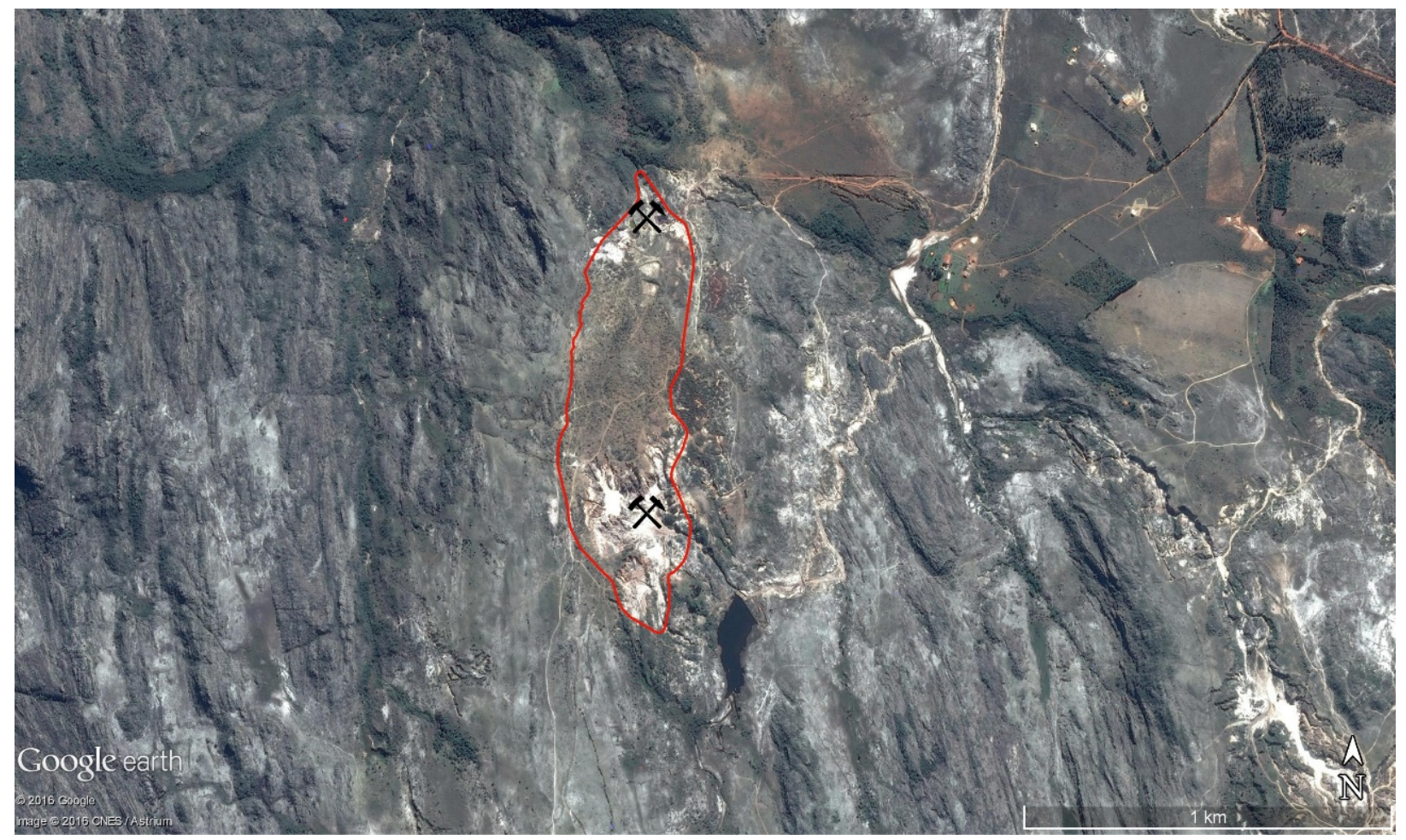

Figura 3.21 - Imagem de satélite ilustrando ocorrência de filito hematítico e gorgulho, desde a lavra Caldeirões ao norte à antiga lavra da Eminosa à sul.
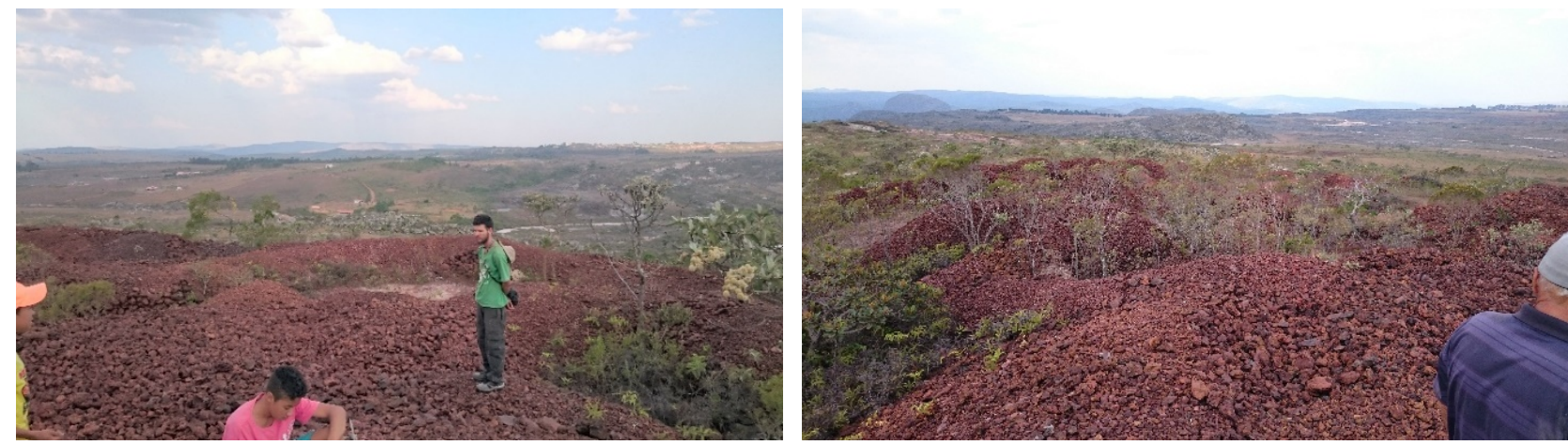

Figuras 3.22 e 3.23 - Amontoados de gorgulho tratados para recuperação de diamantes.

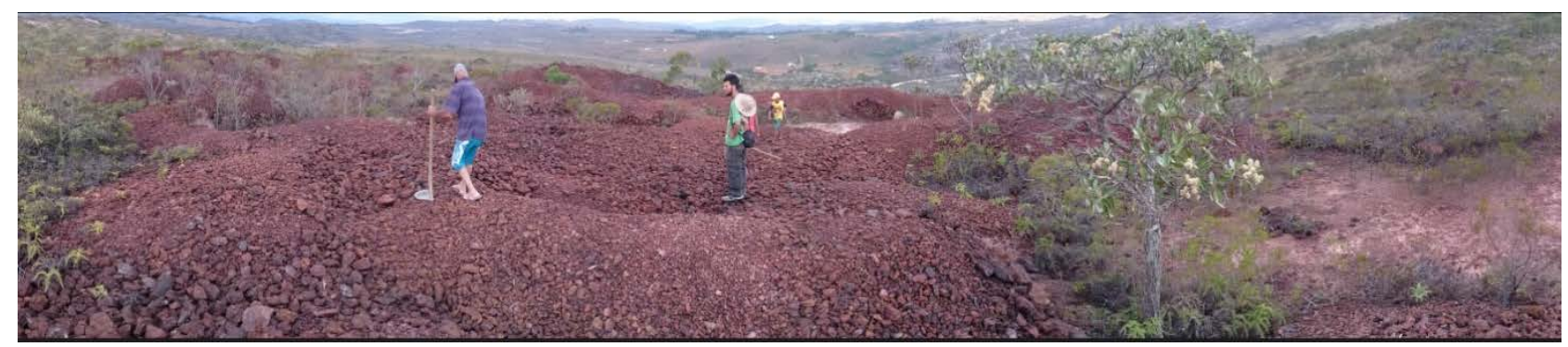

Figura 3.24 - Foto panorâmica da abundante concentração de gorgulho lavrado. 

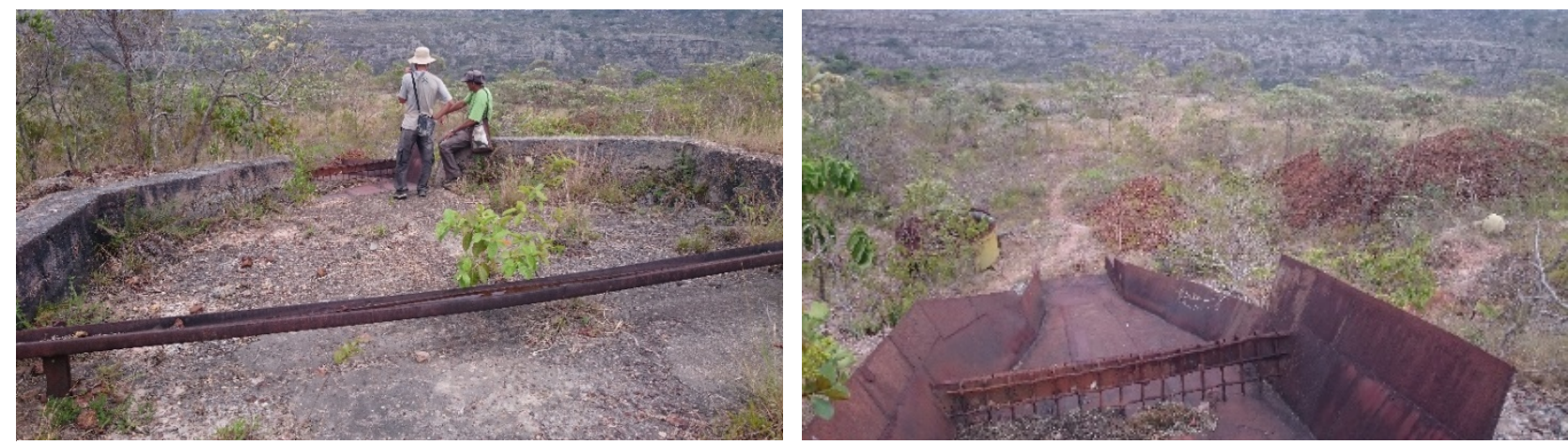

Figuras 3.25 e 3.26 - Antiga estação de lavra do gorgulho, localizada próxima à lavra Eminosa.

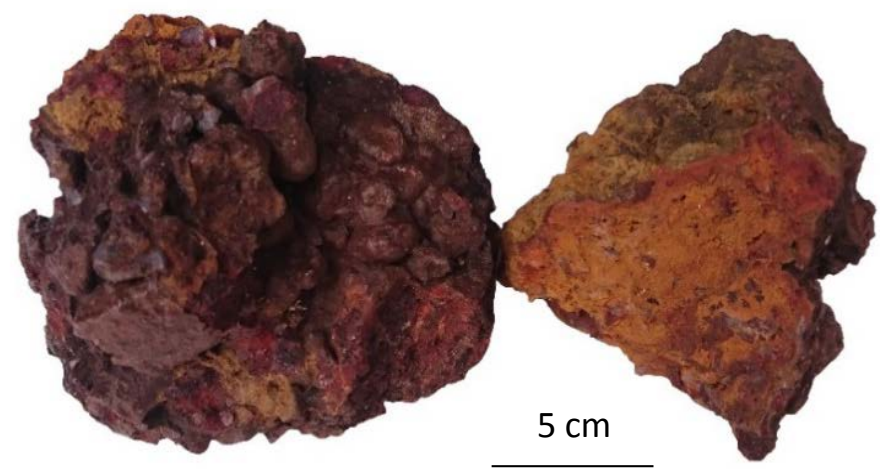

Figura 3.27 - Amostra do gorgulho evidenciando as principais características da rocha, destaque para seu aspecto concrecionário e brechoidal.

Na lavra Lavrinha o gorgulho ocorre como alteração do metaconglomerado, com evidências claras de atividade garimpeira sobre o material laterítico, porém, o gorgulho resultado da alteração do metaconglomerado apresenta diferenças particulares do proveniente do filito hematítico, sendo mais grosso, com coloração mais avermelhada e maior quantidade de quartzo.

Durante o processo de alteração do filito hematítico concentram-se os minerais residuais, tais como óxidos, quartzo e eventualmente o diamante. Desta maneira, é coerente que a concentração de diamantes no gorgulho seja superior à concentração da rocha original, uma vez que ocorre redução de volume, além disto, o fato do material encontrar-se desagregado facilita o processo de lavra.

Além da relação espacial existente entre os filitos hematíticos e as crostas lateríticas, a ausência de outras rochas ricas em minerais ferro-magnesianos descarta outro material parental como fonte de ferro para a formação do gorgulho. Com tudo que foi apresentado, a ocorrência notória de garimpos relacionados ao gorgulho é um forte argumento para vincular o filito hematítico como fonte primária dos diamantes na região estudada. 


\subsection{5 - Depósitos Aluvionares}

Depósitos aluvionares não consistem no foco deste trabalho, contudo representam importante ambiente de lavra na área estudada. Mensurar a quantidade de diamantes extraídos da Serra do Espinhaço Meridional é uma tarefa complexa, verdadeiro é que consiste em um valor muito grande, visto todos os relatos históricos e o fato de diamantes serem recuperados desde o século XVII até os dias atuais. Quase todas as drenagens que cortam unidades da Formação Sopa Brumadinho de alguma forma já foram alvo de atividade garimpeira, seja por lavra mecanizada ou manual, de forma que quantidade significativa de gemas foi extraída sem registro.

De acordo com Chaves \& Uhlein (1991) o Rio Jequitinhonha possui maior importância na ocorrência de diamantes a partir da cidade de Medanha, pois até tal localidade seu gradiente é elevado, fator que não possibilita a formação de depósitos aluvionares significativos. A partir de Medanha ocorre uma redução abrupta do gradiente de relevo, o que reduz a energia hidrodinâmica e favorece deposição dos minerais pesados. Tal redução de energia e presença de traps proporcionam as condições ideais para a formação de depósitos aluvionares de diamantes. De Medanha em direção à jusante desenvolveram-se grandes lavras de dragagem, a Mineração Rio Novo e a Mineração Tejucana se destacaram pela quantidade de diamantes retirados dos depósitos aluvionares. Os autores informam que a Tejucana lavrava mensalmente $1.000 .000 \mathrm{~m}^{3}$ de aluvião, com produção da ordem de 5.000 quilates.

\section{2 - Campos Diamantíferos Objetos do Presente Estudo}

Devido a questões ambientais, a atividade garimpeira encontrar-se em declínio, de modo que atualmente apenas alguns "faiscadores" trabalham de forma isolada e, sobretudo, na época chuvosa. Sendo assim, durante realização da etapa de campo procurou-se sempre que possível contatar garimpeiros que participaram efetivamente do processo de lavra para assim obter maiores informações, tais como os locais em que afloram o "giz” (filito hematítico) e qual sua relação com os diamantes. Verificou-se que uma parcela dos garimpeiros especializou-se em recuperar diamante de determinado material, seja ele a "massa” (metaconglomerado-metabrecha), fontes aluvionares, gorgulho ou o próprio filito hematítico. Tal fato não é de se estranhar, uma vez que é possível observar inúmeros locais de lavra a partir de diferentes tipos de rochas. O foco principal da etapa campo consistiu na determinação das unidades diamantíferas presentes em áreas consagradas de garimpo e verificação da presença e relação existente com o filito hematítico, rocha que aflora sistematicamente na porção oeste das lavras. 
Deste modo, foram priorizadas as lavras que houve atividade garimpeira diretamente de rocha, ou seja, excluindo as ocorrências em ambientes aluvionares. Uma quantidade considerável de garimpos é evidenciada em imagens de satélite, formando rasgões que compõem verdadeiras cicatrizes no relevo. O Distrito Diamantífero de Diamantina está localizado na Província Diamantífera Espinhaço, este distrito é composto por diversos campos diamantíferos, neste trabalho os campos Extração, Sopa-Guinda e São João da Chapada foram visitados devido à importância histórica e abundância de áreas de lavra garimpeira, sendo as principais lavras ilustradas na Figura 3.28.

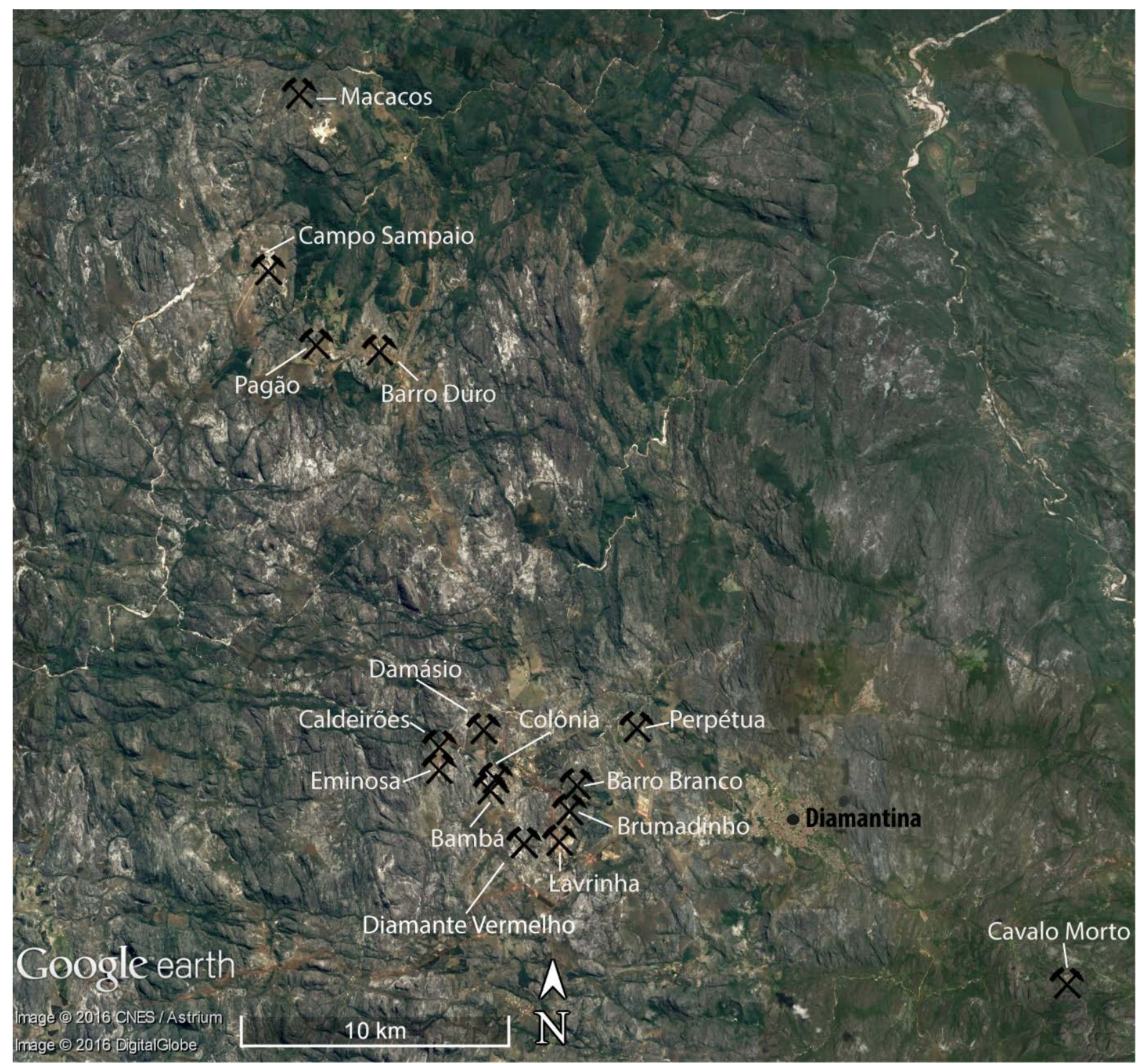

Figura 3.28- Imagem ilustrando as principais lavras visitadas neste trabalho (Fonte: Google Earth). 


\subsection{1- Campo Diamantífero de Extração}

O campo diamantífero de Extração está localizado a sudeste de Diamantina, em domínios pertencentes, em sua maior parte, à Formação Sopa Brumadinho. As drenagens presentes na região desaguam à leste no Rio Jequitinhonha, importante local de lavra em ambiente aluvionar. O campo de Extração caracteriza-se pelas maiores espessuras das fácies metaconglomeráticas do distrito diamantino. As lavras mais conhecidas são Cavalo Morto, Boa Vista, Cafundó e Serrinha. Segundo dados de Haraly \& Svisero (1986), os maiores diamantes da província diamantífera Espinhaço são provenientes do campo de Extração, o maior com cerca de 64,4 quilates recuperado em 1954 no Ribeirão do Inferno, que é abastecido por águas provenientes da Lavra Serrinha, outros diamantes com 56, 50, 34, 30 e 26 quilates foram recuperados na Lavra da Boa Vista.

O fato do campo de Extração possuir os maiores diamantes já recuperados questiona as hipóteses existentes sobre o caráter distal dos diamantes, uma vez que ao assumir que a fonte encontra-se à oeste sobre Cráton do São Francisco, o coerente seria ocorrer redução de tamanho dos diamantes para leste, o que não é verificado. A lavra Cavalo Morto foi visitada neste trabalho.

\section{Lavra Cavalo Morto}

A lavra Cavalo Morto foi visitada devido à sua contribuição histórica, porém como não há atividade recente nem moradias nas adjacências da lavra, a vegetação dificultou o acesso e reconhecimento das unidades, entretanto pacotes espessos de metaconglomerados e afloramentos de filito hematítico foram identificados, o filito hematítico possui cor cinza e pseudomorfos estirados (Figuras 3.29 e 3.30). Demais pontos observados por imagem de satélite foram visitados, contudo consistiam em áreas de depósitos aluvionares.

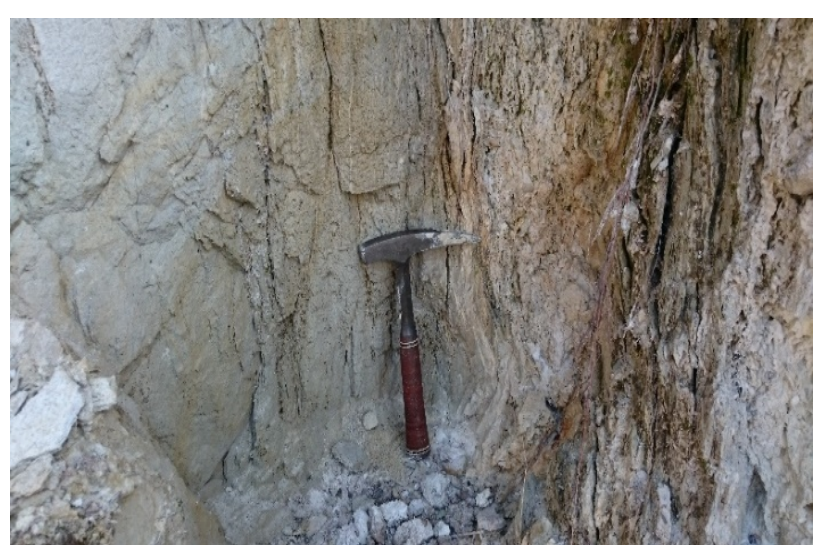

Figura 3.29 - Afloramento de filito hematítico na lavra Cavalo Morto.

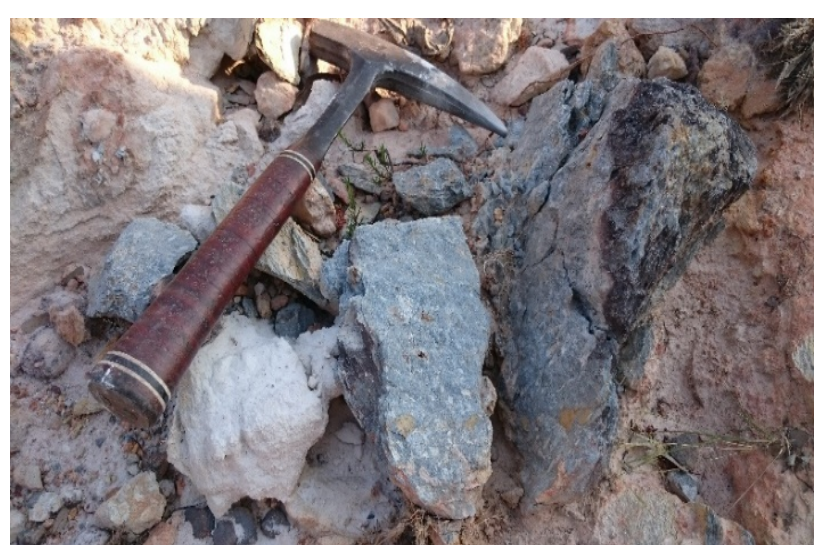

Figura 3.30 - Blocos de filito hematítico situados nas adjacências da lavra, rocha cinza com pseudomorfos sericitizados. 


\subsection{2- Campo Diamantífero Sopa-Guinda}

O campo diamantífero Sopa-Guinda consiste na principal área de estudo deste trabalho, visto que há considerável concentração de lavras. Localizada à oeste da cidade de Diamantina, as unidades presentes são as formações São João da Chapada, Sopa Brumadinho e Galho do Miguel.

A unidade predominante consiste na Formação Sopa Brumadinho, composta por quartzitos associados com metaconglomerados polimíticos, estes com clastos predominantemente de quartzitos, conglomerados e filitos hematíticos. Como demais litologias presentes destacam-se filitos hematíticos, filitos sericíticos, metabrechas quartzíticas e metassiltitos. Foram visitadas as lavras Perpétua, Barro Branco, Lavrinha, Brumadinho, Diamante Vermelho, Colônia, Bambá, Caldeirões, Eminosa e Damásio.

\section{Lavra Perpétua}

Localizada à noroeste do aeroporto de Diamantina, o local encontra-se atualmente inativo. Amontoados de material lavrado ocorrem dispersos, porém não foi identificada a ocorrência de depósitos metaconglomeráticos no local.

De acordo com a natureza do material lavrado, o mesmo consistia em sua maioria aluvionar, justificável pela presença de uma pequena drenagem à sul, porém a ocorrência notória de escavações sugere existência de rochas diamantíferas. Fragmentos de quartzo de veios são abundantes nos amontoados, sugerindo que tais veios ocorram associados com as unidades lavradas.

Afloramentos de filito hematítico ocorrem de forma isolada, (Figura 3.31) assim como filito sericítico (Figura 3.32). O filito hematítico (Figura 3.33) possui coloração cinza com eventuais concentrações de óxidos e afloram na forma de cristas verticalizadas orientadas N-S. Pontualmente torna-se difícil a caracterização da origem do filito, entretanto as feições presentes na rocha tendem à origem ígnea, ou seja, filito hematítico (Figura 3.34).

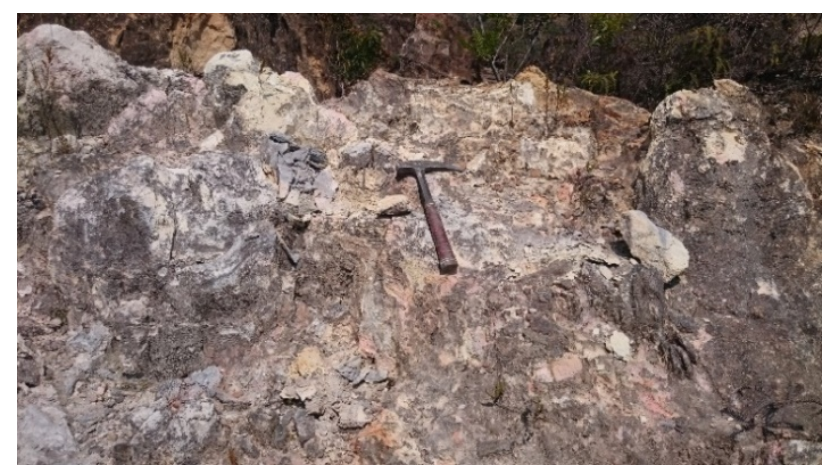

Figura 3.31 - Afloramento de cristas verticalizadas de filito hematítico na lavra Perpétua.

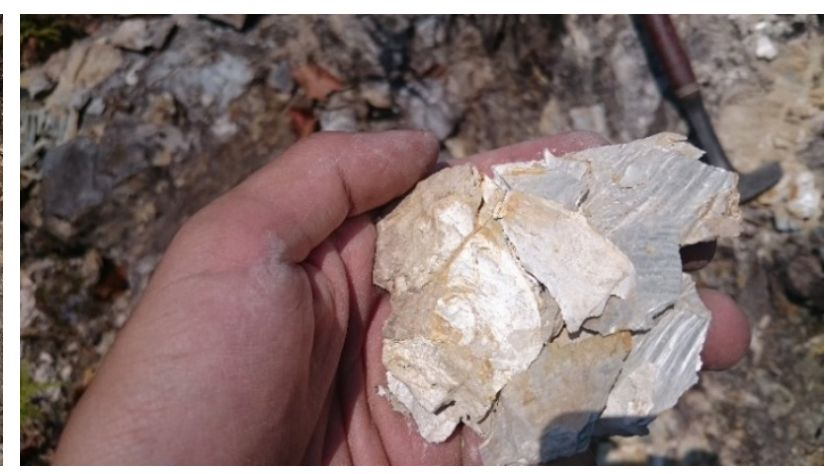

Figura 3.32 - Filito sericítico aflorante na lavra Perpétua, visivelmente distinto do filito hematítico. 


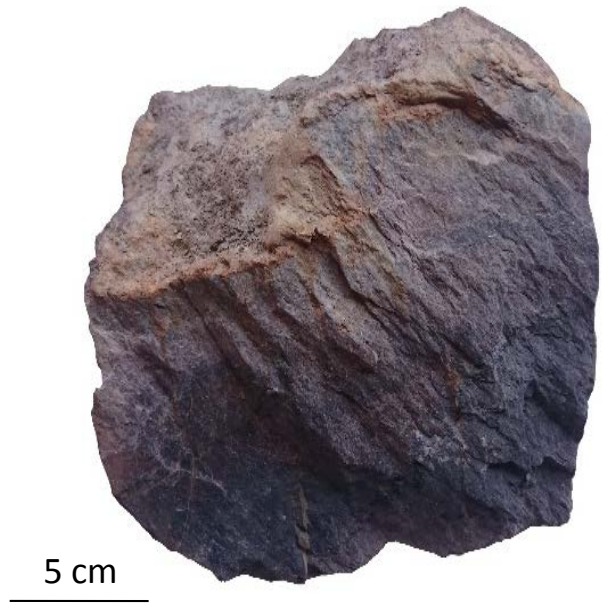

Figura 3.33 - Amostra de filito hematítico da lavra Perpétua, rocha de cor cinza com eventuais concentrações de óxidos.

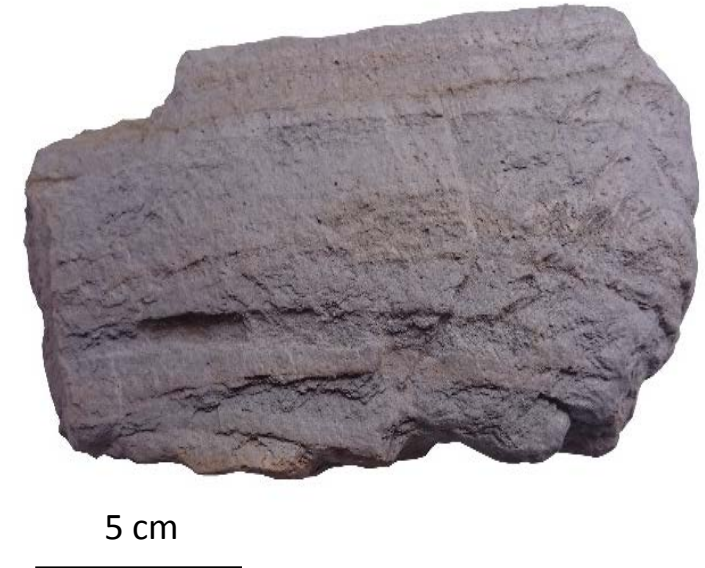

Figura 3.34 - Amostra de filito de com feições que se assemelham ao filito sericítico.

\section{Lavra Barro Branco}

A lavra Barro Branco localiza-se a sudoeste da lavra Perpétua (Figura 3.35). No interior da lavra ocorrem níveis de metaconglomerado friável (Figura 3.36), com indícios de atividade garimpeira recente. Afloram camadas espessas de quartzito e subordinadamente filito sericítico, à oeste o filito hematítico na forma de cristas verticalizadas.

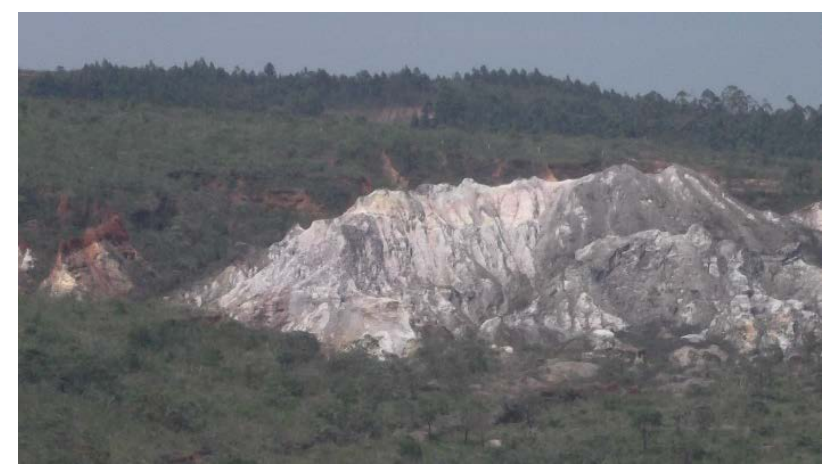

Figura 3.35 - Vista geral da lavra Barro Branco.

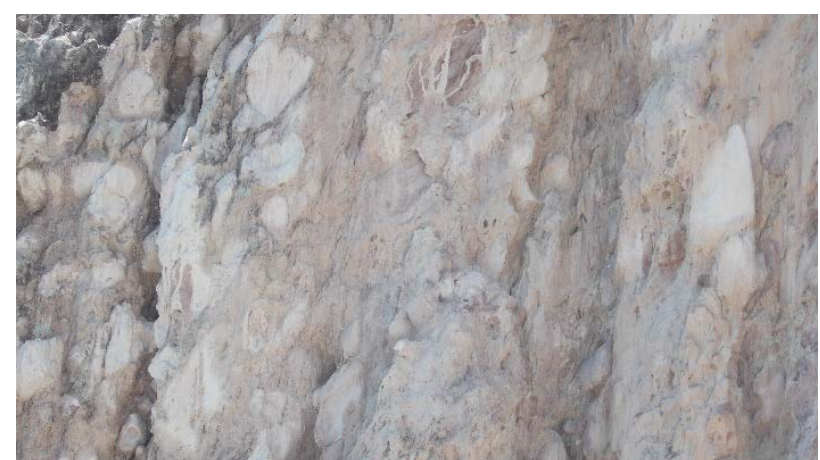

Figura 3.36 - Metaconglomerado friável, local de lavra recente na lavra Barro Branco.

O filito hematítico da lavra Barro Branco possui coloração cinza com textura brechoidal (Figura 3.37), os pseudomorfos menores são visivelmente tabulares, enquanto que os maiores são arredondadas, indicando heterogeneidade da rocha original. Localmente, o filito hematítico encontra-se em maior grau de alteração intempérica, exibindo coloração avermelhada (Figura 3.38), contudo não há evidências de crostas lateríticas. 


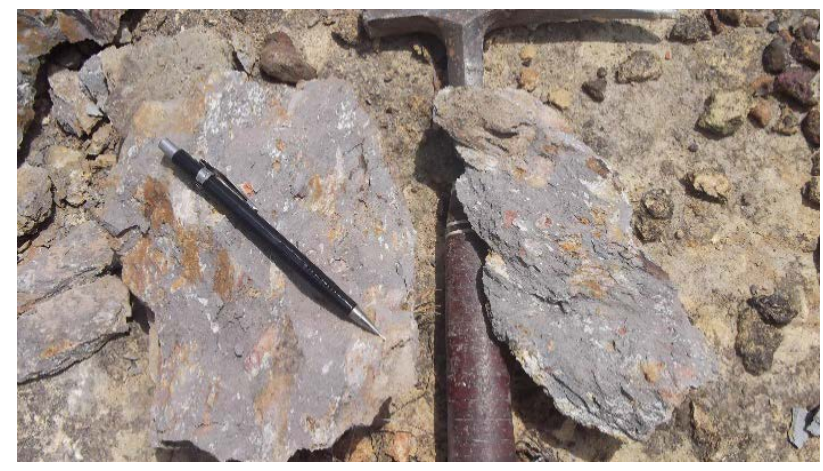

Figura 3.37 - Filito hematítico com textura brechoidal exibindo pseudomorfos tabulares.

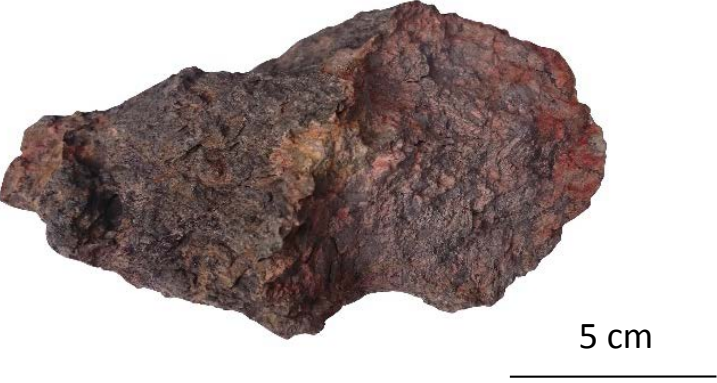

Figura 3.38 - Amostra de filito hematítico de coloração avermelhada devido à alteração intempérica.

\section{Lavra Lavrinha}

A lavra Lavrinha está localizada a cerca de $10 \mathrm{~km}$ à oeste de Diamantina, adjacente ao povoado Guinda. Considerada uma das principais lavras da região, contêm excelentes afloramentos de metaconglomerados, em sua maioria porções litificados que não possibilitaram a lavra por desmonte hidráulico. Na porção oeste da lavra e adjacente aos metaconglomerados afloram níveis de filito hematítico, a rocha possui alteração abrupta de textura, variando desde homogênea de cor cinza à preta com textura brechoidal (Figuras 3.39 e 3.40).
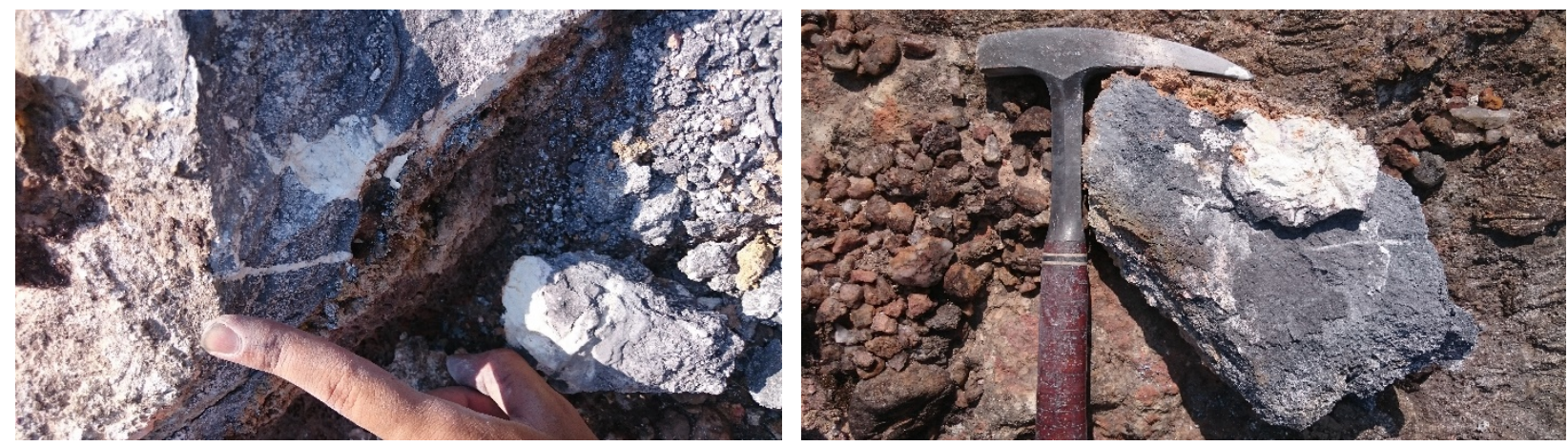

Figuras 3.39 e 3.40 - Filito hematítico exposto na região da lavra Lavrinha, rocha escura com porções sericitizadas apresentando textura brechoidal.

O filito hematítico aflora abaixo de espessas camadas de metaconglomerados e quartzitos, desta forma presume-se que tais unidades depositaram, em parte, sobre o filito hematítico. Localmente há material laterítico proveniente da alteração do metaconglomerado, tal material encontra-se disposto em amontoados de material lavrado, o filito hematítico adjacente também se encontra em maior grau de alteração intempérica (Figura 3.41), contudo, não formou crostas lateríticas. Níveis de filito sericítico ocorrem intercalados com os filitos hematíticos (Figura 3.42). 


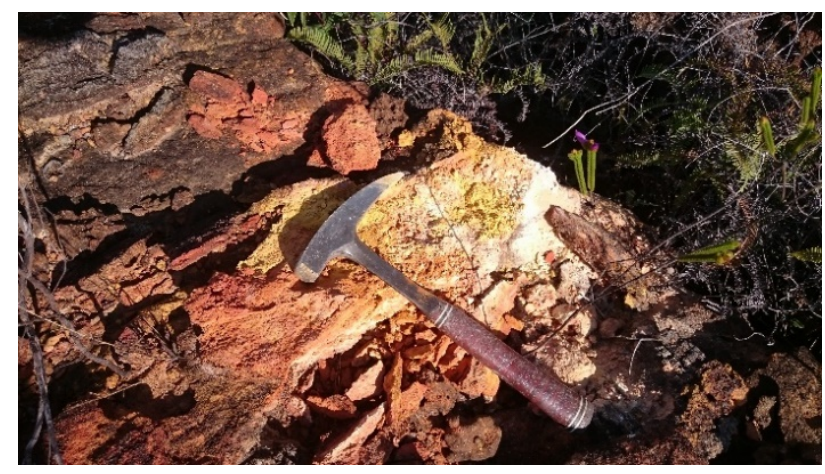

Figura 3.41 - Filito hematítico em elevado grau de alteração intempérica, lavra Lavrinha.

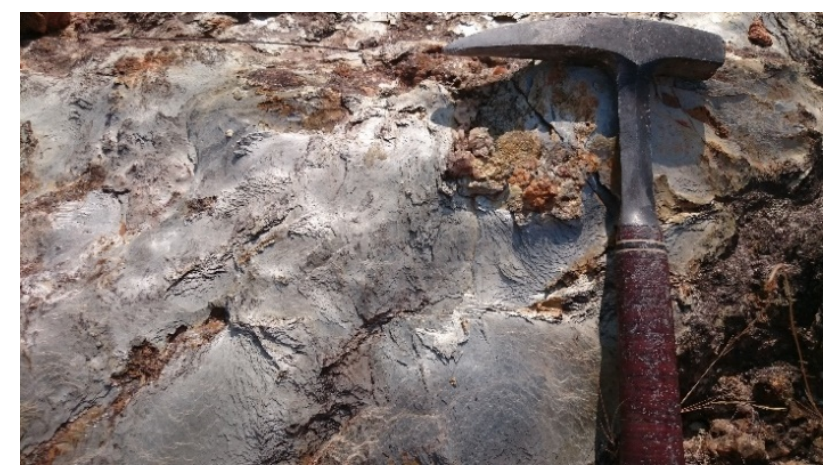

Figura 3.42 - Ocorrência de filito sericítico, rocha com brilho e crenulações características.

\section{Lavra Brumadinho}

A lavra Brumadinho (Figura 3.43) está localizada logo à nordeste da lavra Lavrinha. Não ocorrem quantidades consideráveis de metaconglomerados, estes estão presentes, sobretudo, na forma de blocos. O filito hematítico aflora de maneira recorrente em toda a lavra, disposto como cristas verticalizadas orientadas N-S e exibindo nítida relação de discordância com rochas quartzíticas (Figura 3.44).

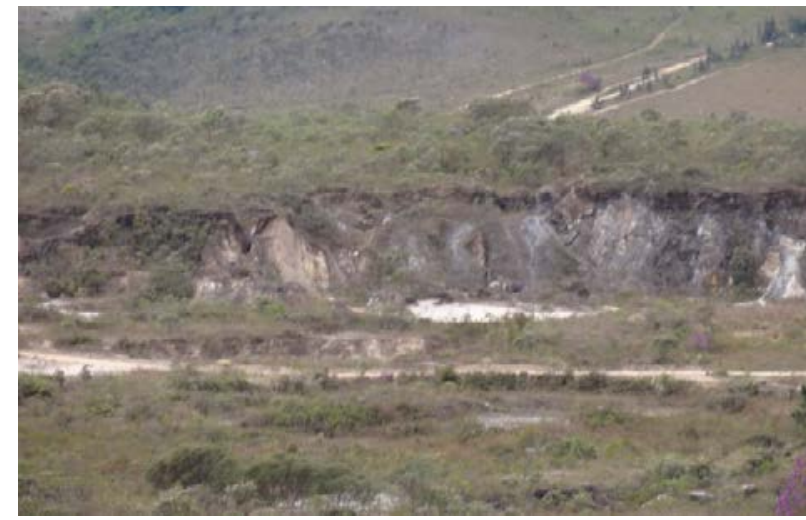

Figura 3.43 - Vista geral da lavra Brumadinho.

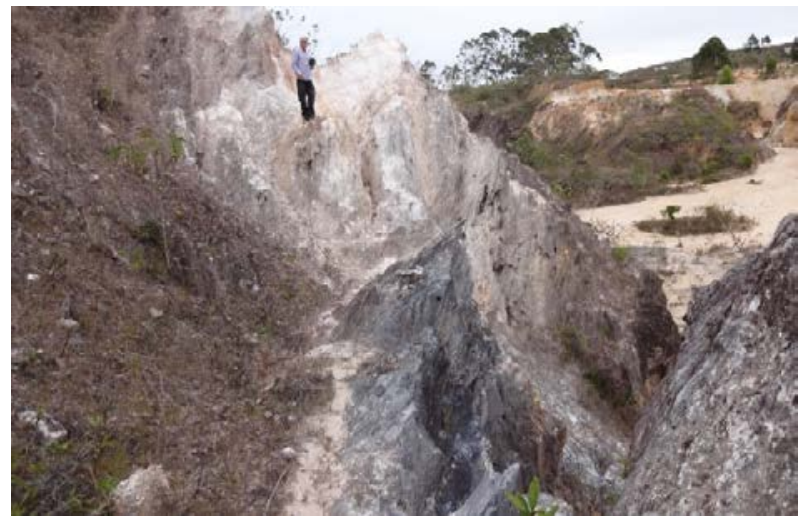

Figura 3.44 - Filito hematítico aflorando como cristas verticalizadas na lavra Brumadinho.

Na região superior da lavra Brumadinho é possível identificar área recente de atividade garimpeira sobre o filito hematítico, evidenciada pela depressão gerada e concentrados de peneira compostos por fragmentos do filito (Figura 3.45). Os filitos hematíticos são em sua maioria pouco intemperizados, ocorrem com coloração acinzentada, nódulos de óxidos e subordinadamente turmalina, localmente ocorre alternância de níveis ricos em óxidos com níveis sericíticos (Figura 3.46 e 3.47). Em um canal à sul da lavra o filito hematítico ocorre com coloração arroxeada (Figura 3.48). 


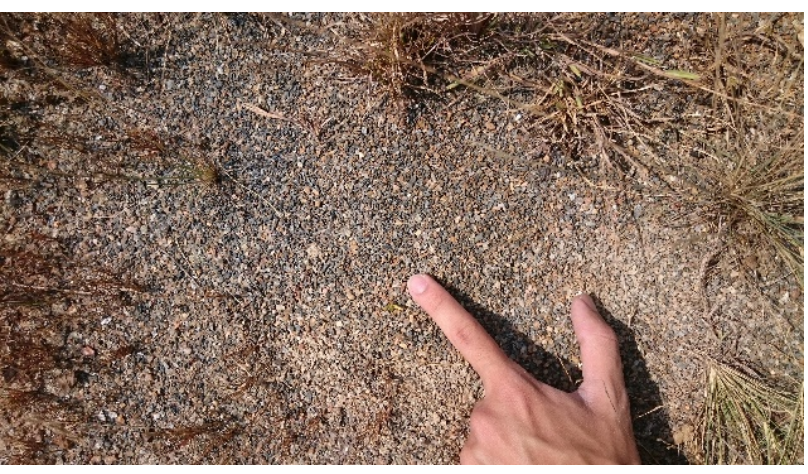

Figura 3.45 - Concentrado de garimpo sobre o filito hematítico, localizado na lavra Brumadinho.

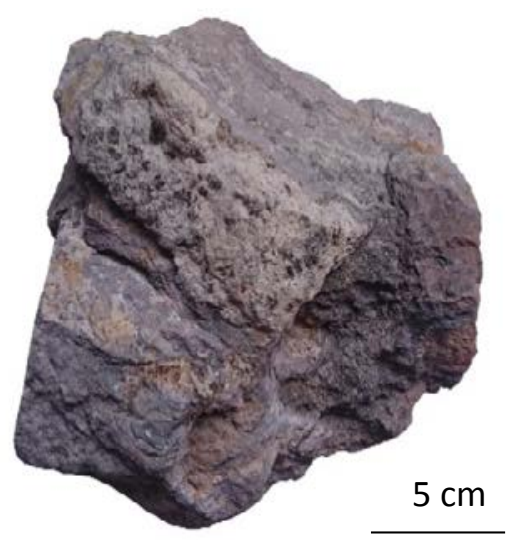

Figura 3.47 - Amostra de filito hematítico ocorrente da lavra Brumadinho.

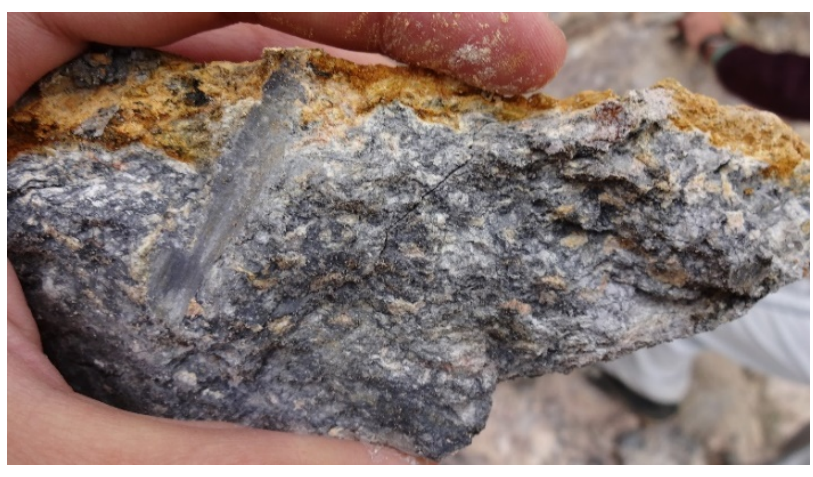

Figura 3.46 - Detalhe do filito hematítico destacando seu aspecto heterogêneo.

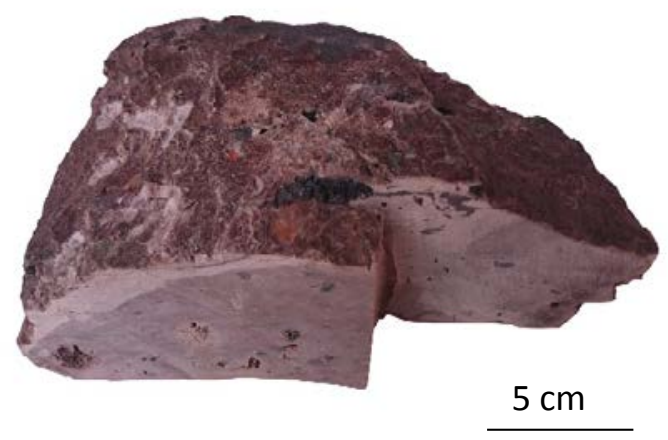

Figura 3.48 - Amostra de filito hematítico de coloração arroxeada, localizado em canal ao sul da lavra Brumadinho.

\section{Lavra Diamante Vermelho}

A lavra Diamante Vermelho está localizada à leste da Lavrinha. Nas proximidades da lavra afloram muscovita xistos, no seu interior lentes de metaconglomerados orientadas segundo direção N-S afloram em toda sua extensão. Filitos hematíticos afloram à oeste, constituem rochas de cor cinza e homogêneas, uma vez que não ocorrem concentrações significativas de óxidos ou porções sericitizadas (Figura 3.49).

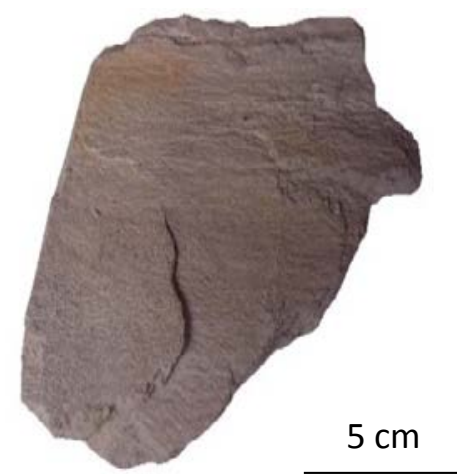

Figura 3.49 - Amostra do filito hematítico presente na lavra Diamante Vermelho. 


\section{Lavra Colônia}

A lavra Colônia encontra-se logo à oeste do Povoado Sopa. Camadas espessas de metaconglomerados ocorrem intercaladas com lentes de filito hematítico verticalizadas e orientadas segundo direção N-S. Tais lentes encontram-se dispostas de forma intermitente e por vezes deslocadas, como ilustrado na Figura 3.50. Na porção norte da lavra, a metabrecha quartzítica aflora de forma litificada, representada por matriz constituída por filito hematítico associado com fragmentos arredondados de quartzito. O filito hematítico ocorre preferencialmente na porção oeste da lavra, intercalado com pacotes de quartzitos e metaconglomerados (Figura 3.51).

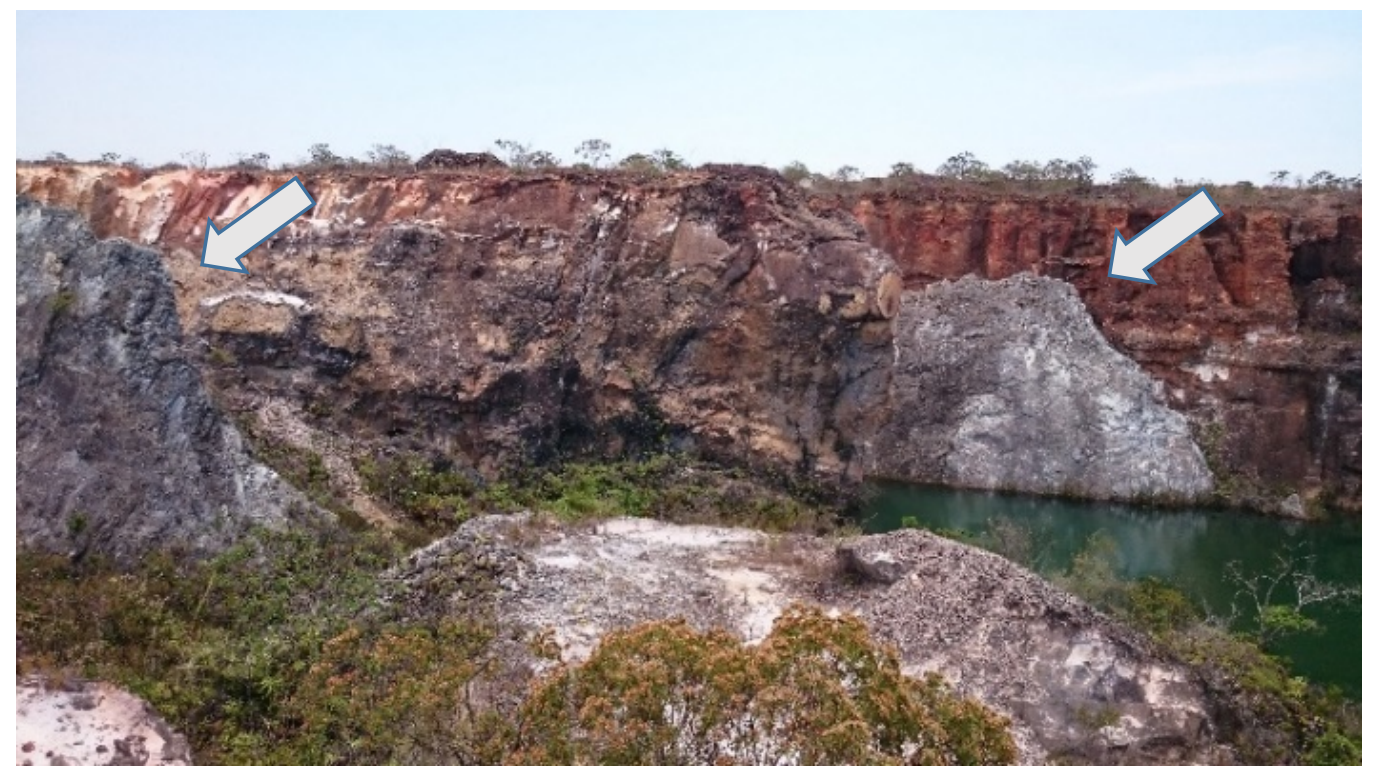

Figura 3.50 - Afloramentos do filito hematítico ocorrendo na forma de cristas verticalizadas

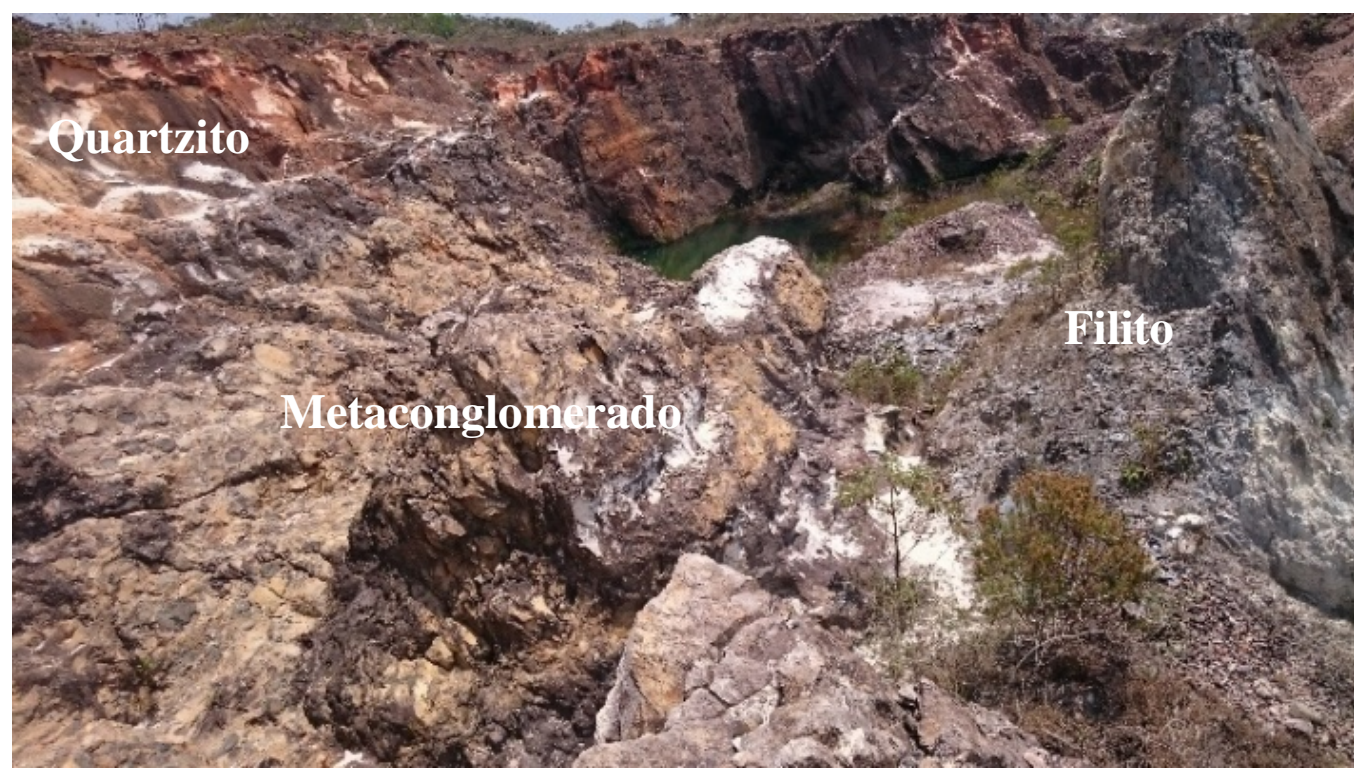

Figura 3.51 - Intercalação de quartzito, metaconglomerado e filito na lavra Colônia.

Atividade garimpeira ocorre de forma esporádica, utilizando água de chuva acumulada em depressões dispostas no interior da lavra. Fragmentos de filito hematítico são abundantes, tanto no 
rejeito de lavra (Figura 3.52), quanto nos metaconglomerados, que por sua vez são visivelmente mais angulosos do que os demais clastos (Figura 3.53). O filito hematítico apresenta textura típica, de cor cinza com nódulos de óxidos e presença de turmalina (Figura 3.54 e 3.55). Níveis de filito sericítico afloram localmente.

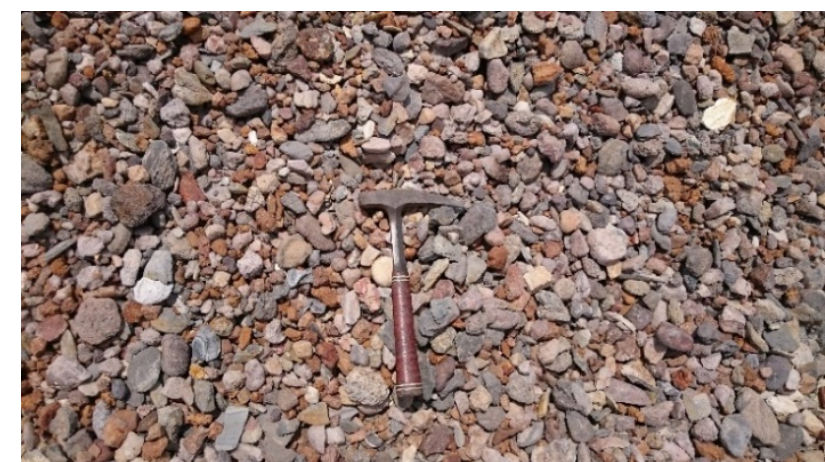

Figura 3.52 - Abundância de filitos no rejeito da atividade garimpeira nas adjacências da lavra Colônia.

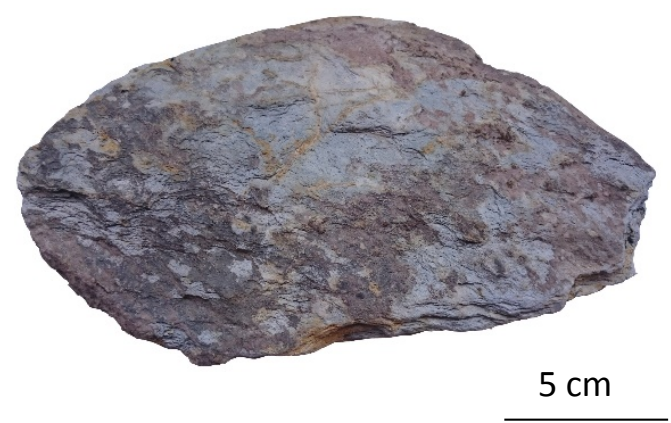

Figura 3.54 - Amostra do filito hematítico presente na lavra Colônia.

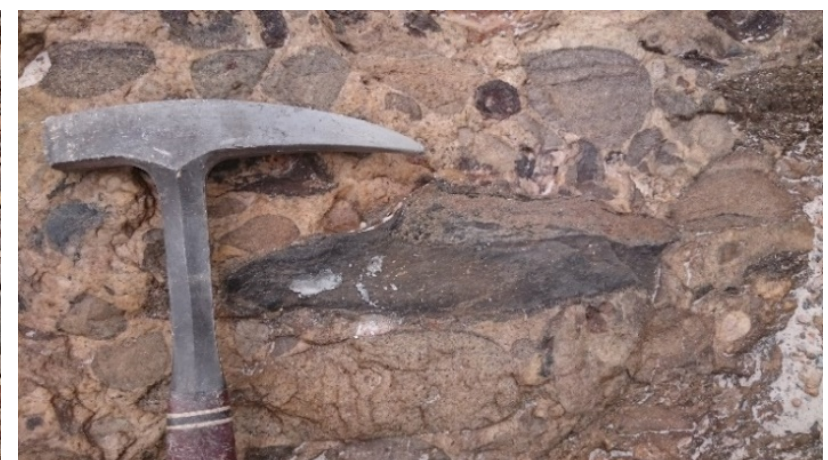

Figura 3.53 - Fragmento anguloso de filito hematítico no metaconglomerado.

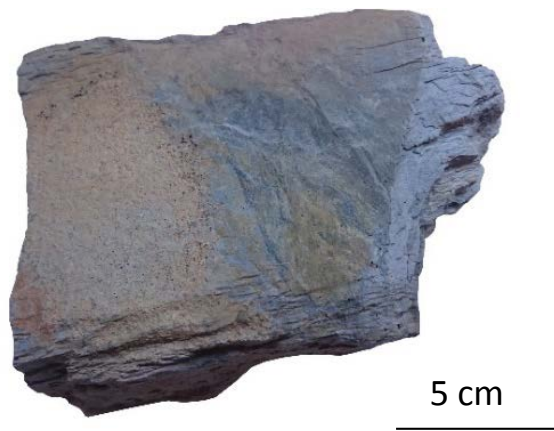

Figura 3.55 - Amostra de filito sericítico, aflorante na lavra Colônia.

\section{Lavra Bambá}

A lavra Bambá está situada à oeste da lavra Colônia, disposta de maneira que as duas lavras interligam-se a sul. Quartzitos ocorrem de forma abundante, sendo inclusive local de retirada de material arenoso, o que expandiu as dimensões da antiga área de garimpo (Figura 3.56). Níveis de metaconglomerados afloram acima de quartzitos, contudo de forma isolada. Camadas de metapelitos ocorrem continuamente acima de quartzitos. Ao sul da lavra verificam-se indícios de atividade garimpeira a partir do filito hematítico, este que aflora com coloração rosada devido ao elevado grau de alteração (Figura 3.57). 


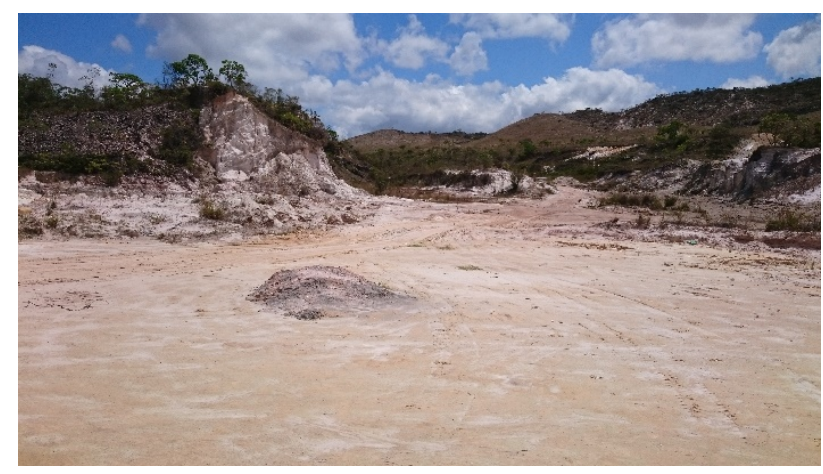

Figura 3.56 - Vista geral da lavra Bambá, local com abundante material arenoso.

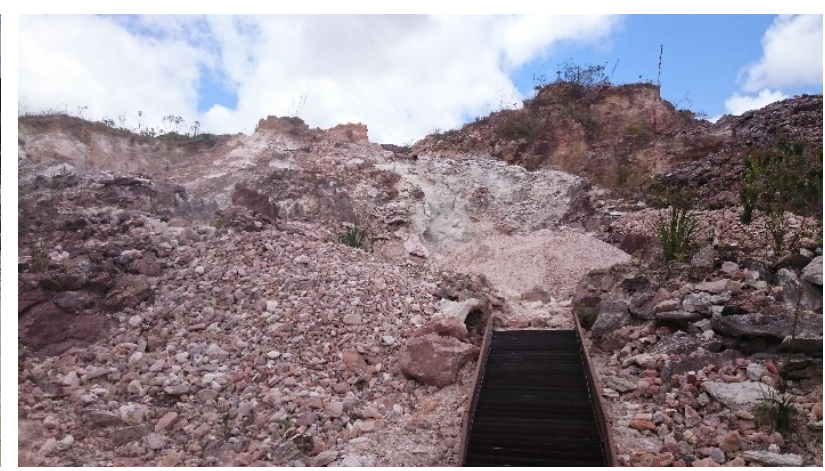

Figura 3.57 - Área de garimpo a partir do filito hematítico alterado.

\section{Lavra Caldeirões}

A lavra Caldeirões (Figura 3.58) está localizada à norte da lavra Colônia. A área foi garimpada manualmente durante décadas por uma família local. É notória a abundância de filito hematítico, este que ocorre em nítida associação com a metabrecha quartzítica. A área elevada à leste da depressão é constituída exclusivamente pelo filito hematítico, local em que ocorre ampla variação textural da rocha. Em determinados locais houve retirada de material diretamente do filito hematítico, formando depressões retangulares.

No interior da lavra, fragmentos de filito hematítico ocorrem em abundância apresentando grande diversidade de texturas (Figuras 3.59 a 3.61). As paredes da depressão são constituídas por filito hematítico em elevado grau de alteração intercalado com níveis de metabrecha quartzítica.

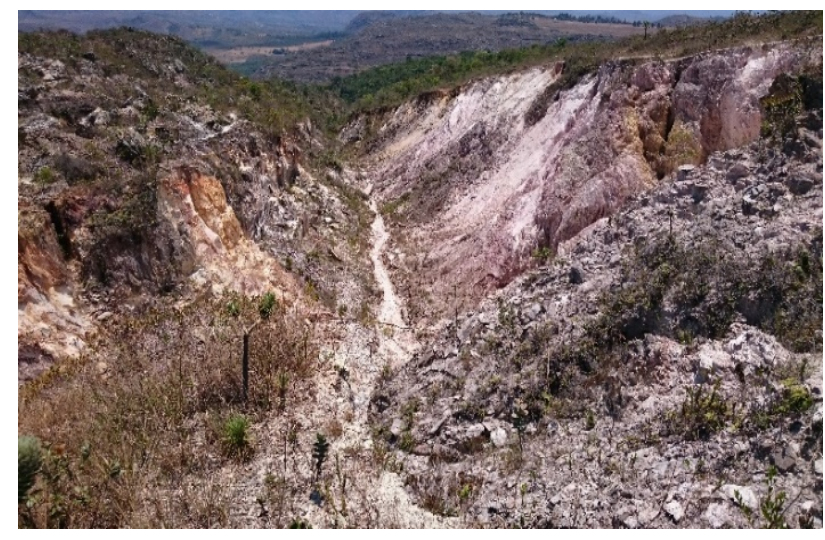

Figura 3.58 - Vista geral da lavra Caldeirões.

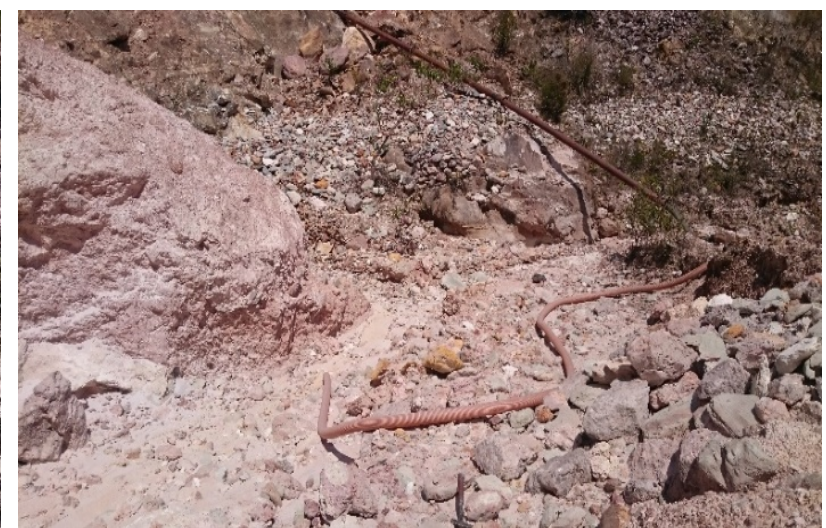

Figura 3.59 - Interior da lavra Caldeirões com destaque para ocorrência de filito hematítico e material utilizado no desmonte hidráulico. 


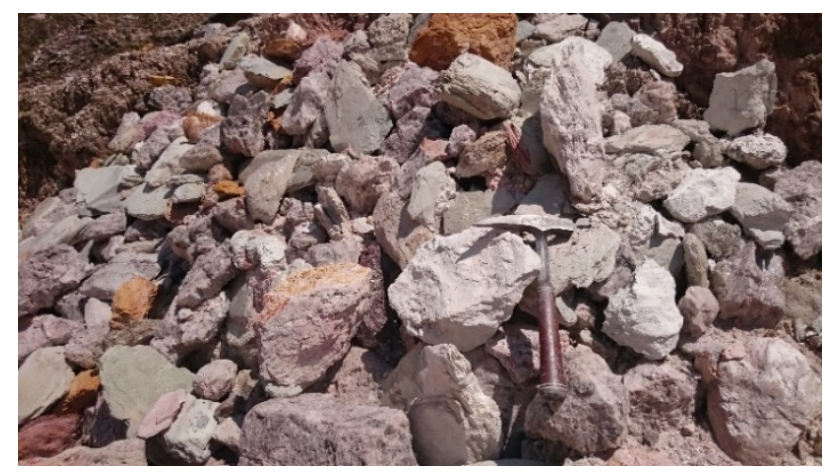

Figura 3.60 - Variedades de texturas de filito hematítico presentes no interior da lavra Caldeirões.

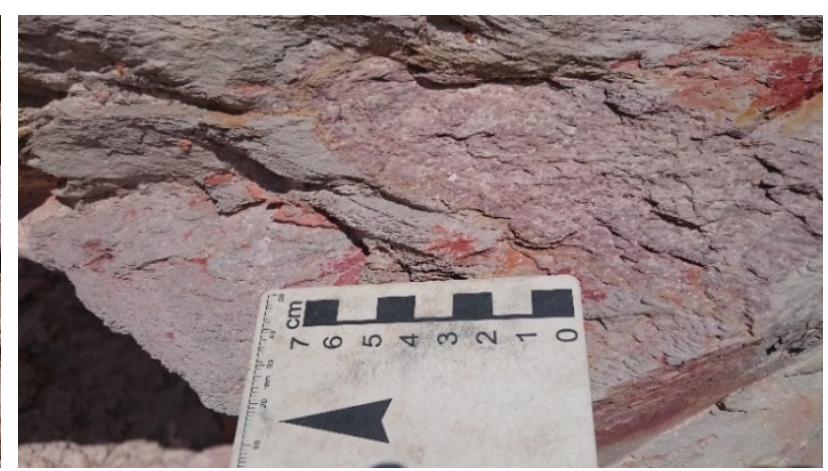

Figura 3.61 - Detalhe de bloco de filito hematítico em estágio inicial de alteração, adquirindo a tonalidade rosada.

A metabrecha quartzítica apresenta similaridade textural com o filito hematítico, o que dificulta seu reconhecimento imediato. O garimpo é realizado através do desmonte hidráulico das paredes da depressão, o material é então conduzido à bica sluice que concentra os minerais pesados e libera o material pelítico. De acordo com garimpeiros locais, do volume de material lavrado uma porção diminuta de minerais pesados é recuperada, de modo que é necessário tratar grande volume para recuperar diamantes. Amostras de diamantes recuperados desta associação de metabrecha/filito hematítico (sem valor comercial devido ao tamanho reduzido, porém importantes para estudos morfológicos) foram cedidas e posteriormente serão discutidas as feições morfológicas destes diamantes. Atravessando a depressão, no lado superior oeste, afloram metaconglomerados contendo fragmentos angulosos de filito hematítico (Figura 3.62) e em contato direto com os metaconglomerados (Figura 3.63). Dentre as texturas observadas na lavra destacam-se: filito cinza incrustado de magnetita (Figura 3.64); filito verde rico em clorita (Figura 3.65); filito cinza com ocorrências de pequenos nódulos arredondados de óxidos e filito rosa em elevado grau de alteração.

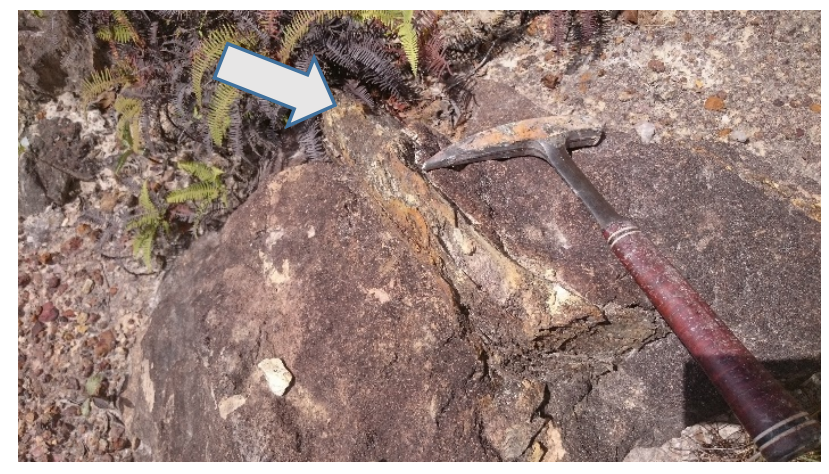

Figura 3.62 - Fragmento anguloso de filito hematítico em metaconglomerado localizado na lavra Caldeirões.

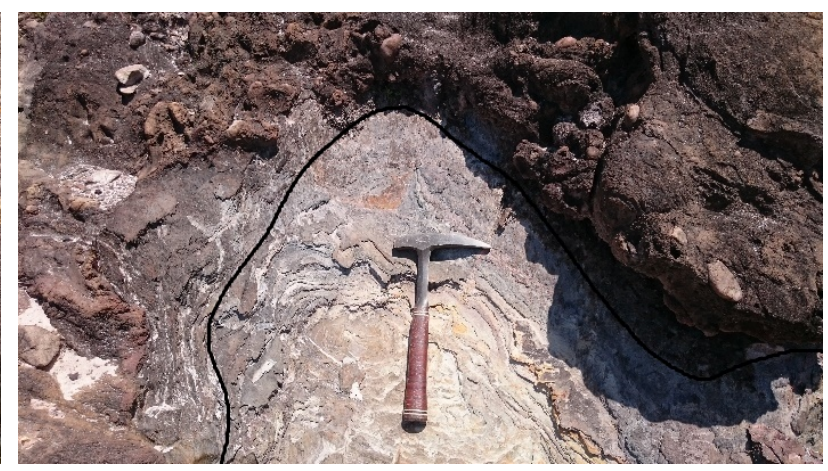

Figura 3.63 - Contato do metaconglomerado com filito hematítico. 


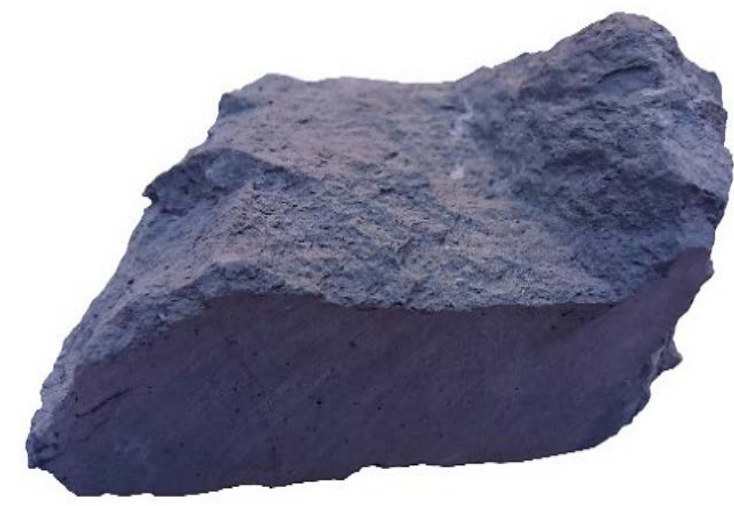

$5 \mathrm{~cm}$

Figura 3.64 - Filito hematítico rico em magnetita euhédrica, ocorrente na lavra Caldeirões.

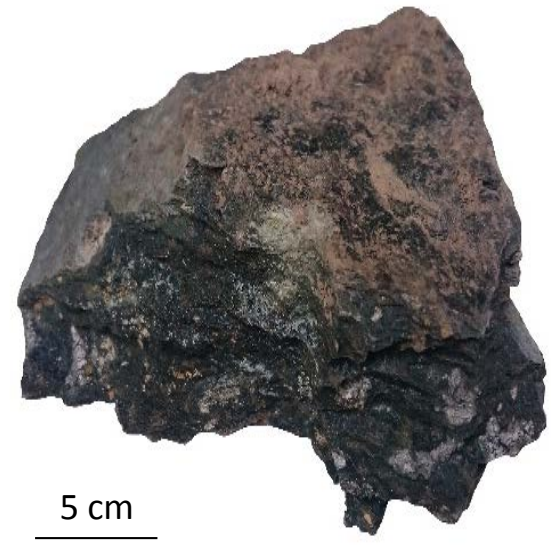

Figura 3.65 - Filito hematítico esverdeado devido à ocorrência de clorita. Ocorrem também pseudomorfos brancos, lavra Caldeirões.

\section{Lavra Eminosa}

A lavra Eminosa corresponde ao antigo local de atividade da empresa homônima. O filito hematítico aflora em todo o percurso deste a lavra Caldeirões até a lavra Eminosa (aproximadamente $1 \mathrm{~km}$ ). A região entre as lavras possui relevo plano, o que possibilitou a formação de espessas camadas de gorgulho sobre o filito hematítico de modo que, assim como na Lavra Caldeirões, observa-se a retirada de filito hematítico em depressões retangulares.

A lavra Eminosa possui maior dimensão do que a Caldeirões, e no interior da área lavrada localmente afloram metaconglomerados e metabrechas quartzíticas, contudo a litologia predominante consiste no filito hematítico, que por sua vez aflora em toda porção oeste. O filito hematítico apresenta-se em sua maioria friável de coloração rosada, o que facilita a lavra e explica a atividade sobre a rocha (Figuras 3.66 e 3.67).

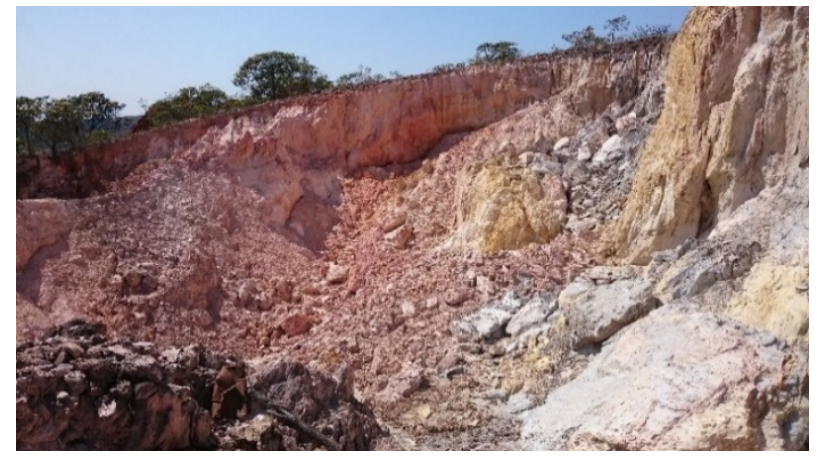

Figuras 3.66 - Vista geral da lavra Eminosa, paredes Figura 3.67 - Fragmentos de filito hematítico das lavras são compostas por filito hematítico.

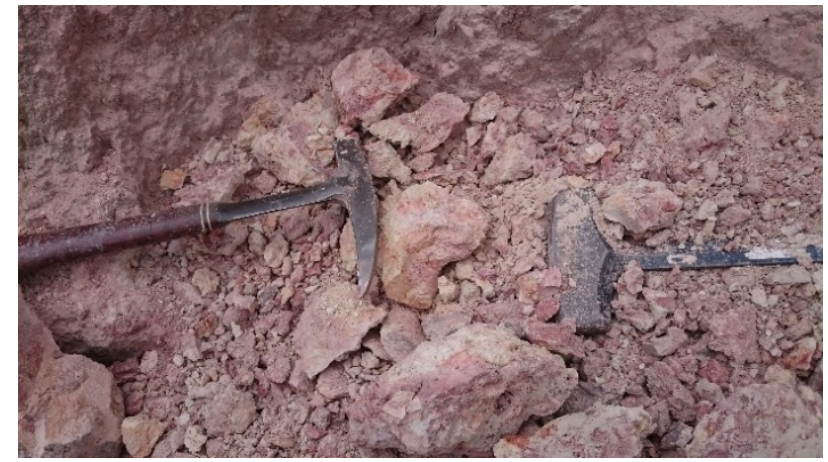

friável.

Localmente e adjacente ao filito alterado (Figura 3.68), o filito hematítico aflora com textura idêntica ao filito da lavra Caldeirões (Figura 3.69), por vezes exibindo concentrações 
arredondadas de óxidos. Na porção sul da lavra, próximo à barragem, afloram níveis de filito sericítico.

\section{Lavra Damásio}

A lavra Damásio está localizada próxima ao povoado de Sopa, à oeste da estrada que conecta ao povoado São João da Chapada. A lavra preserva grande volume de metaconglomerado litificado, formando grandes paredões. O filito hematítico aflora à oeste na forma de lentes verticalizadas (Figuras 3.70 e 3.71).

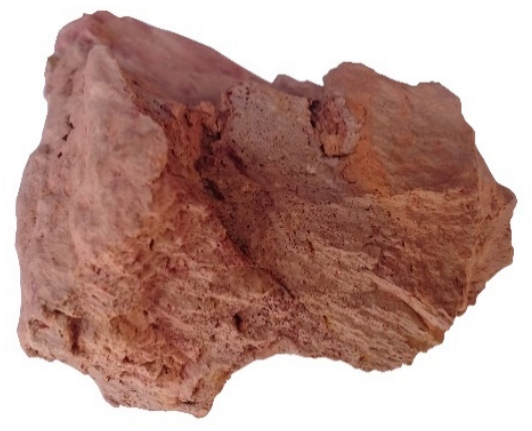

$5 \mathrm{~cm}$

Figura 3.68 - Amostra do filito hematítico alterado.

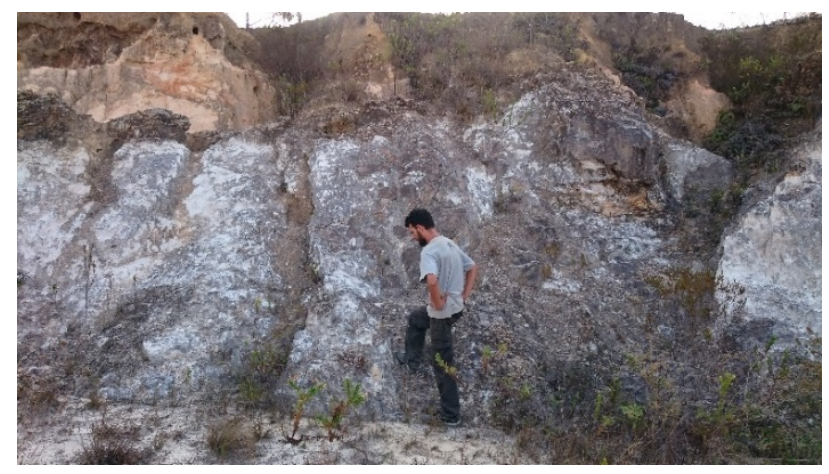

Figura 3.70 - Afloramento de filito hematítico na lavra Damásio.

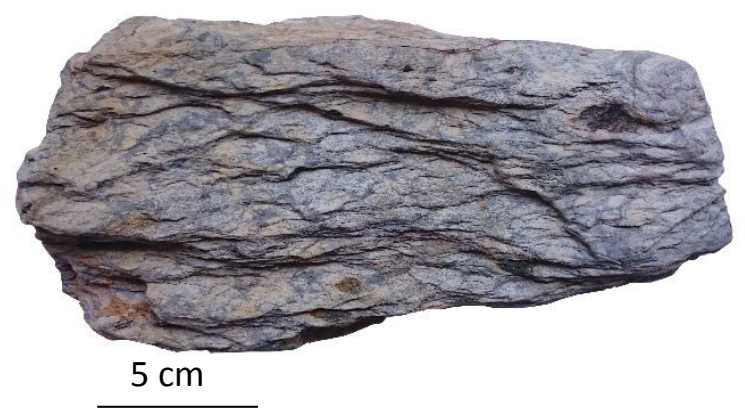

Figura 3.69 - Amostra de filito hematítico menos alterado.

O filito hematítico também ocorre na forma de injeções métricas em quartzitos (Figura 3.72), ilustrando seu carácter discordante. A rocha possui coloração cinza, por vezes com pseudomorfos rosados (Figura 3.73). Fragmentos angulosos de filito hematítico são recorrentes nos metaconglomerados aflorantes à leste, indicando proximidade da área fonte e contribuição dos filitos hematíticos durante a sedimentação dos conglomerados (Figura 3.74). 


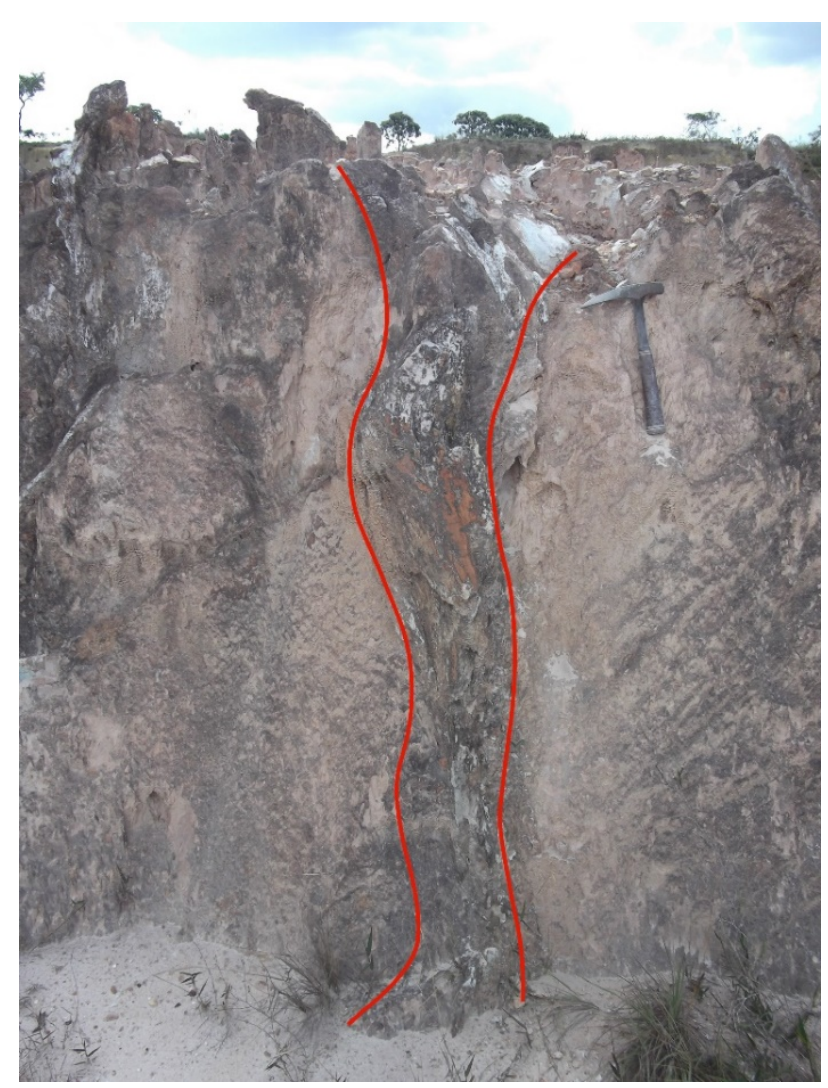

Figura 3.72 - Dique de filito hematítico cortando quartzitos na lavra Damásio.

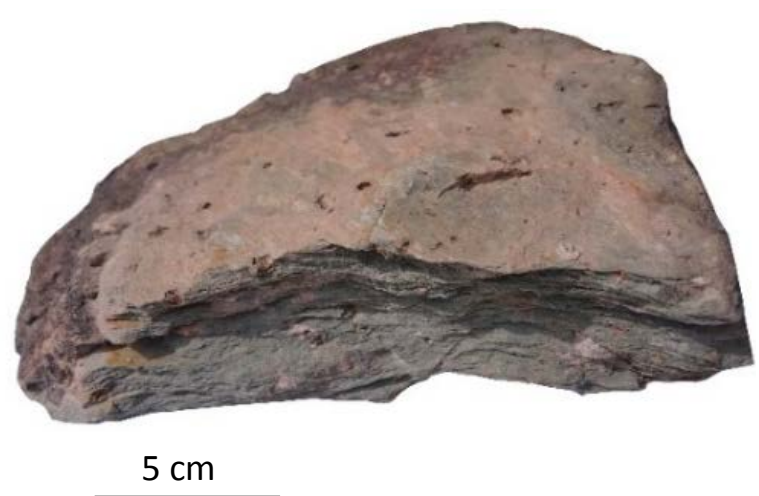

Figura 3.73 - Amostra de filito hematítico ocorrentes com heterogeneidades rosadas.

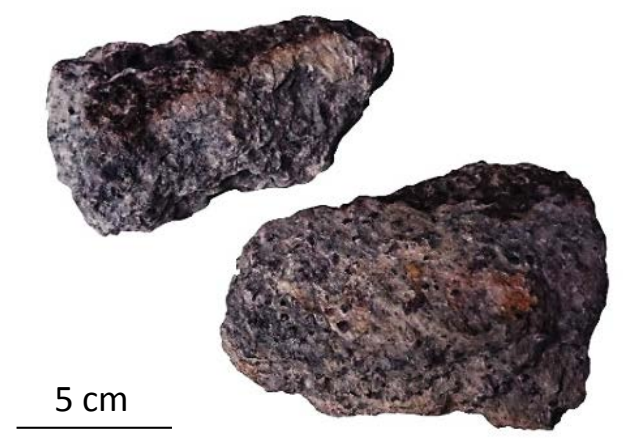

Figura 3.74 - Clastos angulosos de filito hematítico presentes no metaconglomerado.

\subsubsection{Campo Diamantífero São João da Chapada}

A área mineralizada São João da Chapada situa-se no divisor de águas, tendo do lado oeste o rio Pardo Grande na bacia do São Francisco e à leste os rios Caeté-Mirim, afluentes do Rio Jequitinhonha. Dentro da região ocorrem as formações São João da Chapada, Sopa Brumadinho e Galho do Miguel. A primeira ocorrência de diamante em depósitos secundários ocorreu nesta área, nas lavras Barro e Duro. As lavras Barro e Duro, Pagão, Campo Sampaio foram visitadas. A lavra Jobô encontra-se em operação, contudo, não foi autorizado acesso por parte dos responsáveis.

\section{Lavras Barro e Duro}

As lavras Barro e Duro (Figura 3.75) estão localizadas em área adjacente ao povoado São João da Chapada. A denominação das lavras é devido ao fato do material diamantífero ser friável na primeira e litificado na segunda. Adentrando à lavra Duro, que consiste na lavra meridional, verificou-se indícios de atividade garimpeira recente. Em seu interior é recorrente a presença de fragmentos de filito hematítico, na porção leste ocorrem rochas quartzíticas e em menor quantidade metaconglomerados remanescentes. A lavra Barro, localizada logo a norte da Duro, possui como litologia predominante metabrecha quartzítica (Figuras 3.76 e 3.77) com fragmentos de quartzito 
e filito hematítico. O filito hematítico friável de coloração rosa esbranquiçada aflora à oeste de ambas as lavras (Figura 3.78), enquanto o filito menos alterado de coloração cinza com concentrações de óxidos e porções sericitizadas ocorre de forma isolada (Figura 3.79).

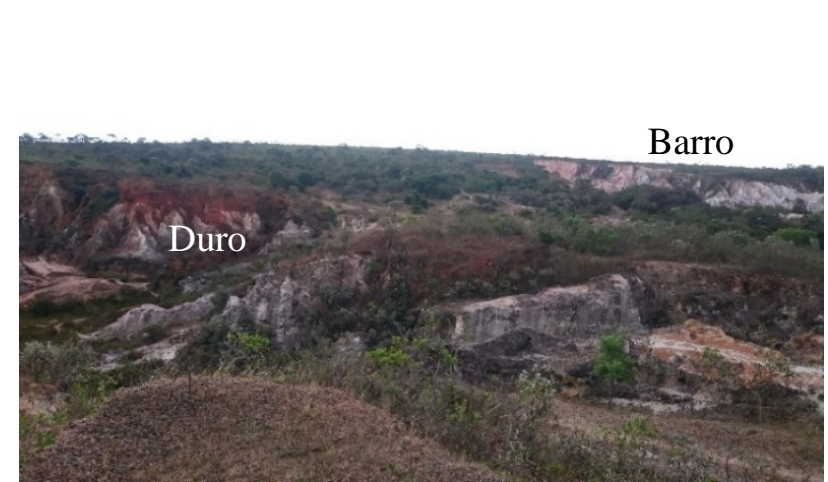

Figura 3.75 - Vista geral das lavras, Duro à frente e Barro ao fundo.

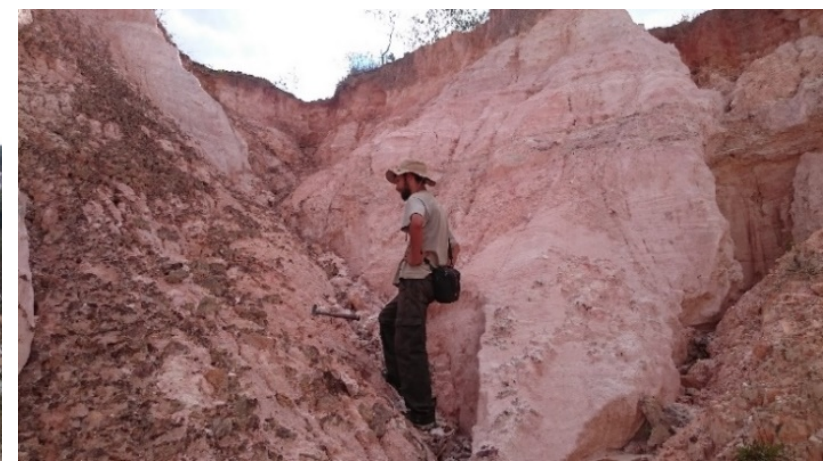

Figura 3.76 - Filito hematítico intercalado com níveis de metabrecha quartzítica.

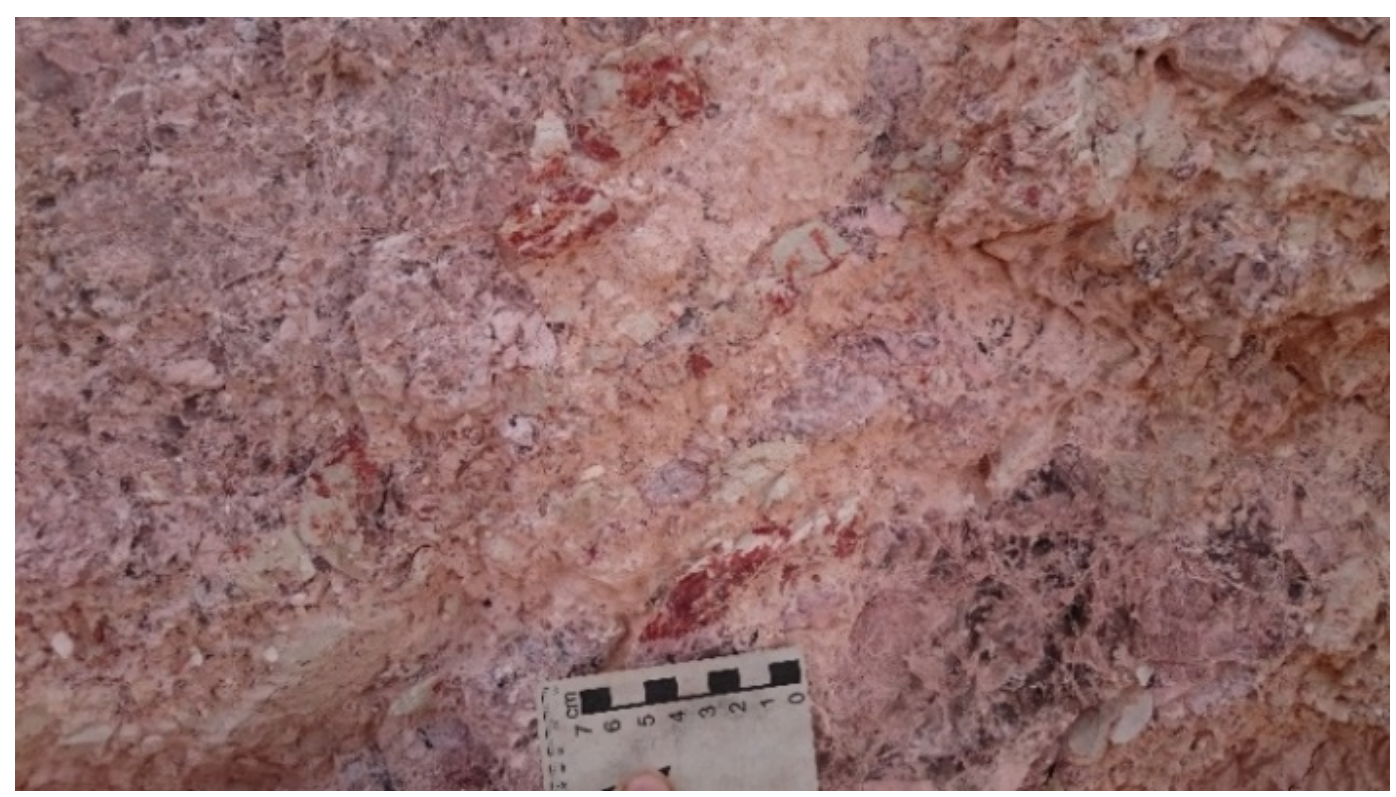

Figura 3.77 - Metabrecha quartzítica com fragmentos de quartzo e filito.

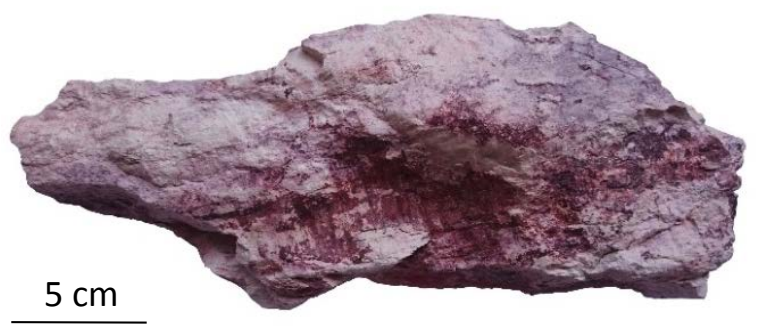

Figura 3.78 - Amostra do filito hematítico alterado, adquirindo coloração característica.

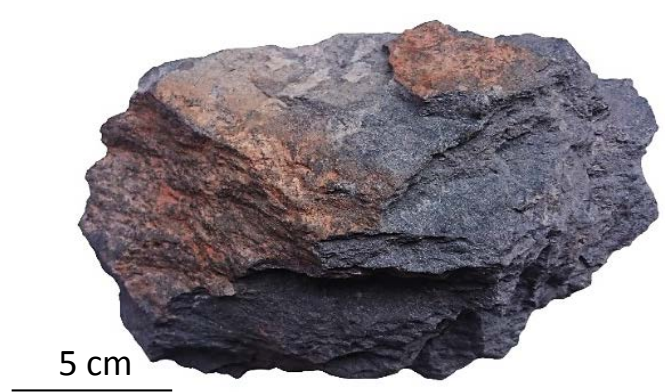

Figura 3.79 - Amostra do filito hematítico menos alterado. 


\section{Lavra Pagão}

A lavra Pagão (Figura 3.80) dista aproximadamente $4 \mathrm{~km}$ a oeste do povoado São João da Chapada. Consiste em uma depressão abrupta em local relativamente plano. Indícios de atividade garimpeira recente são observados na lavra. Filitos hematíticos afloram localmente com pseudomorfos tabulares, possivelmente feldspatos sericitizados (Figura 3.81). Na porção oeste da lavra o filito hematítico ocorre associado com a metabrecha quartzítica, ambos alterados e prováveis alvos da atividade garimpeira, uma vez que não foram observados volumes consideráveis de metaconglomerados.

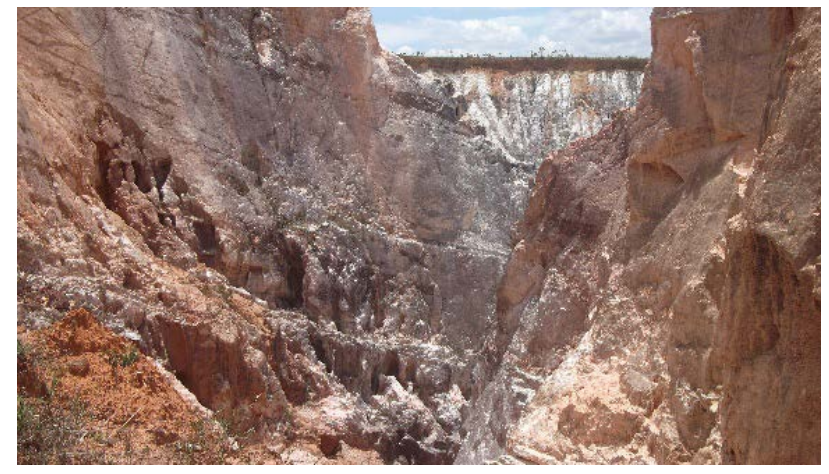

Figura 3.80 - Vista geral da lavra Pagão.

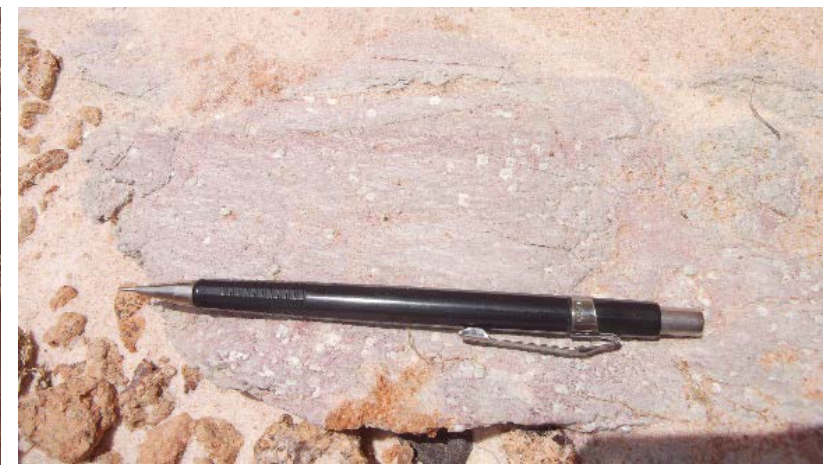

Figura 3.81 - Filito hematítico com minerais tabulares.

\section{Lavra Campo Sampaio}

A lavra Campo Sampaio (Figura 3.82) possui importância histórica na mineração de diamantes na região, sendo uma antiga área de atuação da empresa De Beers. Atualmente encontrase em processo de recuperação ambiental com o intuito de retomar atividade de lavra.

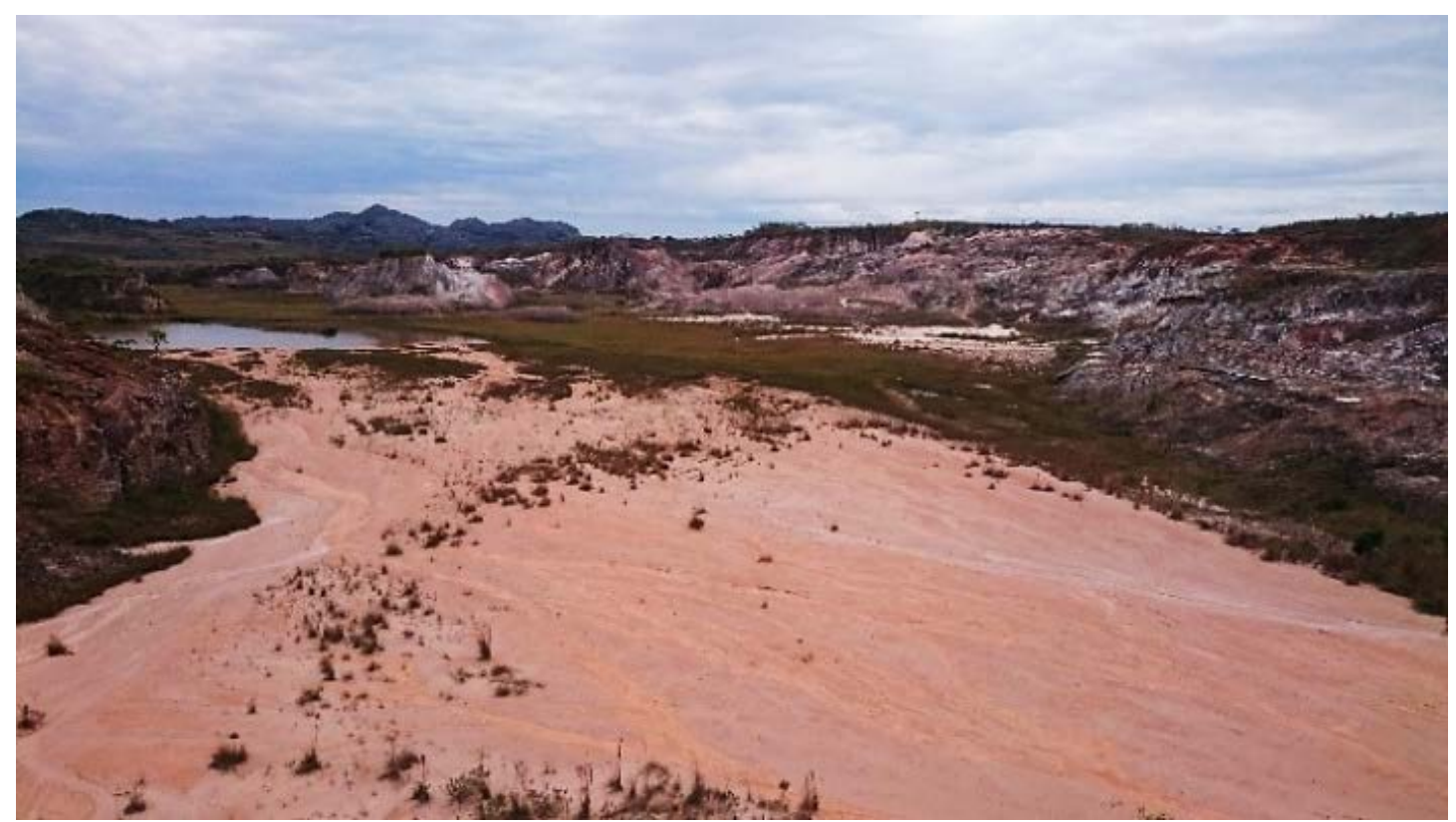

Figura 3.82- Vista geral da lavra Campo Sampaio. 
Devido à intensa atividade ocorrida no local, a dimensão da depressão seguiu as mesmas proporções. No interior da lavra há ocorrências localizadas de metabrecha quartzítica, porém é marcante a presença de uma rocha aflorante em área elevada remanescente no centro da lavra (Figura 3.83).

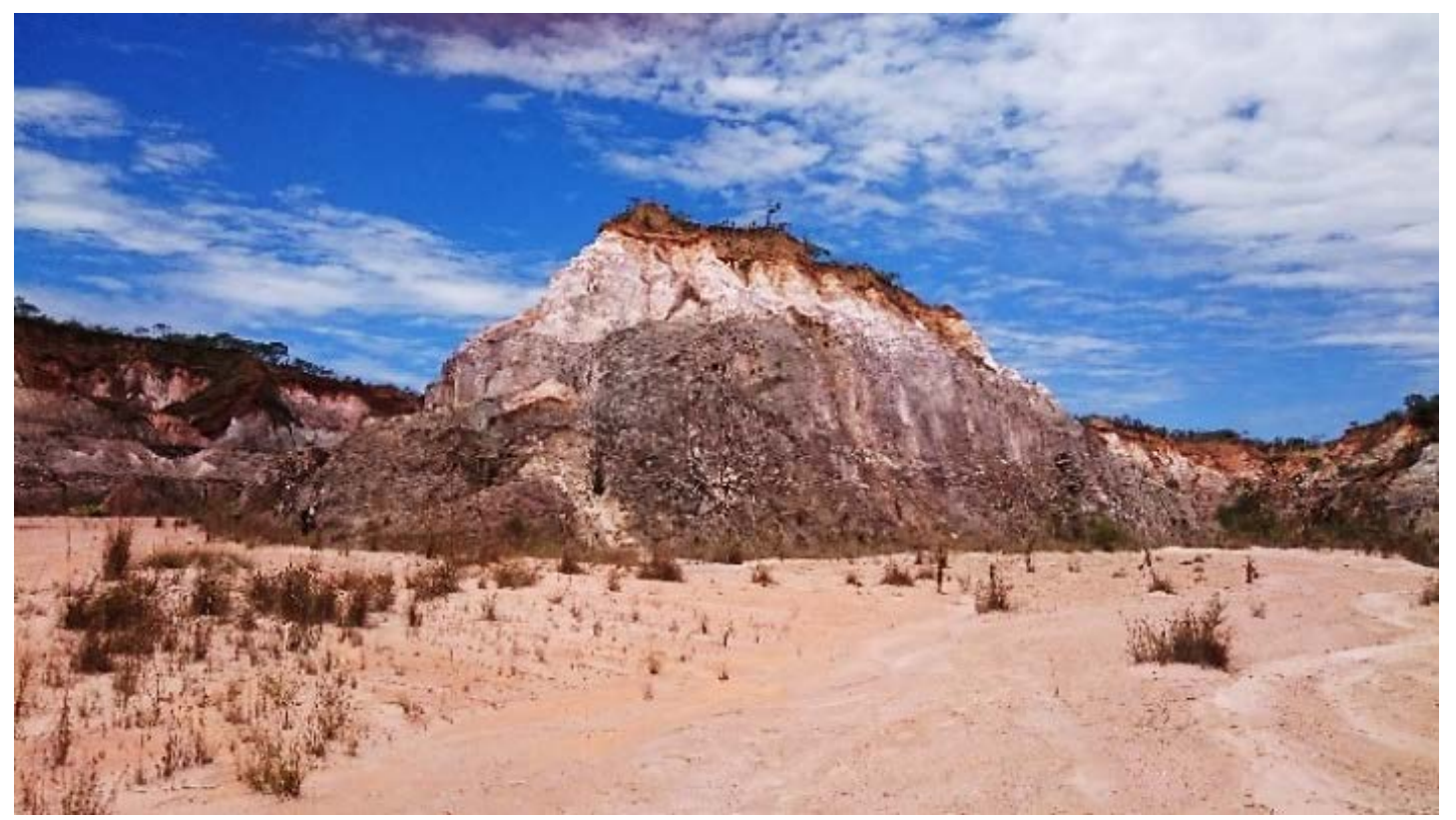

Figura 3.83- Pequeno morro localizado na porção central da lavra, local em que aflora o filito hematítico.

A rocha que aflora nesta porção elevada consiste no filito hematítico em nítida relação de corte com rochas quartzíticas. A ocorrência de um bloco métrico de quartzito envolto pelo filito evidencia a interação do magmatismo com as rochas encaixantes (Figura 3.84). A rocha destacase por apresentar feições que diferem dos demais filitos hematíticos, uma vez que possui coloração escura acompanhada de textura brechoidal, preservando fragmentos angulosos e nódulos, como pode ser observado nas Figuras 3.85 e 3.86. Sendo assim, o filito hematítico que ocorre na lavra Campo Sampaio aparenta preservar a textura original da rocha, tornando indiscutível seu caráter de brecha referente ao magmatismo precursor.

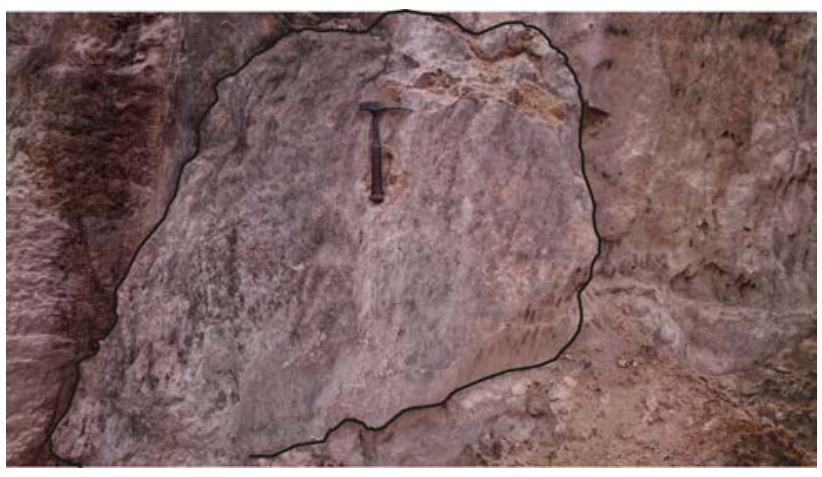

Figura 3.84 - Bloco de quartzito inserido no filito hematítico.

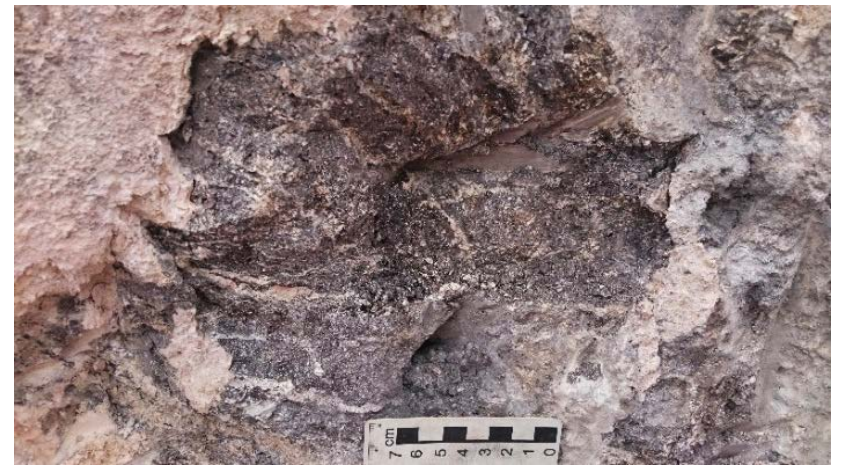

Figura 3.85 - Amostra do filito hematítico e suas heterogeneidades. 


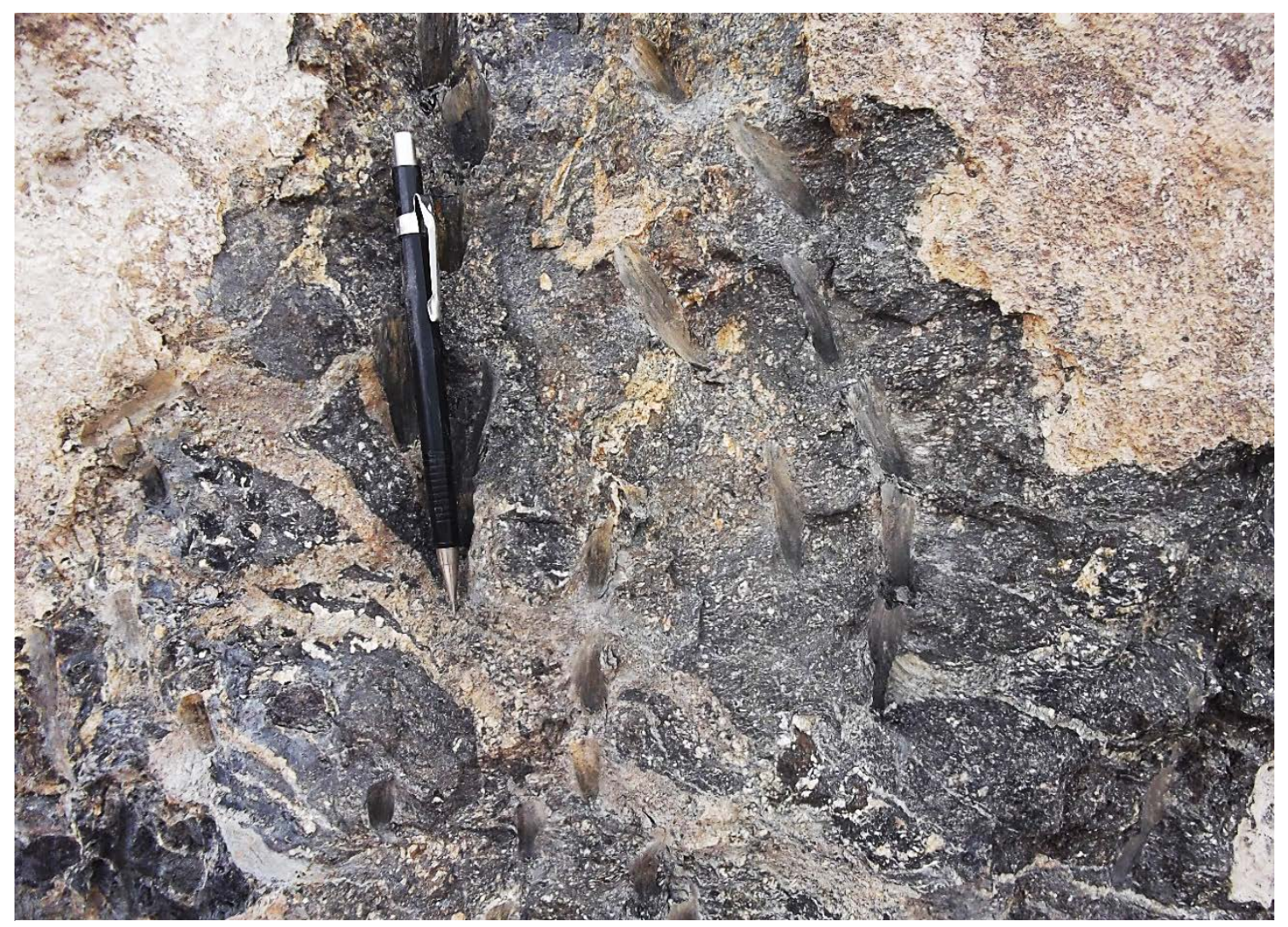

Figura 3.86 - Aparência geral do filito hematítico com textura brechada.

\subsection{4- Ocorrência Diamantífera em Macacos}

O povoado Macacos encontra-se a norte de São João da Chapada, sendo o local de lavra mais setentrional visitado neste trabalho. A área está localizada em ambiente com relevo acidentado, visivelmente distinto das demais lavras visitadas (Figura 3.87). Na estrada de acesso é possível observar indícios de garimpo sobre o filito hematítico. No povoado há histórico de ocorrência de diamantes, porém não há registros de metaconglomerados ou metabrechas quartzíticas. Segundo os habitantes, a “massa” não ocorre no local, sendo sua ocorrência restrita à sul, nas lavras Campo Sampaio e Jobô.

Após a descoberta de diamantes em metaconglomerados e metabrechas quartzíticas as lavras instalaram-se nos locais em que tais rochas afloram. Como estas rochas não ocorrem em Macacos, a presença de diamantes deve ser atribuída à outra rocha diamantífera. Em conversa com os habitantes locais, muitos dos quais participaram efetivamente do processo de lavra, a descoberta da ocorrência de diamantes foi casual após terem sido recuperados no interior de aves. A partir deste momento, iniciou-se lavra nos quintais das residências. Sendo assim, o diamante de Macacos é proveniente diretamente do filito hematítico, localmente denominado “Pedra de Fogo”. Em uma pequena área de garimpo abandonada adjacente às residências foi verificado que a única rocha aflorante consiste no filito hematítico, além disto, habitantes locais confirmaram que a rocha forneceu diamantes (Figuras 3.88 e 3.89). 


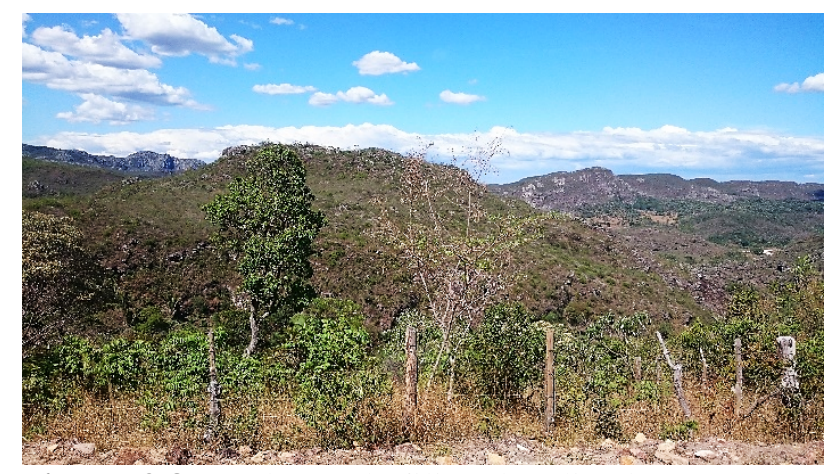

Figura 3.87 - Blocos de filitos localizados nas proximidades do povoado de Macacos.

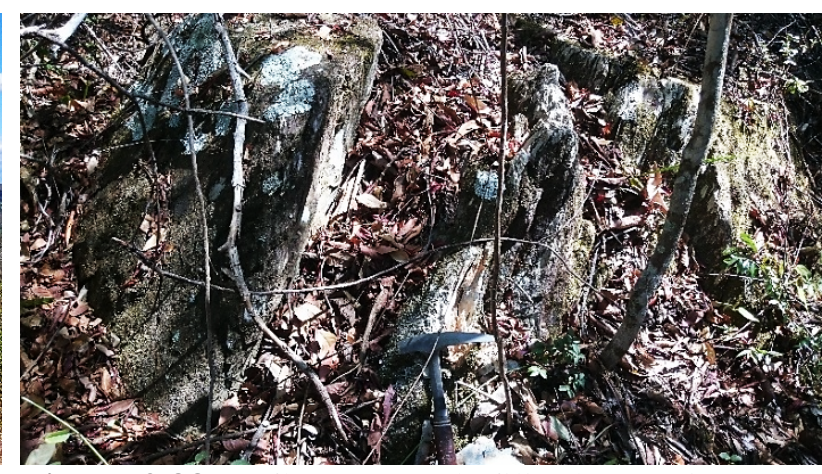

Figura 3.88 - Afloramento de filito hematítico em antigo local de lavra.

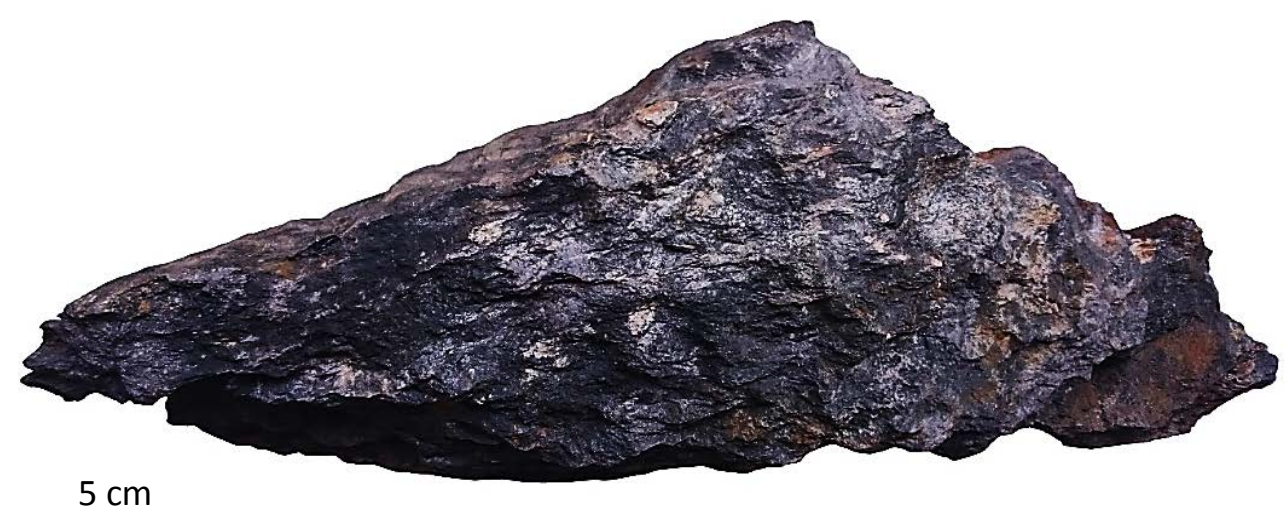

Figura 3.89 - Amostra do filito hematítico que ocorre no povoado Macacos.

O povoado está inserido na Formação São João da Chapada, logo é possível que parte do magmatismo precursor dos filitos hematíticos tenha ocorrido em porções distais do centro da atividade tectônica, local em que ocorreu maior sedimentação, referente à Formação Sopa Brumadinho, e que o filito hematítico ocorre de maneira mais abundante. Logo, os condicionantes geológicos não favoreceram a formação de conglomerados ou brechas quartzíticas em tais porções da bacia. O fato de não ocorrer "massa” e a lavra ser exclusivamente a partir do filito hematítico explica o motivo do garimpo na região não ter desenvolvido como nas demais áreas, além disto, o relevo acidentado não fornece condições ideais para intemperismo do filito hematítico, e desta maneira a rocha ocorrer quase que exclusivamente litificada, o que também dificulta o processo de lavra manual. A ocorrência de diamantes recuperados diretamente a partir do filito hematítico no povoado de Macacos e a ausência de demais litologias diamantíferas consiste em um argumento que corrobora a teoria de que o filito hematítico seja a rocha fonte dos diamantes da Serra do Espinhaço Meridional

\subsection{5 - Lavras Menores}

Lavras menores ocorrem dispersas em todos os campos diamantíferos visitados. Nas proximidades do povoado Sopa existem inúmeros locais em que já foi realizada atividade 
garimpeira, mesmo após décadas ainda é possível identificar antigas lavras. Todas as lavras apresentam exposições do filito hematítico (Figuras 3.90 a 3.93) adjacentes ao metaconglomerado diamantífero. Diversos locais isolados possuem como material alvo de garimpo o "gorgulho” ou material coluvionar. Um bom exemplo consiste na área denominada Tanque Paroquial, no povoado Sopa, localidade em que há ocorrência de filito hematítico associado com metaconglomerados.
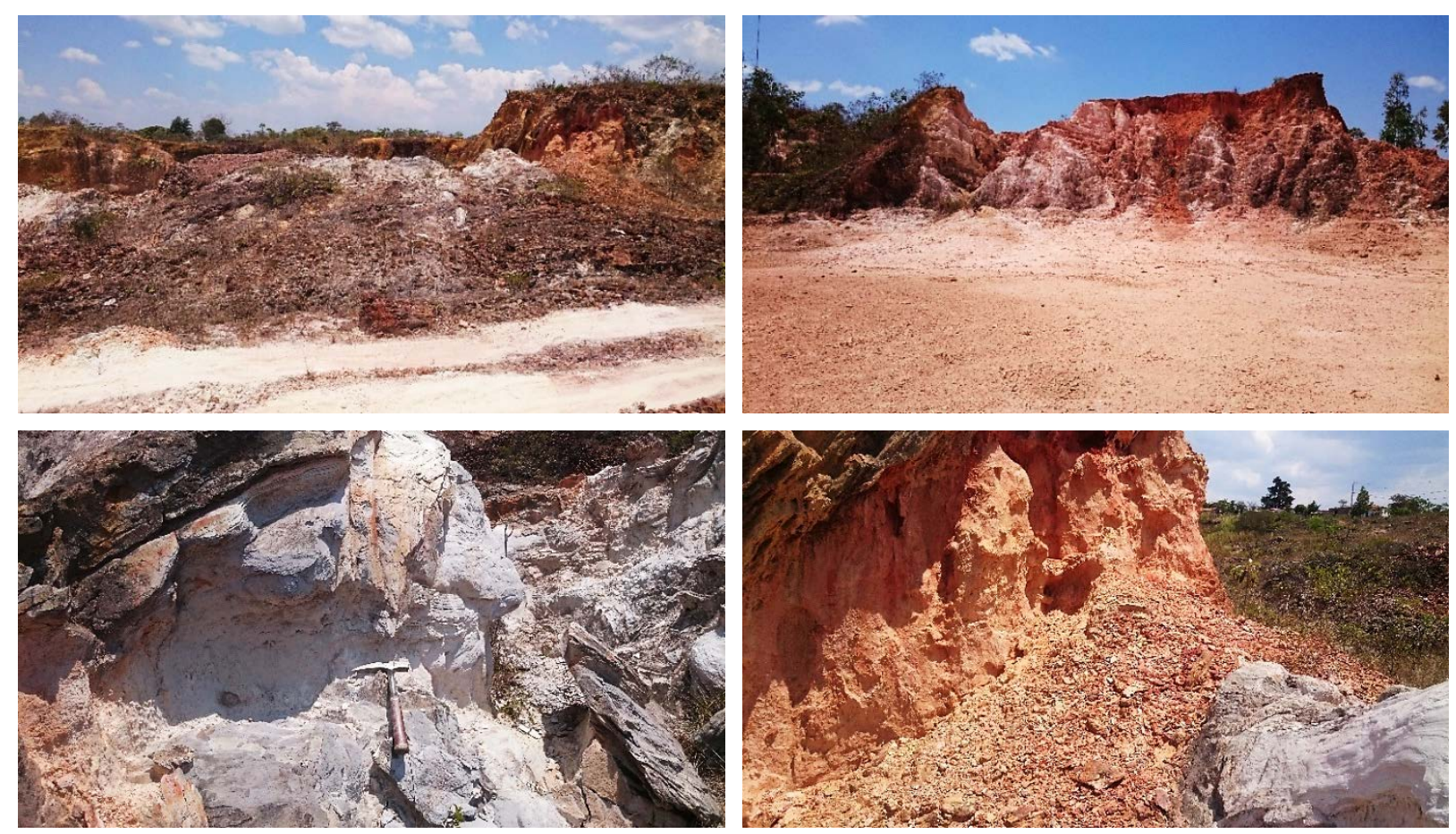

Figuras 3.90 a 3.93 - Lavras menores próximas ao povoado Sopa, o filito hematítico aflora em todos os locais, com diferentes texturas e graus de intemperismo. 


\section{CAPÍTULO 4}

\section{RESULTADOS ANALÍTICOS}

\section{1 - Mineralogia e Petrografia}

Como já descrito, os filitos hematíticos apresentam-se como rochas sericíticas de cor predominantemente cinza podendo apresentar variações de roxa, verde e preta. Em sua maioria possuem elevada densidade e nódulos de óxidos de Fe/Ti. Turmalina ocorre como importante mineral acessório, enquanto cristais de magnetita estão presentes de forma restrita, demais minerais são de difícil identificação, exceto sombras de minerais tabulares, interpretados como resultado da sericitização de feldspatos. Os filitos hematíticos apresentam grandes quantidades de zircão, o que foi verificado ao preparar as amostras para análise geocronológica, contudo consistem em sua maioria de origem secundária, ou seja, representam contaminação a partir das rochas encaixantes.

Em seção delgada as rochas exibem mineralogia simples, composta quase que exclusivamente por sericita/muscovita e óxidos de Fe/Ti, com predomínio de hematita. Quartzo ocorre em quantidade reduzida, não ultrapassando 5\%. Em sua maioria, as rochas apresentam quantidades equivalentes de sericita e óxidos, preferencialmente dispostos com textura equigranular (Figuras 4.1 e 4.2). Apesar da assembleia mineralógica simples, os filitos hematíticos exibem significativas variações texturais, assim como na macroscopia.

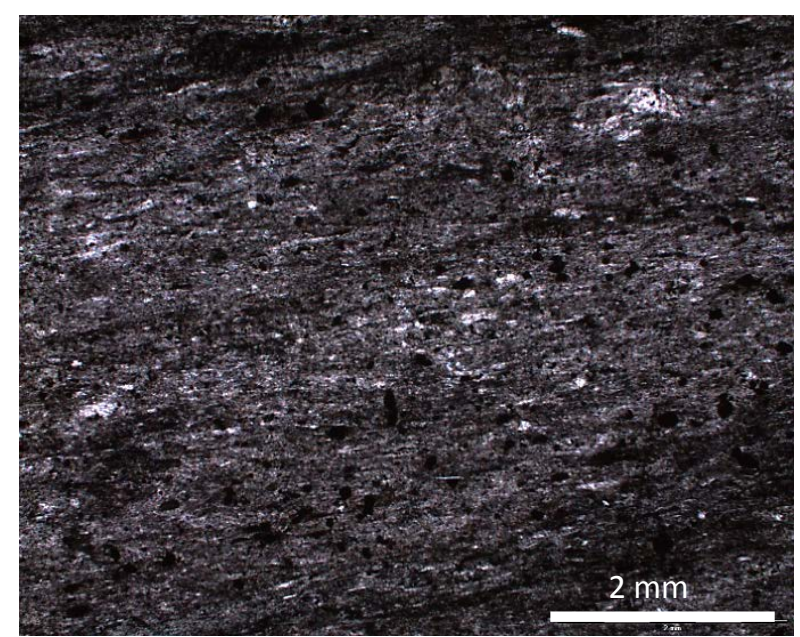

Figura 4.1 - Lâmina de filito hematítico da lavra Brumadinho, textura equigranular composta por cristais de sericita e óxidos.

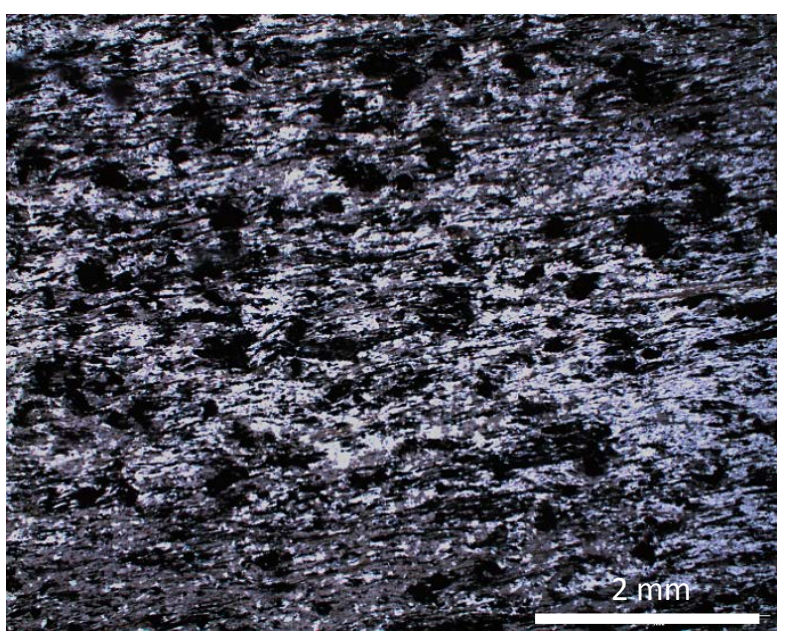

Figura 4.2 - Lâmina de filito hematítico localizado nas proximidades do povoado Sopa, textura eauigranular.

Duas gerações de lamelas de muscovitas são visualizadas, a primeira ocorre na forma de cristais estirados com sobreposição de óxidos (Figura 4.3) e a segunda, visivelmente posterior, sucede sem deformação (Figura 4.4). 


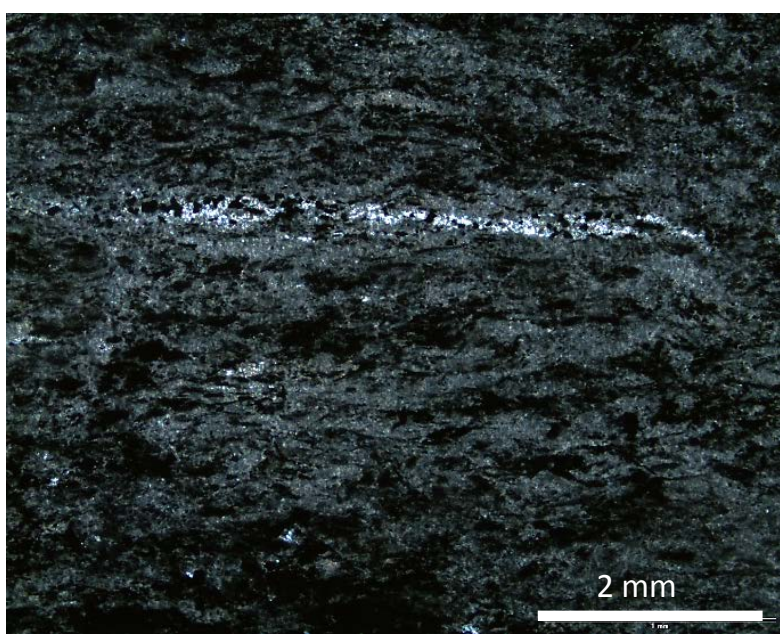

Figura 4.3 - Lâmina de filito da lavra Campo Sampaio exibindo cristal estirado de sericita com sobreposição de óxidos.

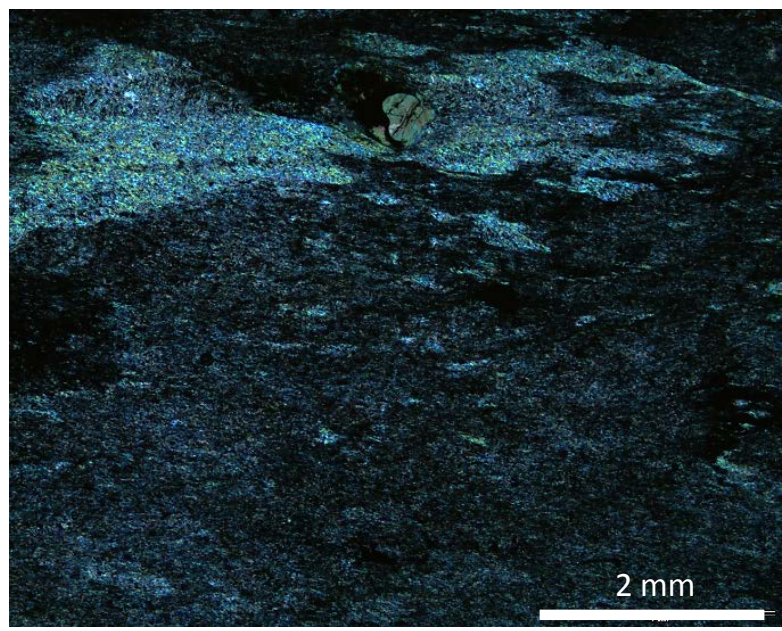

Figura 4.4 - Lâmina de filito da lavra Brumadinho indicando a existência de duas gerações de muscovita na porção superior da lâmina.

Os cristais maiores de sericita sugerem a existência de fenocristais sericitizados (Figura 4.5). Cristais de óxidos em matriz predominantemente sericítica também são recorrentes, evidenciando processo de oxidação do filito hematítico (Figura 4.6). O grau de deformação é variável, com foliação desde ausente (Figura 4.7) à proeminente (Figura 4.8), marcada principalmente pelos cristais de sericita. Turmalina ocorre preferencialmente no interior dos filossilicatos, localmente exibindo textura fluidal, explicando assim sua gênese a partir de fluídos metassomáticos.

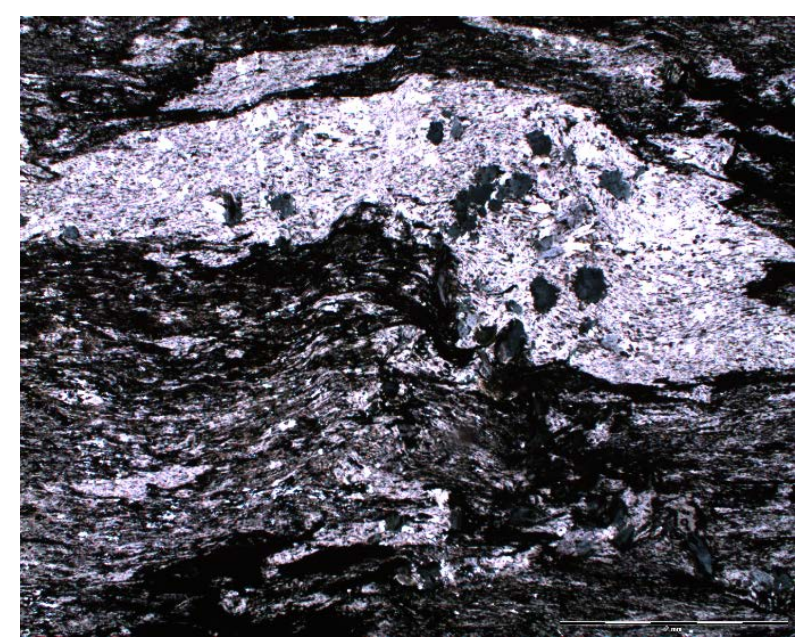

Figura 4.5 - Lâmina de amostra da lavra próxima ao Povoado Macacos, motrando fenocristal sericitizado com turmalina em seu interior.

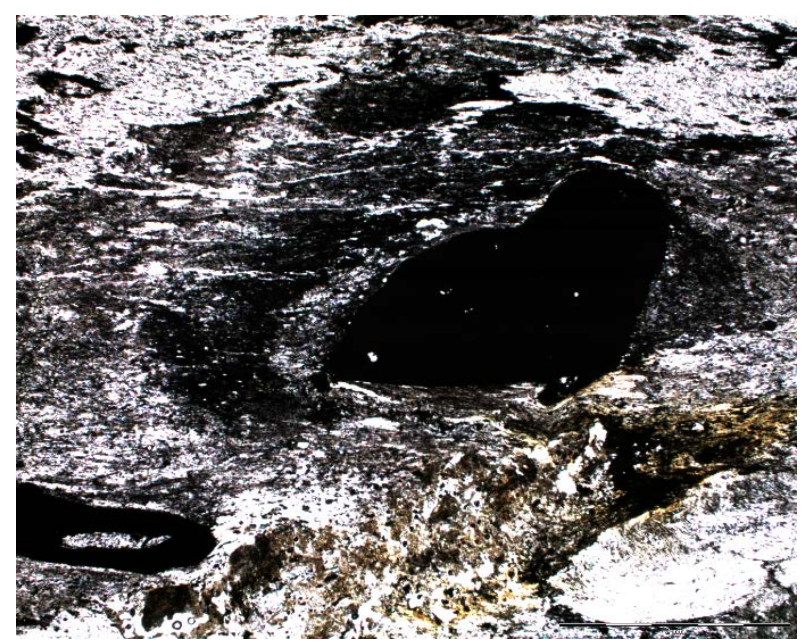

Figura 4.6 - Lâmina de filito de amostra da lavra Brumadinho, matriz sericítica com cristais maiores de óxidos. 


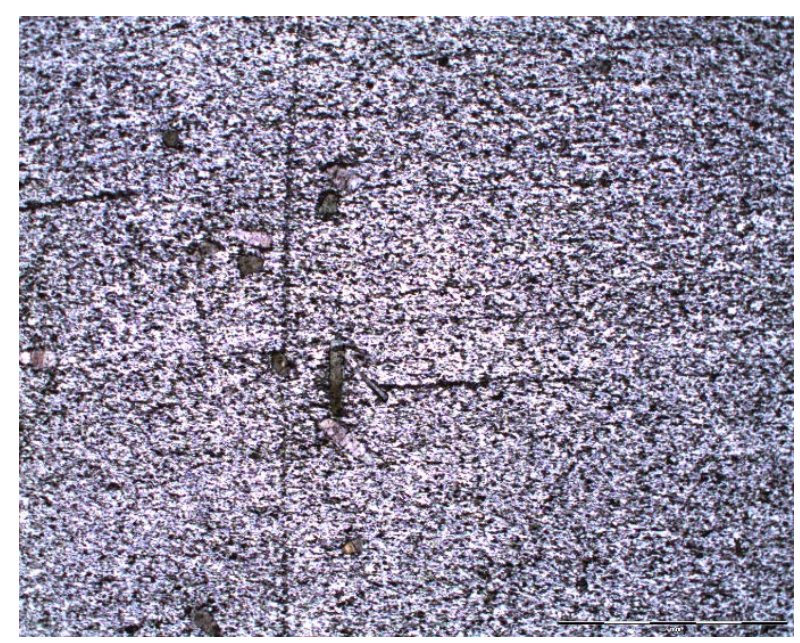

Figura 4.7 - Lâmina de filito hematítico de rocha coletada localizado ao Povoado Macacos, rocha sem foliação.

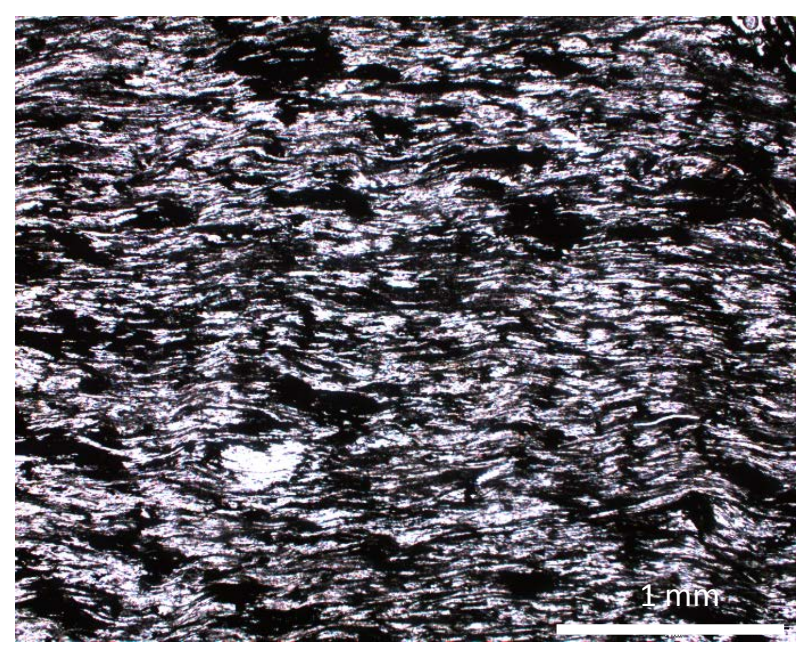

Figura 4.8 - Lâmina de filito hematítico localizado próximo ao Povoado Sopa, destaque para a foliação proeminente.

Os cristais de sericita podem apresentar crenulação em amostras com maior deformação (Figura 4.9). A amostra proveniente da lavra Caldeirões, de coloração esverdeada, possui clorita como mineral principal (70\%), seguida por sericita e óxidos (Figura 4.10).

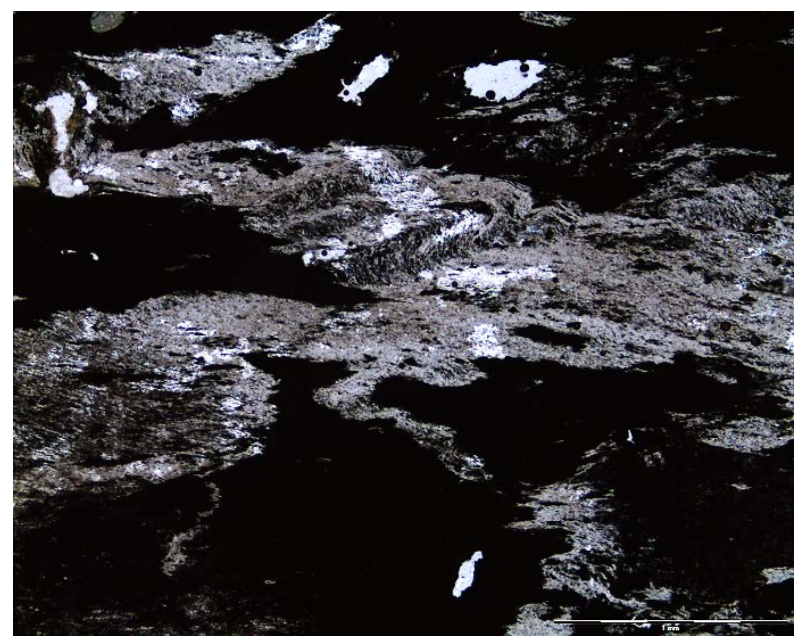

Figura 4.9 - Lâmina de filito hematítico da lavra Brumadinho, matriz rica em sericita com microdobras.

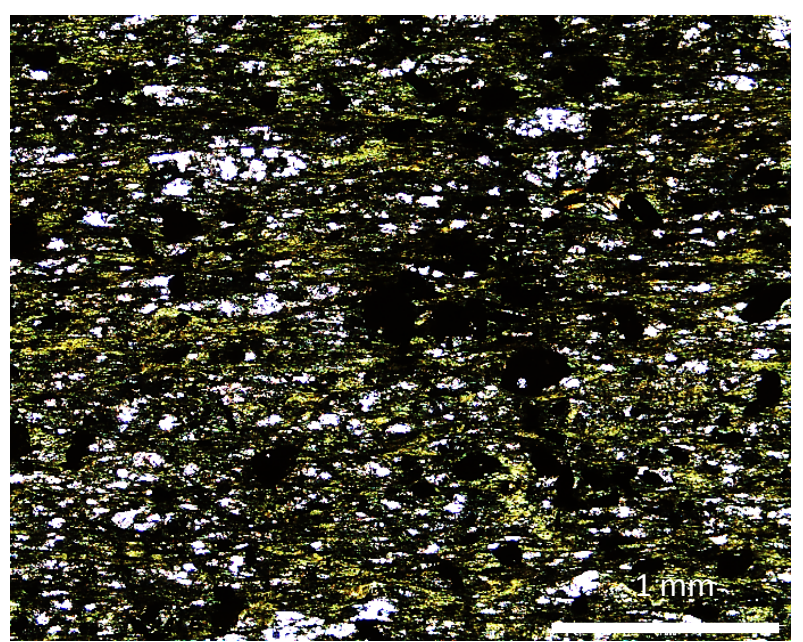

Figura 4.10 - Lâmina de filito hematítico da lavra Caldeirões, composta por clorita, óxidos e sericita.

As seções delgadas dos filitos hematíticos da lavra Campo Sampaio foram impregnadas devido à condição friável da amostra. Em tais lâminas fica evidente a textura porfirítica, ilustrando o caráter brechado da rocha, e esta rocha é considerda a melhor representação textural da rocha precursora do filito hematítico (Figuras 4.11 e 4.12). 


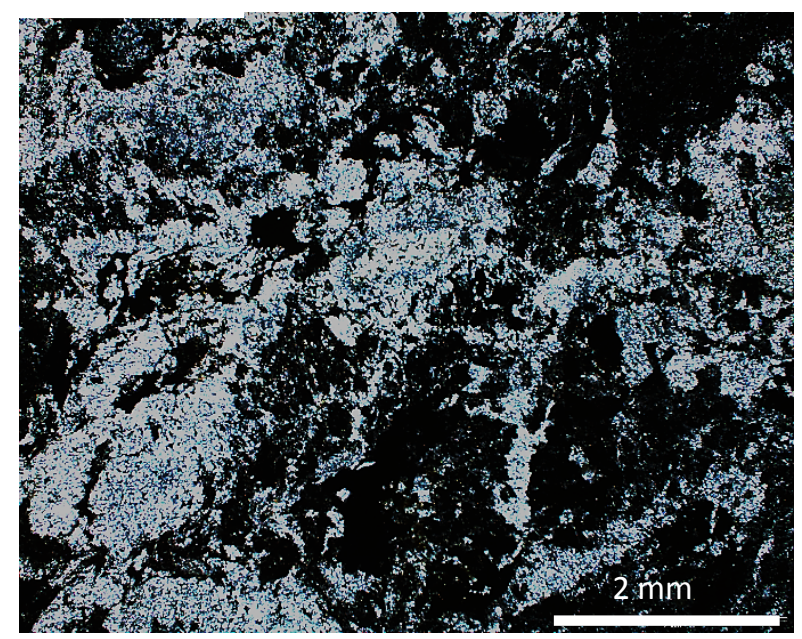

Figura 4.11 - Seção delgada de amostra de filito da Lavra Campo Sampaio indicando a textura brechada da rocha.

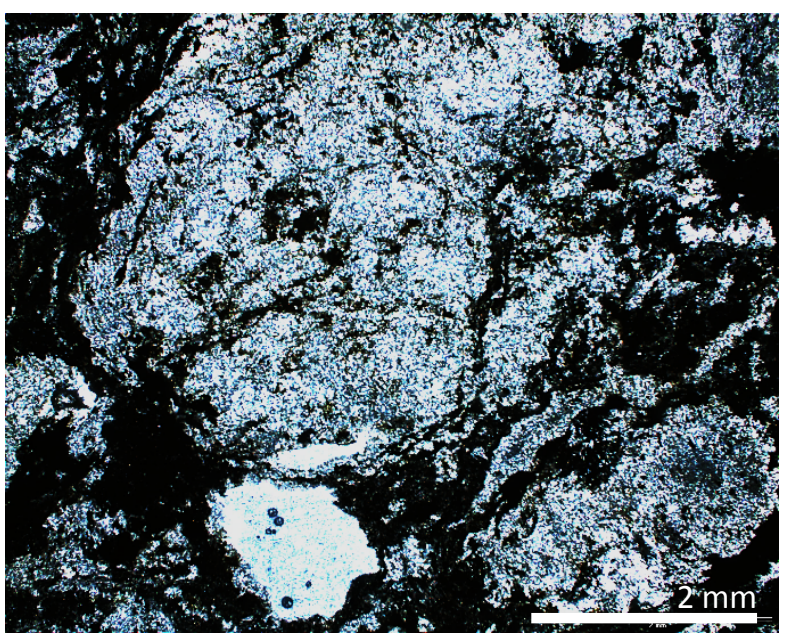

Figura 4.12 - Lâmina de amostra de filito hematítico da lavra Campo Sampaio com textura porfirítica.

\section{2 - Geoquímica}

Apesar da diversidade de fácies observadas nos filitos hematíticos, os resultados geoquímicos da rocha mantêm-se praticamente constantes. Resultados geoquímicos presentes na literatura serão aqui compilados à título de comparação, entretanto, os dados obtidos neste trabalho exibem semelhanças com os disponíveis na bibliografia. Tal fato pode estar relacionado com a mineralogia simples do filito hematítico, composta basicamente por sericita/muscovita e óxidos de $\mathrm{Fe} / \mathrm{Ti}$.

Um dos principais questionamentos a respeito da evolução da Bacia Espinhaço consiste na origem e significado dos filitos hematíticos. A discussão já levou a suposição do magma original ser ácido (Moraes \& Guimarães, 1930), intermediário (Correns 1932), traquítico (Barbosa, 1951), básico (Scholl \& Fogaça, 1981; Knauer \& Schrank, 1993) e ultrabásico (Herrgesell, 1984).

A natureza discutível deste magmatismo e sua correlação com a ocorrência de diamantes possibilitou uma quantidade razoável de análises químicas na bibliografia, desta forma, Knauer \& Schrank (1993) selecionaram resultados típicos e formularam um “filito padrão” com a composição apresentada na Tabela 4.3.

Tabela 4.3- Composição do filito hematítico padrão segundo Knauer e Schrank (1993).

\begin{tabular}{|c|c|c|c|c|c|c|c|c|c|}
$\mathrm{SiO}_{2}$ & $\mathrm{TiO}_{2}$ & $\mathrm{Al}_{2} \mathrm{O}_{3}$ & $\mathrm{FeO}$ (tot) & $\mathrm{MnO}$ & $\mathrm{MgO}$ & $\mathrm{CaO}$ & $\mathrm{Na}_{2} \mathrm{O}$ & $\mathrm{K}_{2} \mathrm{O}$ & $\mathrm{P}_{2} \mathrm{O}_{5}$ \\
\hline 35,4 & 5,4 & 23,3 & 25,3 & 0,1 & 1,5 & 0,5 & 0,3 & 7,9 & 0,4 \\
\hline
\end{tabular}

Os resultados obtidos pelos autores mostram que em termos de elementos maiores o filito padrão, quando comparado com valores médios da crosta terrestre, apresenta-se enriquecido em vanádio (178ppm), gálio (37ppm), rubídio (140ppm), ítrio (158ppm), zircônio (544ppm), nióbio (117 ppm), boro (1380 ppm) e itérbio (12 ppm). Valores relativamente baixos são verificados para 
os elementos cromo (16 ppm), cobalto (18 ppm), níquel (37 ppm) e estrôncio (297 ppm). Desta forma, os dados geoquímicos exibem resultados incongruentes com rochas ígneas típicas.

Filitos hematíticos analisados por Dussin (1994) exibem valores elevados de $\mathrm{K}_{2} \mathrm{O}$ (4,5 a 9,2\%), $\mathrm{TiO}_{2}$ (4,0 a 6,7\%), $\mathrm{Al}_{2} \mathrm{O}_{3}$ (18,5 a 23,8\%), $\mathrm{FeO}$ (16,7 a 37,0\%) e valores reduzidos de $\mathrm{SiO}_{2}$ (28,3 a 40,7\%), $\mathrm{Na}_{2} \mathrm{O}(0,1$ a $1,5 \%), \mathrm{CaO}(<1,7 \%)$ e $\mathrm{MgO}$ (traços a 8,5\%).

Segundo Cabral et al. (2012) o filito hematítico representa alteração de rocha basáltica, constituindo paleossolos que foram subsequentemente metamorfisados. Os autores não comprovam origem do filito hematítico a partir de paleossolos, contudo é proposto que o filito seja derivado de basaltos e riolitos com ação de fluídos metamórficos de origem continental enriquecidos em potássio e boro após a deformação Brasiliana, o que explicaria a presença recorrente de turmalina.

Knauer (1990) também defende que o filito hematítico seja derivado de paleossolos, resultado de alterações superficiais Pré-Cambrianas. Segundo o autor, tal condição explica a perda de $\mathrm{SiO}_{2}, \mathrm{MgO}$, $\mathrm{CaO}$ e $\mathrm{Na}_{2} \mathrm{O}$ assim como o enriquecimento em $\mathrm{K}_{2} \mathrm{O}$ e $\mathrm{TiO}_{2}$. Novoselov \& Filho (2012) elaboraram modelos de paleossolos Pré-Cambrianos, em que as mudanças intra-elementais estariam relacionadas com fluídos metassomáticos atuando por períodos de 500 mil anos, o que não pode ser verificado nos solos recentes. O modelo explica o enriquecimento em potássio, a mobilidade dos elementos $\mathrm{Ca}, \mathrm{Mg}$ e $\mathrm{Na}$ e pode ser aplicado na reconstrução de paleossolos e paleoatmosferas.

No presente trabalho são apresentados resultados analíticos de 6 amostras do filito hematítico, a fim de efetuar análises representativas foram selecionadas rochas de diferentes texturas, atentando-se à analisar filitos nitidamente de origem ígnea. Apesar das diferenças em campo, os resultados obtidos mostram-se uniformes, fornecendo valores elevados de $\mathrm{K}_{2} \mathrm{O}$, $\mathrm{TiO}_{2}$ e $\mathrm{FeO}$ assim como baixas concentrações de $\mathrm{SiO}_{2}, \mathrm{Na}_{2} \mathrm{O}$ e $\mathrm{CaO}$.

Em todas as análises do filito hematítico, os resultados apresentam elevados valores de titânio, típico de rochas lamproíticas, que possuem uma série de minerais titaníferos. O boro também ocorre com valores elevados, coerente com a presença de turmalina, mineral comum em rochas metamórficas de origem kimberlíticas/lamproíticas, como exemplo, os metakimberlitos do Gabão. Durante os processos de alteração da rocha houve empobrecimento dos elementos de maior mobilidade e enriquecimento de determinados elementos imóveis. Comparar a geoquímica de elementos traços do filito com geoquímica de rocha que não passou por tais processos metamórficos, metassomáticos e intempéricos é discutível, uma vez que é possível ocorrer redistribuição até mesmo dos elementos terras raras sob tais condições. 
A Tabela 4.4 exibe os resultados obtidos neste trabalho enquanto a Tabela 4.5 compara com a média de resultados disponíveis na literatura.

Tabela 4.4 - Resultados geoquímicos de filitos hematíticos analisados neste trabalho. Elementos maiores em \% e elementos traços em ppm.

\begin{tabular}{|c|c|c|c|c|c|c|}
\hline & Brumadinho & Caldeirões & Caldeirões II & Sopa & Macacos & Macacos II \\
\hline $\mathrm{SiO2}$ & 40,83 & 47,04 & 39,05 & 34,44 & 46,88 & 31,36 \\
\hline $\mathrm{Al} 2 \mathrm{O} 3$ & 26,69 & 13,53 & 27,82 & 23,99 & 27,40 & 20,95 \\
\hline Fe2O3 & 14,80 & 15,40 & 16,40 & 23,93 & 5,61 & 23,58 \\
\hline MgO & 1,86 & 10,10 & 1,29 & 1,05 & 2,76 & 1,49 \\
\hline $\mathrm{CaO}$ & 0,02 & 0,49 & 0,04 & $<0.01$ & 0,02 & 3,23 \\
\hline $\mathrm{Na2O}$ & 0,30 & $<0.01$ & 0,36 & 0,31 & 0,16 & 0,20 \\
\hline K2O & 9,36 & $<0.01$ & 8,91 & 8,04 & 10,79 & 7,10 \\
\hline TiO2 & 1,12 & 4,15 & 1,05 & 3,74 & 0,78 & 5,23 \\
\hline P205 & 0,02 & 0,60 & 0,07 & 0,02 & 0,06 & 2,43 \\
\hline $\mathrm{MnO}$ & 0,10 & 0,14 & 0,05 & 0,05 & 0,07 & 0,01 \\
\hline Cr2O3 & 0,012 & $<0.002$ & 0,009 & 0,003 & $<0.002$ & 0,002 \\
\hline LOI & 4,4 & 8,3 & 4,4 & 4,1 & 5,0 & 4,1 \\
\hline Total & 99,51 & 99,75 & 99,45 & 99,67 & 99,53 & 99,68 \\
\hline TOT/C & $<0.02$ & 0,02 & 0,02 & 0,04 & 0,03 & 0,03 \\
\hline TOT/S & $<0.02$ & $<0.02$ & $<0.02$ & $<0.02$ & $<0.02$ & $<0.02$ \\
\hline $\mathrm{Au}$ & 2,4 & 0,9 & $<0.5$ & $<0.5$ & $<0.5$ & 1,1 \\
\hline $\mathrm{Ag}$ & $<0.1$ & $<0.1$ & 0,1 & $<0.1$ & $<0.1$ & $<0.1$ \\
\hline $\mathrm{Ba}$ & 1961 & 7 & 3131 & 1069 & 1358 & 354 \\
\hline $\mathrm{Be}$ & 12 & $<1$ & 3 & 4 & 2 & 3 \\
\hline $\mathbf{B i}$ & 0,2 & $<0.1$ & 0,2 & $<0.1$ & $<0.1$ & 0,2 \\
\hline Co & 47,5 & 37,9 & 22,9 & 28,5 & 19,0 & 7,2 \\
\hline Cs & 5,2 & 0,7 & 1,6 & 2,7 & 1,0 & 0,9 \\
\hline $\mathrm{Cu}$ & 0,5 & 2,8 & 0,7 & 0,6 & 0,3 & 1,2 \\
\hline $\mathrm{Ga}$ & 32,3 & 23,3 & 30,4 & 35,7 & 25,8 & 28,7 \\
\hline Hf & 20,6 & 6,6 & 10,0 & 10,2 & 33,4 & 10,9 \\
\hline $\mathrm{Hg}$ & 0,02 & $<0.01$ & 0,01 & $<0.01$ & $<0.01$ & $<0.01$ \\
\hline Mo & 0,3 & 0,4 & 5,4 & $<0.1$ & $<0.1$ & $<0.1$ \\
\hline $\mathrm{Nb}$ & 24,8 & 21,1 & 19,3 & 20,5 & 13,9 & 39,5 \\
\hline $\mathrm{Ni}$ & 39 & 23 & 30 & 35 & $<20$ & $<20$ \\
\hline $\mathrm{Pb}$ & 75,4 & 1,6 & 9,6 & 8,5 & 3,2 & 3,1 \\
\hline $\mathbf{R b}$ & 131,0 & 1,2 & 113,4 & 87,6 & 132,9 & 72,7 \\
\hline $\mathrm{Sb}$ & 0,3 & $<0.1$ & $<0.1$ & $<0.1$ & $<0.1$ & 0,1 \\
\hline Sc & 22 & 40 & 22 & 51 & 5 & 45 \\
\hline Sn & 5 & 2 & 5 & 3 & 3 & 3 \\
\hline $\mathrm{Sr}$ & 90,6 & 8,7 & 214,7 & 163,4 & 34,7 & 94,9 \\
\hline $\mathrm{Ta}$ & 1,7 & 0,8 & 1,5 & 1,0 & 1,8 & 2,1 \\
\hline Th & 29,2 & 2,5 & 25,0 & 7,7 & 40,4 & 10,6 \\
\hline $\mathbf{U}$ & 13,9 & 0,8 & 4,8 & 1,8 & 12,0 & 12,0 \\
\hline V & 379 & 384 & 255 & 242 & 152 & 118 \\
\hline $\mathbf{w}$ & 4,1 & $<0.5$ & 2,7 & 8,3 & 5,8 & 4,1 \\
\hline $\mathrm{Zn}$ & 5 & 482 & 2 & 4 & 2 & 2 \\
\hline $\mathrm{Zr}$ & 811,3 & 251,1 & 392,6 & 371,7 & 1204,3 & 464,8 \\
\hline $\mathbf{Y}$ & 40,0 & 66,9 & 42,8 & 35,8 & 24,4 & 190,7 \\
\hline La & 95,0 & 24,3 & 103,0 & 49,8 & 227,2 & 216,6 \\
\hline $\mathrm{Ce}$ & 174,9 & 64,6 & 185,8 & 107,7 & 324,6 & 207,2 \\
\hline $\mathrm{Pr}$ & 18,04 & 8,67 & 18,83 & 11,49 & 41,16 & 47,91 \\
\hline Nd & 64,3 & 44,4 & 67,0 & 44,3 & 132,8 & 204,6 \\
\hline Sm & 11,59 & 12,78 & 12,11 & 8,48 & 15,74 & 41,71 \\
\hline Eu & 1,89 & 3,86 & 2,43 & 1,89 & 2,26 & 9,77 \\
\hline Gd & 7,94 & 15,26 & 10,84 & 7,35 & 9,01 & 41,44 \\
\hline Tb & 1,12 & 2,41 & 1,57 & 1,17 & 1,01 & 6,28 \\
\hline Dy & 6,79 & 14,08 & 8,28 & 6,97 & 4,95 & 35,92 \\
\hline Ho & 1,40 & 2,69 & 1,64 & 1,52 & 0,94 & 7,16 \\
\hline $\mathrm{Er}$ & 4,34 & 7,22 & 4,53 & 4,36 & 3,14 & 18,57 \\
\hline $\mathrm{Tm}$ & 0,71 & 1,04 & 0,67 & 0,68 & 0,54 & 2,54 \\
\hline Yb & 4,70 & 6,47 & 4,21 & 4,50 & 4,00 & 15,08 \\
\hline Lu & 0,75 & 0,99 & 0,67 & 0,74 & 0,70 & 2,08 \\
\hline
\end{tabular}


Tabela 4.5 - Comparativo dos resultados geoquímicos médios de filitos hematíticos por diferentes autores.

\begin{tabular}{|c|c|c|c|c|}
\hline & $\begin{array}{c}\text { Bezerra Neto } \\
\text { (2016) }\end{array}$ & $\begin{array}{l}\text { Cabral et al. } \\
\text { (2012) }\end{array}$ & $\begin{array}{l}\text { Battillani \& Guerra } \\
\text { (2006) }\end{array}$ & $\begin{array}{c}\text { Knauer \& Schrank } \\
\text { (1993) }\end{array}$ \\
\hline SiO2 & 39,93 & 39,92 & 40,08 & 33,30 \\
\hline Al2O3 & 23,40 & 25,15 & 24,91 & 21,74 \\
\hline $\mathrm{Fe} 2 \mathrm{O} 3$ & 16,62 & 14,66 & 18,71 & 26,34 \\
\hline MgO & 3,09 & 1,83 & 1,28 & 1,28 \\
\hline $\mathrm{CaO}$ & 0,76 & 0,02 & 0,14 & 0,15 \\
\hline $\mathrm{Na2O}$ & 0,27 & 0,19 & 0,18 & 0,25 \\
\hline K2O & 8,84 & 9,10 & 8,14 & 7,68 \\
\hline TiO2 & 2,68 & 3,29 & 2,58 & 4,78 \\
\hline P2O5 & 0,53 & 0,21 & 0,26 & 0,13 \\
\hline MnO & 0,07 & 0,04 & 0,01 & 0,03 \\
\hline Cr2O3 & 0,01 & 0,01 & - & - \\
\hline LOI & 5,05 & 5,13 & 3,75 & 3,64 \\
\hline Total & 101,25 & 99,54 & 100,02 & 100,39 \\
\hline TOT/C & 0,03 & 0,04 & - & - \\
\hline $\mathrm{Au}$ & 1,47 & 2,50 & - & - \\
\hline $\mathrm{Ag}$ & 0,10 & - & - & - \\
\hline $\mathrm{Ba}$ & 1313,33 & 1799,50 & 637,70 & - \\
\hline $\mathrm{Be}$ & 4,80 & 5,33 & - & - \\
\hline $\mathrm{Bi}$ & 0,20 & 0,10 & - & - \\
\hline Co & 27,17 & 15,55 & 11,04 & 18,00 \\
\hline Cs & 2,02 & 3,38 & 2,38 & - \\
\hline $\mathrm{Cu}$ & 1,02 & 4,68 & - & - \\
\hline Ga & 29,37 & 29,67 & 26,39 & 35,00 \\
\hline $\mathrm{Hf}$ & 15,28 & 17,17 & 2,54 & - \\
\hline $\mathrm{Hg}$ & 0,02 & 0,01 & - & - \\
\hline Mo & 1,01 & 0,10 & - & - \\
\hline Nb & 23,18 & 30,67 & 14,77 & 116,67 \\
\hline $\mathbf{N i}$ & 31,75 & 5,18 & 48,17 & 39,33 \\
\hline $\mathrm{Pb}$ & 16,90 & 30,47 & - & - \\
\hline $\mathbf{R b}$ & 89,80 & 138,50 & 127,74 & 124,00 \\
\hline Sb & 0,2 & 0,40 & - & - \\
\hline Sc & 30,83 & 29,83 & 73,18 & - \\
\hline Sn & 3,50 & 4,17 & - & - \\
\hline $\mathrm{Sr}$ & 101,17 & 88,17 & 107,67 & 172,00 \\
\hline $\mathrm{Ta}$ & 1,48 & 2,20 & 0,63 & - \\
\hline Th & 19,23 & 20,00 & 3,17 & - \\
\hline U & 7,55 & 13,22 & - & - \\
\hline v & 255,00 & 159,00 & 210,84 & 184,00 \\
\hline w & 5,00 & 3,95 & - & - \\
\hline$Z n$ & 82,83 & 5,60 & 21,81 & - \\
\hline $\mathrm{Zr}$ & 582,63 & 645,00 & 157,59 & 556,67 \\
\hline$Y$ & 66,77 & 66,00 & 37,62 & 126,67 \\
\hline La & 119,32 & 73,50 & 40,50 & - \\
\hline $\mathrm{Ce}$ & 177,47 & 147,83 & 77,49 & - \\
\hline $\mathrm{Pr}$ & 24,35 & 17,67 & - & - \\
\hline $\mathrm{Nd}$ & 92,90 & 70,83 & 36,79 & - \\
\hline Sm & 17,07 & 13,32 & 8,58 & - \\
\hline Eu & 3,68 & 3,22 & 2,54 & - \\
\hline Gd & 15,31 & 13,13 & 119,61 & - \\
\hline Tb & 2,26 & 2,15 & - & - \\
\hline Dy & 12,83 & 12,00 & 7,95 & - \\
\hline Ho & 2,56 & 2,42 & - & - \\
\hline $\mathrm{Er}$ & 7,03 & 6,78 & 3,58 & - \\
\hline $\mathrm{Tm}$ & 1,03 & 1,01 & - & - \\
\hline $\mathrm{Yb}$ & 6,49 & 6,23 & 2,95 & - \\
\hline Lu & 0,99 & 0,91 & 0,43 & - \\
\hline
\end{tabular}


Os resultados analíticos obtidos apresentam semelhanças com os resultados presentes na bibliografia, inclusive em elementos traços, contudo determinados valores ocorrem distintos dos apresentados na literatura. O valor médio de concentração de MgO apresenta-se superior, sendo tal variação devida à análise do filito hematítico clorítico, que possui teor de 10,1\% de MgO e baixos valores de $\mathrm{K}_{2} \mathrm{O}$. O valor superior de cálcio é decorrente da amostra Macacos II, situada nas proximidades do Povoado Macacos, que possui 3,23\% de CaO, elevando a média dos resultados. Assim, as diferenças observadas nos resultados são explicadas por variações pontuais de rochas com composição distinta do padrão.

Os valores de elementos terras raras são semelhantes nas análises, com exceção da amostra Macacos II, que revela valores elevados de elementos terras raras quando comparada com as demais análises, tanto realizadas por este trabalho, quanto disponíveis na literatura, logo representaria valores mais próximos da rocha original.

Análises em microssonda eletrônica foram realizadas em 8 amostras de filito hematítico, totalizando 113 pontos. Os valores médios de cada amostra estão presentes na Tabela 4.6, sendo que estes resultados serão melhor discutidos no próximo capítulo. Foram analisadas separadamente a matriz e os óxidos. Os resultados demonstram que os valores obtidos da matriz são semelhantes com aqueles obtidos em rocha total, porém possuem maior enriquecimento em $\mathrm{MgO}$ e, como esperado, em $\mathrm{SiO}_{2}$ e $\mathrm{Al}_{2} \mathrm{O}_{3}$. Em contra partida os óxidos exibem valores elevados de Fe e Ti. Atenção especial deve ser dada para o filito hematítico rico em clorita, que possui os valores mais elevados de Ti.

Análises de difratometria de Raios-X foram realizadas em 5 amostras do filito hematítico. Os resultados indicam ocorrência de muscovita, hematita, albita, microclínio, caolinita e gibsita. Considerados os resultados obtidos, verifica-se a preservação de porções dos feldspatos. Os resultados detalhados encontram-se em anexo. 
Tabela 4.6 - Resultados de análises em microssonda eletrônica de silicatos (tabela superior) e óxidos (tabela inferior).

\begin{tabular}{|c|c|c|c|c|c|c|c|c|c|c|c|c|c|c|c|}
\hline & $\mathrm{Na2O}$ & MgO & $\mathbf{F}$ & Al2O3 & $\mathrm{SiO2}$ & K2O & Cl & $\mathrm{CaO}$ & TiO2 & MnO & Cr2O3 & $\mathrm{FeO}$ & V2O3 & $(\mathrm{OH})$ & Total \\
\hline Brumadinho & 0,771 & 3,532 & 0,000 & 30,766 & 45,419 & 8,372 & 0,005 & 0,061 & 0,246 & 0,183 & 0,017 & 4,811 & 0,070 & 5,749 & 100,000 \\
\hline Brumadinho II & 0,723 & 3,929 & 0,054 & 22,021 & 28,249 & 3,421 & 0,104 & 0,972 & 0,626 & 0,034 & 0,075 & 3,922 & 0,052 & 35,863 & 99,999 \\
\hline Sopa & 0,328 & 0,996 & 0,000 & 37,429 & 41,378 & 7,758 & 0,015 & 0,015 & 0,276 & 0,043 & 0,015 & 2,945 & 0,023 & 8,782 & 100,000 \\
\hline Campo Sampaio & 0,141 & 3,032 & 0,000 & 26,255 & 48,068 & 10,817 & 0,022 & 0,010 & 0,801 & 0,028 & 0,026 & 5,670 & 0,036 & 5,099 & 100,000 \\
\hline Caldeirões & 0,025 & 10,781 & 0,047 & 12,755 & 56,400 & 1,350 & 0,016 & 0,022 & 0,510 & 0,135 & 0,016 & 12,058 & 0,070 & 6,507 & 100,671 \\
\hline Caldeirões II & 0,262 & 0,726 & 0,564 & 32,168 & 32,338 & 7,375 & 0,024 & 0,647 & 0,215 & 0,014 & 0,036 & 3,210 & 0,032 & 22,635 & 100,002 \\
\hline Macacos & 1,414 & 5,743 & 0,016 & 31,085 & 41,894 & 4,285 & 0,012 & 0,286 & 0,586 & 0,092 & 0,048 & 5,864 & 0,061 & 8,624 & 100,000 \\
\hline Macacos II & 1,184 & 3,974 & 0,000 & 30,598 & 42,823 & 6,178 & 0,008 & 0,149 & 0,653 & 0,051 & 0,015 & 7,091 & 0,013 & 7,265 & 100,001 \\
\hline
\end{tabular}

\begin{tabular}{|c|c|c|c|c|c|c|c|c|c|c|c|c|c|c|c|}
\hline & $\mathrm{Na2O}$ & MgO & $\mathbf{F}$ & Al2O3 & SiO2 & K2O & $\mathbf{C l}$ & $\mathrm{CaO}$ & TiO2 & MnO & Cr2O3 & $\mathrm{FeO}$ & V2O3 & $(\mathrm{OH})$ & Total \\
\hline Brumadinho & 0,021 & 0,020 & 0,350 & 0,162 & 0,157 & 0,044 & 0,014 & 0,080 & 3,057 & 0,136 & 0,040 & 88,075 & 0,095 & 7,899 & 100,0003 \\
\hline Brumadinho II & 0,014 & 0,000 & 0,296 & 0,035 & 0,111 & 0,000 & 0,004 & 0,011 & 2,394 & 0,087 & 0,020 & 92,234 & 0,053 & 4,867 & 100 \\
\hline Sopa & 0,010 & 0,096 & 0,245 & 0,153 & 0,266 & 0,042 & 0,023 & 0,014 & 18,202 & 0,097 & 0,017 & 78,697 & 0,206 & 2,314 & 100,2737 \\
\hline Caldeirões & 0,012 & 0,198 & 0,065 & 1,737 & 7,684 & 0,015 & 0,006 & 1,335 & 62,925 & 0,399 & 0,028 & 21,359 & 0,757 & 3,488 & 100,1793 \\
\hline Caldeirões II & 0,026 & 0,016 & 0,330 & 0,210 & 0,264 & 0,083 & 0,039 & 0,170 & 3,09 & 0,115 & 0,055 & 79,057 & 0,099 & 16,595 & 100 \\
\hline Campo Sampaio & 0,024 & 0,016 & 0,277 & 0,117 & 0,119 & 0,051 & 0,009 & 0,020 & 5,965 & 0,040 & 0,010 & 88,829 & 0,079 & 4,564 & 99,9995 \\
\hline Macacos II & 0,009 & 0,014 & 0,301 & 0,067 & 0,092 & 0,019 & 0,005 & 0,015 & 5,859 & 0,012 & 0,010 & 91,265 & 0,068 & 2,393 & 100,0005 \\
\hline
\end{tabular}




\section{3 - Geocronologia}

Estudo geocronológico pelo método Pb-Pb realizado por Dossin et al., 1993 forneceu idade de 1,70 Ga para o filito hematítico. Os filitos ortoderivado situados a norte, na Chapada Diamantina, foram datados por Battilani et al. (2005) e forneceram idades de $1.515 \pm 3 \mathrm{Ma}$ em muscovitas metassomáticas.

Chemale Jr. et al. (2011) dataram zircões recuperados em matriz vulcanogênica de metaconglomerados pertencentes à Formação Sopa Brumadinho e obtiveram idades de $1.192 \pm 16$ Ma. Dessa forma, os autores dividem a bacia do Espinhaço em uma sequência composta por três ciclos: a) Espinhaço Inferior (1,80 Ga a 1,68 Ga), b) Espinhaço Médio (1,60 Ga a 1,35 Ga) e c) superior (1,19 Ga a 0,91Ga). A presença do ciclo intermediário foi identificado na Chapada Diamantina por Danderfer et al. (2009), tal ciclo não foi encontrado no Espinhaço Meridional, levando Chemale Jr. et al. (2011) a acreditarem que a área comportou-se como alto estrutural ou área de não deposição. A Bacia do Espinhaço Inferior seria então representada pelas formações Bandeirinha e São João da Chapada, enquanto a superior é representada pelas formações Sopa Brumadinho, Galho do Miguel e Grupo Conselheiro Mata.

Para suportar os estudos geocronológicos desde trabalho três amostras foram selecionadas e tratadas para análise isotópica. Os zircões recuperados dos filitos hematíticos provenientes das lavras Brumadinho, Eminosa e Campo Sampaio são predominantemente secundários, assemelhando-se com padrões de rochas sedimentares. Cristais euédricos ocorrem em pequena quantidade, porém tal fato pode ser decorrente da intensa contaminação com as rochas encaixantes. Curiosamente, quanto menor a intrusão, maior a quantidade de zircões, com menor frequência de cristais euédricos. Por tal motivo, os resultados foram tratados como rochas sedimentares, de modo que a menor idade obtida representa a idade de cristalização da rocha e as idades de zircões mais antigas são consideradas como incorporadas durante o emplacement destas rochas.

As amostras foram datadas pelo método U-Pb no Laboratório de Geocronologia da Universidade de Brasília (Figuras 4.13 a 4.15), zircões datando 1.7 Ga ocorrem nas três amostras, de modo que a idade 1736 \pm 36 Ma da lavra Brumadinho representa a melhor aproximação. Tal idade não corrobora com aquelas obtidas por Chemale Jr. et al. (2011) e maiores discussões a este respeito encontram-se no próximo capítulo. 


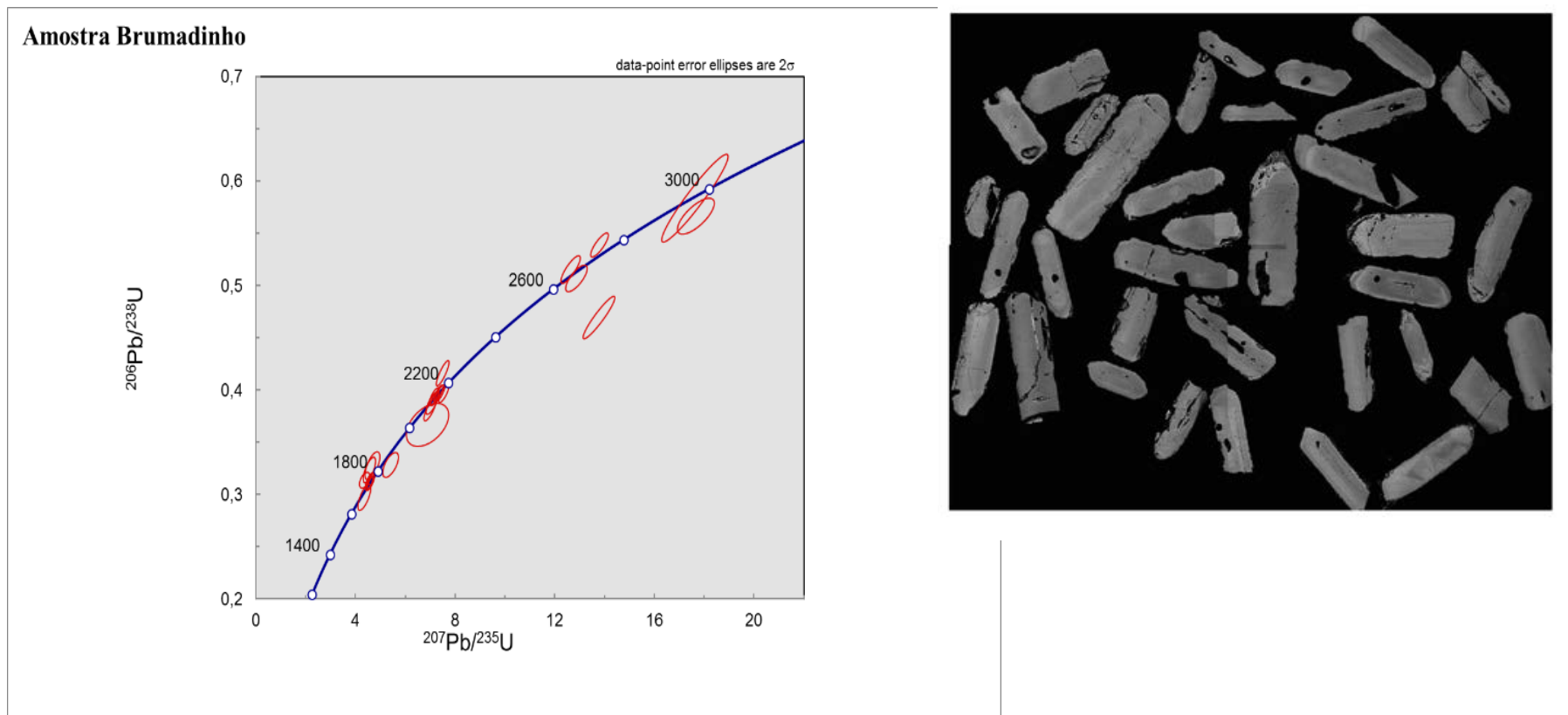

Figura 4.13 - Diagrama isotópico U-Pb de amostra de filito hematítico presente na lavra Brumadinho.

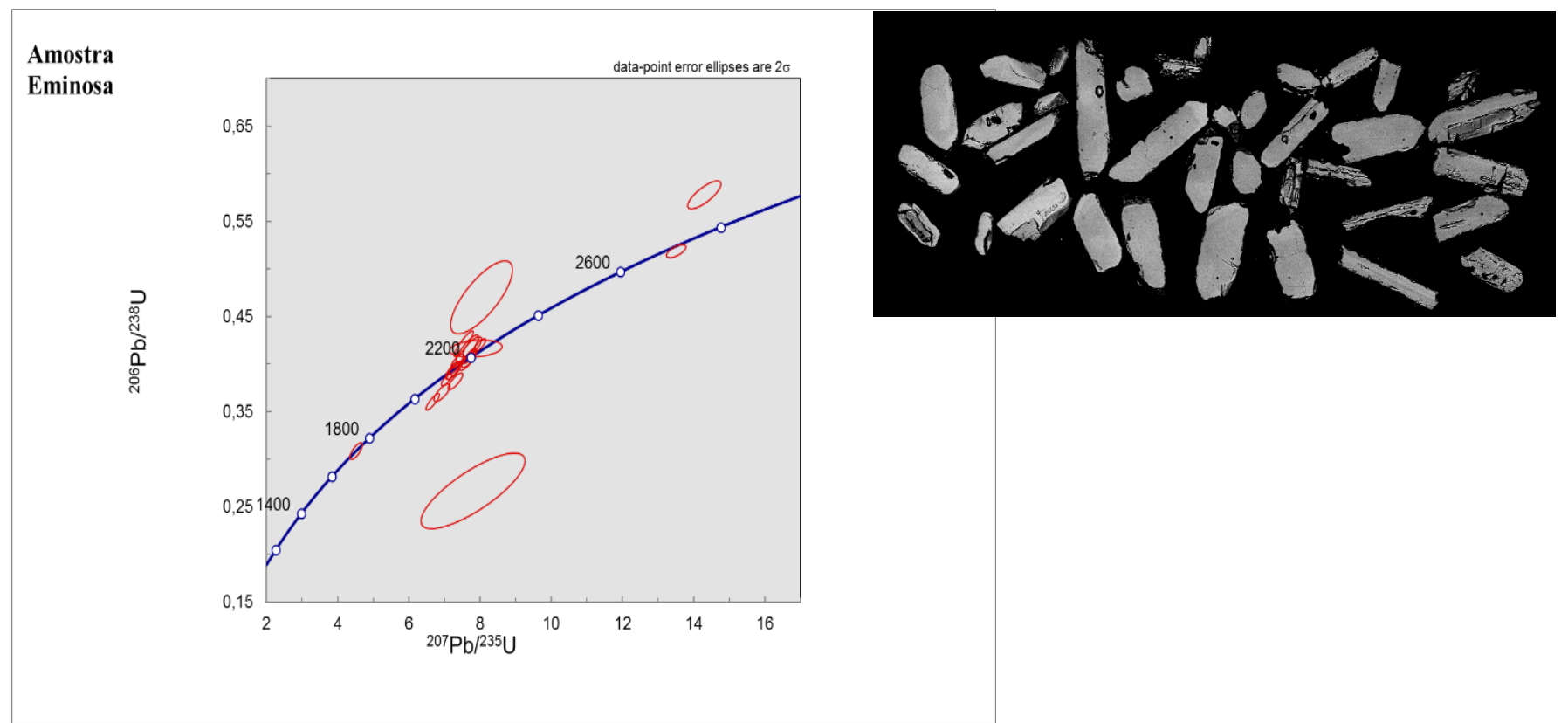

Figura 4.14 - Diagrama isotópico U-Pb de filito hematítico presente na lavra Eminosa. 


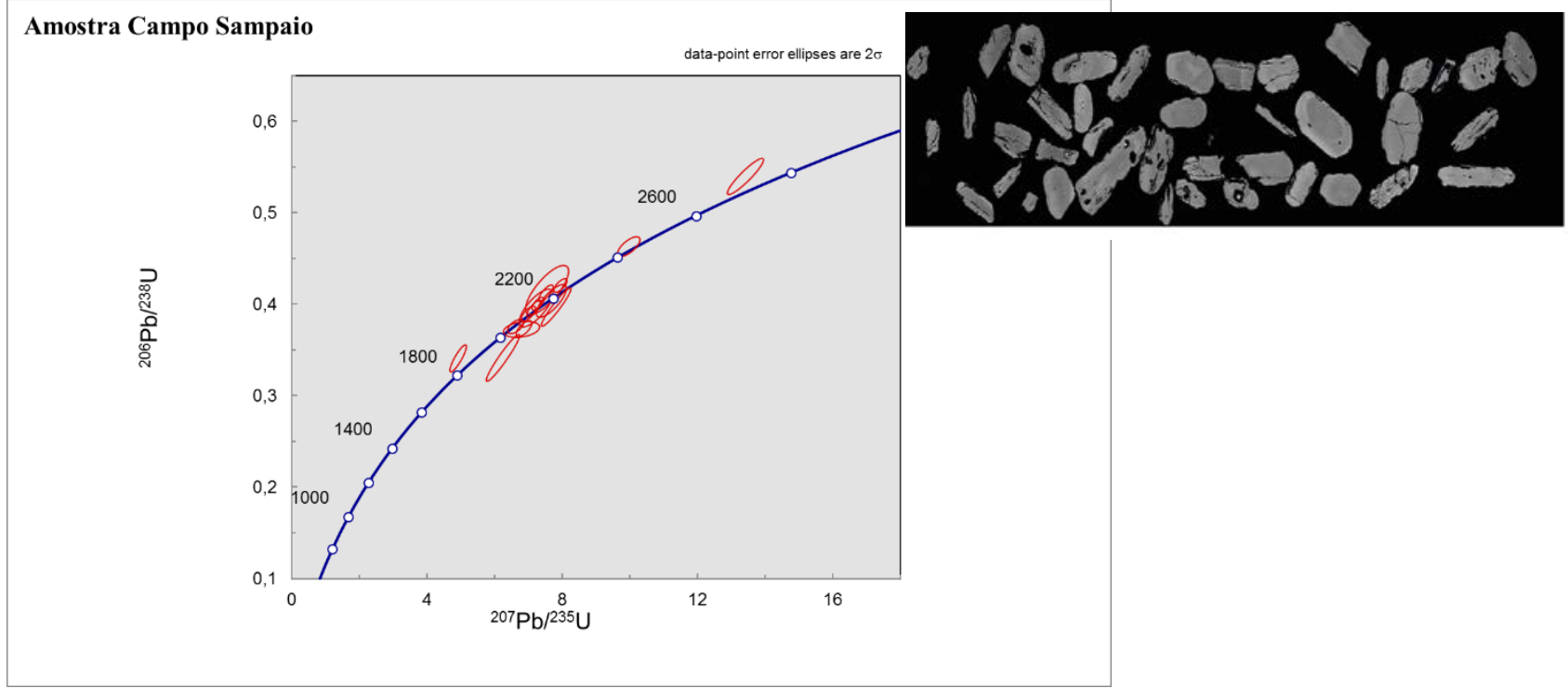

Figura 4.15 - Diagrama isotópico U-Pb do filito hematítico presente na lavra Campo Sampaio. 


\section{CAPÍTULO 5}

\section{DISCUSSÕES}

\section{1 - Discussões de Fonte: Proximal versus Distal}

A integração de todas as informações apresentadas neste trabalho permite tecer algumas observações sobre a fonte dos diamantes da região de Diamantina. Primeiramente, ao assumir que o filito hematítico seja a rocha fonte primária dos diamantes da Serra do Espinhaço Meridional, torna-se necessário um posicionamento de que a fonte seja proximal. Dentro da controvérsia existente a respeito da localização da fonte primária, se interna ou externa à bacia Espinhaço, algumas ressalvas devem ser discutidas. Caso a fonte estivesse à oeste intrudida no Cráton do São Francisco os diamantes teriam percorrido distância maior que uma centena de quilômetros, levando em consideração a quantidade de diamantes existentes, sua ampla distribuição e a tendência natural do diamante ser retido em ambiente secundário, o transporte sedimentar teria que ser extremamente eficiente. Campos \& Gonzaga (1999) mostram com estudos de caso e dados experimentais que diamantes não podem ser transportados por processos tracionais a longas distâncias, caso ocorra distribuição de diamantes em uma extensa região, torna-se necessário a existência de numerosas fontes distribuídas por toda a bacia. Aliado à isto, ao analisar os diamantes provenientes da Serra do Espinhaço Meridional, seria improvável terem percorrido tais distâncias, uma vez que não exibem sinais de transporte sedimentar.

Imaginar supostas fontes no cráton e recobertas por unidades do Supergrupo São Francisco, como proposto por Pflug (1965), Chaves et al. (1993, 1998 e 2001) e Karfunkel \& Chaves (1995), torna-se então uma tentativa de explicar a abundante ocorrência de diamantes na região e o não reconhecimento de fontes primárias. Contudo, a existência dos filitos hematíticos aliada com sua origem indefinida e os diversos relatos de que tais rochas são diamantíferas não podem ser ignorados. Desta forma, uma maneira mais concreta e coerente seria definir ou excluir os filitos hematíticos como potenciais rochas fontes de diamantes.

Uma forma de explicar a ocorrência de diamantes em todos os corpos de metaconglomerados da Formação Sopa Brumadinho, um dos argumentados defendidos a favor de fonte distal consiste na disposição das falhas normais e do magmatismo relacionado com as mesmas. As falhas normais possuem orientação geral N-S, o magmatismo precursor dos filitos hematíticos teria então ascendido aproveitando estas falhas. O transporte sedimentar foi, preferencialmente, de oeste para leste, ou seja, interceptando as falhas normais e rochas ígneas orientadas ortogonalmente. Sendo assim, durante a sedimentação da Formação Sopa Brumadinho 
ocorreu erosão destas rochas ígneas dispostas nas falhas que alimentaram assim os depósitos conglomeráticos. A ampla distribuição do filito hematítico na Formação Sopa Brumadinho pode explicar a enorme quantidade de diamantes recuperados na Serra do Espinhaço Meridional.

Outro ponto destacado consiste na baixa quilatagem e boa qualidade dos diamantes, porém, tais evidências podem ser explicadas pelas condições físico-químicas do magmatismo que transportou os diamantes do manto à superfície.

Os filitos da Serra do Espinhaço Meridional se encontram em elevado estado de alteração, tanto alteração intempérica recente, quanto metamorfismo/metassomatismo obliteram a mineralogia e geoquímica originais da rocha. Outra indagação de que a rocha fonte não esteja localizada no interior da bacia consiste na ausência de minerais indicadores de fontes kimberlíticas, tal fato pode ser explicado pelo processo de recristalização decorrente do metamorfismo regional. Este fato pode ainda ser explicado pela natureza distinta do filito hematítico, que não se enquadra como rocha kimberlítica. As campanhas de exploração de diamantes no Brasil foram por muito tempo baseadas seguindo o modelo Sul Africano, ou seja, voltadas para fontes kimberlíticas clássicas. Ao tratar-se de um lamproíto, por exemplo, os minerais indicadores são diferentes, tendo como principal mineral o espinélio. Sendo assim, a ausência de minerais indicadores kimberlíticos clássicos não desvincula a possibilidade da fonte ter caráter proximal.

\section{2- Origem dos Filitos Hematíticos: Kimberlitos versus Lamproítos}

Ao enquadrar o filito hematítico como rocha diamantífera, é mais plausível classificá-la como uma fonte clássica, ou seja, kimberlito ou lamproíto, uma vez que não há informações suficientes para propor uma rocha fonte não usual. Logo, determinadas peculiaridades permitem diferenciar a rocha como de origem kimberlítica ou lamproítica, como será discutido a seguir.

Rochas diamantíferas, em especial kimberlitos, eram definidas como rochas que ocorriam quase que invariavelmente em áreas cratônicas, até a descoberta dos lamproítos da Austrália que, assim como demais rochas diamantíferas, podem ocorrer em uma maior diversidade de ambientes geotectônicos, inclusive em faixas móveis que bordejam áreas cratonizadas.

Desta forma, ao utilizar o ambiente geotectônico como parâmetro de classificação do potencial diamantífero de determinada rocha são necessários estudos mais aprofundados das condições litosféricas, uma vez que as características em superfície nem sempre refletem as do manto. Embora o magmatismo esteja localizado em faixas móveis adjacentes às áreas cratônicas, as condições litosféricas podem ter sido favoráveis à formação e preservação do diamante, fato este que pode explicar a mineralização dos filitos hematíticos. 
Os diamantes provenientes de lamproítos apresentam tamanhos menores quando comparados aos kimberlíticos, e esta característica pode ser explicada pela forte absorção durante a evolução do magmatismo (Erlich \& Hausel, 2002). Os diamantes da Serra do Espinhaço Meridional são em sua maioria reabsorvidos e de baixa quilatagem, o que é coerente com fonte lamproítica. Outro fator relevante consiste no padrão de ocorrência das intrusões, uma vez que os corpos de filito hematítico são em sua maioria métricos, raramente formando pipes, e este padrão é mais coerente com rochas lamproíticas, que comumente ocorrem na forma de intrusões menores e diques. No que diz respeito à mineralogia e geoquímica, as sombras de cristais de feldspatos encontrados nos filito hematíticos poderiam ser sanidina, mineral típico de rochas lamproíticas, assim como a presença marcante de titânio é característico de lamproítos.

Scott Smith (1996) afirma que em lamproítos diamantíferos a fase piroclástica apresenta maior mineralização em diamantes, uma vez que possui resfriamento em menor tempo, já a fase magmática permanece em altas temperaturas por períodos maiores. Tal fato explica a provável maior mineralização nas metabrechas quartzíticas, uma vez que constituem alvo mais recorrente de atividade garimpeira.

Com base nas informações acumuladas, a rocha original do filito hematítico não se enquadraria como kimberlito por algumas razões, como o padrão de ocorrência, a ausência de minerais satélites clássicos e a presença de pseudomorfos de feldspato. Desta maneira, o magma que originou os filitos hematíticos possui características que o enquadra de forma mais coerente como magma de afinidade lamproítica, sendo o filito hematítico, portanto, classificado como possível metalamproíto.

\section{3 - Características dos Diamantes da Serra do Espinhaço Meridional}

Em relação às feições presentes nos diamantes da Serra do Espinhaço Meridional, garimpeiros experientes da região relatam que a maioria dos cristais é de baixa quilatagem, porém de boa qualidade, fato este que leva parte dos garimpeiros a descartar o material grosso, com possibilidade de conter diamantes. Outra característica consiste na coloração, uma vez que são geralmente incolores acompanhados de spots verdes em sua superfície, gerando uma tonalidade esverdeada, entretanto, esta característica somente evidencia que o diamante ficou em contato com minerais radioativos. Os filitos hematíticos possuem elevada quantidade de zircão, o que pode explicar a abundância destes spots verdes, que são facilmente removidos durante o processo de lapidação. 
A título de comparação, características peculiares podem ser diagnósticas em determinadas províncias ou distritos diamantíferos, como os diamantes de Coromandel que são conhecidos pelo seu "gigantismo", os diamantes da Chapada Diamantina conhecidos por possuir os famosos policristalinos carbonados, enquanto, que os diamantes de Diamantina e adjacências possuem como peculiaridade cristais de baixa quilatagem e boa qualidade. Tal característica pode explicar o fato da menor ocorrência de fragmentos, uma vez que cristais maiores são mais suscetíveis à quebras, além do fato de que lascas e fragmentos de diamantes pequenos são mais difíceis de serem recuperados. O tamanho reduzido dos diamantes pode ainda ser explicado pelas condições do magmatismo, em que magmas lamproíticos proporcionam reabsorção mais efetiva, seguindo o mesmo raciocínio, fragmentos e lascas podem ter sido totalmente reabsorvidos. Entretanto, tal fato não explicaria, caso exista, a sistemática baixa quilatagem em diamantes octaédricos, ou seja, sem reabsorção, sendo necessário um estudo morfológico mais detalhado das populações. A atual situação de extinção da atividade garimpeira dificulta estudos precisos dos diamantes.

Segundo Filemon (2005) a maioria dos diamantes estudados de Diamantina possui baixa taxa de agregação de nitrogênio, o que sugere menor tempo ou temperatura de residência mantélica. O fato de possuir menor temperatura, ou seja, ser derivado de porções superiores do manto é característico de kimberlitos tipo II, que por sua vez são semelhantes aos lamproítos.

Os garimpeiros utilizam técnicas empíricas para rastrear as potenciais áreas mineralizadas. Desta forma, em ambiente aluvionar o diamante ocorre normalmente associado com demais minerais pesados, pois devido à elevada densidade se concentram de forma semelhante. Por não haver registro da ocorrência dos minerais satélites clássicos utilizados para rastrear o diamante, o uso de outros minerais pesados torna-se uma ferramenta importante na localização de áreas mineralizadas. Outra técnica utilizada para determinar potenciais áreas diamantíferas, neste caso levando em consideração a lavra em metaconglomerados/metabrechas, consiste na presença do filito hematítico que, segundo os garimpeiros locais, é um dos condicionantes para que as unidades adjacentes sejam diamantíferas, fato este que corrobora seu carácter de fonte primária.

Em visita à lavra Caldeirões foram cedidos três diamantes por garimpeiro local, inclusive indicando o local exato que forneceu os cristais (Figura 5.1). O processo de lavra é artesanal e consiste no desmonte hidráulico do material que posteriormente passa por grelhas que então aprisionam o diamante (Figura 2.2). Foi relatado que é necessário tratar grande volume para recuperar diamantes, uma vez que o material é quase inteiramente argiloso. 


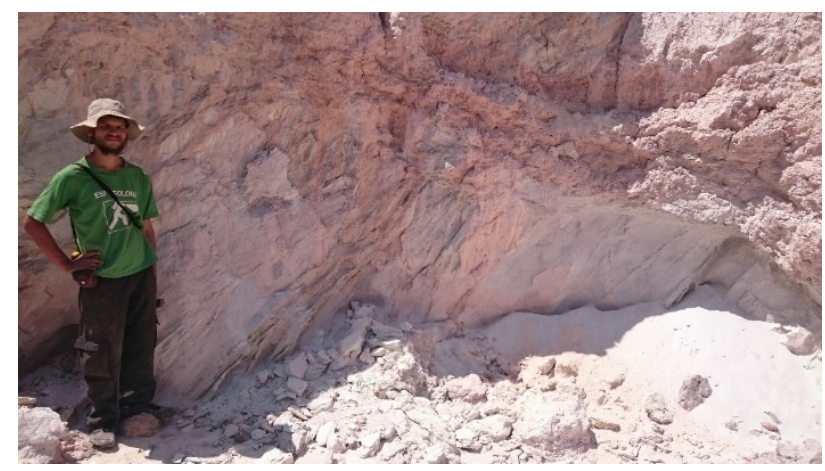

Figura 5.1 - Local de lavra em que diamantes foram recuperados.

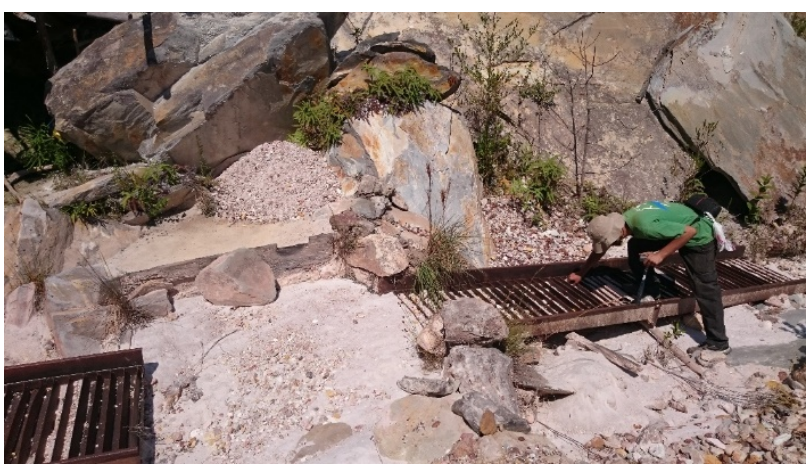

Figura 5.2 - Bica de sluicer utilizada na recuperação dos diamantes.

Apesar de não constituir quantidade representativa para levantamento estatístico, os três diamantes apresentam o mesmo padrão de feições e texturas, tidos como típicos da região (Figuras 5.3 a 5.8). Todos os diamantes possuem hábito tetrahexaedroide (máxima reabsorção), não apresentando faces reliquiares octaédricas. Os diamantes são incolores com spots verdes em sua superfície, e a textura shagreen, típica de cristais reabsorvidos, é proeminente e abundante. Marcas de percussão (marcas em unha) ocorrem nos três cristais, tais marcas de impacto não estão necessariamente relacionadas com transporte sedimentar, mas sim com o emplacement da rocha, quando o diamante é submetido à impactos com fragmentos da encaixante e xenólitos. Não há evidências de feições de transporte sedimentar, caracterizadas por abrasão em suas arestas. Neste ponto é importante diferenciar o arredondamento que ocorre pelo processo de reabsorção durante a ascensão do magma, este responsável pelo abaulamento do cristal e considerável redução de massa, do processo de abrasão que ocorre em ambiente sedimentar. Sendo assim, o grau de arredondamento do cristal não significa maior transporte, sendo o transporte sedimentar representado pela abrasão em suas arestas, o que não ocorre nos diamantes analisados.

À propósito de comparação, as Figuras 5.9 e 5.10 ilustram exemplos de diamantes, de áreas distintas, com abrasão em suas arestas, representando típicos diamantes que percorreram maiores distâncias em ambientes secundários. 

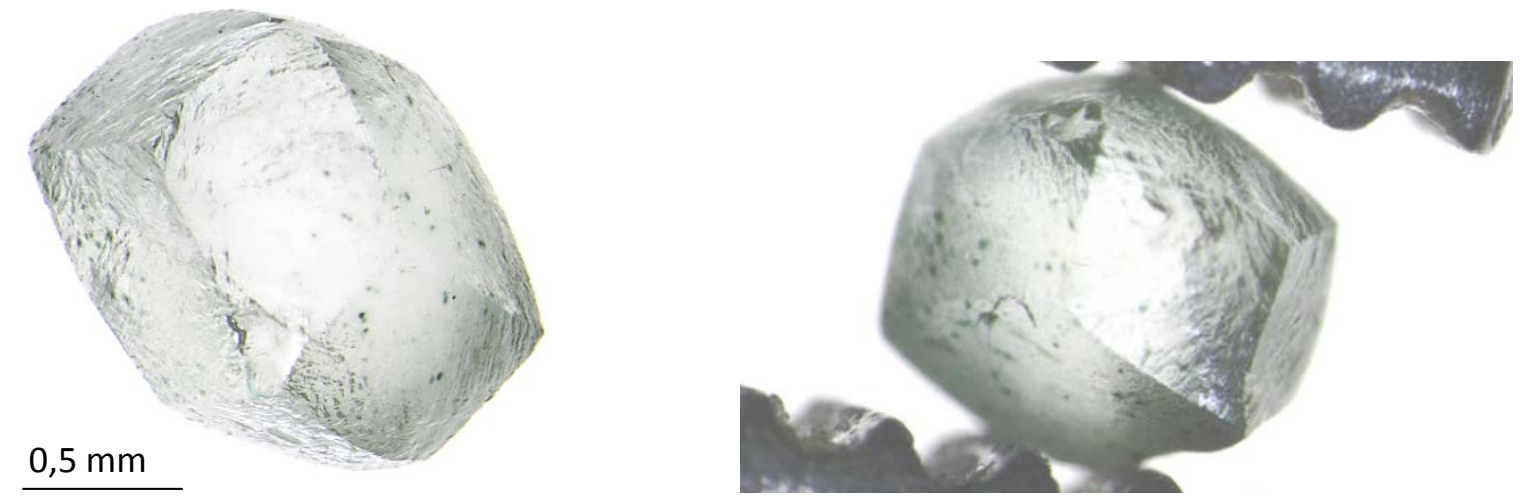

Figuras 5.3 e 5.4 - Detalhes diamante 01 com arestas sem sinais de abrasão.
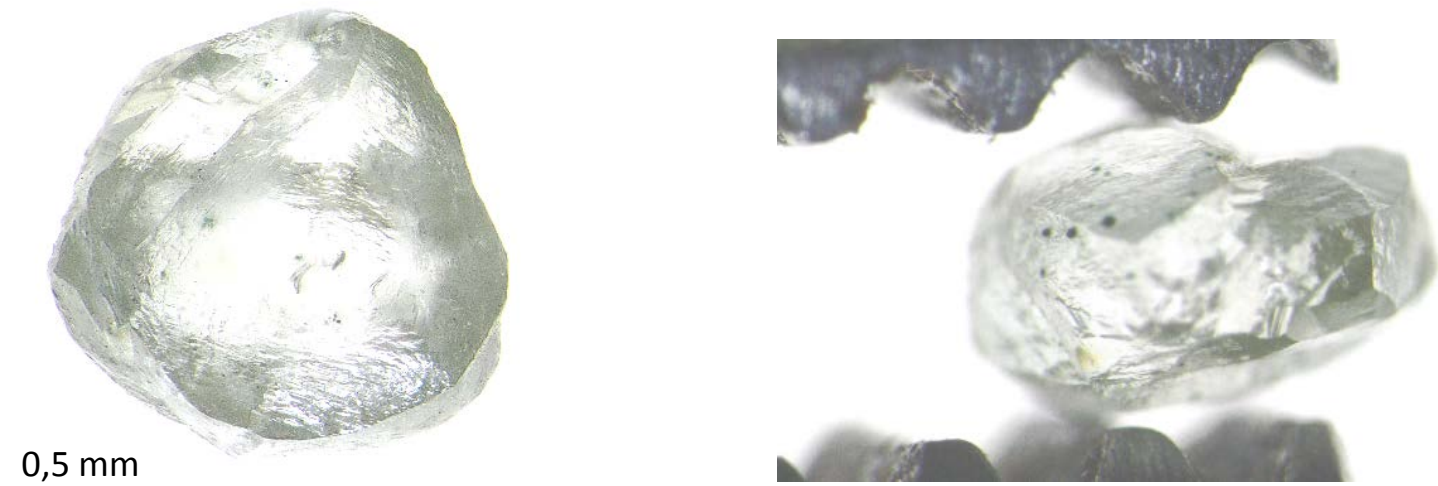

Figuras 5.5 e 5.6 - Detalhes diamante 02, tetrahexaedróide achatado.
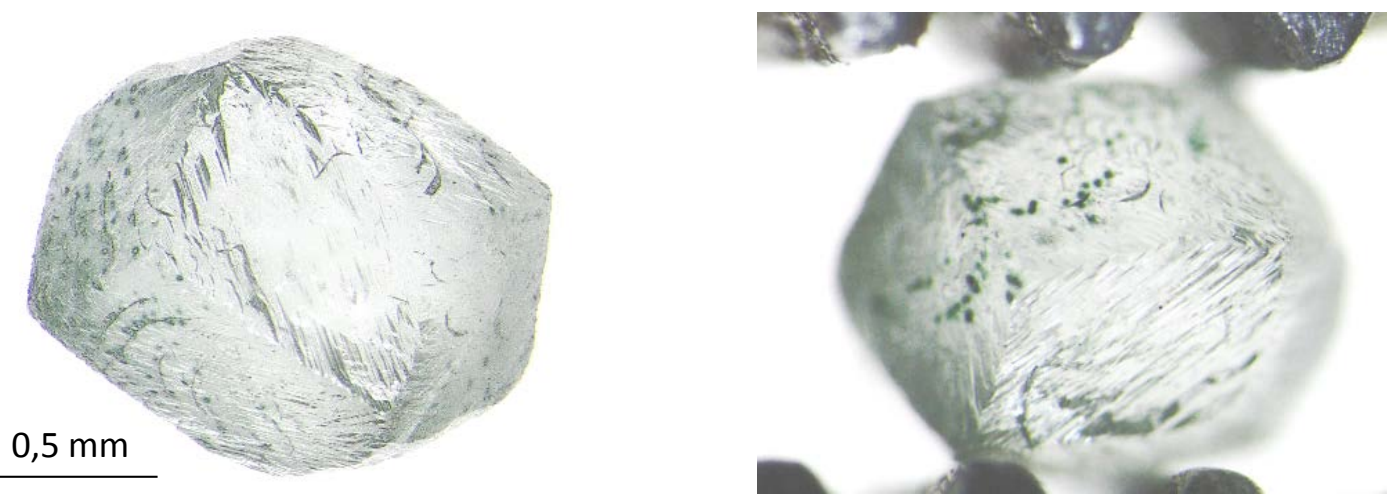

Figuras 5.7 e 5.8 - Detalhes diamante 03, com marcas de percussão e spots verdes.
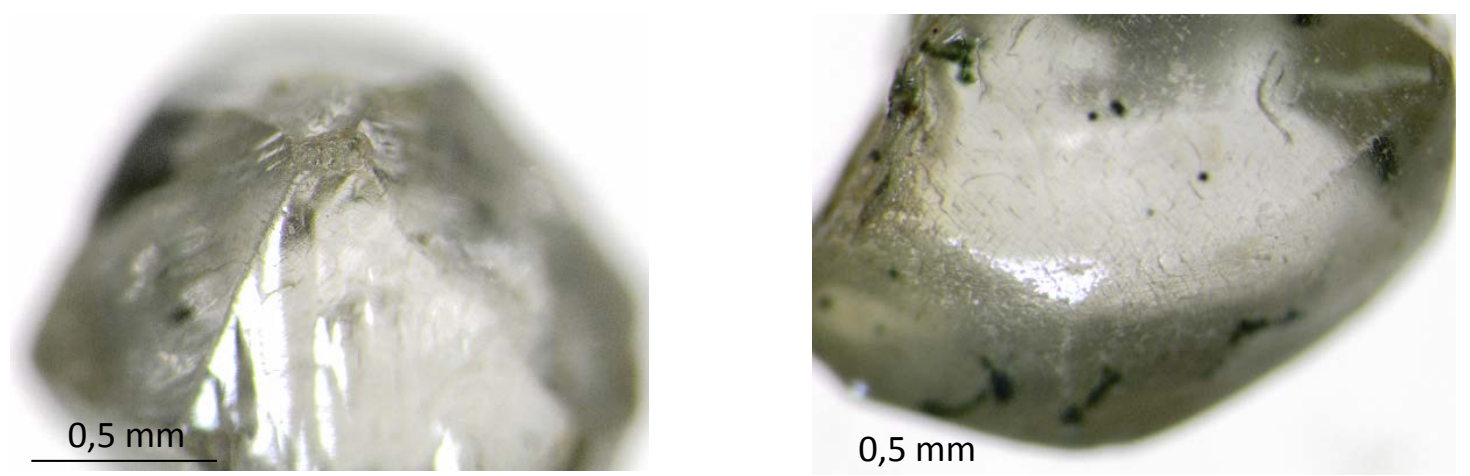

Figuras 5.9 e 5.10 - Detalhes de exemplos de diamante com feições de transporte sedimentar (marcas de percussão). 
Chaves et al. (1998) afirmam que não existem diferenças entre as populações de diamantes de acordo com área de origem, ou seja, não há como definir sua proveniência a partir de feições morfológicas, uma vez que determinadas feições (spots) encontram-se inerentes à porção externa do cristal. Já de acordo com Almeida Abreu (1996) assim como garimpeiros da região os diamantes apresentam feições particulares de acordo com o campo diamantífero de origem, o que sugere fonte proximal.

No presente trabalho não foi foco comprovar a existência de feições típicas para cada região estudada de acordo com a origem do diamante. Por outro lado, conversas informais mantidas com os garimpeiros da região, estes nos asseguram que determinados locais fornecem diamantes com características próprias e bem distintas, sobretudo os diamantes provenientes da lavra Campo Sampaio

\section{4 - Relação Entre Filitos Hematíticos e Fonte dos Diamantes}

A partir dos dados apresentados, claramente há uma relação direta entre os filitos hematíticos e a ocorrência de diamantes na Serra do Espinhaço Meridional. Diversas são as evidências, registros e relatos de atividade garimpeira que resultaram na recuperação de diamantes provenientes diretamente desta rocha.

Em conversa com garimpeiros locais diversos questionamentos foram efetuados, dentre tais questionamentos destaca-se qual a relação existente entre o "giz” (filito hematítico) e a ocorrência de diamantes. Na maioria dos casos foi relatado que não há diamante no giz, porém o giz “atrai” o diamante, uma vez que onde ocorre o giz é maior a probabilidade do local fornecer diamantes. Ou seja, garimpeiros em sua maioria ignoram a existência de diamantes no filito hematítico, porém o utilizam como indicador de que o material próximo seja diamantífero. Em contrapartida, há garimpeiros que lavram e relatam a ocorrência de diamante no filito hematítico, porém em baixo teor.

Em resumo, na região de Diamantina o diamante ocorre basicamente em cinco tipos de depósitos:

1- Nos metaconglomerados, sendo a forma de ocorrência mais difundida, com afloramentos consagrados na área de Sopa-Guinda. As porções mais friáveis foram lavradas manualmente ou com auxílio de máquinas, as porções mais coesas ou “massa gelada”, nome dado pelos garimpeiros, permanecem in situ. 
2- Na metabrecha quartzítica, tais rochas afloram preferencialmente como material friável e associado com o filito hematítico, recebe a mesma denominação dos metaconglomerados, ambos denominados de “massa”.

3- No filito hematítico, embora em menor ocorrência, observa-se atividade de lavra sobre o filito, principalmente quando friável.

4- Em lateritas e colúvios, são chamados de "gorgulho” ou "canga” pelos garimpeiros. Localmente formam espessas camadas de material lavrado. Ocorrem como alteração do filito hematítico ou metaconglomerado.

5- Em aluviões, grande parte das drenagens possui contribuição de alguma rocha anteriormente citada, logo há possibilidade de ocorrência de diamantes, desde pequenos córregos até o Rio Jequitinhonha.

Estudos realizados por Moraes (1934) na lavra Perpétua descrevem o filito hematítico sendo lavrado para recuperação de diamantes, onde os garimpeiros se referiam ao filito hematítico como “moafa” ou “pedra de sabão”. O autor lavrou 30 metros cúbicos do filito, sendo 10 metros de rocha alterada e coloração esbranquiçada e 20 metros cúbicos do filito cinza. Deste último material tratado foram recuperados diamantes, porém havia relatos de que o primeiro também era diamantífero. Tais estudos são importantes, pois registram períodos em que havia intensa atividade de lavra, o que facilita a exposição e a identificação das unidades lavradas assim como de seu potencial diamantífero.

Também é descrita a ocorrência de diversos rasgões e escavações sobre os filitos hematíticos, vestígios que são observados até hoje, embora o material a ser tratado tenha alternado, perdendo o foco de lavras sobre os filitos e migrando para metaconglomerados/metabrechas, provavelmente devido ao maior teor e facilidade de lavra.

Dentre as escavações sobre os filitos hematíticos, destacam-se as lavras Caldeirões (Figura 5.11) e Barro (Figura 5.12). Em sua maioria são depressões retangulares originadas a partir da retirada de material de alteração do filito hematítico e encontram-se marginais às lavras. 


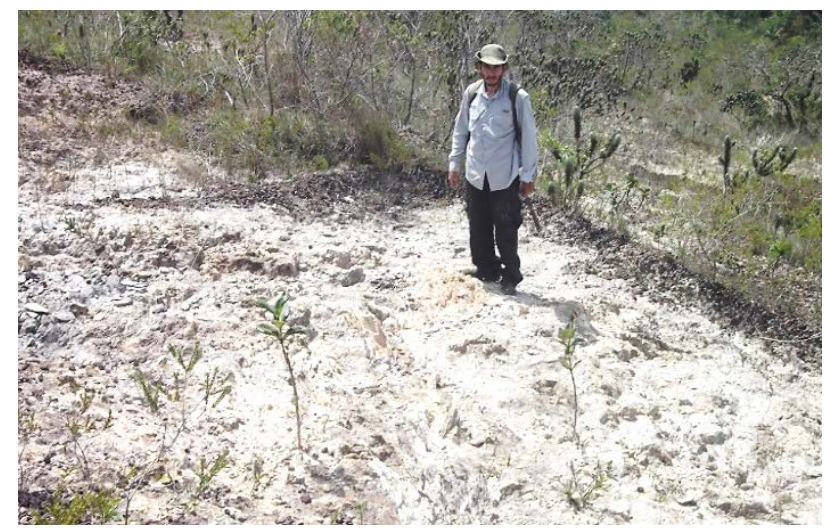

Figura 5.11 - Local de atividade garimpeira sobre o filito hematítico na lavra Caldeirões.

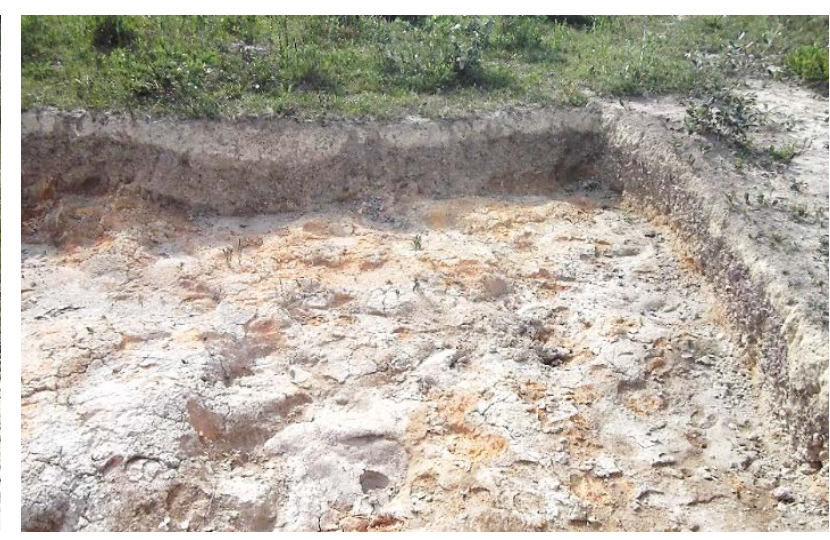

Figura 5.12 - Atividade garimpeira sobre o filito hematítico na lavra Barro.

Atividade garimpeira recente ocorre na porção superior da lavra Brumadinho (Figura 5.13), ao contactar o garimpeiro responsável pelo tratamento do material, o mesmo informou que foram lavrados o referente à dois caminhões de filito hematítico com o intuito de verificar a possível mineralização da rocha, como resultado foi recuperado um "punhado” de diamantes finos. Ou seja, embora seja mineralizado, o filito hematítico não apresentou condições para tornar-se economicamente viável à nível de lavra garimpeira.

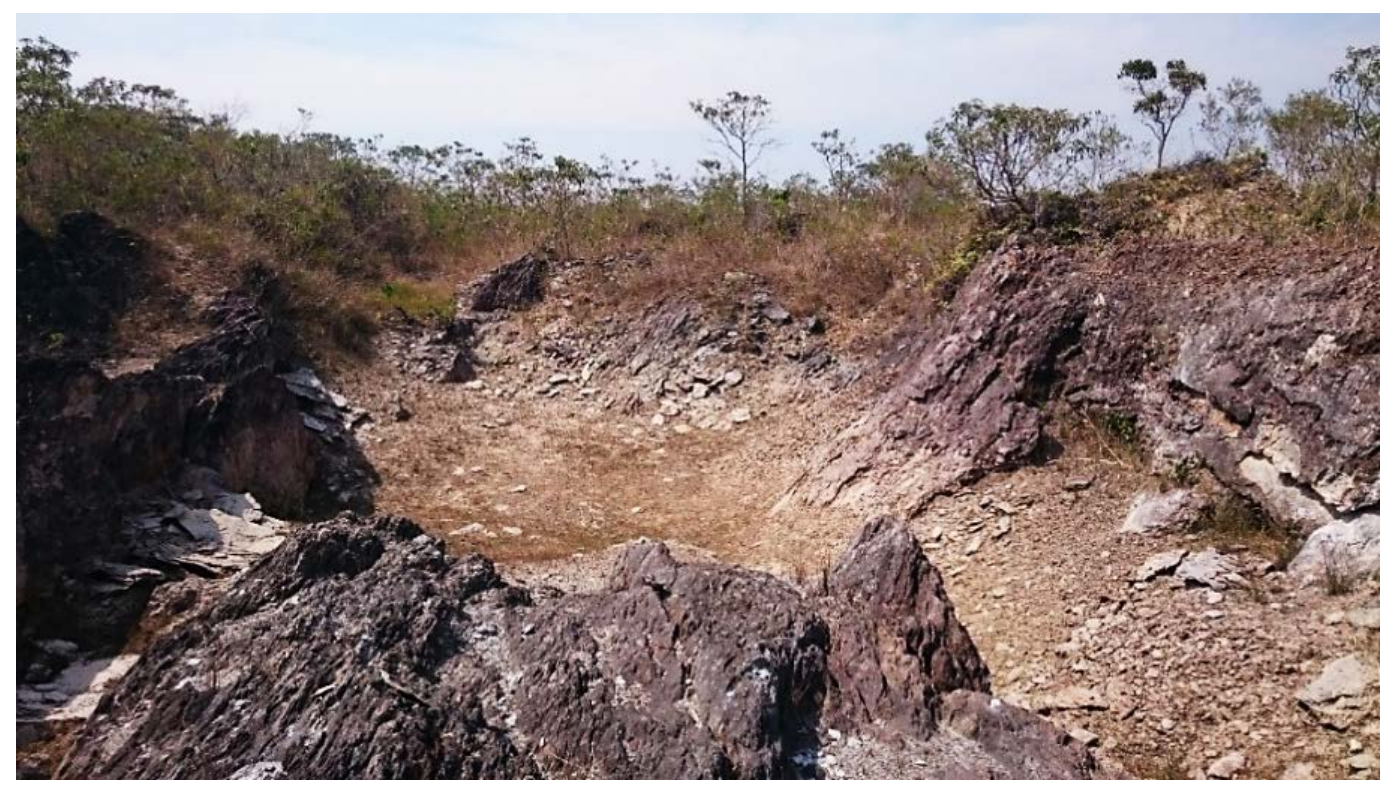

Figura 5.13 - Local de atividade garimpeira sobre o filito hematítico na Lavra Brumadinho.

Analisando as particularidades das rochas diamantíferas, existe uma relação direta entre o filito hematítico, metabrecha quartzítica, metaconglomerado, gorgulho e o diamante. As falhas de borda do rifte responsáveis pela paleogeografia ao longo da qual os leques aluviais e rios entrelaçados se desenvolveram podem ter sido responsáveis pela formação dos condutos pelos quais o magmatismo lamproítico ascendeu de forma rápida até as porções rasas da crosta. 
O filito hematítico aflora em todas as lavras visitadas, e como já relatado, encontra-se preferencialmente à oeste dos metaconglomerados. Uma vez que o aporte sedimentar foi de oeste para leste, o filito hematítico mineralizou os metaconglomerados, o que pode também ser corroborado pela ocorrência de fragmentos angulosos do filito hematítico no arcabouço dos metaconglomerados. Os depósitos conglomeráticos serviram então como armadilhas sedimentares e concentraram os diamantes, o que explica seu teor elevado em relação à rocha fonte. Além de alimentar os conglomerados, magmatismo de rochas lamproíticas geram depressões, tais depressões possivelmente alteraram a paisagem e redirecionaram o transporte de drenagens, o que pode ter favorecido a formação dos leques aluviais e rios entrelaçados responsáveis pela deposição dos depósitos conglomeráticos.

Em campo percebe-se que a metabrecha quartzítica possui gênese diretamente relacionada com o filito hematítico, interpretada desta forma como resultado da interação do magmatismo explosivo com sedimentos bacinais ainda não litificados. Ao imaginar o ambiente úmido com presença de lagos, houve ampliação de atividade freatomagmática durante a ascensão do magmatismo. A metabrecha quartzítica, por ser resultado desta interação, apresenta maior porosidade quando comparada com o filito hematítico, logo este fator facilitou a percolação de fluídos e consequente alteração, o que explica a ocorrência predominante friável desta rocha, inclusive dos fragmentos de quartzito. O filito adjacente à metabrecha também foi exposto à percolação dos fluídos, logo se encontra friável, de modo que as duas rochas assemelham-se visualmente.

O “gorgulho”, crostas lateríticas diamantíferas, é formado a partir do filito hematítico. Em diversos locais observa-se que o material lavrado possui somente filito hematítico como substrato e material parental. A ocorrência do material laterítico em áreas planas elevadas com ausência de drenagens nas adjacências descarta origem alóctone do gorgulho. Devido à redução de volume durante o processo pedogenético, o esperado é que o gorgulho possua teor superior ao filito hematítico, tal fato aliado com ocorrência da crosta como fragmentos desagregados, o que facilita a lavra, explica a maior atividade garimpeira sobre o gorgulho.

Na lavra situada no Povoado de Macacos, o filito hematítico se faz presente, contudo não há registros de metaconglomerados/metabrechas quartzíticas, sugerindo que o condicionante para que ocorra o diamante não consiste na presença exclusiva de metaconglomerado-metabrecha, mais uma vez reforçando o potencial diamantífero do filito hematítico.

Assim, ao analisar todas as informações obtidas durante a realização deste trabalho e aqui apresentadas, o fato do filito hematítico ser a potencial rocha fonte dos diamantes explica a 
ocorrência do diamante em todas as unidades diamantíferas da Serra do Espinhaço Meridional: metabrecha quartzítica, metaconglomerado, gorgulho e depósitos aluvionares (Figura 5.14 e 5.15).

Em relação à geoquímica dos filitos hematíticos, os mesmos foram submetidos à forte tectonismo e baixo metamorfismo, deformando sua geometria e alterando a composição química/mineralógica, de modo que o resultado são rochas metamórficas estiradas com química de rocha compatível à classe ultrabásica alcalina.

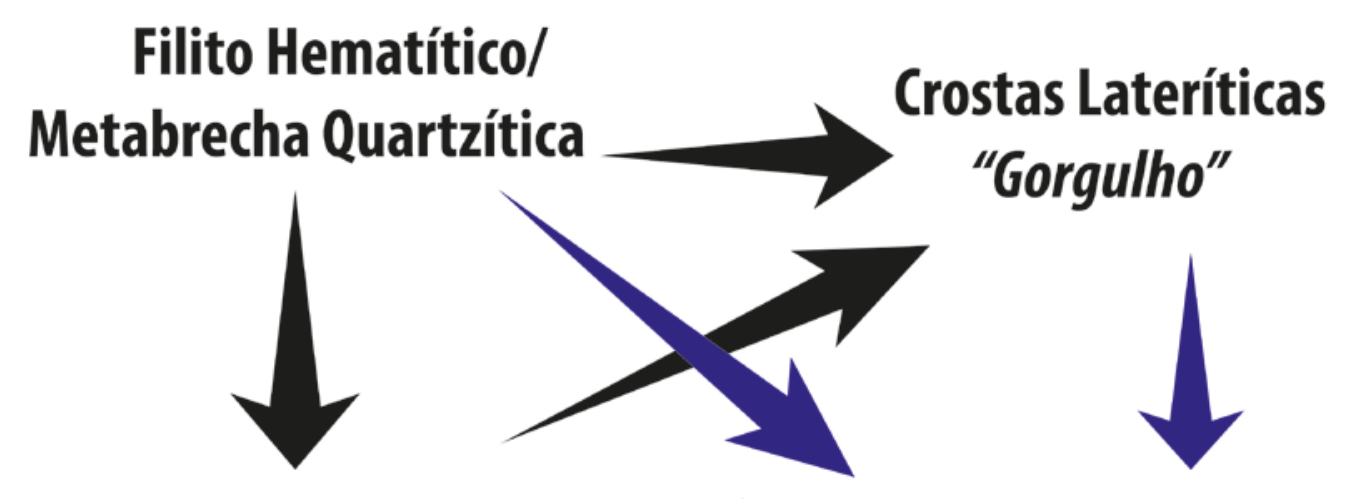

\section{Metaconglomerado}

Ambiente Aluvionar

Figura 5.14 - Ilustração esquemática explicando o ciclo do diamante na região da Serra do Espinhaço Meridional.

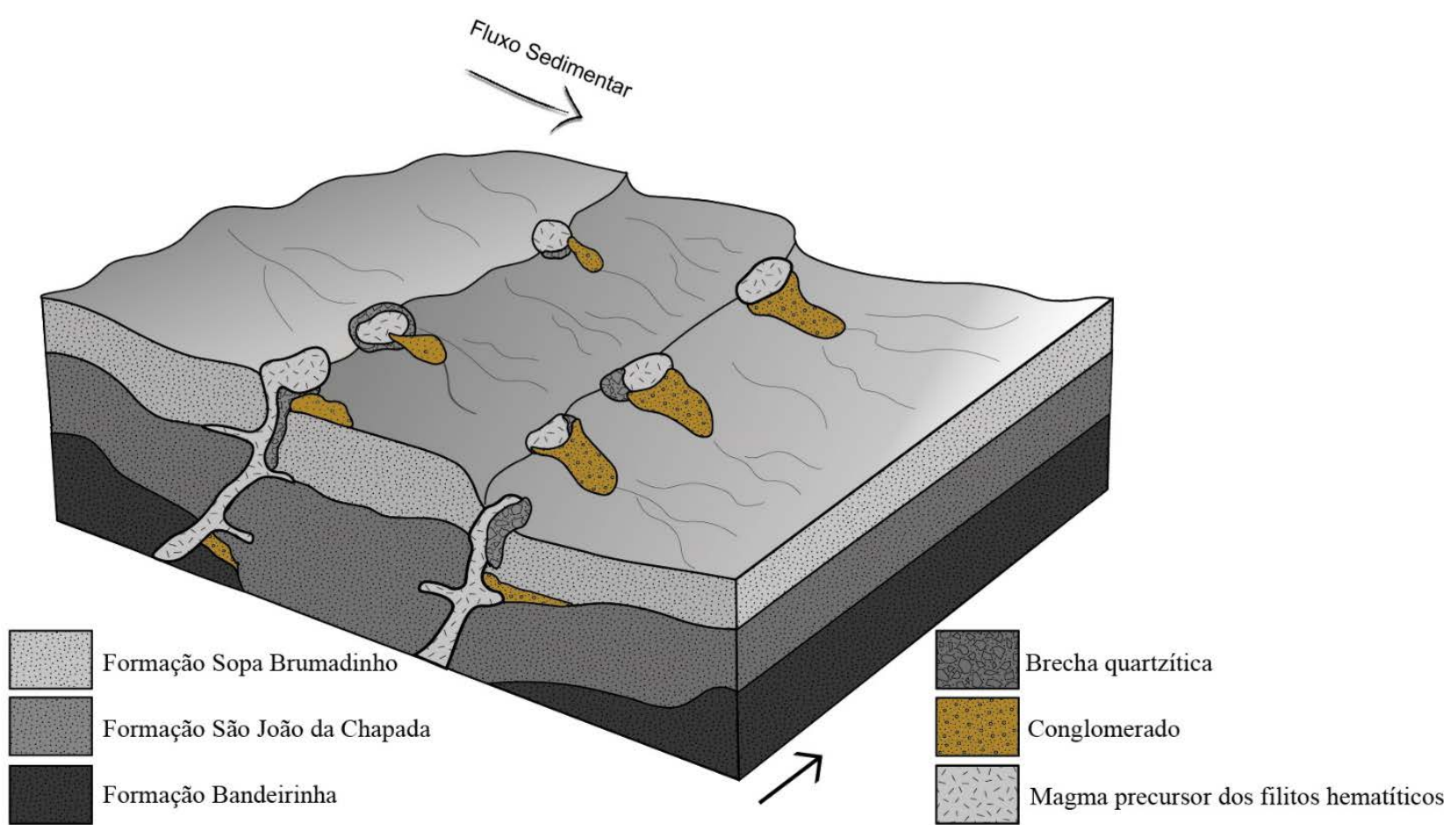

Figura 5.15 - Modelo ilustrando intrusão dos corpos correspondentes ao filito hematítico e relação com a metabrecha e metaconglomerado. 
A elevada concentração de potássio pode ser decorrente da natureza potássica da rocha aliada ao enriquecimento a partir de processos metassomáticos, uma vez que zonas de falha são favoráveis para a percolação de fluídos. A formação de paleossolos pode ter ocorrido localmente, contudo aceitar que a pedogênese tenha atuado em todas as ocorrências, visto o intenso processo erosivo e a geoquímica da rocha, torna-se improvável que tal processo explique a anomalia dos resultados.

As análises geoquímicas evidenciam homogeneidade dos resultados, contudo algumas ressalvas merecem destaque. O filito hematítico verde rico em clorita presente na lavra Caldeirões apresenta valores elevados de MgO (10,10\%), decorrente da abundância de clorita. O filito hematítico que ocorre no acesso ao povoado de Macacos, referente à amostra Macacos II, apresenta valores reduzidos de silício (31,36\%) e elevados de cálcio (3,23\%), titânio (5,23\%) e fósforo (2,43\%), embora possua o mesmo padrão de elementos terras raras, os resultados também evidenciam valores superiores às demais amostras. Logo, é possível que filitos hematíticos localizados em domínios pertencentes à Formação São João da Chapada forneçam resultados que melhor representem a rocha original.

As análises de microssonda na matriz de silicatos revela a presença de dois grupos principais de minerais. O primeiro grupo apresenta valores superiores de sódio, magnésio e cálcio acompanhado de valores reduzidos de potássio. O segundo grupo de minerais apresenta valores elevados de potássio, aproximadamente 10\%, e valores reduzidos em sódio, magnésio e cálcio. Possivelmente a matriz original da rocha era composta por minerais que seguem tal composição. A presença de richeterita titanínera, anfibólio sódico-cálcico rico em magnésio típico de rochas lamproíticas, e flogopita são condizentes com a composição do primeiro grupo de minerais. Demais minerais potássicos podem ser relacionados com o segundo grupo, atualmente presentes na forma de fengita mas resultado da alteração de feldspato potássico e leucita.

As análises em óxidos evidenciam altos valores em ferro e titânio. Minerais tais como rutilo, titano hematita, ilmenita e possível titanita podem ser identificados nos resultados. Lamproítos apresentam valores extremos de titânio, uma vez que as rochas possuem uma série de minerais titaníferos. Flúor também é encontrado preferencialmente nos óxidos.

Em relação aos resultados geocronológicos, admitindo que os filitos sejam sinsedimentares aos metaconglomerados, ambos deveriam fornecer idades semelhantes. Deste modo, torna-se necessário maior quantidade de datações do filito hematítico assim como priorizar amostragens no centro dos corpos de maior dimensão, onde teoricamente existe menor interação 
com as rochas encaixantes e com os processos superimpostos (contaminação durante o emplacement da intrusão, metamorfismo e demais processos).

Aliado ao maior refinamento das datações dos filitos hematíticos, é necessário também maior quantidade de análises dos metaconglomerados, uma vez que tais idades devem ser recorrentes em rochas distribuídas por toda a Formação Sopa Brumadinho. Somente com mais resultados será possível determinar com maior precisão a idade de cristalização do filito hematítico e consequentemente, de deposição das unidades sedimentares. 


\section{CAPÍTULO 7}

\section{CONCLUSÕES E RECOMENDAÇÕES}

Os filitos hematíticos representam rochas ígneas de natureza exótica. Os principais argumentos que suportam a natureza magmática destas rochas são:

- As relações de discordância claramente identificadas no campo em relação ao acamamento das rochas encaixantes (o que pode ser observado em diferentes lavras visitadas);

- A composição química dos filitos hematíticos ainda guarda semelhanças aquelas encontradas em magmas lamproíticos. As principais diferenças podem ser atribuídas aos processos superimpostos de metamorfismo e intemperismo;

- Presença comum de pseudomorfos prismáticos, interpretados como fenocristais de feldspato potássico (ortoclásio ou sanidina) transformados em massa de mica branca (sericita ou muscovita);

- Presença reliquiar de textura brechoidal com matriz e fragmentos de rochas muito similares a corpos de rochas alcalinas recentes;

- Similaridades petrográficas com rochas estudadas na região da Chapada Diamantina, no estado da Bahia, as quais preservam texturas ígneas.

Além de rochas ígneas, os filitos hematíticos possuem todos os condicionantes necessários para ser a fonte primária dos diamantes da Serra do Espinhaço Meridional, podendo ser interpretados como possíveis metalamproítos. Entre as principais evidências que corroboram o filito hematítico como fonte primária há o fato de:

- Sempre ocorrerem associados com os metaconglomerados e metabrechas quartzíticas, e que em todos os garimpos visitados o filito hematítico aflora nas adjacências, preferencialmente à oeste;

- Existirem relatos na bibliografia e por garimpeiros locais de recuperação de diamantes a partir do filito hematítico, por exemplo a lavra sobre corpo intrusivo (filito hematítico) que ocorre na lavra Brumadinho, que produziu dezenas de diamantes finos de baixo valor venal (comunic. oral do garimpeiro Sr. Tião). É importante ressaltar que nas demais lavras foram identificadas estas mesmas rochas como alvo recorrente de atividade garimpeira;

- O gorgulho, material laterítico proveniente de processos de lateritização sobre o filito hematítico, ser diamantífero;

- O diamante da lavra Caldeirões, em material associado ao filito hematítico e metabrecha quartzítica, não apresentar sinais de transporte, concordando com fonte proximal; 
- Fragmentos de filito hematítico em metaconglomerados são visivelmente angulosos em comparação com demais clastos (seixos, blocos e calhaus), sugerindo fonte proximal dos fragmentos e potencialmente dos diamantes;

- Diamantes também ocorrerem no Povoado Macacos, sendo recuperados diretamente do filito hematítico sem associação com metaconglomerado ou metabrecha quartzítica.

Desta forma, com todas as evidências listadas acima, o presente estudo sugere que os filitos hematíticos são de fato rochas de afinidade lamproítica, fonte primária dos diamantes da região de Diamantina, estado de Minas Gerais.

Os filitos hematíticos estudados apresentam composição geoquímica média semelhante quando comparados com os resultados presentes na bibliografia. Entretanto, localmente ocorrem rochas com maior enriquecimento em magnésio, cálcio e outros elementos indicando se tratar de heterogeneidades do magma (comum nestes tipos de rochas) ou porções mais preservadas da deformação e mudanças metamórficas/metassomáticas. De qualquer modo os valores elevados de titânio se destacam como um elemento comum e em concordância com os magmas lamproíticos de ambientes modernos.

Desta maneira, torna-se necessário um mapeamento detalhado dos corpos de filito hematítico assim como amostragens de grande volume para determinar o teor médio de diamantes. A região da lavra Caldeirões consiste em uma intrusão de grande porte, sendo que tal local merece destaque ao se analisar a possibilidade de se extrair diamantes diretamente do filito, uma vez que a rocha ocorre predominantemente como pequenos diques. As ocorrências da região de Macacos também devem ser consideradas prioritárias, pois naquela região existem garimpos diretamente sobre os filitos hematíticos.

Furos de sondagem podem permitir análises do filito em menor estado de alteração que possibilitariam análises geoquímicas mais confiáveis.

As idades U-Pb obtidas de três amostras de diferentes fácies de filitos hematíticos não corroboram com a separação de dois segmentos tectonoestratigráficos para o Espinhaço Meridional. Aparentemente, os filitos foram intrudidos em momentos de intensa subsidência mecânica ao longo das falhas profundas nas fases sin-rifte principais.

Os diques e corpos de rochas alcalinas sendo fontes sin-sedimentares para as fácies de conglomerados de leques aluviais e rios entrelaçados da Formação Sopa Brumadinho foram retrabalhados e mineralizaram as unidades sedimentares, o que explica a presença de diamantes nos metaconglomerados. 
Apesar dos baixos teores de diamantes, a exploração foi intensa na região facilitada pelo elevado grau de intemperismo das rochas, permitindo desagregá-las facilmente por desmonte hidráulico. Ao trabalhar com os metaconglomerados o mapeamento das diversas lentes e delimitação de suas geometrias torna-se um entrave, assim como o cálculo do teor, uma vez que o mesmo pode apresentar ampla oscilação entre as ocorrências. Em contrapartida, fonte primária possui teor mais uniforme, que pode ser estimado através de química mineral e amostragens de grande volume.

Os resultados do presente trabalho mostram a necessidade de aquisição de novas informações para corroborar as conclusões até então obtidas, incluindo:

- Intensificação das análises geoquímicas com o intuito de se otimizar a analogia entre as composições dos filitos hematíticos com os lamproítos e lamprófiros fanerozoicos;

- Ampliação dos estudos petrológicos com auxílio de microssonda eletrônica para entendimento da composição dos minerais acessórios com estrutura cristalina mais estável (ex.: espinélios);

- Refino dos estudos geocronológicas de zircões detríticos em matriz do metaconglomerado Sopa Brumadinho e em zircões de provável natureza magmática dos filitos hematíticos para auxiliar no entendimento da evolução do rifte na região do Espinhaço Meridional. 


\section{REFERÊNCIAS BIBLIOGRÁFICAS}

Almeida Abreu, P. A. 1989. Geologia das quadrículas Onça e Cuiabá (Gouveia- Mg), região mediana-central da Serra do Espinhaço Meridional. Dissertação de Mestrado, Instituto de Geociências, Universidade Federal do Rio de Janeiro, 75p.

Almeida Abreu, P. A. 1993. A evolução geodinâmica da Serra do Espinhaço Meridional, Minas Gerais, Brasil. Diss. Doutorado. Freiburg (Alemanha) Univ. Freiburg, Geol. Inst. 150p.

Almeida Abreu, P.A. 1995. O Supergrupo Espinhaço: O rifte, a bacia e o orógeno. Geonomos, 3: $1-18$.

Almeida Abreu P. A. 1996. O caminho das pedras. Geonomos, 4:77-93.

Almeida Abreu, P. A. \& Plug, R. 1992. Geodynamic evolution of the southern Serra do Espinhaço, Minas Gerais, Brazil. Part I: The Basin. In: geowissenchaftliches lateinamerikakolloquium, 13, Münster, 1992. Abstracts... Münster, Westfälische Wilhelms-Universität Münster (Alemanha)

Almeida Abreu, P. A. \& Renger, F. E. 2002. Serra do Espinhaço Meridional: um orógeno de colisão do Mesoproterozóico. Revista Brasileira de Geociências, São Paulo, v. 32, n. 1, p.1-14

Barbosa, O. 1951. Contribuição à origem do diamante em Diamantina, Estado de Minas Gerais, DNPM - Divisão de Geologia e Mineração, Rio de Janeiro, RJ, Brasil, 36 p.

Baron, L.M., Lishmun, S.R., Oakes, G.M., Barron, B.J. 1994. Subduction diamonds in New Soth Wales: Implications for exploration in eastern Australia. Geological Survey of New South Wales Quaterly Notes. 94:1-23.

Battilani G.A., Varajão A.F.D., Gomes N.S. 2000. Metamorphic degree variations in Proterozoic sandstones of the Tombador Formation, Bahia State, Brazil. Zbl Geol Paläont 1: 917-926.

Battilani, G.A., Gomes, N.S., Guerra, W.J. 2007. The occurrence of microdiamonds in Mesoproterozoic Chapada Diamantina intrusive rocks Bahia/Brazil. Anais da Academia Brasileira de Ciências 79 (2), 321-332.

Battilani, G.A., Vasconcelos, P.M., Gomes, N.S. \& Guerra, W.J. 2005. Geochronological data of dykes and sills intruding Proterozoic Sequences of the Tombador Formation, Bahia Brazil. In: Simpósio do Cráton do São Francisco, 3, Salvador, BA, Brazil, SBG Núcleo NE, p. 139-142

Brito Neves, B.B., Kawashita K., Cordani U.G., Delhal J. 1979. A evolução geocronológica da Cordilheira do Espinhaço; dados novos e integração. Rev. Bras. Geoc. 9:71-85.

Cabral A.R., Wiedenbeck M., Koglin N., Lehmann B., Abreu F.R. 2012. Boron-isotopic constraints on the petrogenesis of hematitic phyllite in the southern Serra do Espinhaço, Minas Gerais, Brazil. Lithos 140-141 (2012) 224-233.

Campos J.E.G \& Gonzaga G.M. 1999. O transporte de diamantes por sistemas fluviais a longas distâncias: uma visão crítica. RBG, v 29.

Chaves, M.L.S.C. 1987. Novas contribuições à geologia da região de Diamantina (MG). $4^{\circ}$ Simp. Geol. Mg. Belo Horizonte. 72-87,

Chaves M.L.S.C. 1997. Geologia e mineralogia do diamante da Serra do Espinhaço em Minas Gerais. IG/USP, São Paulo, Tese de Doutoramento, 289p. 
Chaves, M.L.S.C. \& Uhlein, A. 1991. Depósitos diamantíferos da região do Alto/Médio Rio Jequitinhonha, Minas Gerais. In: Schobbenhaus, C; Queiroz, E.T.; Coelho, C.E.S. (coords.). Principais depósitos minerais do Brasil. Brasília, DNPM. V.4-A.117-138.

Chaves, M.L.S.C. \& Meneghetti Filho, I. 2002. Conglomerado Diamantífero Sopa, Região de Diamantina, MG: marco histórico da mineração do diamante no Brasil. In: Schobbenhaus, Carlos; Campos, Diogenes de Almeida; Queiroz, Emanuel Teixeira; Winge, Manfredo; Berbert-Born, Mylène Luíza Cunha (Ed.). Sítios geológicos e paleontológicos do Brasil. 1. ed. Brasília: DNPM/CPRM/SIGEP. v. 1.

Chaves, M.L.S.C., Dossin, I.A., Uhlein, A., Alvarenga, C.J.S. 1985. Projeto Mapeamento Geológico do Espinhaço Meridional, Relatório da Quadrícula Sopa. Diamantina, Convênio DNPM-CPRM/ UFMG-Centro de Geologia Eschwege, 62p.

Chaves, M.L.S.C., Dupont, H., Karfunkel, J.\& Svisero, D.P. 1993. Depósitos diamantíferos de Minas Gerais: uma revisão. In: UFMT, Simpósio Brasileiro de Geologia do Diamante, 1, Cuiabá, Anais..., 1:79-100.

Chaves, M.L.S.C., Karfunkel, J. \& Svisero, D. P. 1998. Sobre a polêmica da origem do diamante na Serra do Espinhaço (Minas Gerais): Um enfoque mineralógico. Revista Brasileira de Geociências, 28(3) 285-294.

Chaves, M.L.S.C., Karfunkel, J., Hoppe, A., Hoover, D., P. 2001. Diamonds from Espinhaço Range (Minas Gerais, Brazil) and their redistribuition through the geologic record. Journal of South American Earth Sciences 14, 277-289.

Chemale Jr. F., Dussin I.A., Alkmim F.F., Martins M.S., Queiroga G. \& Santos M.N. 2012. Unravelling a Proterozoic basin history through detrital zircon geochronology: The case of the Espinhaço Supergroup, Minas Gerais, Brazil. Gondwana Research (in press)

Chemale Jr. F., Dussin I.A., Martins M., Santos M.N. 2011. Nova abordagem tectonoestratigráfica do Supergrupo Espinhaço em sua porção meridional (MG). Geonomos, 19(2), 173-41

Clement, C.R., E.M.W. Skinner, B.H. Scott-Smith. 1984. Kimberlite re-defined. Journal of Geology 32. 223-228

Correns, C.W. 1932. Über die Diamantenlagerstätten des Hochlandes von Diamantina, Minas Geraes, Brasilien. Zeitsch. Prakt. Geol., 10: 161 - 168, 177 - 181

Cullers, R.L. \& Berendsen, P. 2011. Mineralogical and Chemical Evolution of Lamproites in Woodson and Wilson Counties, Southeastern Kansas. Kansas Geological Survey, Technical Series 22.

Danderfer A. 2000. Geologia sedimentar e evolução tectônica do Espinhaço Setentrional, Estado da Bahia. Brasília, 494 p. (Tese de Doutoramento, IG-UnB).

Danderfer A., de Waele B., Pedreira A.J. \& Nalini H.A. 2009. New geochronological constraints on the geological evolution of Espinhaço basin within the São Francisco Craton-Brazil. Precambrian Research, 170: 116-128.

Dawson, J.B. 1967. A review of the geology of kimberlites. Ultramafic and Related Rocks. Edited by P.J. Wyllie. New York: Jonh Wiley. 241-251.

Derby, O.A. 1879. Observações sobre algumas rochas diamantíferas da Província de Minas Gerais. Archivos do Museu Nacional, 4:1 21-132.

Derby, O.A. 1882. Modes of occurrence of the diamond in Brazil. American Journal of Science, 24:34-42. 
Dossin I.A., Chaves M.L. de S.C., Uhlein A. \& Alvarenga C.J.S. 1985. Geologia e Depósitos Diamantíferos da Região de Sopa, Diamantina (MG)., III Simp.Geol. Minas Gerais, BH, Bol. 5: $276-290$.

Dossin I.A., Garcia A.J.V., Uhlein A., Dardenne M.A. \& Dossin T.M. 1987. Facies eólico na Formação Galho do Miguel, Supergrupo Espinhaço (MG). In: SBG, Simp. Sistem. Depos. Precamb., Ouro Preto, Anais, 85-96.

Dossin, I.A., Dossin, T. M., Charvet, J., Cocherie, A. \& Rossi, P., 1993. Single-Zircon dating by step-wise Pb-evaporation of Middle Proterozoic magmatism in the Espinhaço Range, southeastern São Francisco Craton (Minas gerais, Brazil). An. II Simp. Craton São Francisco, Salvador. 39-42.

Draper, D. 1905. Earliest discoveries of diamonds in Cape Colony and the Transvaal. South African Mines, Com. Ind., 2 (February 4th).1501.

Draper, D. 1920. The high level diamond-bearing breccias of Diamantina, Brazil. Transactions of the Geological Society of South Africa, 23:43-51.

Draper, D. 1923. Additional evidence regarding the origin of the high level diamond-bearing breccias of Diamantina, Brazil. Transactions of the Geological Society of South Africa, 26:7-12.

Dussin, I.A. \& Dussin, T.M. 1995. Supergrupo Espinhaço: modelo de evolução geodinâmica. Geonomos, 3:19-26.

Dussin, I.A. 1994. Evolution Structurale de la pertie méridional de L'Espinhaço sur la bordure orientale du Craton São Francisco. Minas Gerais - Brésil: Um exemple de tectonique protérozoique superposé. Universite d’Orleans, Orleans (Ph. D. Thesis, 200 pp.).

Erlich, E.I. \& Hausel, W.D. 2002. Diamond Deposits: origin, exploration and jistory of discovery. Littleton, CO:SME/AIME

Filemon, K.E. 2005. Caracterização dos diamantes da Província Kimberlítica de Juína (MT), e distritos diamantíferos de Espigão d'Oeste (RO), Cacoal (RO) e Diamantina (MG). Tese de Doutorado, Universidade Estadual Paulista, Campos Rio Claro.

Fleischer, R. 1995. Prospecção e economia do diamante da Serra do Espinhaço. Geonomos, 3: $27-30$.

Fogaça,A.C.C., Almeida Abreu,P.A. \& Schorscher,H.D. 1984. Estratigrafia da sequência supracrustal arqueana da porção mediana central da Serra do Espinhaço Meridional, Minas Gerais. XXXIII Cong. Br. Geol., Anais 6: 2654-2667.

Garcia, A.J.V. \& Uhlein, A. 1987. Sistemas deposicionais do Supergrupo Espinhaço na região de Diamantina (MG). In: SBG, Simpósio sobre Sistemas Deposicionais no PréCambriano, 1, Ouro Preto, Anais..., 1:113-135

Haralyi, N.L.E. \& Svisero, D.P. 1986. Geologia e análise estatística do diamante da Mina de Boa Vista. Diamantia- MG. In: Congresso Brasileiro de Geologia. Goiânia. SBG,v.6,p. 2297-2311.

Helmstaedt, H.H. 1993. Natural diamond occurrences and tectonic setting of primary diamond deposits. Diamonds: Exploration, Sampling and Evaluation; Proceedings of a Short Course, Prospectors and Developers Association of Canada, Toronto, Ont., Canada. 1-72

Herrgesell, G. 1984. Das Präkambrium am Ostrand der nördlichen Serra do Cipó (Serra do Espinhaço, Minas Gerais, Brasilien). Univ. Freigburg, Freiburg, Alemanha, Tese de Doutorado, 247 p. 
Janse, A.J.A. 1984. Is Clifford's rule still valid? Affimartive examples around the world. In: International Kimberlite Conference, 5, Araxá, 1991.CPRM Publication, v.2,215-235.

Jaques, A.L., Lewis, J.D. \& Smith, C.B. 1986. The kimberlites and lamproite of Western Australia. Geological Survey of Western Australia, Bulletin 132, 268p.

Karjunkel, J. \& Chaves, M. L. S. C. 1995. Conglomerados Cretácicos da Serra do Cabral, Minas Gerais: Um modelo para a redistribuição coluvio-aluvionar dos diamantes do Médio São Francisco. Geociências, 14.

Knauer, L.G. 1990. Evolução geológica do Precambriano da porção centro leste da Serra do Espinhaço Meridional e metalogênese associada. Dissertação de Mestrado, Campinas, UNICAMP, 298p.

Knauer, L.G. 2007. O Supergrupo Espinhaço em Minas Gerais: considerações sobre sua estratigrafia e seu arranjo estrutural. Geonomos, 15(1). 81-90.

Knauer, L.G. \& Schrank, A. 1993. A origem dos filitos hematíticos da Serra do Espinhaço Meridional, Minas Gerais. Geonomos, 1:33-38.

Köster, J. 1984. Geologie der nordwestlichen Serra Mineira südostlich von Buenópolis (Proterozoikum, Serra do Espinhaço, Minas Gerais, Brasilien). Univ. Freiburg, Freiburg, Alemanha, Diplomarbeit, 85 p

Machado, N., Schrank, A., Abreu, F.R., Knauer, L.G. \& Almeida Abreu, P.A. 1989. Resultados preliminares da geocronologia U/Pb na Serra do Espinhaço Meridional. In: SBG, Simp. Geol. Minas Gerais, 5, Belo Horizonte, Anais, 171-174.

Marshak, S. \& Alkmim, F.F. 1989. Proterozoic contraction :extension tectonics of the southern São Francisco region, Minas Gerais, Brazil. Tectonics 8, 555-571

Martins Neto, M.A. 1993. The sedimentary evolutiom of a Proterozoic rift basin: the basal Espinhaço Supergroup,southern Serra do Espinhaço, Minas Gerais, Brazil. Freiburg, Freiburger geowiss Beitr., 155 p. (Bd. 4).

Martins Neto, M.A. 1995b. Tectono-estratigrafia da Bacia Espinhaço no Estado de Minas Gerais. Boi Soe. Brás. Geol, Núcleo Minas Gerais, 13: 25-27.

Martins Neto, M.A. 1998. O Supergrupo Espinhaço em Minas Gerais: registro de uma bacia rifte-sag do Paleo/Mesoproterozóico. Rev. Bras. Geoc., 28:151-168.

Mitchell, R.H. 1970. Kimberlite and related rocks. A critical re-appraisal. Journal of Geology 78. p.686-704

Moraes, L.J. 1934. Depósitos diamantíferos no norte do Estado de Minas Gerais. Boletim DNPM/SFPM, 3:1-61.

Moraes, L.J. \& Guimarães, D. 1930. Geologia da região diamantífera do Norte de Minas Gerais - An. Acad. Bras. Cienc., 2: 153-186, Rio de Janeiro

Pereira, R.S. 2007. Cráton do São Franscisco, kimberlitos e diamantes. Tese Doutorado em Geologia-Universidade de Brasília, Brasília.

Pflug, R. 1965. A geologia da parte meridional da Serra do Espinhaço e zonas adjacentes, Minas Gerais. DNPM/ DGM, (Boletim 226). 55 p.

Pflug, R. 1967. Die Präkambrische Miogeosyncline der Espinhaço- Kordillere, Minas Gerais, Brasilien. Geol. Rundsch. 55:825-844.

Pflug, R. 1968. Observações sobre a estratigrafia da Série Minas na região de Diamantina, Minas Gerais. DNPM/DGM, 20 p. (Notas Prelim. Estudos 142). 
Pflug, R. \& Renger, F. 1973. Estratigrafia e evolução geológica da margem sudeste do Cráton Sanfranciscano. In: SBG, Congr. Bras. Geol., 27, Aracajú, Anais, 2:5-19.

Pix, J.D. \& Martius, C.F.P. 1828. Reise in Brasilien 1817-1820. München. Staatsbibliotek Universität München, V 1, 389 p.

Rock, N.M.S. (1991): Lamprophyres. Blackie, Glasgow, U.K

Schobbenhaus, C. 1993. O Proterozóico Médio no Brasil com ênfase à região Centro-Leste: Uma revisão. Univ.Freiburg, Freiburg, Alemanha, Tese de Doutorado, 155 p.

Schobbenhaus, C. \& Brito Neves, B.B. 2003. A geologia do Brasil no contexto da Plataforma Sul-Americana. In: L.A. Bizzi, R.M. Vidotti e J.H. Gonçalves (eds.). Geologia, Tectônica e Recursos Minerais do Brasil. Brasília: CPRM, Serviço Geológico do Brasil, 5-54.

Schobbenhaus, C. Hoppe, A., Baumann, A. \& Lork, A. 1994. Idade U/Pb do vulcanismo Rio dos Remédios, Chapada Diamantina, Bahia. In: SBG, Congr. Brasil. Geol., 38, Camboriú, Anais, 2:397-399.

Schöll, W.U. \& Fogaça, A.C.C. 1979. Estratigrafia da Serra do Espinhaço na região de Diamantina. In: SBG, Simp. Geol. Minas Gerais, 1, Diamantina, Atas, 55-73.

Schöll, W.U. \& Fogaça, A. C. C. 1981. Mapeamento Geológico das Quadículas de Guinda e Gouveia. Projeto Mapeamento do Espinhaço Meridional, DNPM/UFGM. Rel. Int, 51 pp, Diamantina, Mg.

Schrank, A., Dourado, B. C. \& Biondo, J. C. 1978. Estudo preliminar dos metavulcanitos do Grupo Macaúbas na região do Alto Jequitinhonha, Mg. XXX Congresso Brasileiro de Geologia, Recife. 1323-1335.

Scott-Smith, B.H. \& Skinner, E.M.V. 1984. A new look at Prairie Creek, Arkansas. In Developements in Petrology 11.A, kimberlites I., Kimberlites and Related Rocks, J. Kornprobst, (ed.). Elsevier Seismitic Publications, Amsterdam, p. 255-284.

Silva, R.R. 1995. Contribution to the stratigraphy of the lower Espinhaço Supergroup (Mesoproterozoic) between Diamantina and Gouveia, Minas Gerais, Brazil. Freiburg, Freiburger Geowiss., 115 p. (Beitr. 8).

Silva, R.R. 2013. Roteiro Geológico da Área de Diamantina, Minas Gerais: A rase rift da Bacia Proterozoica do Espinhaço, a partir do reconhecimento de discordâncias sedimentares. Geonomos, 21(1), 42-55.

Smith, C.B., 1983. Lead, strontium, and neodymium isotopic evidence for sources of African Cretaceous kimberlite, Nature, 304:51-54.

Soares Filho, B., Pinheiro, S.F. \& Costa, M. N. S. 1986. Contribuição ao estudo da Geologia de Conceição do Mato Dentro, MG. Metamig, Rel. Int, Belo Horizonte, MG. 14 p.

Uhlein, A. 1982. Geologia e Mineralizações de Cromita e Itabiritos da Região de Serro, Minas Gerais. UnB, Dissertação de Mestrado, Brasília, 198p.

Uhlein, A. 1991. Transição cráton - faixa dobrada: exemplo do Cráton do São Francisco e da Faixa Araçuaí (Ciclo Brasiliano) no Estado de Minas Gerais. Aspectos estratigráficos e estruturais. Inst. Geociências, Universidade de São Paulo, São Paulo, Tese de Doutorado, 295p.

Uhlein, A., Trompette, R. \& Egydio Silva, M.E. 1995. Rifteamentos superpostos e tectônica de inversão da borda sudeste do Cráton do São Francisco. Geonomos, 3(1): 99-107.

Wagner, P.A. 1928. The evidence of kimberlite pipes on the constitution of the outer part of theearth S. Af. 25, 127-148 
ANEXO I - Análises de microssonda da matriz dos filitos hematíticos.

\begin{tabular}{|c|c|c|c|c|c|c|c|c|c|c|c|c|c|c|c|c|}
\hline & $\mathrm{Na} 2 \mathrm{O}$ & $\mathrm{MgO}$ & $\mathrm{F}$ & $\mathrm{Al} 2 \mathrm{O} 3$ & $\mathrm{SiO} 2$ & $\mathrm{~K} 2 \mathrm{O}$ & $\mathrm{Cl}$ & $\mathrm{CaO}$ & $\mathrm{TiO} 2$ & $\mathrm{MnO}$ & $\mathrm{Cr} 2 \mathrm{O} 3$ & $\mathrm{FeO}$ & V2O3 & $(\mathrm{OH})$ & Total & Mineral \\
\hline Brumadinho & 0,323 & 1,787 & 0 & 31,119 & 47,401 & 10,575 & 0 & 0 & 0,269 & 0,08 & 0,066 & 3,857 & 0,054 & 4,47 & 100,001 & Fengita \\
\hline Brumadinho & 0,311 & 1,976 & 0 & 29,688 & 47,642 & 10,906 & 0,007 & 0 & 0,405 & 0,171 & 0 & 4,709 & 0,066 & 4,122 & 100,001 & Fengita \\
\hline Brumadinho & 0,266 & 2,067 & 0 & 30,255 & 47,513 & 10,925 & 0 & 0,023 & 0,153 & 0,074 & 0 & 4,341 & 0,063 & 4,32 & 100 & Fengita \\
\hline Brumadinho & 2,183 & 8,296 & 0 & 32,001 & 39,121 & 1,081 & 0,012 & 0,22 & 0,158 & 0,407 & 0,002 & 6,337 & 0,097 & 10,085 & 99,997 & Richeterita \\
\hline Brumadinho II & 0,029 & 0,04 & 0 & 5,477 & 0,061 & 0,01 & 0,286 & 1,268 & 0 & 0 & 0,053 & 1,558 & 0 & 91,282 & 99,999 & - \\
\hline Brumadinho II & 0,159 & 2,696 & 0 & 27,185 & 47,394 & 10,22 & 0,008 & 0,022 & 0,62 & 0,087 & 0,026 & 5,289 & 0,047 & 6,249 & 100 & Fengita \\
\hline Brumadinho II & 1,98 & 9,051 & 0,161 & 33,401 & 37,293 & 0,034 & 0,018 & 1,626 & 1,259 & 0,016 & 0,147 & 4,919 & 0,109 & 10,057 & 99,999 & Richeterita \\
\hline Caldeirões & 0,126 & 0,051 & 1,693 & 32,89 & 3,557 & 0,822 & 0,036 & 1,926 & 0,081 & 0 & 0,094 & 1,14 & 0 & 58,309 & 100,004 & - \\
\hline Caldeirões & 0,326 & 1,02 & 0 & 31,917 & 47,44 & 10,594 & 0 & 0,014 & 0,199 & 0,043 & 0,013 & 3,909 & 0,06 & 4,466 & 100,001 & Fengita \\
\hline Caldeirões & 0,334 & 1,108 & 0 & 31,698 & 46,016 & 10,708 & 0,035 & 0 & 0,364 & 0 & 0 & 4,58 & 0,035 & 5,13 & 100 & Fengita \\
\hline Caldeirões (Clorita) & 0,006 & 0 & 0 & 0 & 101,362 & 0,002 & 0,004 & 0,029 & 0,019 & 0,036 & 0 & 0,255 & 0 & 0 & 101,712 & Quartzo \\
\hline Caldeirões (Clorita) & 0,031 & 0 & 0 & 0 & 101,072 & 0,016 & 0 & 0 & 0,242 & 0 & 0,013 & 0,483 & 0 & 0 & 101,857 & Quartzo \\
\hline Caldeirões (Clorita) & 0,029 & 0,001 & 0 & 0,005 & 101,12 & 0,032 & 0 & 0,035 & 0 & 0,025 & 0 & 0,234 & 0,02 & 0 & 101,501 & Quartzo \\
\hline Caldeirões (Clorita) & 0 & 0,019 & 0 & 0,087 & 101,502 & 0 & 0,016 & 0 & 0,168 & 0,086 & 0,012 & 0,403 & 0,021 & 0 & 102,31 & Quartzo \\
\hline Caldeirões (Clorita) & 0,082 & 12,54 & 0,175 & 17,255 & 38,723 & 6,711 & 0,041 & 0,03 & 2,418 & 0,16 & 0 & 15,891 & 0,145 & 5,912 & 100 & Flogopita \\
\hline Caldeirões (Clorita) & 0,085 & 12,713 & 0,325 & 16,668 & 37,886 & 7,679 & 0,03 & 0,011 & 2,22 & 0,171 & 0,015 & 15,358 & 0,196 & 6,788 & 100,001 & Flogopita \\
\hline Caldeirões (Clorita) & 0,02 & 17,748 & 0 & 20,785 & 28,654 & 0,088 & 0,047 & 0 & 0,099 & 0,196 & 0,051 & 19,692 & 0,049 & 12,581 & 99,999 & Clorita \\
\hline Caldeirões (Clorita) & 0,02 & 18,185 & 0 & 21,138 & 28,054 & 0,045 & 0,009 & 0,062 & 0,314 & 0,117 & 0 & 20,042 & 0,076 & 11,94 & 100 & Clorita \\
\hline Caldeirões (Clorita) & 0 & 18,21 & 0 & 21,637 & 27,341 & 0,1 & 0 & 0 & 0,083 & 0,194 & 0 & 20,107 & 0,122 & 12,205 & 99,999 & Clorita \\
\hline Caldeirões (Clorita) & 0,001 & 19,537 & 0,018 & 20,62 & 26,604 & 0,041 & 0 & 0,003 & 0,01 & 0,244 & 0,038 & 20,136 & 0,068 & 12,687 & 99,999 & Clorita \\
\hline Caldeirões (Clorita) & 0,005 & 19,64 & 0 & 22,114 & 28,081 & 0,138 & 0,034 & 0,073 & 0,034 & 0,261 & 0,05 & 20,036 & 0,074 & 9,469 & 100,001 & Clorita \\
\hline Campo Sampaio & 0,169 & 3,073 & 0 & 26,053 & 48,203 & 10,754 & 0,063 & 0 & 0,747 & 0 & 0 & 5,726 & 0,012 & 5,213 & 99,999 & Fengita \\
\hline Campo Sampaio & 0,1 & 3,117 & 0 & 26,339 & 48,792 & 10,768 & 0,004 & 0 & 0,629 & 0 & 0,093 & 5,826 & 0,077 & 4,259 & 100,003 & Fengita \\
\hline Campo Sampaio & 0,191 & 2,871 & 0 & 26,003 & 46,941 & 10,773 & 0,016 & 0 & 0,973 & 0,041 & 0,025 & 5,716 & 0,044 & 6,408 & 99,998 & Fengita \\
\hline Campo Sampaio & 0,131 & 3,175 & 0 & 25,865 & 48,616 & 10,896 & 0,012 & 0,027 & 0,688 & 0,03 & 0,014 & 5,559 & 0,022 & 4,969 & 100,001 & Fengita \\
\hline Campo Sampaio & 0,116 & 2,926 & 0 & 27,014 & 47,79 & 10,896 & 0,013 & 0,021 & 0,966 & 0,067 & 0 & 5,522 & 0,023 & 4,648 & 99,999 & Fengita \\
\hline Macacos II & 0,138 & 2,636 & 0 & 26,508 & 46,653 & 10,576 & 0,056 & 0 & 0,461 & 0,033 & 0,026 & 4,746 & 0,007 & 8,172 & 99,999 & Fengita \\
\hline Macacos II & 0,158 & 2,798 & 0 & 27,982 & 48,668 & 10,684 & 0,001 & 0,02 & 0,586 & 0,06 & 0,027 & 4,857 & 0,057 & 4,102 & 100 & Fengita \\
\hline Macacos II & 0,183 & 1,8 & 0 & 29,775 & 46,898 & 10,978 & 0,007 & 0,055 & 0,439 & 0,026 & 0,053 & 4,453 & 0 & 5,337 & 100,002 & Fengita \\
\hline
\end{tabular}




\begin{tabular}{|c|c|c|c|c|c|c|c|c|c|c|c|c|c|c|c|c|}
\hline & $\mathrm{Na} 2 \mathrm{O}$ & $\mathrm{MgO}$ & $F$ & $\mathrm{Al} 2 \mathrm{O} 3$ & $\mathrm{SiO} 2$ & $\mathrm{~K} 2 \mathrm{O}$ & $\mathrm{Cl}$ & $\mathrm{CaO}$ & TiO2 & $\mathrm{MnO}$ & $\mathrm{Cr} 2 \mathrm{O} 3$ & $\mathrm{FeO}$ & V2O3 & $(\mathrm{OH})$ & Total & Mineral \\
\hline Macacos II & 0,2 & 2,087 & 0 & 29,489 & 47,17 & 11,044 & 0,017 & 0,084 & 0,277 & 0,051 & 0 & 5,094 & 0 & 4,493 & 100,002 & Fengita \\
\hline Macacos II & 0,144 & 1,994 & 0 & 29,593 & 47,589 & 11,073 & 0 & 0,011 & 0,537 & 0,086 & 0 & 4,408 & 0,008 & 4,558 & 100,001 & Fengita \\
\hline Macacos II & 0,178 & 1,82 & 0 & 30,254 & 47,064 & 11,163 & 0,012 & 0 & 0,538 & 0,006 & 0 & 4,546 & 0 & 4,422 & 100 & Fengita \\
\hline Macacos II & 0,156 & 1,725 & 0 & 30,12 & 47,047 & 11,222 & 0 & 0 & 0,795 & 0,003 & 0,026 & 4,623 & 0 & 4,282 & 99,999 & Fengita \\
\hline Macacos II & 1,988 & 5,998 & 0 & 34,999 & 38,084 & 0 & 0 & 0,376 & 0,591 & 0,13 & 0,12 & 7,152 & 0,103 & 10,458 & 99,999 & Richeterita \\
\hline Macacos II & 2,535 & 6,205 & 0 & 31,44 & 37,875 & 0,031 & 0,017 & 0,277 & 0,522 & 0,064 & 0 & 10,681 & 0,018 & 10,339 & 100 & Richeterita \\
\hline Macacos II & 2,363 & 6,513 & 0 & 31,285 & 37,197 & 0,037 & 0 & 0,261 & 2,056 & 0,112 & 0,04 & 9,681 & 0,059 & 10,396 & 100 & Richeterita \\
\hline Macacos II & 2,499 & 6,692 & 0 & 31,512 & 37,434 & 0,041 & 0,018 & 0,381 & 0,438 & 0,035 & 0 & 10,459 & 0,025 & 10,471 & 100,001 & Richeterita \\
\hline Macacos II & 2,401 & 6,929 & 0 & 31,918 & 37,137 & 0,016 & 0 & 0,273 & 0,275 & 0,073 & 0,014 & 9,87 & 0,006 & 11,089 & 100,001 & Richeterita \\
\hline Macacos II & 1,959 & 7,238 & 0,082 & 34,449 & 37,157 & 0,048 & 0,003 & 0,863 & 0,839 & 0,062 & 0,066 & 6,591 & 0,1 & 10,579 & 100 & Richeterita \\
\hline Macacos II & 2,826 & 10,046 & 0 & 31,487 & 38,907 & 0,117 & 0 & 0,17 & 0,453 & 0,175 & 0 & 5,974 & 0,038 & 9,807 & 100 & Richeterita \\
\hline Sopa & 0,033 & 0,053 & 0 & 66,673 & 4,318 & 0,152 & 0,013 & 0,009 & 0 & 0,033 & 0,028 & 0,282 & 0 & 28,41 & 100,001 & - \\
\hline Sopa & 0,075 & 0,128 & 0 & 37,685 & 47,952 & 1,155 & 0,026 & 0 & 0 & 0,038 & 0 & 0,944 & 0,013 & 11,989 & 99,999 & - \\
\hline Sopa & 0,446 & 1,132 & 0 & 31,985 & 47,956 & 10,386 & 0,006 & 0,01 & 0,363 & 0,078 & 0 & 3,443 & 0,044 & 4,15 & 99,998 & Fengita \\
\hline Sopa & 0,454 & 1,438 & 0 & 30,957 & 47,581 & 10,485 & 0,003 & 0,067 & 0,444 & 0,091 & 0 & 3,978 & 0,01 & 4,494 & 100,001 & Fengita \\
\hline Sopa & 0,472 & 1,496 & 0 & 31,623 & 47,319 & 10,629 & 0 & 0 & 0,379 & 0 & 0,038 & 3,724 & 0,022 & 4,298 & 100 & Fengita \\
\hline Sopa & 0,376 & 1,464 & 0 & 31,588 & 47,455 & 10,679 & 0,017 & 0 & 0,456 & 0,037 & 0 & 3,911 & 0,024 & 3,996 & 99,999 & Fengita \\
\hline Sopa & 0,443 & 1,261 & 0 & 31,491 & 47,062 & 10,819 & 0,042 & 0,022 & 0,288 & 0,025 & 0,038 & 4,33 & 0,051 & 4,137 & 100 & Fengita \\
\hline
\end{tabular}


ANEXO II - Análises de microssonda de óxidos dos filitos hematíticos.

\begin{tabular}{|c|c|c|c|c|c|c|c|c|c|c|c|c|c|c|c|c|}
\hline & $\mathrm{Na} 2 \mathrm{O}$ & $\mathrm{MgO}$ & $\mathrm{F}$ & $\mathrm{Al} 2 \mathrm{O} 3$ & $\mathrm{SiO} 2$ & $\mathrm{~K} 2 \mathrm{O}$ & $\mathrm{Cl}$ & $\mathrm{CaO}$ & $\mathrm{TiO} 2$ & $\mathrm{MnO}$ & Cr2O3 & $\mathrm{FeO}$ & V2O3 & $(\mathrm{OH})$ & Total & Mineral \\
\hline Brumadinho & 0,02 & 0,03 & 0,20 & 0,95 & 1,29 & 0,33 & 0,00 & 0,01 & 40,71 & 0,18 & 0,02 & 48,06 & 0,34 & 7,96 & 100,00 & Titano Hematita \\
\hline Brumadinho & 0,06 & 0,15 & 0,30 & 4,34 & 4,15 & 0,96 & 0,03 & 0,02 & 2,08 & 0,13 & 0,02 & 84,42 & 0,09 & 3,38 & 100,00 & Titano Hematita \\
\hline Brumadinho & 0,00 & 0,11 & 0,36 & 1,11 & 1,65 & 0,33 & 0,02 & 0,00 & 2,38 & 0,20 & 0,02 & 90,57 & 0,13 & 3,28 & 100,00 & Titano Hematita \\
\hline Brumadinho & 0,06 & 0,09 & 0,31 & 0,79 & 1,15 & 0,21 & 0,00 & 0,00 & 2,78 & 0,05 & 0,00 & 92,80 & 0,08 & 1,82 & 100,00 & Titano Hematita \\
\hline Brumadinho & 0,00 & 0,01 & 0,30 & 0,21 & 0,25 & 0,23 & 0,00 & 0,00 & 2,73 & 0,21 & 0,00 & 92,95 & 0,10 & 3,15 & 100,00 & Titano Hematita \\
\hline Brumadinho & 0,04 & 0,02 & 0,35 & 0,39 & 0,59 & 0,11 & 0,01 & 0,00 & 2,49 & 0,03 & 0,06 & 93,32 & 0,08 & 2,66 & 100,00 & Titano Hematita \\
\hline Brumadinho & 0,01 & 0,02 & 0,33 & 0,17 & 0,26 & 0,13 & 0,00 & 0,00 & 2,59 & 0,11 & 0,00 & 93,42 & 0,08 & 3,03 & 100,00 & Titano Hematita \\
\hline Brumadinho & 0,00 & 0,02 & 0,35 & 0,09 & 0,12 & 0,04 & 0,00 & 0,00 & 3,16 & 0,23 & 0,00 & 94,10 & 0,07 & 1,96 & 100,00 & Titano Hematita \\
\hline Brumadinho & 0,00 & 0,00 & 0,29 & 0,10 & 0,10 & 0,01 & 0,00 & 0,01 & 2,70 & 0,11 & 0,00 & 94,20 & 0,09 & 2,52 & 100,00 & Titano Hematita \\
\hline Brumadinho & 0,03 & 0,04 & 0,35 & 0,05 & 0,09 & 0,04 & 0,00 & 0,03 & 2,17 & 0,12 & 0,04 & 95,17 & 0,14 & 1,88 & 100,00 & Titano Hematita \\
\hline Brumadinho II & 0,014 & 0 & 0,296 & 0,035 & 0,111 & 0 & 0,004 & 0,011 & 2,394 & 0,087 & 0,02 & 92,234 & 0,053 & 4,867 & 100 & Titano Hematita \\
\hline Caldeirões (Clorita) & 0 & 0,002 & 0,131 & 0,959 & 30,872 & 0,002 & 0,004 & 28,548 & 38,205 & 0 & 0,009 & 0,519 & 0,511 & 0,293 & 100,001 & Titanita \\
\hline Caldeirões (Clorita) & 0 & 0,07 & 0 & 0,037 & 0,052 & 0 & 0 & 0,009 & 97,851 & 0 & 0,01 & 0,771 & 1,061 & 0,14 & 99,997 & Rutilo \\
\hline Caldeirões (Clorita) & 0 & 0,004 & 0 & 0,263 & 0,397 & 0,006 & 0,002 & 0,047 & 97,142 & 0 & 0,042 & 0,775 & 1,139 & 0,185 & 100 & Rutilo \\
\hline Caldeirões (Clorita) & 0,019 & 0,01 & 0 & 0,047 & 0,065 & 0 & 0 & 0 & 99,902 & 0 & 0,008 & 0,79 & 1,111 & 0 & 99,999 & Rutilo \\
\hline Caldeirões (Clorita) & 0 & 0,042 & 0 & 0,046 & 0,19 & 0,006 & 0 & 0 & 98,017 & 0 & 0,041 & 0,942 & 1,115 & 0 & 100,002 & Rutilo \\
\hline Caldeirões (Clorita) & 0,02 & 0,02 & 0 & 0,641 & 0,592 & 0,001 & 0,001 & 0,049 & 93,934 & 0,005 & 0,052 & 2,429 & 1,338 & 0,917 & 101,952 & Rutilo \\
\hline Caldeirões (Clorita) & 0,007 & 0,174 & 0 & 1,403 & 1,256 & 0,006 & 0 & 0,179 & 90,306 & 0,023 & 0 & 2,513 & 1,16 & 2,974 & 100,001 & Rutilo \\
\hline Caldeirões (Clorita) & 0,03 & 0,094 & 0,027 & 2,422 & 0,836 & 0,037 & 0,01 & 0,071 & 79,106 & 0,107 & 0 & 12,383 & 1,042 & 3,848 & 100,002 & Rutilo \\
\hline Caldeirões (Clorita) & 0,008 & 0,009 & 0 & 0,026 & 0,177 & 0,007 & 0,017 & 0,024 & 81,311 & 0,048 & 0,026 & 16,05 & 0,81 & 1,49 & 100,002 & Rutilo \\
\hline Caldeirões (Clorita) & 0,027 & 0,237 & 0,012 & 3,192 & 0,853 & 0,022 & 0 & 0,067 & 61,045 & 0,031 & 0 & 23,768 & 0,9 & 9,853 & 100,002 & Ilmenita \\
\hline Caldeirões (Clorita) & 0 & 0,013 & 0,087 & 0,04 & 2,234 & 0,022 & 0,005 & 0 & 66,236 & 0,651 & 0,048 & 29,503 & 0,584 & 0,616 & 99,999 & Ilmenita \\
\hline Caldeirões (Clorita) & 0 & 0,066 & 0,19 & 4,432 & 0,383 & 0,013 & 0,036 & 0,03 & 47,644 & 0 & 0,016 & 34,782 & 0,674 & 11,819 & 100,001 & Ilmenita \\
\hline Caldeirões (Clorita) & 0 & 0,041 & 0 & 0 & 0,222 & 0 & 0,026 & 0 & 59,241 & 1,419 & 0,016 & 35,774 & 0,526 & 2,741 & 99,999 & Ilmenita \\
\hline Caldeirões (Clorita) & 0 & 0,039 & 0 & 0,095 & 0,28 & 0 & 0 & 0 & 55,774 & 2,91 & 0,08 & 36,653 & 0,523 & 3,648 & 101,049 & Ilmenita \\
\hline Caldeirões (Clorita) & 0,046 & 0,168 & 0,247 & 6,345 & 1,544 & 0,128 & 0,01 & 0,062 & 44,418 & 0,027 & 0,049 & 37,346 & 0,702 & 9,014 & 100 & Ilmenita \\
\hline Caldeirões (Clorita) & 0,047 & 0,09 & 0 & 1,609 & 1,466 & 0,015 & 0 & 0,009 & 52,293 & 2,251 & 0,031 & 37,774 & 0,482 & 3,933 & 100,002 & Ilmenita \\
\hline Caldeirões (Clorita) & 0 & 2,627 & 0,242 & 11,377 & 4,454 & 0,022 & 0 & 0,017 & 3,969 & 0,05 & 0,059 & 62,75 & 0,383 & 14,154 & 100,399 & Titano Hematita \\
\hline Caldeirões (Clorita) & 0 & 0,048 & 0,307 & 0,064 & 0,104 & 0 & 0 & 0,007 & 28,823 & 0,065 & 0 & 69,768 & 0,289 & 0,656 & 100 & Titano Hematita \\
\hline
\end{tabular}




\begin{tabular}{|c|c|c|c|c|c|c|c|c|c|c|c|c|c|c|c|c|}
\hline & $\mathrm{Na} 2 \mathrm{O}$ & $\mathrm{MgO}$ & $\mathrm{F}$ & $\mathrm{Al} 2 \mathrm{O} 3$ & $\mathrm{SiO} 2$ & $\mathrm{~K} 2 \mathrm{O}$ & $\mathrm{Cl}$ & $\mathrm{CaO}$ & $\mathrm{TiO} 2$ & $\mathrm{MnO}$ & $\mathrm{Cr} 2 \mathrm{O} 3$ & $\mathrm{FeO}$ & V2O3 & $(\mathrm{OH})$ & Total & Mineral \\
\hline Caldeirões I (Magnetita) & 0,045 & 0,01 & 0,28 & 0,163 & 0,158 & 0,142 & 0,013 & 0,011 & 6,876 & 0,182 & 0,115 & 89,823 & 0,144 & 2,157 & 100 & Titano Hematita \\
\hline Caldeirões I (Magnetita) & 0,02 & 0,055 & 0,383 & 0,513 & 0,679 & 0,177 & 0 & 0,02 & 5,12 & 0,138 & 0,08 & 90 & 0,139 & 2,839 & 100 & Titano Hematita \\
\hline Caldeirões I (Magnetita) & 0 & 0,035 & 0,357 & 0,125 & 0,161 & 0,035 & 0 & 0,036 & 5,994 & 0,195 & 0 & 90,34 & 0,095 & 2,777 & 100,15 & Titano Hematita \\
\hline Caldeirões I (Magnetita) & 0,07 & 0 & 0,264 & 0,155 & 0,14 & 0,135 & 0 & 0,034 & 3,461 & 0,112 & 0,11 & 92,124 & 0,119 & 3,386 & 99,998 & Titano Hematita \\
\hline Caldeirões I (Magnetita) & 0,037 & 0,01 & 0,363 & 0,152 & 0,046 & 0,014 & 0,003 & 0,035 & 0,088 & 0,098 & 0,064 & 94,829 & 0,092 & 4,324 & 100 & Titano Hematita \\
\hline Caldeirões I (Magnetita) & 0,007 & 0 & 0,248 & 0,17 & 0,174 & 0,012 & 0,008 & 0 & 0,091 & 0,078 & 0,019 & 95,066 & 0,104 & 4,129 & 99,999 & Titano Hematita \\
\hline Campo Sampaio & 0,042 & 0,009 & 0,217 & 0,152 & 0,132 & 0,05 & 0,022 & 0 & 8,368 & 0,049 & 0 & 85,059 & 0,086 & 5,909 & 100,002 & Titano Hematita \\
\hline Campo Sampaio & 0 & 0 & 0,308 & 0,145 & 0,142 & 0,065 & 0,013 & 0,017 & 8,135 & 0,016 & 0,039 & 88,098 & 0,107 & 3,045 & 99,999 & Titano Hematita \\
\hline Campo Sampaio & 0,007 & 0,054 & 0,328 & 0,138 & 0,123 & 0,088 & 0 & 0,063 & 3,954 & 0,038 & 0 & 89,544 & 0,056 & 5,747 & 100 & Titano Hematita \\
\hline Campo Sampaio & 0,046 & 0 & 0,256 & 0,031 & 0,079 & 0 & 0 & 0 & 3,404 & 0,058 & 0 & 92,614 & 0,065 & 3,555 & 100,108 & Titano Hematita \\
\hline Macacos II & 0,014 & 0 & 0,333 & 0,028 & 0,051 & 0,016 & 0,001 & 0 & 8,469 & 0,05 & 0 & 88,751 & 0,077 & 2,353 & 99,999 & Titano Hematita \\
\hline Macacos II & 0,036 & 0,015 & 0,258 & 0,083 & 0,074 & 0,018 & 0,011 & 0,066 & 7,066 & 0 & 0 & 90,417 & 0,066 & 2 & 100,11 & Titano Hematita \\
\hline Macacos II & 0 & 0,029 & 0,298 & 0,056 & 0,056 & 0,02 & 0 & 0 & 5,861 & 0 & 0,012 & 91,032 & 0,066 & 2,697 & 100 & Titano Hematita \\
\hline Macacos II & 0,002 & 0,002 & 0,25 & 0,241 & 0,454 & 0,081 & 0 & 0 & 5,3 & 0 & 0,014 & 91,426 & 0,099 & 2,236 & 100 & Titano Hematita \\
\hline Macacos II & 0 & 0,007 & 0,304 & 0,06 & 0,038 & 0 & 0 & 0,02 & 5,236 & 0,019 & 0 & 91,894 & 0,051 & 2,499 & 100,002 & Titano Hematita \\
\hline Macacos II & 0 & 0,023 & 0,301 & 0,011 & 0,058 & 0 & 0,02 & 0,016 & 5,227 & 0 & 0 & 91,94 & 0,067 & 2,468 & 100,001 & Titano Hematita \\
\hline Macacos II & 0,017 & 0,037 & 0,359 & 0,024 & 0,004 & 0,015 & 0,011 & 0,004 & 4,609 & 0 & 0,052 & 92,256 & 0,058 & 2,708 & 100,003 & Titano Hematita \\
\hline Macacos II & 0 & 0 & 0,304 & 0,036 & 0,001 & 0 & 0 & 0,012 & 5,1 & 0,027 & 0 & 92,406 & 0,058 & 2,184 & 99,999 & Titano Hematita \\
\hline Sopa (Gir) & 0,003 & 0 & 0 & 0,012 & 0,063 & 0,011 & 0,003 & 0,02 & 99,711 & 0 & 0,009 & 1,842 & 0,825 & 0 & 100 & Rutilo \\
\hline Sopa (Gir) & 0,015 & 0,014 & 0 & 0,026 & 0,086 & 0,092 & 0 & 0 & 80,596 & 0,039 & 0 & 20,636 & 0,653 & 0 & 100 & Rutilo \\
\hline Sopa (Gir) & 0,011 & 0,007 & 0,194 & 0,087 & 0,192 & 0,055 & 0,04 & 0,029 & 34,712 & 0,02 & 0 & 61,996 & 0,298 & 2,449 & 102,498 & Titano Hematita \\
\hline Sopa (Gir) & 0 & 1,436 & 0,195 & 1,351 & 1,474 & 0,01 & 0,004 & 0 & 24,973 & 0,126 & 0,021 & 66,692 & 0,244 & 3,557 & 100,003 & Titano Hematita \\
\hline Sopa (Gir) & 0,002 & 0,014 & 0,228 & 0,028 & 0,228 & 0,023 & 0,027 & 0,028 & 17,916 & 0,13 & 0,001 & 78,428 & 0,244 & 2,805 & 100 & Titano Hematita \\
\hline Sopa (Gir) & 0,003 & 0,014 & 0,183 & 0,186 & 0,206 & 0,044 & 0,002 & 0 & 16,124 & 0,136 & 0 & 80,635 & 0,192 & 2,355 & 99,999 & Titano Hematita \\
\hline Sopa (Gir) & 0,003 & 0 & 0,348 & 0,084 & 0,108 & 0,02 & 0,007 & 0,054 & 6,763 & 0,095 & 0 & 89,804 & 0,054 & 2,807 & 100,147 & Titano Hematita \\
\hline Sopa (Gir) & 0 & 0 & 0,283 & 0,054 & 0,057 & 0,001 & 0,009 & 0,017 & 6,444 & 0,132 & 0,046 & 90,919 & 0,11 & 2,048 & 100 & Titano Hematita \\
\hline Sopa (Gir) & 0 & 0 & 0,323 & 0,083 & 0,08 & 0,034 & 0,024 & 0,012 & 4,858 & 0,134 & 0 & 92,198 & 0,077 & 2,318 & 99,999 & Titano Hematita \\
\hline Sopa (Gir) & 0,025 & 0,008 & 0,286 & 0,04 & 0,05 & 0,062 & 0,135 & 0 & 3,142 & 0,027 & 0 & 92,669 & 0,105 & 3,6 & 100,001 & Titano Hematita \\
\hline Sopa (Gir) & 0,049 & 0,042 & 0,277 & 0,117 & 0,409 & 0,14 & 0,104 & 0,065 & 1,815 & 0,154 & 0 & 93,753 & 0,092 & 3,124 & 99,999 & Titano Hematita \\
\hline Sopa (Gir) & 0,017 & 0 & 0,291 & 0,067 & 1,253 & 0,018 & 0,01 & 0,011 & 1,902 & 0,106 & 0,114 & 94,226 & 0,099 & 2,011 & 99,999 & Titano Hematita \\
\hline
\end{tabular}




\begin{tabular}{|c|c|c|c|c|c|c|c|c|c|c|c|c|c|c|c|c|}
\hline Sopa (Gir) & 0 & 0,004 & 0,319 & 0,083 & 0,089 & 0,049 & 0 & 0 & 2,346 & 0,182 & 0 & 94,431 & 0,149 & 2,481 & 99,999 & Titano Hematita \\
\hline Sopa (Gir) & 0,008 & 0,03 & 0,334 & 0,089 & 0,061 & 0,024 & 0,002 & 0 & 2,435 & 0 & 0 & 94,628 & 0,108 & 2,421 & 99,998 & Titano Hematita \\
\hline Sopa (Gir) & 0 & 0,05 & 0,323 & 0,084 & 0,063 & 0,022 & 0,004 & 0 & 1,827 & 0,187 & 0,059 & 94,864 & 0,074 & 2,579 & 102,157 & Titano Hematita \\
\hline Sopa (Gir) & 0,024 & 0 & 0,219 & 0,091 & 0,028 & 0,01 & 0,018 & 0 & 2,377 & 0,054 & 0,018 & 95,001 & 0,107 & 2,15 & 99,999 & Titano Hematita \\
\hline Sopa (Gir) & 0,008 & 0,011 & 0,357 & 0,112 & 0,077 & 0,106 & 0 & 0 & 1,501 & 0,132 & 0,014 & 95,129 & 0,065 & 2,639 & 100,001 & Titano Hematita \\
\hline
\end{tabular}


ANEXO III - Resultados Diafratometria de Raio X.
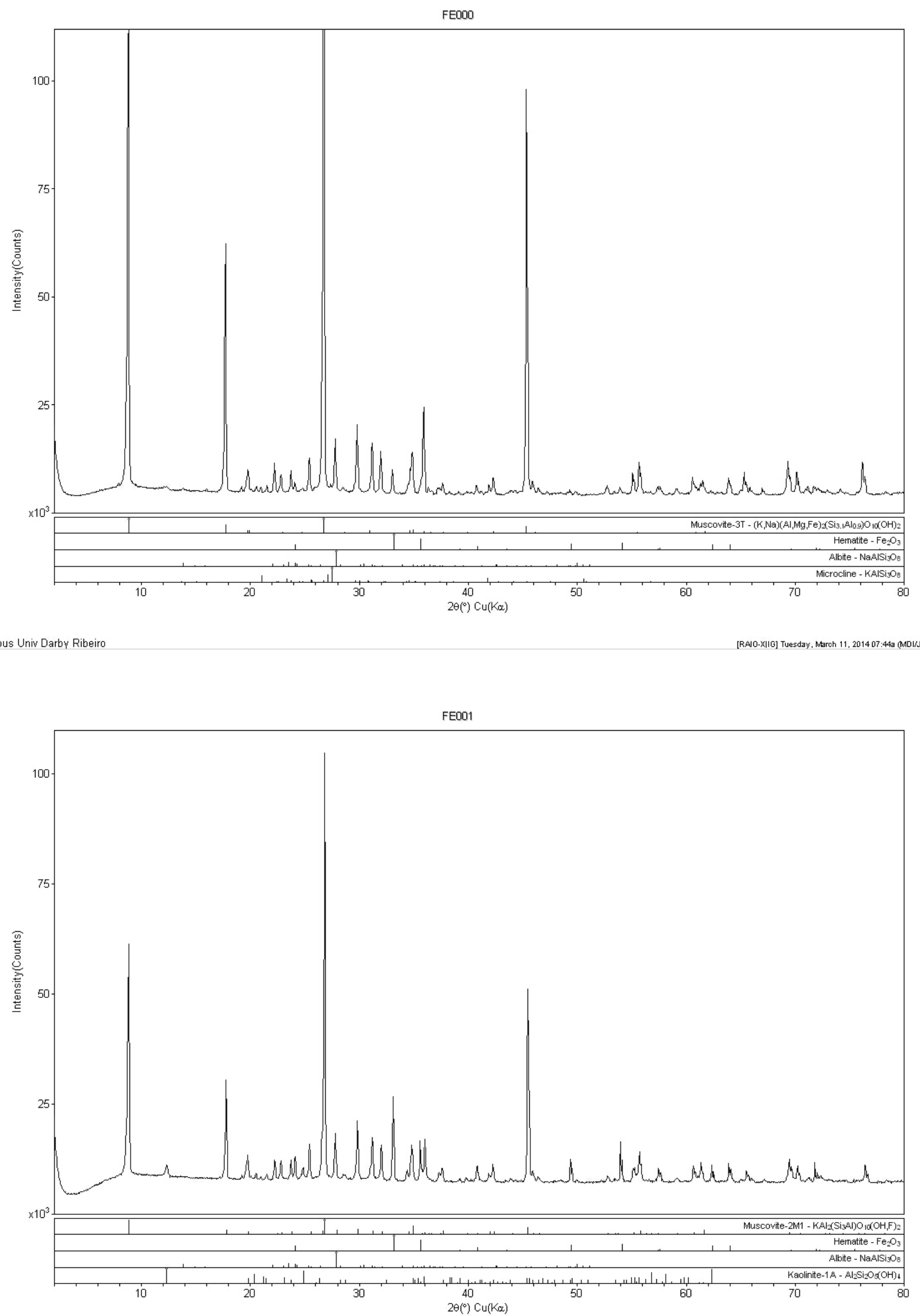


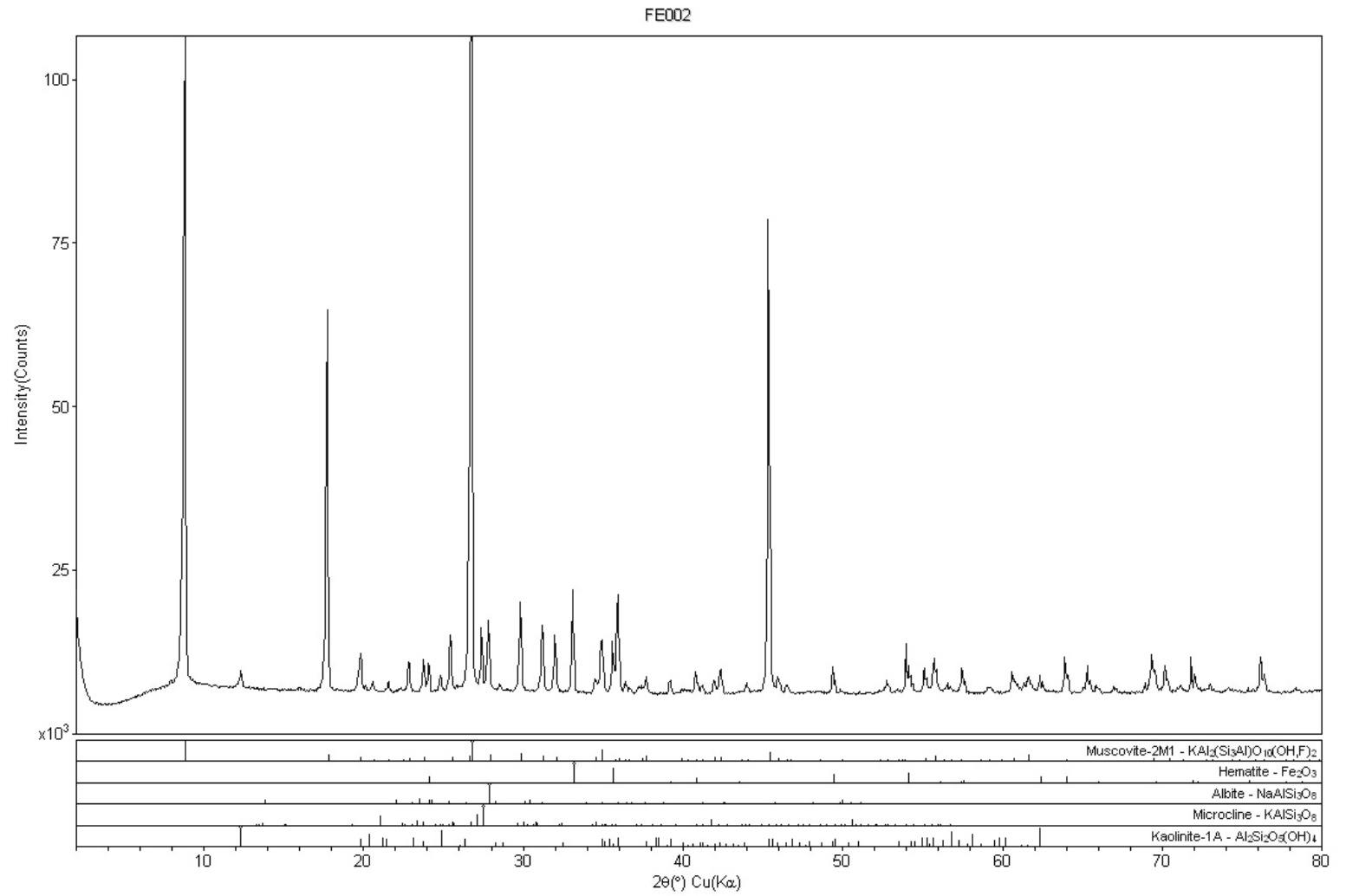

Campus Univ Darby Ribeiro

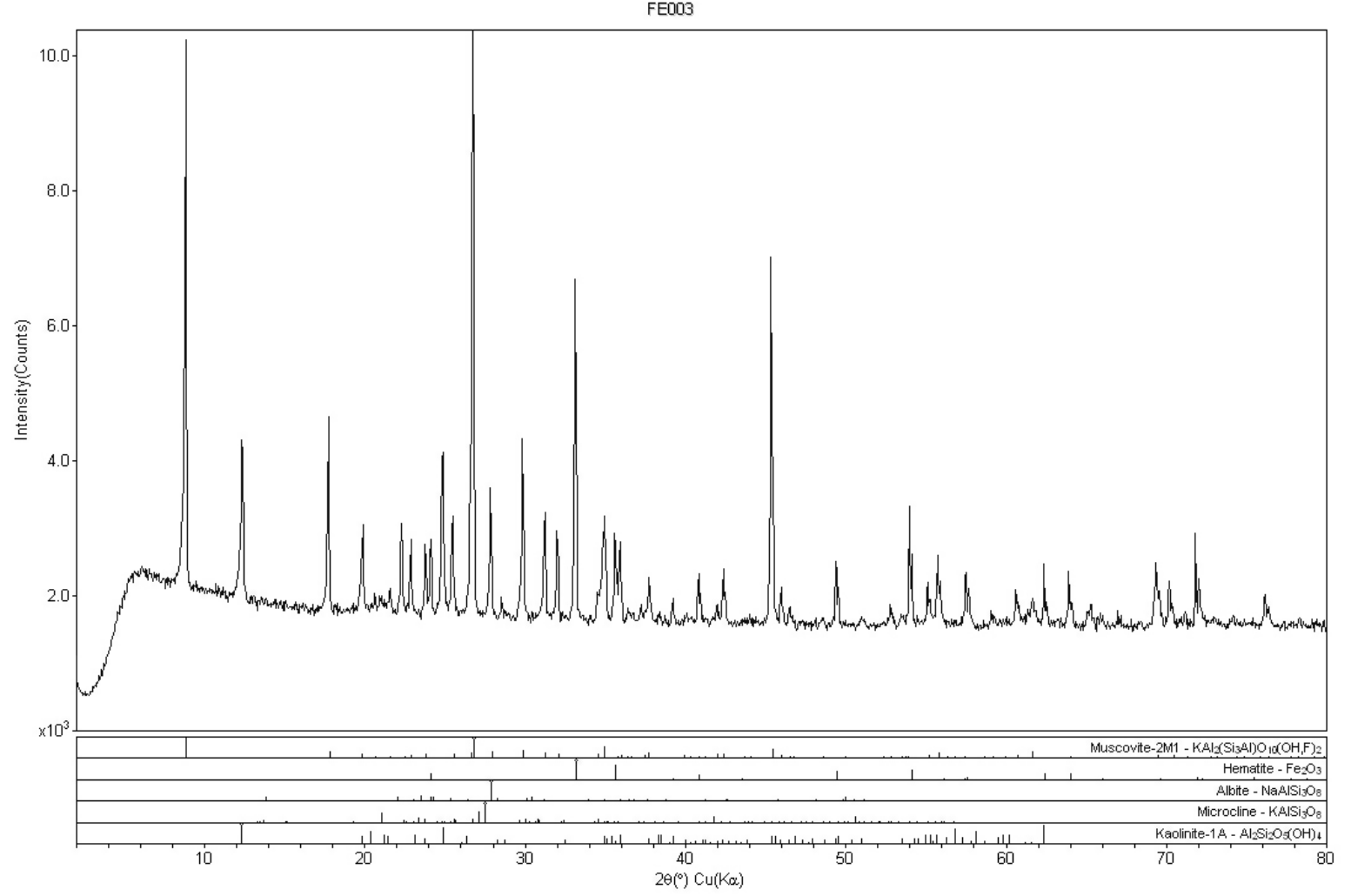




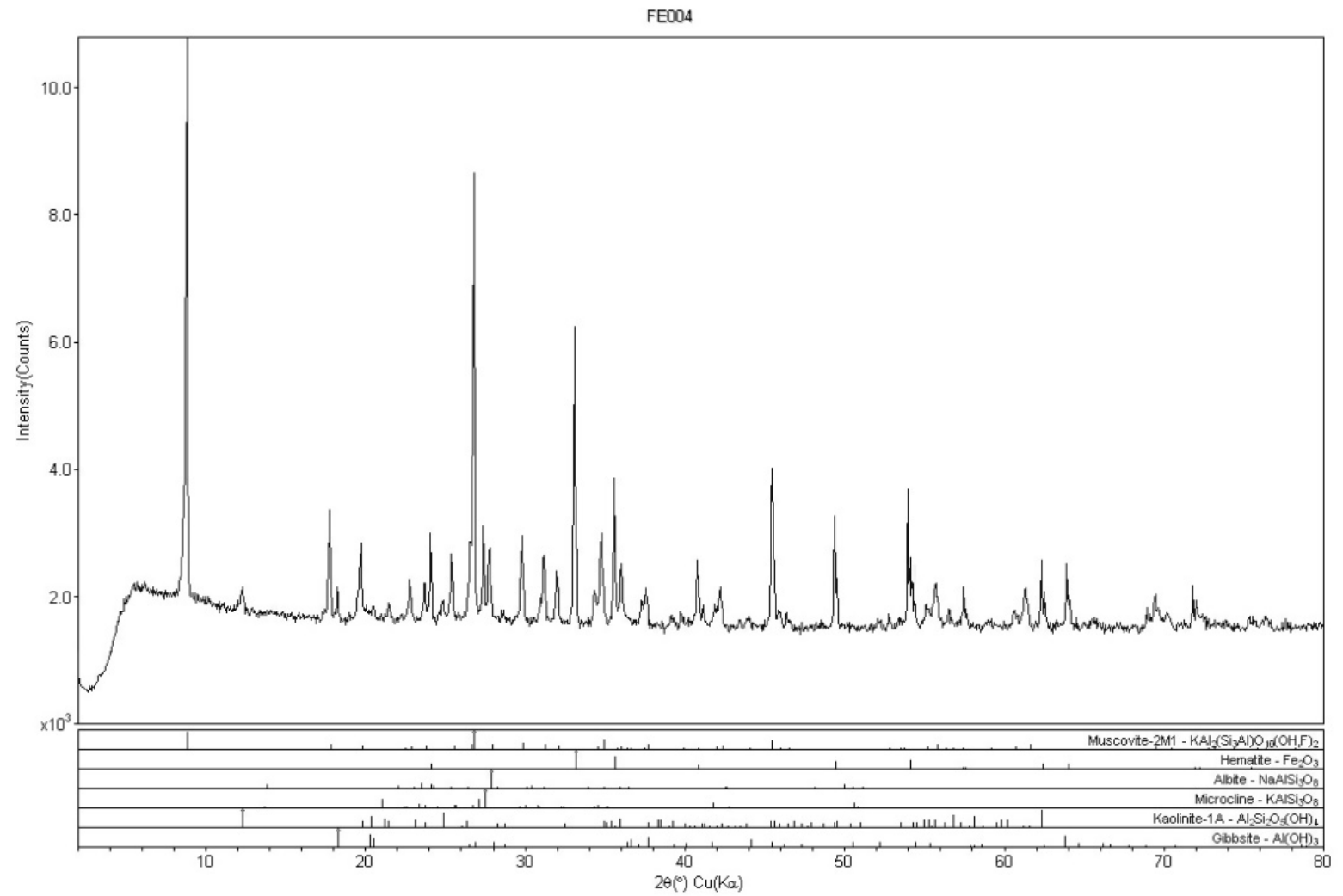

Campus Univ Darby Ribeiro 
ANEXO IV - Resultados Geocronológicos

Datações Filito Hematítico Lavra Brumadinho

\begin{tabular}{|c|c|c|c|c|c|c|}
\hline & & Ages $^{5}$ & & & & \\
\hline${ }^{207} \mathrm{~Pb} /{ }^{206} \mathrm{~Pb}$ & $2 \sigma$ abs & ${ }^{206} \mathrm{~Pb} /\left.\right|^{238} \mathrm{U}$ & $2 \sigma$ abs & ${ }^{207} \mathrm{~Pb} /{ }^{235} \mathrm{U}$ & $2 \sigma a b s$ & $\%$ U-Pb disc ${ }^{4}$ \\
\hline 1642 & 60 & 1759 & 30 & 1706 & 32 & $-7,14$ \\
\hline 1664 & 57 & 1807 & 49 & 1741 & 37 & $-8,60$ \\
\hline 1690 & 72 & 1826 & 53 & 1763 & 43 & $-8,07$ \\
\hline 1736 & 60 & 1678 & 51 & 1704 & 40 & 3,30 \\
\hline 1736 & 42 & 1753 & 35 & 1745 & 27 & $-0,98$ \\
\hline 1748 & 32 & 1754 & 32 & 1751 & 23 & $-0,37$ \\
\hline 1749 & 17 & 1746 & 24 & 1747 & 16 & 0,15 \\
\hline 1948 & 65 & 1830 & 47 & 1886 & 41 & 6,05 \\
\hline 2107 & 21 & 2243 & 45 & 2173 & 25 & $-6,43$ \\
\hline 2124 & 23 & 2140 & 32 & 2132 & 21 & $-0,76$ \\
\hline 2132 & 30 & 2112 & 41 & 2122 & 26 & 0,93 \\
\hline 2137 & 17 & 2131 & 25 & 2134 & 16 & 0,24 \\
\hline 2138 & 27 & 2082 & 41 & 2110 & 25 & 2,61 \\
\hline 2150 & 17 & 2154 & 30 & 2152 & 18 & $-0,17$ \\
\hline 2164 & 18 & 2156 & 30 & 2160 & 18 & 0,37 \\
\hline 2180 & 152 & 2014 & 79 & 2097 & 88 & 7,62 \\
\hline 2201 & 20 & 2152 & 31 & 2177 & 19 & 2,21 \\
\hline 2632 & 20 & 2680 & 46 & 2653 & 24 & $-1,81$ \\
\hline 2691 & 28 & 2644 & 45 & 2670 & 26 & 1,75 \\
\hline 2704 & 15 & 2779 & 39 & 2736 & 20 & $-2,77$ \\
\hline 2927 & 18 & 2481 & 73 & 2734 & 36 & 15,22 \\
\hline 2973 & 28 & 2964 & 139 & 2970 & 59 & 0,31 \\
\hline 3025 & 36 & 2893 & 58 & 2972 & 33 & 4,35 \\
\hline
\end{tabular}


Datações Filito Hematítico Lavra Eminosa

\begin{tabular}{|c|c|c|c|c|c|c|}
\hline & & $\begin{array}{c}\text { Ages }^{5} \\
\text { 206 }\end{array}$ & & & & \\
\hline${ }^{207} \mathrm{~Pb} /{ }^{206} \mathrm{~Pb}$ & $2 \sigma \mathrm{abs}$ & ${ }^{206} \mathrm{~Pb} /{ }^{238} \mathrm{U}$ & $2 \sigma$ abs & $\left.{ }^{207} \mathrm{~Pb}\right|^{235} \mathrm{U}$ & $2 \sigma \mathrm{abs}$ & $\%$ U-Pb disc ${ }^{4}$ \\
\hline 1736 & 36 & 1733 & 35 & 1734 & 26 & 0,15 \\
\hline 2016 & 100 & 2484 & 137 & 2236 & 78 & $-23,23$ \\
\hline 2096 & 18 & 2266 & 50 & 2178 & 26 & $-8,14$ \\
\hline 2131 & 16 & 2182 & 29 & 2156 & 17 & $-2,37$ \\
\hline 2139 & 16 & 2150 & 25 & 2145 & 16 & $-0,53$ \\
\hline 2141 & 28 & 2243 & 53 & 2190 & 30 & $-4,77$ \\
\hline 2144 & 14 & 2092 & 24 & 2119 & 15 & 2,45 \\
\hline 2149 & 25 & 2134 & 32 & 2142 & 21 & 0,71 \\
\hline 2152 & 14 & 2136 & 34 & 2144 & 19 & 0,75 \\
\hline 2154 & 16 & 1984 & 34 & 2068 & 20 & 7,87 \\
\hline 2163 & 29 & 2252 & 39 & 2206 & 25 & $-4,11$ \\
\hline 2175 & 27 & 2028 & 36 & 2102 & 24 & 6,76 \\
\hline 2188 & 14 & 2208 & 30 & 2198 & 17 & $-0,91$ \\
\hline 2194 & 126 & 2243 & 33 & 2218 & 68 & $-2,26$ \\
\hline 2197 & 21 & 2187 & 40 & 2192 & 23 & 0,43 \\
\hline 2198 & 15 & 2179 & 22 & 2189 & 15 & 0,88 \\
\hline 2203 & 13 & 2260 & 26 & 2230 & 15 & $-2,57$ \\
\hline 2212 & 19 & 2085 & 33 & 2150 & 20 & 5,75 \\
\hline 2648 & 25 & 2940 & 49 & 2770 & 25 & $-11,01$ \\
\hline 2725 & 36 & 479 & 66 & 1116 & 96 & 82,42 \\
\hline 2733 & 17 & 2693 & 24 & 2716 & 16 & 1,44 \\
\hline 2922 & 146 & 1524 & 164 & 2208 & 133 & 47,86 \\
\hline
\end{tabular}


Datações Filito Hematítico Lavra Campo Sampaio

\begin{tabular}{|c|c|c|c|c|c|c|}
\hline & & Ages $^{5}$ & & & & \\
\hline${ }^{207} \mathrm{~Pb} /{ }^{206} \mathrm{~Pb}$ & $2 \sigma$ abs & ${ }^{206} \mathrm{~Pb} /{ }^{238} \mathrm{U}$ & $2 \sigma a b s$ & ${ }^{207} \mathrm{~Pb} /{ }^{235} \mathrm{U}$ & $2 \sigma a b s$ & $\%$ U-Pb disc ${ }^{4}$ \\
\hline 2655 & 17 & 2782 & 68 & 2709 & 31 & $-4,81$ \\
\hline 1708 & 33 & 1890 & 58 & 1805 & 34 & $-10,68$ \\
\hline 2128 & 105 & 2041 & 33 & 2085 & 56 & 4,07 \\
\hline 2261 & 22 & 2155 & 79 & 2210 & 41 & 4,72 \\
\hline 2117 & 24 & 2146 & 35 & 2131 & 22 & $-1,39$ \\
\hline 2121 & 22 & 2172 & 26 & 2146 & 18 & $-2,40$ \\
\hline 2127 & 22 & 2224 & 34 & 2174 & 21 & $-4,55$ \\
\hline 2066 & 40 & 2056 & 30 & 2061 & 26 & 0,52 \\
\hline 2189 & 21 & 2263 & 28 & 2224 & 18 & $-3,38$ \\
\hline 2100 & 28 & 2121 & 32 & 2111 & 22 & $-0,99$ \\
\hline 2142 & 32 & 2045 & 34 & 2094 & 25 & 4,56 \\
\hline 2133 & 31 & 1893 & 101 & 2010 & 56 & 11,23 \\
\hline 2121 & 75 & 2241 & 100 & 2179 & 61 & $-5,65$ \\
\hline 2413 & 31 & 2453 & 39 & 2431 & 25 & $-1,65$ \\
\hline 2200 & 51 & 2186 & 67 & 2194 & 42 & 0,66 \\
\hline 2128 & 63 & 2150 & 78 & 2139 & 50 & $-1,02$ \\
\hline
\end{tabular}

